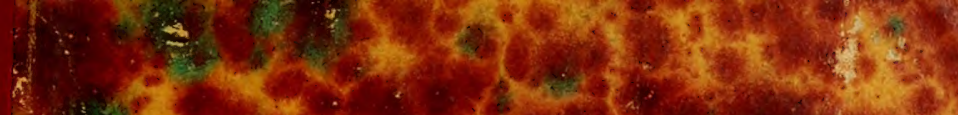

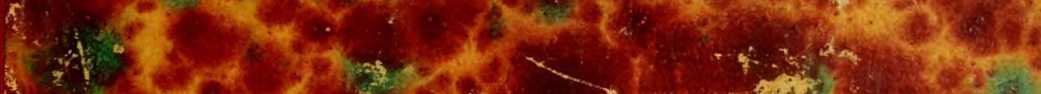

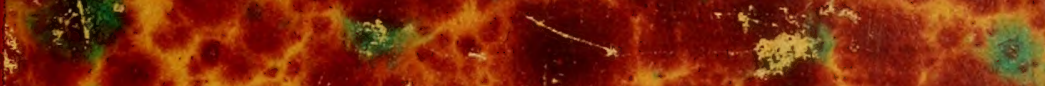

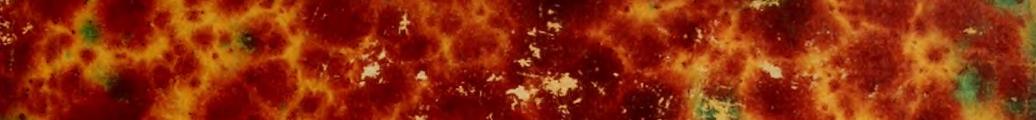

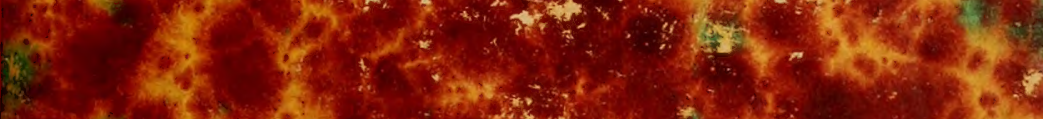

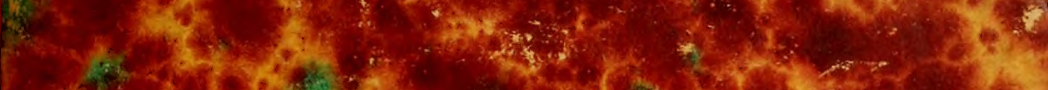
$\therefore$ (1) (3)

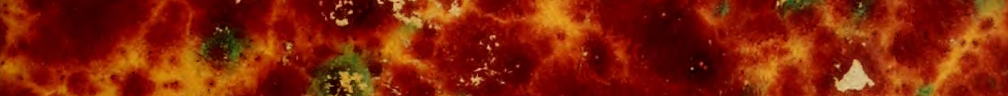

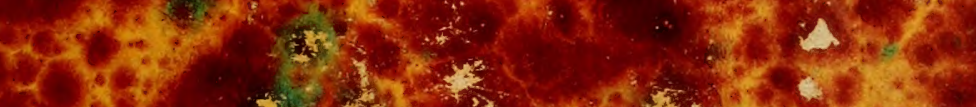

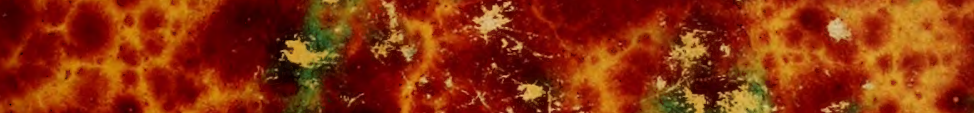

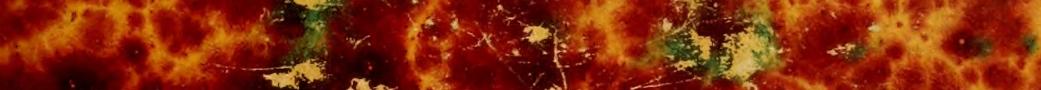
siter (1) 34 s. (4)

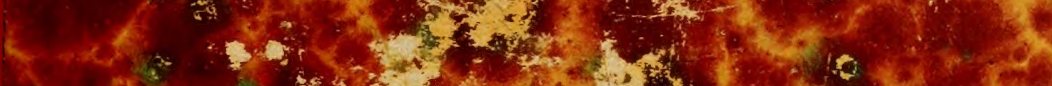

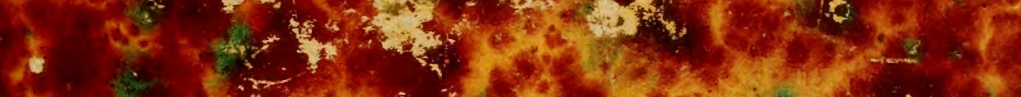

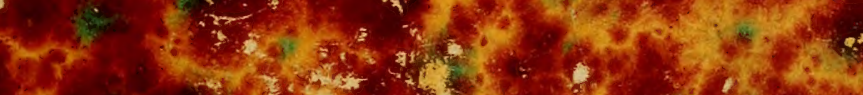

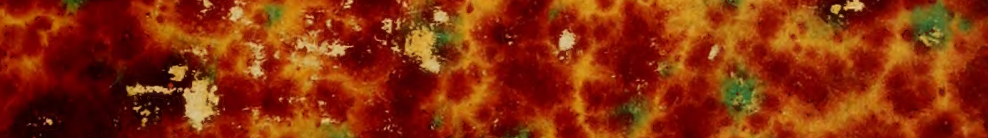

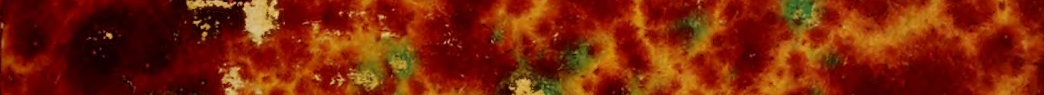

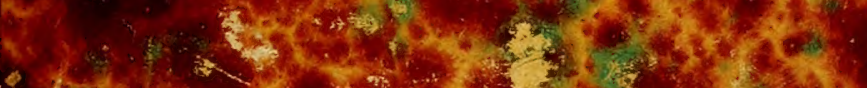

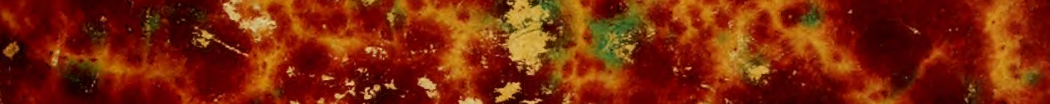

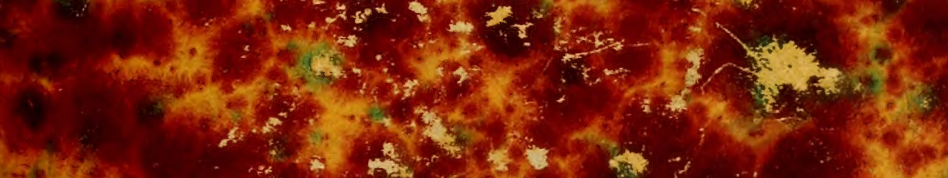

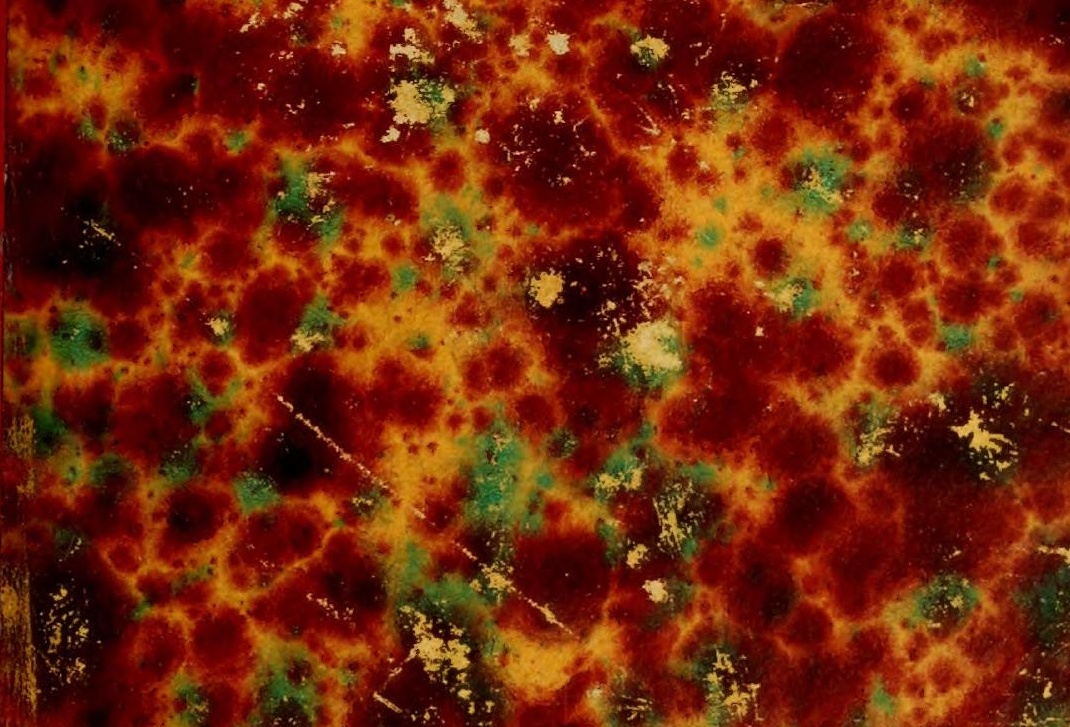




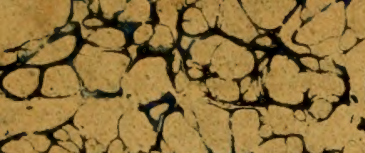

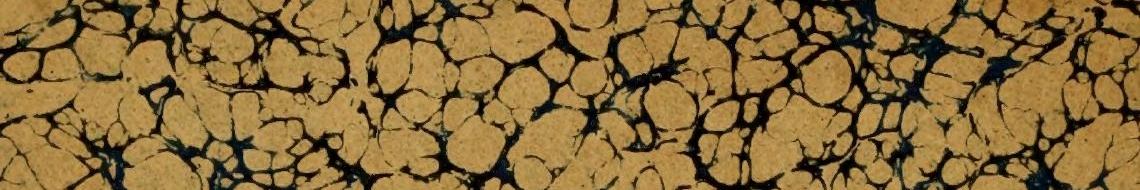

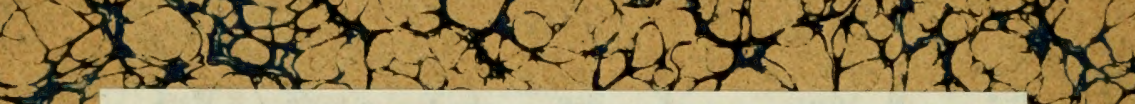
5

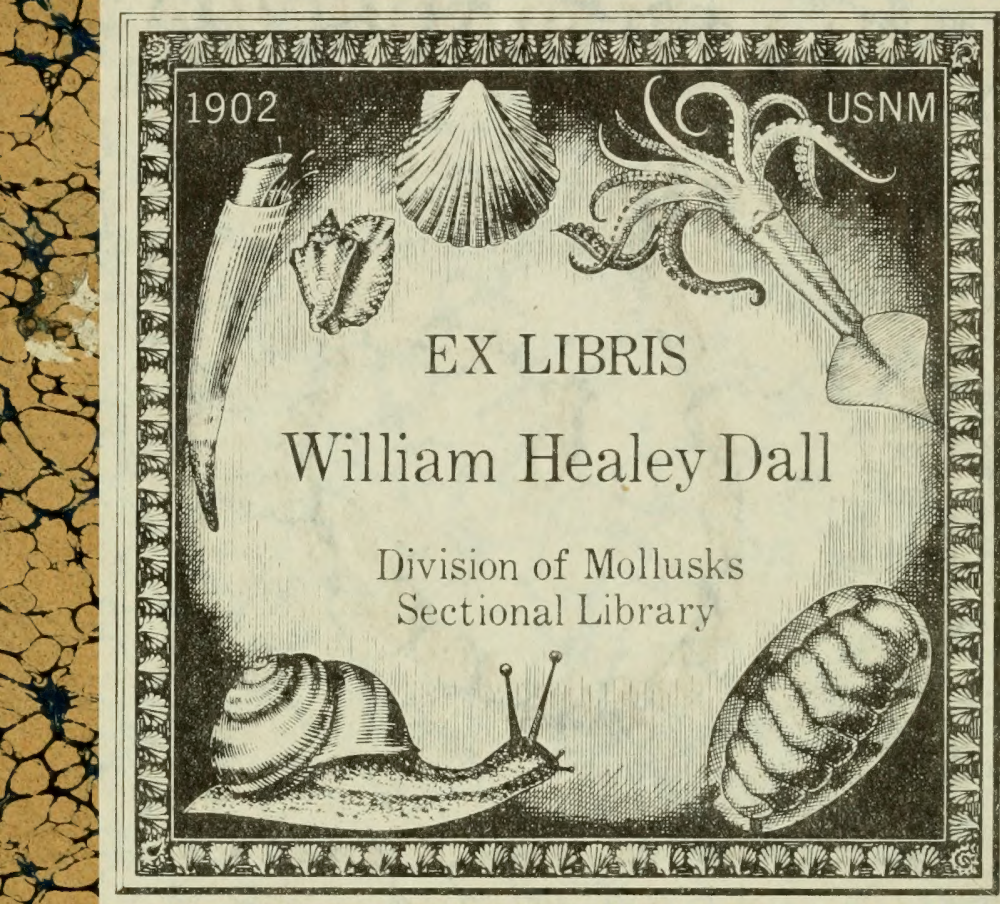
if

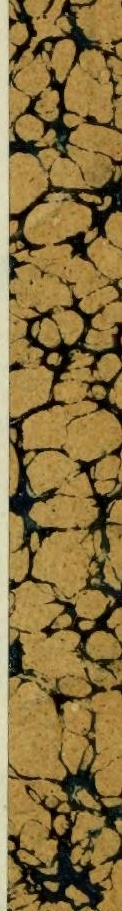

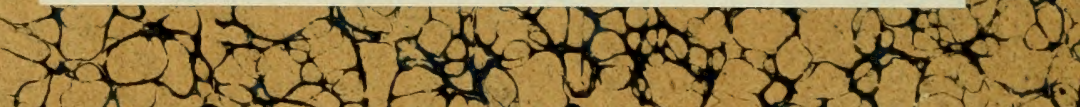

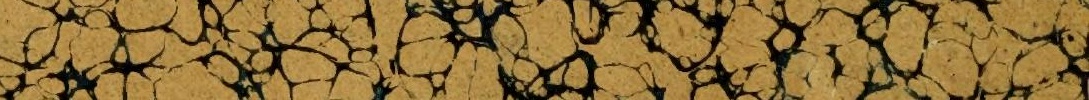

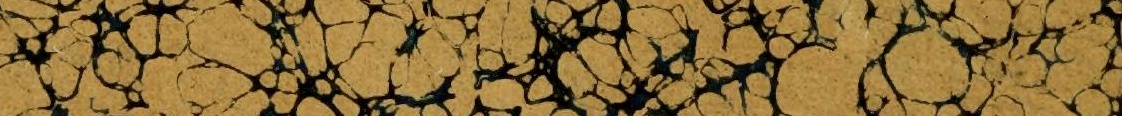

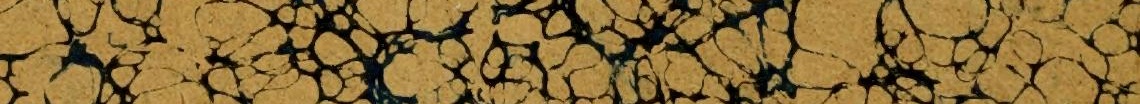

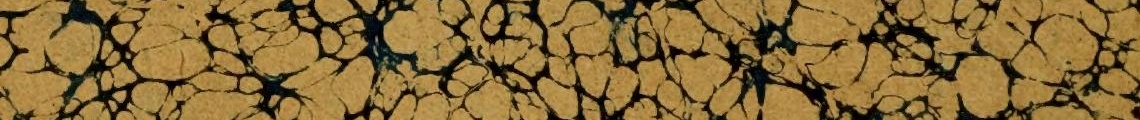

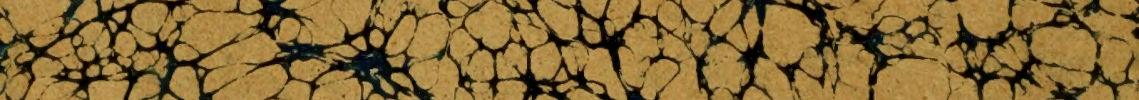

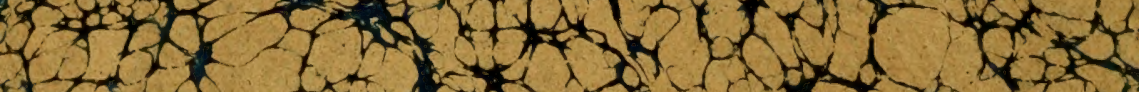

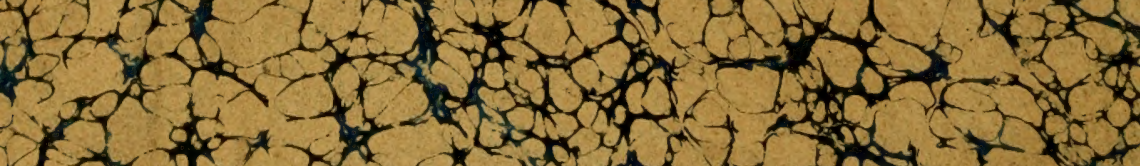

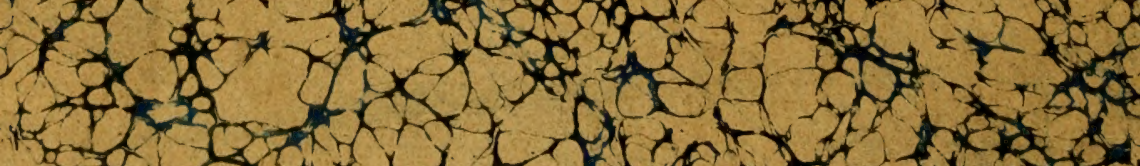
15.

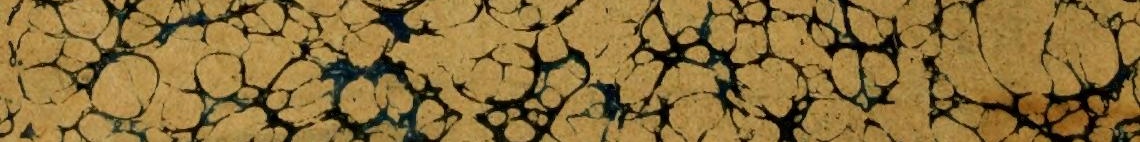


L Ju

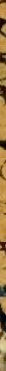

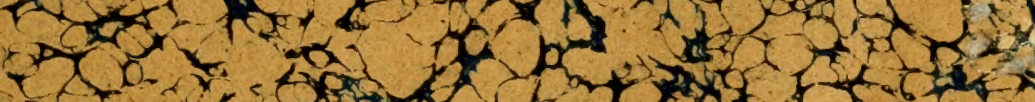

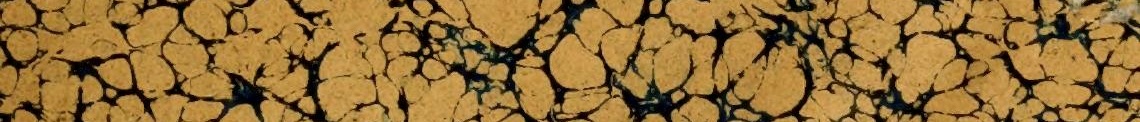

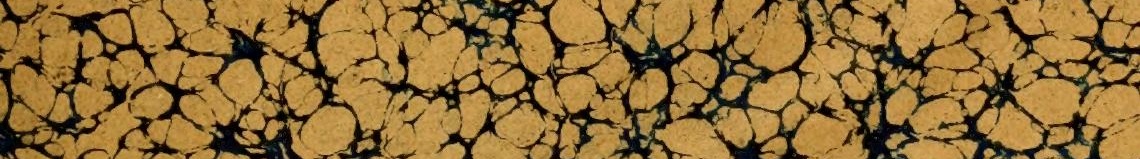

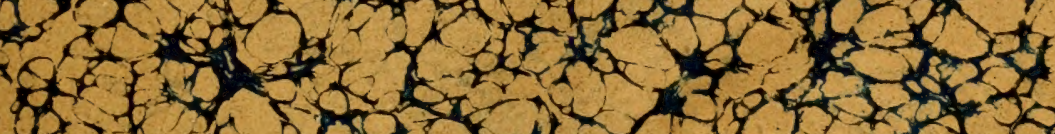

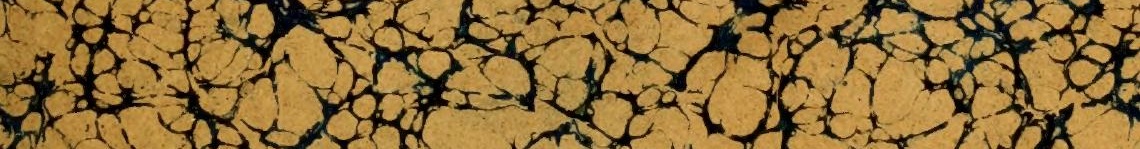

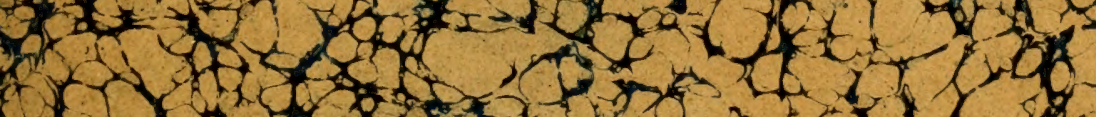

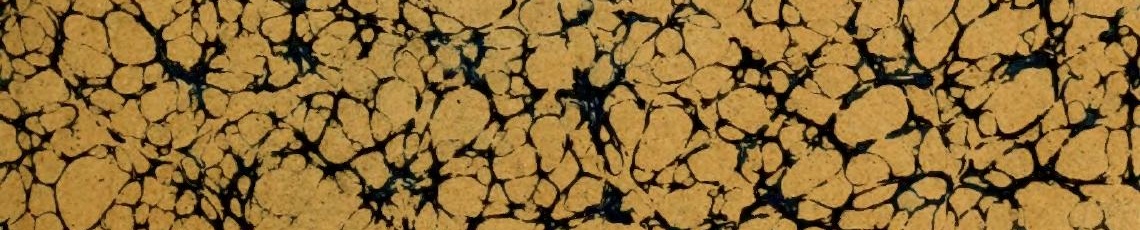
$1,1<+2$

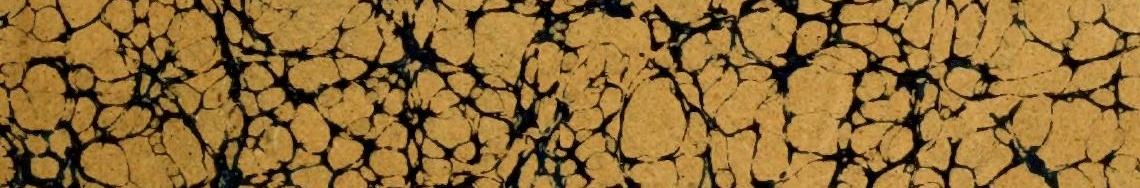
36. xpol 1041 - 1.to 13 1. 1 In 2 a

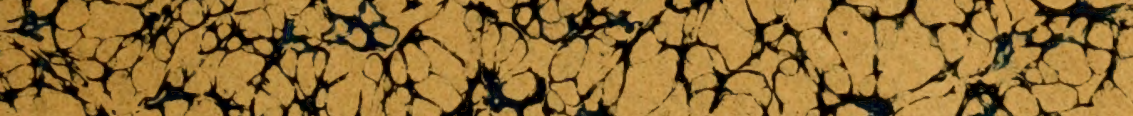
A t to i 101

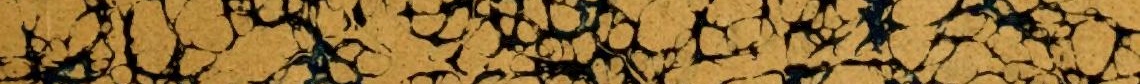
$340+75$

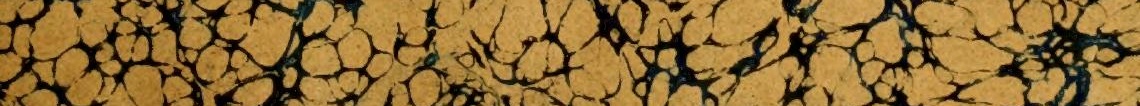



I MAWE

Dathion of Mollugliges Shesctionot Lithmory 




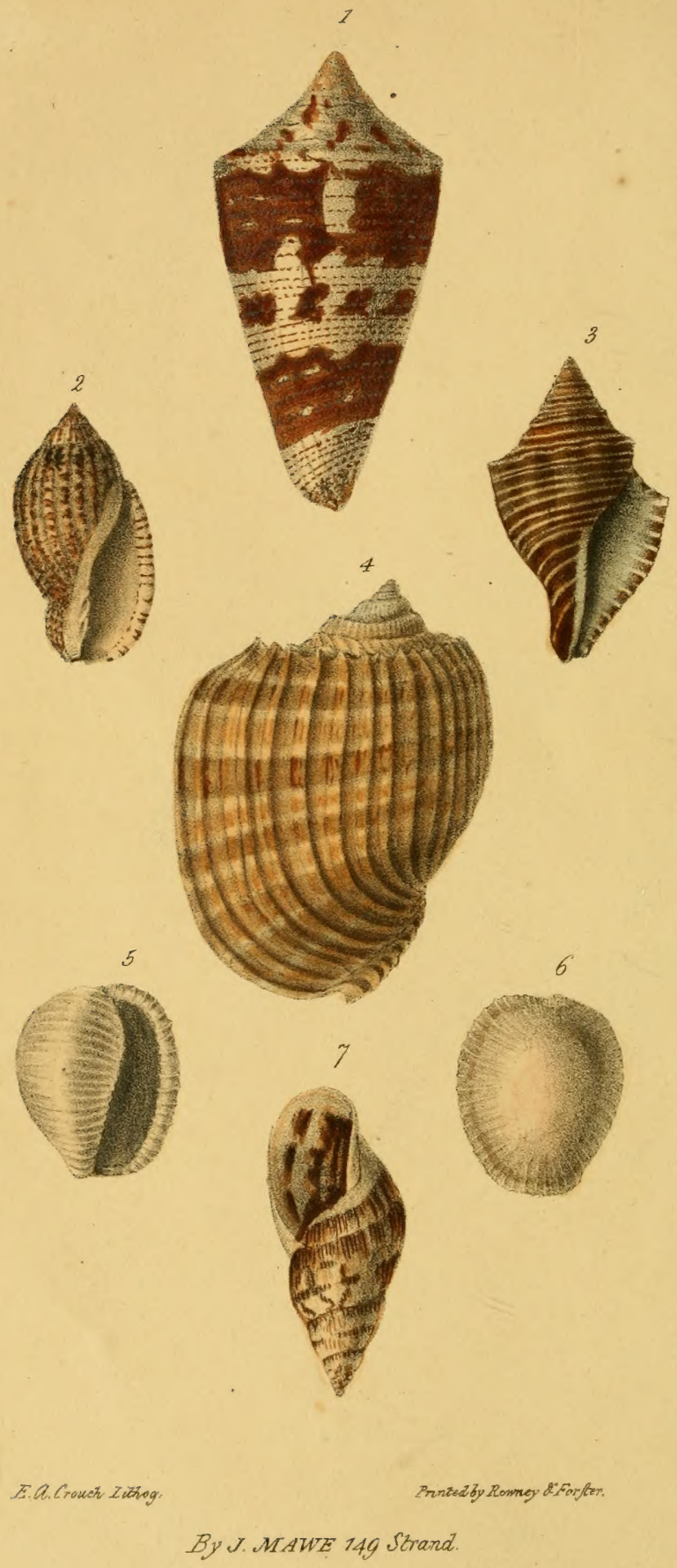




\title{
LINNAAN
}

\section{SYSTEM OF CONCHOLOGY,}

DESCRIBING

\section{The Orders, Genera, and Speries}

of

\section{SHELLS,}

ARRANGED INTO DIVISIONS AND FAMILIES:

\author{
WITH A VIEW TO FACILITATE
}

THE STUDENT'S ATTAINMENT OF THE SCIENCE.

\author{
BY \\ JOHN MAWE
}

Author of Travels in Brazil ; Treatise on Diamonds and Precious Stones;

Familiar Lessons on Mineralogy and Geology ;

\&c. \&c. \&c.

\section{Lonoun:}

PRINTED FOR AND SOLD BY THE AUTHOR, 149, STRAND; AND LONGMAN, HURST, REES, ORME, AND BROWN,

PATERNOSTER-ROW.

1823. 
\$ Mollusks

W. MiDonall Printer, Pemberton Ron Gough Square. 


\title{
THE PRESIDENT,
}

VICE-PRESIDENTS, AND FELLOWS

oF

\section{THE LINNEAN SOCIETY,}

\author{
Tyis วrtork
}

is RESPECTFUlLy DEDiCATED. 



\section{DESCRIPTION OF THE FRONTISPIECE.}

Fig. 1. Conus Cedo Nulli............ Vide Page 87

Fig. 2. * Voluta Harpa .................. 110

Fig. 3. Murex Argus ....................... 195

Fig. 4. Buccinum Costatum ................. 119

Fig. 5, 6. Cyprea Aperta $\ldots \ldots \ldots \ldots \ldots \ldots \ldots \ldots . \ldots 5$

Fig. 7. * Helix Papyracea ................ 168

* These Shells are sipposed not to be figured iu any former work on Conchology. 



\section{CONTENTS.}

Description of the Frontispiece $\ldots . . . \ldots \ldots$ Page v

InTRODUCTION '......................... ix

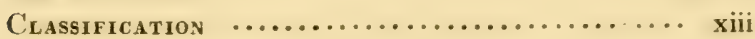

I. Multivalves $\ldots \ldots \ldots \ldots \ldots \ldots \ldots \ldots \ldots \ldots \ldots \ldots$ xiii

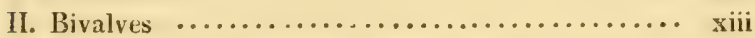

III. Univalves. -1 . With a regular spire $\ldots . . . \ldots$ xiv

2. Without a regular spire $\ldots \ldots \ldots . \mathrm{xv}$

I. MULTIVALVES.

Chiton ............................... 1

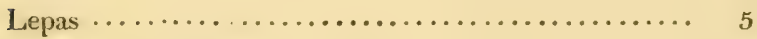

Pholas $. . . \ldots \ldots \ldots \ldots \ldots \ldots \ldots \ldots \ldots \ldots \ldots, 11$

II. BIVALVES.

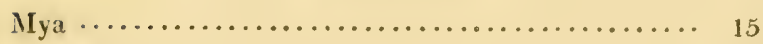

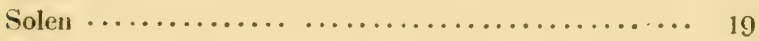

Tellina ............................ 23

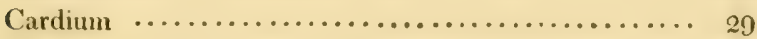

Mactra........................... $s s$ 
Donax............................ Page 37

Venus $. . \ldots \ldots \ldots \ldots \ldots \ldots \ldots \ldots \ldots \ldots \ldots \ldots \ldots, 41$

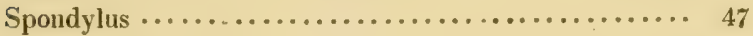

Chama ............................ 49

Arca ................................... 58

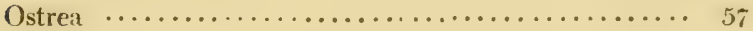

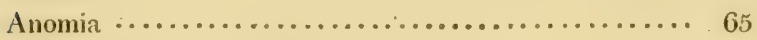

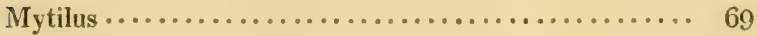

Pimna .................................. 75

1II. UNIVALVES.

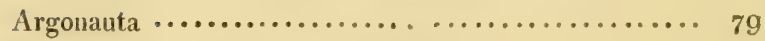

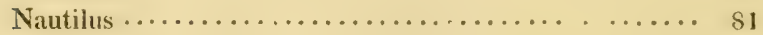

Conus ............................... 85

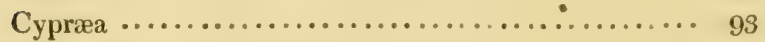

Bulla ............................... 99

Voluta ............................ 103

Buccinum .......................... 113

Strombus $\ldots \ldots \ldots \ldots \ldots \ldots \ldots \ldots \ldots \ldots \ldots \ldots \ldots \ldots . \ldots \ldots$

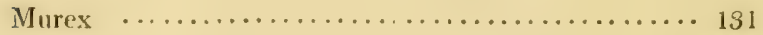

Trochus ... ........................ 141

Turbo $. . . \ldots \ldots \ldots \ldots \ldots \ldots \ldots \ldots \ldots \ldots \ldots \ldots . . \ldots \ldots$

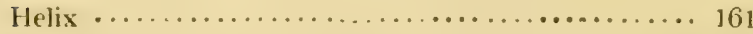

Nerita ............................ 179

Haliotis ......................... 179

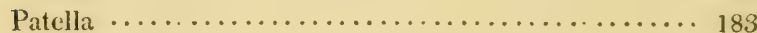

Dentalium .......................... 191

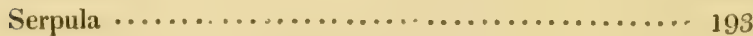

Teredo .............................. 197

Sabella............................. 199

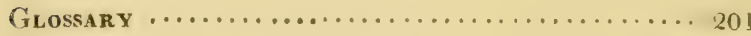




\section{INTRODUCTION.}

CONCHOLOGY is a science which embraces the knowledge, arrangement, and description of testaceous bodies, and which, according to the system of Linnxus, adopted in this Treatise, has for its basis the external form and character of the shell, and is totally independent of the animal enclosed within the calcareous covering.

The animal is a soft, fleshy, exsanguinous substance, without bones, but generally furnished exteriorly with a muscle, by which it adheres to the shell, occasioning certain indentations, thence called muscular impressions. Like other animals, it is endued with lungs, heart, mouth, aud organs peculiarly adapted to its nature.

The inhabitants of Multivalves and Bivalves are viviparous, but of Univalves some are oviparous. It appears from the investigations of Leuwenhoeck on Bivalves, and of Reaumur on Univalves, that the animal is furnished with a shell before it leaves the parent or the egg; and as it subsequently increases in magnitude, the part which is protruded beyond the original limits of the shell becomes covered with a viscous matter, which on desiccation forms a thin and clastie substance, in addition to the previous formation, 
and in time, by a repetition of the process, becomes of the same thickness with the other part of the shell. From the construction of Univalves it is evident, that this juxtaposition of successive layers can only take place at the aperture, and that in Bivalves the enlargement must proceed from the hinge round the circumference of each valve.

The submarine existence of the larger portion of these animals precludes, in a great degree, the knowledge of their nature and habits, and is one of the causes that Conchology still remains obscured and confused by anomalies in many of its genera, while other branches of natural history, from being more easily investigated, are better understood.

The character which appears to have guided Linnzus in the formation of his genera, was, in Multivalves, the position of the valves; in Bivalves, the peculiarity of the hinge; and in Univalves, the exterior figure of the shell, the columella, the aperture, and form of the mouth. Hence every bivalve exhibiting an ovate hollow in the hinge is termed an Ostrea; and in the Univalves a plaited columella constitutes the distinction of the genus Voluta, and an ovate aperture, terminating in a canal inclining to the right, distinguishes the genus Buccinmm. But to this arrangement it is objected, that the inhabitants of shells of the same genus ought to be identical: and on this supposition, as it appears impossible for the Ostrea malleus and Ostrea maxima to be the habitations of the same animal, they ought to be classed in different genera. Similar inconsistencies will appear from a comparison 
of the Voluta papalis with the Voluta turbinella, and of the Buccinum maculatum with the Buccinum patulum. How far these objections may be tenable it is not our purpose to enquire, being ourselves persuaded that the Linnæan system, though capable of considerable improvement, presents the most simple and concise method of aiding the investigation of this branch of natural history.

The striking dissimilarity of the species in some of the genera is certainly an olstacle to the attainment of the science; we have, therefore, with a view to facilitate its acquirement, and at the same time not materially to ciepart from the system we have adopted, formed divisions of the genera, when any marked dissimilarity was observable in the species. And if any of the divisions retained one leading character throughout, together with some other characters only partially, we have again divided it into families, distinguished by those variactions. It is possible that the characters of many of the divisions will be deemed sufficiently distinct to allow of their being formed into additional genera, without departing from the original system.

We have been indebted to other writers on Conchology for the addition of many new species, and particularly to Mr. Dil!wyn's valuable Catalogue of Recent Shalls.

Those species which were not found described or figured in the works of any anthor to which we had access, are distinguished by an asterisk; we have also named then, considering them to be new species; and have endeavoured in the catalogue, to place each 
next in succession to that species it most nearly resembles and approximates.

The first column of the Catalogue which follows the description of the genus will, it is presumed, be found to contain a comprehensive list of all the species at present described. In the second column is placed a list of the localities, which from our connections we have been able greatly to enrich and correct. The last column contains the trivial or common names.

The plates which embellish this work are taken from specimens in our own cabinet, and we are indebted to the kindness and indefatigable exertions of an artist of the greatest talent, for the accurate and elegant delineation of them. 


\section{CLASSIFICATION.}

LINN EUS has made three principal or grand divisions of Testacea, viz. Multivalves, Bivalves, and Univalves; of which he has given the following generic description.

\section{MULTIVALVES.}

1. Ciriton: Valves placed in transverse plaits down the back.

D. Lepas: Valves unequal; body sessile.

3. Pholas: Shell bivalve, with accessory valves at the hinge.

\section{I1. BIVALVES.}

4. Mra: Hinge with generally a broad thick tooth, not let into the opposite valve.

5. Solen: Shell open at each end; hinge with a single or double subulate reflected tooth, not let into the opposite valve.

3. 6. Telurna: Hinge with the lateral teeth of one valve not let into the other.

7. Cardium: Hinge with remote penetrating lateral teeth.

8. Macrna: Hinge with a complicated triangular middle tooth, and an adjoining hollow. 
6. Donax : Hinge with a lateral tooth, generally remote, not let into the opposite valve.

10. VENUS: Hinge with generally three approximate divaricated teeth.

11. SPondyus: Hinge with two teeth, separated by a small hollow.

12. Сиама: Hinge on one side, with an oblique obtuse tooth inserted into a corresponding cavity.

13. Arca: Hinge with numerous penetrating teeth.

14. Ostrea: Hinge without teeth, but an ovate hollow.

15. Anома: Hinge without teeth, but generally a linear depression on the rim, the beak of one valve curved over the hinge.

18. 16. Mytilus: Hinge without teeth, with a subulate depression.

17. Pinna: Hinge without teeth, valves united at one end, and open at the other.

\section{UNIVALVES.}

1. With a regular Spive.

1. 18. Argonauta: Shell with one cell, spiral, involute.

2) 19. Naurrus: Shell with many chambers, communicating by a tube.

20. Conus: Aperture effuse, longitudinal, without teeth.

21. Cyprea: Aperture effuse, linear, longitudinal, toothed on each side.

22. Bulla : Aperture rather contracted, and placed obliquely.

23. Voluta: Aperture effuse, the pillar plaited.

24. Buccinum: Aperture with a small canal leaning to the right.

25. Strombus: Aperture with a smill canal leaning to the left.

26. Murex : Aperture with a small straight canal. 
27. TRocrus : Aperture contracted, nearly rectangular.

28. Turвo: Aperture contracted, and orbicular.

29. Heurx: Aperiure contracted, lunate on the inner side.

30. Nerita: Aperture contracted, and semiorbicular.

31. Haliotis: Shell with a row of orifices along the surface.

2. Without a regular Spire.

32. Patella: Shell conic, the aperture widened like a basin.

39. Dentalium: Shell slender, subulate, open at both ends.

34. Serpula: Shell tubular, generally serpentine, adhering to other bodies.

35. Tereno: Shell thin, penetrating wood.

36. Sarella: Shell composed of agglutinated grains of sand. 



\section{INTRODUC'TION}

\section{To \\ $\mathrm{CON} \mathrm{CHOLOGY.}$}

\section{ORDER I.}

\section{feultibalues.}

CHiton._Coat of Mail.

DESCRIPTION OF PLATE I.

Dr. I. -Fig. 1. C. Squamosus. (Interior and exterior view.)

Brv. II. -Fig. 2. C. Marginatus. ditto.

Fig. 4. C. Fascicularis. ditto.

DFv. III.-Fig. 3. C. Spinosus.

Shell consisting of several valves, arranged longitudinally on the back of the animal.

THE genus Chiton ranks first in the classification of shells, and no less than forty species are known; some of which are beautifully marked, and some of rare occurrence. From the peculiar appearance of this multivalve, it is impossible to confound it with any other genus; and it may be observed, that all the species closely approximate each other. 
The Chiton, in its natural state, resembles a well known insect often met with in decayed timber, commonly called the wood-louse. Like the limpet, it is usually found adhering to rocks, and requires considerable force to detach it; it is occasionally seen rolled up in the form of a ball, among sea-weed and stones. It is common on our own coast, and is met with in France, Spain, and the Mediterranean, where it seldom exceeds an inch, but is generally much smaller, and in tropical clinates it sometimes occurs three or four inches long.

When the animal is extracted, the form of the Chiton is not unlike a boat. The termination of the valves which are seldom more or less than eight, is surrounded by a scaly or rough ligament, which enables the animal to expand and contract its shell freely.

The general appearance of the exterior of the Chiton is dull. Its color is dark brown, but it passes into different shades of green; some are variegated with beautiful pink, yellowish or bluish white; others exhibit various markings, in lively colors. The interior admits of considerable variation with regard to color, but the most prevalent is bluish black or white, diversified with yellow; also brown, green, and pink. The color of the margin is sometimes yellowish brown, or olive-green, with a reddish tint, but more commonly brown, approaching black.

The margins of some of the species have very different characters, which form distinctions for three divi-

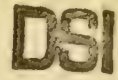


sions, viz. those having a scaly margin, as the C.squamosus, \&c. constitute the first division; others having a coriaceous margin form the second division; and the third consists at present only of one species, the C. spinosus, the margin of which is beset with spines.

The Chiton derives its name from its resem. blance to a coat of mail ( $X i \tau \omega \dot{y})$.

Specces I.-Having a scaly margin.
Scientific Name.
Locality.
Common Name.

Squanosus..... American Isles ........ Scaly Chiton ..

Bistriatus ...................... Striated ... do ..

Fasciatus ...... South America....... Banded ... do ..

Viridis ....................... Green $\ldots$... do ..

Tessellatus ..... St. Thomas's ......... Tessellated do ..

Sulcatus ....... South Sea Isles........ Furrowed.. do ..

Maculatus ..... East Indies .......... Spotted ... do...

Marmoratus.... Florida ............. Marbled .. do ..

Indus......... West Indies ........ Indıan ... do ..

Division II.-Having a coriaceons margin.

The C. porosus and C. larraformis of this division deserve particular notice, as in some respects their characters differ from those of the other species. The valves of the $C$. porosus are perforated by a small slit, and the ligament of the $C$. larvæformis (which in other species merely surrounds the margin) almost envelops the whole shell, and gives it the appearance of a caterpillar. 
Scientific Name.

Fulvus

Tunicatus.......

Castaneus.......

Lineatus ........

Aculeatus ......

Fascicularis .....

Punctatus.......

Ruber..........

Albus ..........

Cinereus .....

Bicolor ........

Ceracinus .......

Magellanicus....

Fuscus .........

Granulatus .....

Piceus ..........

Minimus.......

Cimex ..........

Asellus .........

Gigas ..........

Islandicus .......

Marginatus .....

Lavis

Amiculatus ....

Tuberculatus....

Crinitus

Thalassinus

Hispidus

Porosus .........

Larvæformis ....
Locality.

South America

.................. Coated ... do ..

Cape of Good Hope .... Chesnut ... do ..

Ditto .............. Striped ... do ..

Nicobar Isles .......... Prickly ... do ..

England \& Barbary .... Tufted .... do ..

Europe, Asia, \& America. Punctured. do ..

Norway ............ Red ..... do ..

England ............ White ... do ..

Goree ............. Grey ..... do ..

India .............. Variegated. do ..

Surinam ............ Cherry ... do ..

Magellan Straits ...... Magellan .. do ..

Pulo Penang ......... Brown ... do ..

West Indies .......... Granulated do .. Idria and Red Sea ..... Pitchy ... do ..

Norway ............ Mealy .... do ..

................... Bug-like .. do ..

................... Millepede - do ..

African Coast ......... Great .... do ..

Iceland ............ Iceland ... do ..

French Coast ......... Bordered .. do ..

England ............ Smooth .. do ..

Kurile Islands ......... Kidney shaped do

West Indies.......... Knobbed .. do ..

Aberdeen ............ Hairy .... do ..

................... Seagreen .. do ..

West Indies .......... Hispid ... do ..

Porous ... do ..

Caterpillar do..

\section{Division IlI.-Having a spınous margin.}

The C. spinosus is at present a very rare shell; its habitat is supposed to be the Marquesas.

Spinosus......... 
LePaS._Acorn Shell or Barnacle.

DESCRIPTION OF PLATE 11.

Dr. I. -Fam. 1. Fig. 1. L. Tintinnabulum.-4. L. Clavata.-5. L. Verruca. Fam. 2. Fig. 3. L. Quinquevalvis.

Fam. 3. Fig. 2. L. Purpurascens.

Bm II.-Fam. 1. Fig.6. L. Mitella.-8. L. Pollicipes.

Fam.2. Fig. 7. L. Anatifera.

Shell affixcd at the base, and consisting of many unequal erect valves.

OF the genus Lepas forty-three species are known, and they are in general so well characterized that they cannot be confounded with those of any other genus.

The exterior of the shell is often varied in shape, covering, and coloring; the usual outline is conical, but in some instances, hemispherical; which form is acquired by a number of valves being placed perpendicularly on a base, broad at the lower margin, and gradually tapering towards the summit, which is closed by other smaller valves, placed nearly horizontally, thereby serving as a lid or covering to the animal within. The perpendicular valves are incapable of motion; the horizontal, on the contrary, are moveable at the will of the animal; which through their medium, performs those functions that are necessary to its existence.

The number of valves which constitute the shell is often very indefinite, their usual amount is six; but the L. palmipes has sometimes only four; and 
other species possess the intermediate gradations of number, as far as twenty-four, which is not unfrequent in the $\mathbf{L}$. pollicipes.-The valves, of whatever number they consist, are variously diversified with strix, ridges, and grooves. The strix are mostly transverse; the ridges, on the contrary, are longitudinal, and not uncommonly beset with rough projections and acute spines, as in the L. spinosa.

The valves which compose the operculum, or lid, often vary in their number and shape; in some they only consist of two; in others, of three or four; and sometimes of a far greater number. They are usually attached to a ligament, and occasionally present an acute form, while in other species they are perfectly obtuse.

The color also differs considerably, though the most usual is of a bluish, purplish, or reddish cast; some are variegated with black and green, and others are greyish-white, as the L. mitella, \&c.

The Lepades are never found detached, but always fixed by the base or stalk to other bodies; they adhere in clusters to rocks, and often form groups on shells, loose stones, anchors, \&c.; they are also found on unarine animals, as the whale and the turtle. They also affix themselves to ships, and, though at first invisible, so rapid is their increase in magnitude and number, that the velocity of a vessel is considerably impeded by them. This seems to imply that the animal exists in the sea in the state of animalcula.

The interior of some species of this genus is a hollow tube, but in others it is divided into separate compart- 
ments or chambers, as in the L. diadema, or it is filled up with tubular pores, as in the L. porosa.

The species possessing these characters form the first, second, and third families of the first division; the fourth family is distinguished by having a cuplike appendage at the base; and the fifth by the shell being tubular and truncated at both ends.

The Lepas derives its name from its custom of adhering to rocks $(\lambda \varepsilon$ śç), and other projections in the sea.

This genus has also been called Balanus, from the resemblance which some of the species bear to an acorn ( $\beta a ́ \lambda$ avos).

Division I.-Affixed at the brse to other substances.

Fand 1 - Sessite.

Scientific Name.

Locality.

Common Name.

Balanus ...... Europe, \&c. ........ Acorn shell, com mon Barnacle..

Balanoides

Europe Smooth ... do ..

Tintimuabulum .. East and West Indies ... Bell-shaped do ..

Scotica ....... Scotland ........... Scottish ... do ..

Costata ...... Wales............. Ribbed ... do..

Conoides ...... Weymouth ......... Conic .... do ..

Palmipes....... Atlantic lsles ........ Palmated.. do ..

Minor ........ Indian Isles ......... Flesh colored do..

Angustata...... Coast of Africa, \&c. .... Narrow mouthed.

Elongata ...... Britain, \&c. ......... Club-like - do ..

Patellaris ..... Coast of Coromandel, \&c. Limpet-like do ..

Spinosa ....... St. Helena .......... Spinous .. do ..

Violacea ...... Indian Isles ......... Violet .... do ..

Crispata ...................... Rugged . . do ..

Verruca....... North Furope......... Wart formed do..

liugosa ...... Sonth Coast of England. Wriukled : do .. 
Scientific Name.

Punctatus

Radiata.........

Cariosa ........

Psittacus . ......

Hemispherica ...

Lavis .........

Striatus $\ldots . .$. .
Locality.

British Seas........... Punctured B. .

.................. Rayed .... do ..

$\ldots \ldots \ldots \ldots \ldots$ Ridged .... do ..

Chili .............. Beaked ... do ..

Africa.............. Hemispherical do

East and West Indies ... Smooth.... do ..

English and Dutch coasts Striated .. do ..

FAMILY 2.-Having radiated cells at their base.

Diadema ...... Mediterranean, \&c.... Turban Barnacle Balanaris ...... ................. Whale . .. do .. Testudinaria .... ................ Turtle .... do ..

- Quinquevalvis.. ................. Five valve do ..

FamiLY 3.-Huving a porous base.

Porosus ...... East Indies, \&c....... Porous Barnacle Purpurascens... Falkland's Isle ....... Purple... do ..

FamiLy 4.-Having a cup-like appendage at the base.

Galeata ....... Mediterranean, \&c..... Helmet-like do .. Spongeosa ..... Dorsetshire ......... Spongy ... do ..

Famicy 5.-Tubular and truncated at both ends.

Tracheaformis

Windpipe - do ..

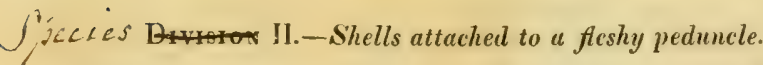

Notwitlstanding the great affinity which exists throughout the Lepas genus, there are a few exceptions, in which a resemblance is difficult to be traced; as, for example, in the $\mathbf{L}$. scalpellum, $\mathbf{L}$. anserifera, $L$. anatifera, and varieties emanating from them. These three species are closely allied to each other, but exceedingly dissimilar to the rest of the genus, for the generality of Lepades are affixed to 
other bodies or substances by the base, or lower part of the shell; but these are attached by a peduncle or stem, which proceeds from the base of the shell to the substance which sustains it.

The stems differ exceedingly in character and substance; they sometimes resemble a smooth, filmlike tube, of a fine texture, not unfrequently tinged with bright red or orange; they are also often of a dark or bluish-brown color, the texture much coarser, and wrinkled, or granulated with little warts.

The peculiar structure of these species has caused them to be compared to the crocus, to which in appearance they bear a considerable resemblance.

The above species characterize the second division, which is subdivided into three families, distinguished by the number and position of the valves. The first consists of those species which have five valves, and a wreath of smaller ones round the base, as in the L. pollicipes. In the second family the valves are contiguous, as in the L. auserifera and L. anatifera, which are almost invariably composed of five valves; they are also supplied with beautiful feathery tentacula of a brown colur, and elegantly curled. In the third family the valves are minute and not contiguous.

FAury 1.-Having move than five valves, and a wreath of smaller ones round the base.

Scientific Name:

Locality

Mitella...... Amboyna \& East Indies.. Mitred Bamacle

Scalpellum..... Spain, \&c.......... Knife-like.. do..

Pollicipes ..... France and Spain ..... Corucopia do.. 
FamuY ¿.-Having only five contiguous valves.

Scientific Name.

Locality.

Common Name.

Anserifera ..... American and Indian seas Striated Barnacle

Anatifera ...... Ditto .............. Duck .... do ..

Dorsalis ....... West Indies .......... Wrinkled .. do ..

Fascicularis .... European seas ......... Bladder-like do ..

Vellosa ........ Mediterranean ....... Downy .... do..

Dentata ....................... Toothed $\ldots$ do ..

Sulcata....... Dorsetshire ......... Furrowed . do ..

FaniLy 3.-Having minute and distant valves, placed on the fleshy extension of the peduncle.

Aurita ....... Northern Coast ....... Eared Barnacle Vittata ....... Mediterranean \& Atlantic Ribband .. do .. 


\section{Pholas. - Stone-piercer.}

\section{DESCRIPTION OF PLATE III.}

Fig. 1. P. Striata. (In the wood.)

Fig. 2. P. Candida.

Fig. 3. P. Dactylus.
Fig. 4. P. Costata.

Fig. 5. P. Papyracea.

Shell having two primary valves, divaricate, with several smaller, differently-shaped accessory valves at the hinge:-hinge recurved, united by a cartilage; in the inside, beneath the hinge, is an incurved tooth.

IT appenrs that only twelve species of this genus have been enumerated, and some of these are so alike, that in many instances, they might be considered as mere varieties rather than different species; however, they all possess sufficient determinate characters to prevent their being blended with bivalves.

The form of the Pholas is in most species ovate or oblong, constituted by two large valves opposite to each other, and to which is attached, on the back of the shell, a number of smaller ones, that act as substitutes for a hinge, which in bivalves generally determines the generic character.

Another character of the Pholas is, that the valves (the two large ones) never shut close, they invariably are open at onc end, and, in most instances, at both.

In the interior of the shell, in each valve, nearly in the middle, is an incurved tooth, sometimes of considerable length, and which has been considered peculiar to the genus.

The exterior of the Pholas is generally destitute of color; sometimes it partakes of a brownish cast, but 
the shell is usually of a pure or dusky-white: however, the absence of color is amply compensated by the beautiful fret-work with which the shells of this genus are adorned.

In some species the reticulations are so delicate in their structure, as to resemble the finest lace; in others the texture is coarser, and approaches nearer to small basket-work; and in the P. costata the shell is covered with regular, elevated, jagged, or scalloped ribs, elegantly disposed.

The Pholades are found occupying separate and distinct habitations, which they form in limestone, indurated clay, wood, coral, \&c.; even the thick oak planks of ships are pierced by them: and as they advance in growth, they enlarge their habitation within, leaving the small aperture, by which they originally entered, of its primitive size.

The animal possesses the property of emitting a phosphorescent liquor, which shines with brilliancy, and illuminates whatever it touches.

The American, Indian, and European seas supply all the species that are known.

It is common in limestone, sandstone, \&c. on the coast of England.

The Pholas derives its name from $\phi \omega \lambda \varepsilon \omega$, alluding to its custom of forming cells in rocks, \& $c$.

Scientific Name.

Dactylus .......

Costata........
Locality.

Europe ..............

Virginia, West Indies, South Europe, South

Carolina..........

Striata ........ South Europe, E. I. Ocean

Candida....... Europe, America, Britaiu, Bay of Campeachy ....
Common Name.

Prickly Piercer..

Ribbed.. do ...

Striated.. do ...

White... do... 
MULTIVALVES._PHOLAS.

Scientific Name.

Crispata....... North Europe, Britain .. Curled Piercer..

Orientalis....... Siam and Tranquebar... Indian ... do ...

Cordata ........................ Heartshaped do..

Chiloensis ..... Chili .............. Chili .... do ...

Hians ........ West Indies ......... Gaping ... do ...

Parva ........ Pensacola, Britain ..... Small .... do ...

Falcata........................ Hooked .. do ...

Papyracea .... Britain ............ Paper.... do... 



\title{
ORDER II.
}

\author{
Bibalues.
}

MYA. -Trough-shell, or Gaper.

DESCRIPTION OF PLATE IV.

Fig, 1. M. Arenaria.

Fig. 2. M. Pubescens.
Fig. 3. M. Corrugata.

Fig. 4. M. Aurita.

Shell bivalve, generally gaping at one end.

THIS genus is placed by Linnæus the first on the list of Bivalves; the number of its species amounts to forty.

The principal characteristic of the Mya consists in its gaping at one end: the next general distinguishing mark is, its having a single, broad, patulous tooth, proceeding from beneath the beak. It is much wider and broader at one end than the other; and the broadest end has an excavation, which gives it the appearance of the bowl of a spoon.

The form of the Mya varies exceedingly: some are oblong and truncated; others, again, are orbicular or round; and many are angular or eared. 
The greatest part of them are covered with a thick brown or green epidermis; when this is removed, and the shell polished, brilliant prismatic hues are displayed.

In some places the Mya constitutes a considerable portion of food for man, birds, \&c. They have a pro. pensity to burrow in the sand and inud, in which they are wholly or partially concealed.

The Mya is derived from $\mu \dot{v} \boldsymbol{\xi}$, which was applied by the antient naturalists to the genus Mytilus.

Drvisros I.-Hinge with one or two rounded teeth, not inserted in the opposite valve.

Some species of this division grow to a large size, as the M. glycymeris.

Scientific Name.

Glycymeris ..... Mediterranean Sea, Spain, Portugal, and Naples..

Truncata....... Europe, Britain ........

Arenaria........

Declivis.........

Pubesceus.......

Prætensus.......

Anatina.........

Globosa........

Nicobarica......

Rostrata.......

Distorta .......

Bidentata ........

Decussata

Purpurea

Ferruginosa.....

Nitens ..........

Prismatica ......

Substriata ......
Ditto................. Sand .... do ..

Devonshire, Weymouth.. Sloping ... do ..

Ditto ............... Pubescent.. do ..

Britain .............. Spoon-hinge do ..

Mouth of the Niger ..... Duck ..... do ..

................... Globular .. do ..

Nicobar Islands ........ Nicobar ... do ..

Bergen .............. Beaked .... do ..

Plymouth............ Deformed.. do ..

Deronshire........... Double-toothed do

Frith of Forth ......... Decussated do ..

Devonshire........... Purple .... do ..

Belton Sands, Dunbar... Rusty ..... do ..

................... Glossy .... do ..

Scotland, Devonshire.... Prismatic .. do ..

Devonshire ........... Substriated do .. 
Divisios Il.-Hinge callous, without teeth.

Scientific Name.

Edentula

Membranacea...

Norwegica......

Siliqua........
Locality.

Caspian Sea........... Toothless Gaper

Iceland............. Membraneons G.

Norway .............. Norwegian do..

N. America .......... Bean-pod... do

Division III.-Hinge with teeth inserted into the opposite ralie.

The M. ponderosa, or M. crassa of some authors, with others in this division, are remarkable for their excessire weight and thickness; which is unirersally the case with those that are found in rapid rirers and cataracts.

The I, margaritifera is famous for the production of fine pearls, and was formerly found in great quantities in the rirer. Conway in Wales, and in Scotland.

Scientific Name.

Batara ....... Damube, Rivers of Holland

R. Kenmet...........

Pictorum....... European Rirers........ Painters... do ..

Orata ........ Rirers of England ..... Oval ..... do ..

Radiata....... Rivers of Malabar...... Radiated .. do ..

Ponderosa ..... Chivese Rivers ........ Ponderous - do ..

Complanata .... North American Rivers.. Smooth.... do ..

Nodulosa ...... Rivers of North Europe.. Knotted ... do ..

Margaritifera.... Rivers of Coromandel... Pearl ..... do ..

Corrugata...... Ditto .............. Wrinkled.. do ..

Rugosa ........ Ditto............. Rough .... do ..

Variabilis ...... South American Rivers.. Variable .. do . 
Scientific Name.

Nodosa ........

Syrmatophora...

Suborbicularis..

Inæquivalvis

Labiata

Aurita.
Locality.

Rivers of India...

Rivers of Guinea ........ Angular .. do ..

Coasts of Devonshire.... Roundish .. do ..

Coasts of Britain....... Inequivalve do ..

South American Rivers .. Lipped ... do ..

Ganges.............. Eared .... do..

Division IV.-Hinge toothless, with a conical rounded hollow for the reception of the cartilage.

Vulsella ....... Amboyna, Tranquebar .. Tweezer .. do .. 


\section{SOLEN.-RAZOR-SHEATH OR KNIFE-HANDLE.}

\section{DESCRIPTION OF PLATE V.}

Drw. I. -Fig. 2. S. truncatus. Drv. II.-Fig. 4. S. vespertinus.

Fig. 3. S. vagina. Fig. 5. S. radiatus.

Drv. II._Fig. 1. S. oriens. Fig. 6. S, occidens.

Shell bivalve, oblong, open at both ends: hinge with a subulate reflected tooth, often double, and not inserted in the opposite valve.

OF this genus there are thirty-five species, which vary exceedingly in form and general appearance.

The principal characteristic is derived from the hinge, usually supplied with one subulate tooth, which is often found double, though not always inserted in the opposite valve.

Most species of the Solen are covered with a thin cuticle or epidermis, which renders the colors beneath more or less obscure.

The first division consists of those species, whose breadth greatly exceeds their length; and the second, of those that are oval or oblong.

In some species of the first division, as in S. siliqua S.vagina, \&c. the breadth of the shell is nearly seven times its length, giving it a resemblance to the handle of a knife, or sheath of a razor; and some are curved or bent like the scabbard of a scimitar. The shells of this division have both ends invariably open.

The greater proportion of the shells of this genus are found in the European and Northern seas. The 
Indian, American, and Mediterranean seas also produce many species.

The Solen derives its name from $\sigma o \lambda \dot{\eta} v$, a tube.

Division I.-Shell linear.

Scientific Name.

Vagina

Truncatus

Novacula...... .

Siliqua........ .

Linearis .........

Ensis

Pellucidus

Legumen........

Cultellus
Locality.

Britain

American and Indian Seas

Wales

Europe

Indian Seas ...........

Europe...........

Britain

Mediterranean, Britain..

Ceylon ...............

\section{Common Name.}

Razor Sheath ..

Truncated R.S...

Knife .... do ..

Pod-like .. do ..

Slender... do ..

Sword ... do ..

Pellucid ... do ..

Pease-cod.. do ..

Kidney-shaped do

\section{Drvisron II. -Shell ovate or oblong.}

The shells of this division present but little beauty, with the exception of the S. oriens, S. radiatus, S. roseus, and a few others, which have a fine pink color, or are delicately rayed with purple and white. Some species of this division closely resemble the Tellinx, but they may always be distinguished by an examination of the hinge.

Scientific Name.

Antiquatus .....

Gigas ..........

Magnus .......

Minimus .........

Guineensis ......

Inflexus ........

Diphos .........

Radiatus ........
Locality.

Britain ................ Antique R. S. .

N. W. Coast of America. Giant ..... do ..

Indian Isles ......... Great .... do ..

Tranquebar........... Small .... do ..

Guinea ............. Guinea .... do ..

................... Inflected .. do ..

Indian Ocean ......... Violet .... do ..

China, Amboyna ...... Rayed .... do .. 
BIVALVES-SOLEN.

Scientific Name.

Strigilatus

Coarctatus......

Fragilis .......

Anatinus .......

Roseus .........

Striatus ........

Castrensis ......

Biradiatus ......

Sanguinolentus ..

Oriens .........

Occidens ........

Amethystus .....

Variegatus ......

Bullatus

Minutus ........

Virens ........

Squamosus......

Vespertinus.....
Locality.

Mediterranean

Nicobar Isles, Britain .. Narrow .... do .

Nicobar Isles, Britain ... Brittle ... do ..

Coromandel Coast ..... Duck's-bill do..

Red Sea ............ Rose-colored do..

Indian Seas .......... Striated ... do ..

Guinea Coast ......... Zigzag ... do ..

South Seas........... Double rayed do

West Indies ......... Sanguineous do..

China ............. Rising Sun. ....

Ceylon ............... Setting Sun ....

Indian Seas ........... Amethyst R.S. ..

.................. Variegated do...

East and West Indies... Inflated .. do ..

Great Britain, N. Europe Minute.... do ..

Coast of Java . ....... Green .... do ..

Devonshire ......... Scaly .... do ..

European \& Mediterra-

nean Seas........... Vesper.... do .. 



\section{TLLLINA.-TELLEN.}

\section{DESCRIPTION OF PLATE VI.}

Div. I.-Fig. 1. T. virgata.

Drv. I. -Fig. 4. T. Ferroensis

Drv.II.-Fig. 2. T. foliacea. Fig. 3. T. rostrata.

Fig. 5. T. tenuis.
Drr. II. -Fig. 9. T. inæquivalvis.

Drv III.-Fig. 6. T. Hlexuosa.

Fig. 7. T. crassa.

Fig. 8. T. cornea.

Shell bivalve, generally sloping on one side: in the fore part of one valve there is a convex, and in the other a concave fold; hinge with usually three teeth, the lateral smooth in one valve.

OF this genus there are eighty-one species. Of all the different genera of Bivalves, there are none, except the Venus, which can vie with the Tellina in beauty, variety, or number.

The usual form of the Tellinæ is broad at one eud, and gradually tapering towards the other; in some cases the pointed termination of the shell forms a bcak, as in the T. rostrata, T. rufescens, \&c. Others, on the contrary, are more orbicular, as the T. scobinata, \&c. and some, as the T. gari, \&c. are nearly allied to several species of the genus Solen, for which they are sometimes mistaken; however, from the more acute termination of the beak in the Tellinie, the difference may be easily distinguished. The hinge of the Tellina will also assist in removing any doubt that may have originated from an inaccurate examination of the shell; for it is usually furnished with three teeth, the middle one often cleft, and the lateral teeth 
most commonly smooth. The interior margin is rarely crenulated.

The exterior of these shells varies materially, some being perfectly smooth and polished, whilst others are covered with minute striæ and undulations; and occasionally the whole surface is beset with imbrications or scales.

Some species of the Tellina are remarkable for their beautiful radiations, the colors of which are rarely to be equalled in any of the other genera.

The Tellinæ are produced in abundance in almost every sea; the rivers, pools, ponds, and marshes of Europe and America supply only a few. The finest varieties are found in the pearl fisheries of Ceylon.

The Tellina takes its name from $\tau_{\varepsilon} \lambda \varepsilon i \omega$.

\section{Division I.-Ovate and thickish.}

Scientific Name.

Gargadia ....... Indian Ocean .........

Rugosa ........ Otaheite, W. Indian Seas

Lingua Felis ....

Marginalis

Virgata ........ Amboyna, Ceylon, Bay of Naples, Moluccas ....

Interrupta ...... West India Islands .....

Angulata ....... Tranquebar, Mediterra-

Inflata $\ldots . . .$. .

Polygona ....... Tranquebar, Naples ....

Lacunosa ....... Coast of Guinea ........

Gibbosa .........................

Gari ......... Amboyna, Molucca Isles,

China ............. Varying .. do ..

Ferröensis ..... Britain, Ferroe Isles, Nor-

way............ Carnation + do ..

\section{Common Name.}

Toothed Tellen

Rugged .. do ..

Cat's tongue do

Margined.. do ..

Striped .... do ..

Freckled .. do ..

Angular .. do .

Inflated .. do ..

Polygonal - do ..

Marshy ... do ..

Gibbous .. do .. 
Scientific Name.

Fragilis ....... European Ocean, Caspıan sea, Mediterranean...

Obliqua
Locality.

Common Name.

Brittle Tellen ..

Oblique .. do ..

Division II.-Ovate and compressed.

Triangularis ....

Oblonga ........

Spengleri .......

Foliacea

Acuta

a .........

Planata $\ldots . . .0$.

Strigosa

Lævigata ......

Madagascariensis

Radiata

Pallescens

Rostrata

Rufescens.......

Flavescens

Hyalina ........

Inæquivalvis .

Trifasciata

Incarnata

Opalina ........

Lanceolata .....

Sanguinea ......

Nivea .........

Sulcata .......
Triangular do..

European Ocean ....... Oblong .. do ..

Nicobar Isles, Coromandel, China ......... Amboyna, Molucca Isles, Golden .... do .. West Indies ......... Sharp edged do ..

European and Mediterranean Seas ......... West Coast of Africa, Molucca Isles ....... Fasciated .. do ..

European \& Indian oceans, West Indies ........ Smooth .. do ..

Coasts of Madagascar, Coromandel .........

European Ocean, Bahamas, Ascension Island, West Indies ........ Rayed .... do .. East Indian Seas ....... Amboyna, Java, Tranquebar ............... Coasts of Brazil ........

East Indian Seas ....... Coasts of Guinea ....... Mediterranean, Norway, Britain ............. European Ocean ....... Mediterranean ......... Mediterranean, Sweden. Nicobar Isles, Tarentum . East Indian Seas ....... .................... American Ocean ....... A....................
Flat ..... do ..

Madagascar do ..
Beaked .... do .. Red ...... do .. Yellow.... do .. Glassy ... do .. Inequivalve do .. Three banded do Scarlet ... do .. Flesh color'd do .. Opaline .. do .. Lance-shap'd do. Sanguineous do .. Snowy .... do .. Sulcated . do .. 
BIVALVES_TELLINA.

Scientific Name.

Donacina......

Angusta ........

Truncata .......

Punicea .......

Depressa .......
Fabula......

Tenuis

Vitrea

Striat:

Balaustina

Calcaria .........
Locality.

Mediterranean, Britain ..

Frith of Forth .........

Java ................

West Indian Seas, Coasts of Britain and Guinea, Rhode Island ........

Coasts of Britain ....... Mediterranean, Coasts of Norway and America, West Indies, Britain .. Coasts of Britain ........ Baltic, Northern Ocean .. Coasts of Dorsetshire ... Mediterranean ......... Coasts of lceland, Ferroc Isles ..............

\section{Division III.-Sub-orbicular.}

Remies

Reticulata.....

Cancellata ......

Guinaica .......

Scabra ........

Crassa ........

Decussata ......

Cordiformis .....

Muricata ......

Scobinata ......

Lactea.........

Rotundata e....

Flexиома........
European and Indian Oceans, Coasts of America, Nicobar Isles ...

West Indies, Dorsetshire

West India Isles, Britain

Coasts of Goree ........

Coasts of Guinea, Frith of Forth ...........

West Indiai Seas .......

Guernsey, Britain, Normandy ............

(...................

West Indian Seas .....

West Indian Seas, Coasts of Terra Firma ......

Asiatic Ocean, Coasts of Surat, Jamaica, \& Bar-

Mediterranean, Lisbon, Norway, Senegal, Britain Coasts of Britain ...... badoes ............. Britain ..............
Common Name.

Donax Tellen .. Narrow ... do .. Truncated. do ..

Flat striated do .. Depressed do ..

Semi-striated do.. Thin ...... do.. Transparent do.. Striated .. do.. Pomegranate do.. Chalky ... do ..
Waved.... do .

Obsolete .. do . .

Netted .... do ..

Reticulated do..

Guinea.... do ..

Rough ... do..

Thick .... do .

Decussated do..

Heart shaped do .

Prickly .... do ..

Rasp ... do..

Milky .... do..

Round .... do ..

Crooked .. do .. 
BIVALVES_TELLINA.

Scientific Name.

Locality.

Common Name.

Carnaria ...... West Indies, Curacoa, Britain ............ Pink Tellen .

Zonata....... Mediterranean, Britain,

West Indies ......... Banded .... do ..

Bimaculata .... European Ocean, East and West Indian Seas

Balthica ....... The Baltic ..........

Pisiformis ...... Mouths of Rivers in the

European Seas .......

Divaricata ... .. Coasts of Brazil, Mediterranean, American Seas, Naples ............ Obliquely striated

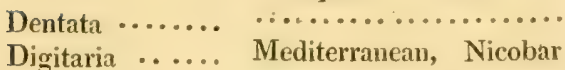
Isles ............ Digital .... do ..

Cornea ........ Rivers \& ponds in Europe

Lacustris ...... Denmark, Britain ....

Amnica ....... Denmark, Britain .....

Pusilla........ Rivers in Europe and Virginia ............

Limosa ........ Rivers in South America

Fluminalis ..... Euphrates ...........

Hermaphrodita .. Guinea ..............

Fluminea ..... Rivers of China .....

Double spot do .. Baltic .... do ..

Pea ..... do .. Toothed ... do .

Horn colored do.. Lake .... do .. River .... do .. Minute.... do .. Maton's ... do .. Euphrates...do.. Olive ..... do .. Ribbed.... do ..

Filuviatilis ..... Canton ........... Chinese... do .. 



\title{
CARDIUM_Cockle or HEarti-shell.
}

\author{
DESCRIPTION OF PLATE VII.
}

Drv. I. -Fam. 1. Fig. 3. C. cardissa.

Drr. II. - Fam. 1. Fig. 6. C. retusum.

Fam. 2. Fig. 8. C. isocardia.

Fam. 4. Fig. 1. C. medium...-Fig. 4. \& 5. C. parrum.

Drv. III.-Fam. 1. Fig. 7. C. lævigatum.

Fam. 2. Fig. 2. C. serratum.

Shell bivalve, nearly equilateral, equivalve, generally convex, longitudinally ribbed, or striated, with a crenaled margin: hinge with two teeth near the beak, and a larger remote lateral one on either side, each locking into the opposite valve.

THIS genus contains forty-seven species, which vary much in color and structure. The most general shape is convex or orbicular; some are elongated and compressed; and others have the form of a flattened heart.

The general characteristics of this genus are longitudinal ribs and grooves, proceeding from the umbones to the margin, and crossed by delicate strix, like the common Cockle, but more distinctly articulated. In some species the surface is smooth and polished; and in others, the ribs are beset with rows of acute spines. The interior margin is almost universally crenated.

The umbones of the shells of this genus differ considerably in position: in some they are placed opposite each other, remote or approximate; and in others alternating. This variety of appearance has caused 
the Cardia to be separated into three divisions, and those divisions into families.

Specimens of this shell are found in almost every sea, and some, though rarely, at the mouths of the rivers Tees, Thames, \&c.

This genus has been named Cardium from the re-

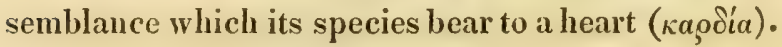

Division I. - Heart-shaped, valves compressed, umbones alternating.

Scientific Name.

Locality.

Common Name.

Cardissa ....... East Indies .......... Venus's Heart ..

Humanum .. ... East Indies .......... Concave.... do ..

Roseum ...... Malay coast......... Rose ...... do ..

Monstrosum .... South Sea Isles ........ Recurved... do ..

Division II.-Sub-cordate, longitudinally ribbed.

One of the most rare species of this division is the C. costatum, which has rows of white, hollow, elevated ribs, situated at regular distances, proceeding from the umbones to the margin; and the spaces between them are, in perfect specimens, of a fine dark brown color.

The C. fragum and $\mathbf{C}$. unedo differ from the other species of this division, their ribs being armed with small crescent-shaped scales.

Famrix 1.-Having a crescent shaped cavity beneath the umbones. Retusum ...... India ............. Diana's Heart... 
FAMLy 2.-Ribs armed with nodules, elevated rough strio, wrinkles or scales.

Scientific Name.

Edule.

\section{Unedo}

Fragum .........

Hemicardium....

Tuberculatum ...

Isocardia........

Pectiniforme ....

Regulare........

Glaucum .......

Fasciatum ......

Elongatum . ....

Leucostomun....

Magnum .......

Rigidum .......

Maculatum .....
Locality.

Britain

India ................

Ditto ..................

Ditto........ .4 Heartshaped C

Mediterranean ......... Tuberculated do .

East \& West Indies ..... Imbricated do ..

.................... Pecten .... do ..

West Indies .......... Regular ... do ..

Mediterranean ........ Chamelion do ..

Britain ............ Banded.... do ..

Ditto............... Lengthened do ..

West Indies........... White mouth'd C.

................. Great..... do ..

................. Rigid .... do ..

Ceylon ............ Spotted.... do ..

FAMLY S.-With ribs armed, more or less spined.

Flavum ....... Ceylon ............ Yellow.... do ..

Spinosum ...... Mediterranean ....... Spined .... do ..

Echinatum .... Ditto, Britain......... Thorny ... do ..

Lima......... East Indies .......... Asiatic ... do ..

Muricatum ..... West Indies .......... Prickly .... do ..

Rugatum ..... East \& West Indies .... Gaper.... do ..

Latum ........ East Indies ......... Broad .... do ..

Ciliatum ....... Greenland ......... Fringed ... do ..

Aculeatum ..... Britain ............. Spinous... do ..

Muricatulum .... Coast of Kent ........ Minute .. do ..

FamiLY 4.-With ribs unarmed.

Costatum

Africa.............. High ribbed do ..

Medium ....... West Indies, Britain .... Marbled .. do ..

Donaciforme .... West Indies ........... Triangular . do ..

Exiguum ...... Britain .......... Pigmy .... do .. 
Scientific Name.

Ringens .........

Oblongum .......

Papyraceum ....

Fimbriatum ....

Rusticum ......

Islandicum .....

* Parvium .....
Locality.

Africa

Mediterrumean ................. Furbelowed do.. Mediterranean ........ Banded.... do .. Greenland ............ Iceland .... do .. Coast of Hampshire .... Diminutive do ..

Division 111.-Sub-cordate, obsoletely ribbed, striated or smooth.

FamiLy 1.-Obsoletely ribbed.

Lævigatum ..... Britain, Mediterranean .. Smooth Cockle..

FAMILY 2.-Lightly striated, approaching smooth.

Lineatum ...... East Indies........... Streaked Cockle Serratum ...... W. Indies, Mediterranean Citron.... do.. Grœnlandicum .. Greenland seas ........ Greenland. do .. Æolicum ...... Africa ............. Janus .... do .. Rubrum ....... Britain ............ Red ..... do.. 
BIVALVES_MACTRA.

\title{
MACTRA.—KNEADING-TROUGH.
}

\section{DESCRIPTION OF PLATE VIII.}

\author{
Drv. I.-Fam. 1. Fig. 1. M. carinata. \\ Fam. 1. Fig. S. M. cinerea. \\ Fam. 1. Fig. 5. M. stultorum. \\ Fam. 2. Fig. 2. M. violacea. \\ Fam. 2. Fig. 4. M. subtruncata. \\ Drv.II.-Fam.2. Fig. 6. M. listeri. \\ Fam. 3. Fig. 7. M. lutraria.
}

Shell bivalve, inequilateral, equivalve: middle tooth of the hinge complicated, with a small hollow on each side; lateral ones remote, and inserted into each other.

THE genus Mactra possesses little beauty or variety. The number of species amounts to forty-two, and a similarity of coloring and form pervades the whole.

The shape of the Mactra is subtriangular, or oblong. The exterior is generally smooth, or delicately striated; but in some species it is transversely wrinkled or ribbed. The valves in a few specimens gape at both ends, in others at the anterior only, and some have both ends closed. These characters form the distinctions of the divisi ans and families of the genus.

The most prevailing color is lilac, or white tinged with blue or yellow, and some species have delicate rays of purple upon a brown ground. The Mactra have a semipellucid appearance, and are generally thin, brittle, and remarkably light.

The hinge of the Mactra, by which it is distinguished from all the other genera of Bivalves, is of a triangular 
form, and has a small hollow on each side; and though it is very strongly articulated in some species, the teeth are universally thin and fragile. The interior margin is rarely crenated or toothed.

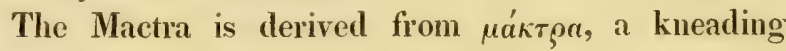
trough.

Divisron I.-Shell sub-angular:

Famror 1.-Having a smooth surface.

Scientific Name.

Spengleri .......

* Cariuata ....

Maculata.......

Corallina........

Lactea........

* Cinerea .......

Stultorum.....

Grandis .......

Achatina ......

Triangularis ....

Minutissima .....

Donaciformis ....
Locality.

Cape of Good Hope .... Spengler's Mactrie Mediterranean ........ Keeled .... do ..

Nicobal Isles ......... Spotted ... do ..

Mediterranean, Guinea.. Banded.... do..

Tranquebar ......... Milky .... do ..

Britain............. Ashy .... do ..

Britain ............. Foolish .... do ..

New Jersey .......... Great.... do ...

............... Agate.... do..

Britain ............. Triangular do..

.................. Minute ... do ..

Ceylon .............. Donax .... do ..

FAMLLY 2.-Having a striated or wrinkled surface.

Striatula ..... W. Indies, Mediterrancan Striated ... do .. Plicataria ...... Indian Ocean ......... Plaited .... do .. Papyracea ...... Nicobar Isles ......... Paper .... do . Vitrea ........ Ceylon ............ Brittle ... do .. Cygnea ....... Tranquebar .......... Swan .... do .. Turgida........ Ditto.... . ........ Inflated ... do .. Violacea ........ Ditto.............. Violet .... do .. Cuneata ....... Ditto ............. Wedge.... do .. Rotundata .... ................. Roundish .. do .. Glabrata ...... African Ocean ........ Smooth ... do .. Nitida ...................... Delicate... do .. Striata..................... Striated ... do .. Radiata....... Britain ........... Rayed.... do.. 
Scientific Name.

Solida

Solidissima ......

Truncata

Subtruncata.....

Australis

Piperata

Tenuis ..........

Boysii .........

\section{Locality.} Britain ............ Strong Mactra ..

North America ........ Thick .... do .. Britain.............. Truncated. do .. Britain .............. Abrupt.... do .. New Zealand ......... Southern .. do .. Mouth of the Niger...... Pepper.... do . Britain .............. Thin ..... do .. Ditto............... Boys'.... . do ..

\section{Drvision II.-Shell ovate, oblong.}

Famisy 1.-Closed at both ends.

Glauca ........ Spain and Britain ..... Red rayed - do . Rugosa....... Mediterranean, Nicobar. Rugged.... do .

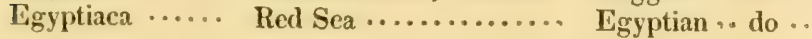

FAMILY 2.-Gaping at the anterior end.

Pellucida ..... Guinea............ Pellucid . . do .. Fragilis....... Britain, Nicobar...... Brittle .... do .. Listeri ....... Britain .......... Lister's... do ..

FaMiLY 3.-Gaping at both ends.

Planata....... Tranquebar, Britain .... Flattened.. do .. Lutraria ........ Britain ........... Muddy.... do .. Hians..... Ditto ............. Gaping... do .. 



\section{DONAX._WEDGE-SHELL.}

\section{DESCRIPTION OF PLATE IX.}

Div. I.-Fig. 1. D. scortum.
Div. II.-Fig. 4. D. denticulata. Drv. III.-Fig. 3. D. madagascariensis.
Fig. 5. D. trunculus. Dtv. IV.-Fig. 2. D. scripta.
Fig.6. D. elongata. Fig. 7. D. stultorum.

Shell bivalve, with generally a crenulated margin, the frontal margin very obtuse; linge with two teeth, and a single marginal one placed a little behind, rarely double or triple.

THE principal characteristic of the Donax is derived from its form, which (throughout its twenty-four species) is similar to that of a wedge, being very broad and thick at one extremity, and gradually tapering towards the other. The margin, which is generally of a deep color, is almost invariably crenulated or beset with small contiguous teeth; and the frontal margin is generally very obtuse: the anterior slope not unfrequently gapes, and has a ligament situated near the fissure, which prevents the two valves from separating, when the animal has occasion to open them.

Some specimens of this genus, in their external appearance, bear a strong resemblance to the species of the Venus; but the examination of the hinge will always determine to which of the genera the shell belongs.

The Donax presents so great a diversity in external character, that it has occasioned the genus to be separated into five divisions. In the first, the species exhibit a rough and decussated surface, caused by crowd- 
ed strix, crossing each other in a transverse and longitudinal direction, thus giving the shell a spiny appearance, as in the D. scortum and D. pubescens. The second and third divisions are also characterized by the position of the strix, which in the one are longitudinal, and in the other transverse. The shells of the fourth division have a smooth and polished surface; and the fifth at present consists of one species only, which has its surface partially covered with transverse membranaceous ridges.

The most prevailing color is a rich purple, which sometimes only appears in rays on a white ground, diverging from the beaks to the margin. Many of the species are of an olive-yellow tinge, which often inclines to a bright orange; and others, again, have a pink hue, finely diversified with brown zigzag markings, as in the D. scripta, \&c. and in some instances the shells are variously banded. The interior almost always partakes of the coloring of the exterior.

It is doubtful whether any shells of this genus are uatives of rivers, as they are generally found buried in the sand of the sea shore. Although the species and varieties are but few, and thinly scattered over most parts of the globe, yet some coasts (the European in particular) supply a profusion, but of no great variety.

The Donax derives its name from its shape, which resembles the barbed head of a javelin or dart (Sóva $)$. 


\section{Drvision I.-With decussated and muricated stria.}

Scientific Name.

Scortum ........

Pubescens.......

Muricata .......

Spinosa........
Locality.

Ceylon, East Indies

Amboyna

Indian Ocean 0.0 .0$.

Tranquebar............
Common Name.

Beaked Donax...

Spiny ..... do ...

Prickly.... do ...

Spinous.... do ..

\section{Division II.-Longitudinally striated.}

\begin{tabular}{|c|c|c|}
\hline Rugosa ........ & $\begin{array}{l}\text { South Sea, Mouth of the } \\
\text { Niger, Mediterranean. }\end{array}$ & \\
\hline Serra.......... & Tranquebar, C. G. Hope. & Crenated.. do . \\
\hline Frunculus ..... & $\begin{array}{c}\text { Great Britain, Mediterra- } \\
\text { nean, West Indies .... }\end{array}$ & Com \\
\hline & Jamaica, Mediterranean . & Striated... do \\
\hline Denticulata .... & $\begin{array}{r}\text { Mediterranean, Africa, } \\
\text { Great Britain ........ }\end{array}$ & Tor \\
\hline & Tranquebar ............ & \\
\hline gata..... & Red Sea............... & Elongated · do \\
\hline
\end{tabular}

Division III.-Transversely striated.

Plebeia ........ Dorsetshire .......... Horn color'd do..

Castanea ....... West of England ...... Chesnut ... do ..

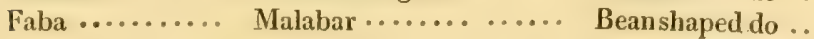

Straminea ................... Straw color'd do .

Candida ....... Tranquebar.......... White.... do ..

Radiata ....... Ditto............. Rayed .... do ..

Cuneata ....... Ditto, East Indies...... Wedge.... do ..

* Madagascariensis Madagascar......... Madagascar do.. 


\section{Division IV.-Smooth.}

\begin{tabular}{|c|c|c|}
\hline Scientific Name. & Locality. & Common Name. \\
\hline Complanata.... & Germany, Great Britain. & Single rayed D. . . \\
\hline savigata .... & Tranquebar............ & Smooth ... do .. \\
\hline Scripta..... & E. Indies, Mediterranean & Lettered... do .. \\
\hline Stultoru & Indian Seas $\ldots . . . \ldots$ & Foolish.... do \\
\hline
\end{tabular}

Drvisior V.-Shell with transverse membranaceous ridges.

Irus ......... Britain, Meditciranean .. Ragged.... do ... 


\section{VENUS._VENUS。}

DESCRIPTION OF PLATE $x$.

Drv. 1. -Fig. 1. V. dione.

Drv. II.-Fig. 2. V. ornata.

Fig. 5. V. ovata.

Fig. 6, V. flexuosa.
Drv. II. -Fig. 8. V. pectunculus.

Div. III.Fig, \%. V. scripta.

Drv. V.-Fam. 1. Fig. 4. V. literata.

Fam. 1. Fig. 3. V. palustris.

Shell bivalve, the frontal margin flattened, with incumbent lips: hinge with three approximate teeth, the lateral ones diveryent at the tip.

IT has already been observed, that this genus, with regard to beauty, surpasses the other genera of Bivalves. It contains no less than one hundred and fifteen species.

The divisions of the Venus are also very numerous, and are distinguished by a much greater variety of form, (as the elongated, compressed, angular, and orbicular,) than is to be observed in any other genus of this order.

Notwithstanding this great diversity of formation, there is one leading feature which is observable in most of the species, viz. the flatness of the frontal margins, and the lips being often incumbent; but the surest guide in the classification of these shells is the hinge, which, with scarce any exception, contains three teeth, all approximate; in addition to these, there is a lateral tooth, not infrequently divergent at the tip. The interior margin of the shell is sometimes crentlated; and a few of the species, though rarely, gape.

In many specimens the exterior surface is covered 
with longitudinal or transverse strix, sometimes with both, which not unusually terminate in foliations near the margins.

The coloring of the exterior, as well as the interior, is of almost every possible shade; and sometimes of the most beautiful and lively tints.

Specimens of this genus are found in most parts of the world.

Divisron I.-With the anterior depression spinous.

Scientific Name.

Dione ..........

Marica
Locality.

S. America, West Indies,

Brazil, Trinidad ..... Spined Venus .. American Seas, W. Indies American.. do ..

\section{Division II.-Subcordate.}

Many species of this division, as the V.erycina, $V$. maculata, $V$. chione, \&c. are remarkable for the smoothness and brilliant lustre, as well as the high and rich coloring of their surfaces; and others, as the V. paphia, V. reticulata, \&c. though inferior in color and polish, are nevertheless much admired on account of the beautiful reticulations with which they are ornamented. The V. mercenaria, which in fine specimens is of a rich purple, forms the wampum or money of the North American Indians.

Scientific Name.

Paphia .........

Fasciata
Locality.

IV. Indies, Mediterranean Great Britain, W. Indies
Common Name.

Paphian Venus.. Thick ribbed do . 
BIVALVES - VENUS.

Scientific Name.

Succincta .......

Cingenda .......

Dysera.........

Tiara...........

Plicata .........

Excavata .......

Spinifera .......

Verrucosa .....

Rigida..........

Casina .........

Cancellata ......

Subcordata ......

Minima ........

Sulcata........

Montagui .......

Scotica........

Danmonia ... ..

Reflexa .....

Gallina .........

Circinata.......

Caliste .........

Compressa......

Exalbida........

Petulca

Granulata ......

Ovata........

Paupercula....

Flexuosa........

Mactroides ......

Tripla ..........

Triangularis ....

Malabarica......

Flammea ......

Erycina.........

Costata......

Pacifica ........

Mercenaria .....

Islandica . . . .

Coaxans.......
Locality.

W. Indies, Frith of Fortl

Americau \& Asiatic Ocean

East Indies ...........

Levant Sea ............

Great Britain ..........

Devonshire ...........

G.Britain, Mediterranean

West Indies, Brazil ... .

Great Britain .........

East and West Indies ...

Falmoutlı Harbour .....

Coast of Scotland .......

Ditto ................

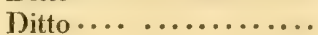

Devonshire ...........

...................

Mediterranean, Norway, Great Britain ... ....

Guinea, Frith of Forth..

Red Sea ..............

n..................

Falkland Isles .........

South Coast of Europe . .

West Indies, Great Britain

Great Britain ..........

Coromandel ..........

West Indies...........

Guinea, West Indies ....

Africa, Mouth of the Niger

Coast of Devonshire ....

Malabar...............

Red Sea .............

Europe, East Indies ....

Ceylon - .............

South Seas, China......

North America, Norway Iceland, Great Britain. .

Rivers in Ceylon .......
Common Name.

Grooved Venus..

Girdled ... do ..

Ribbed.... do ..

Turban.... do ..

Plaited .... do ..

Excavated. do..

Spiny .... do ..

Warty .... do ..

Rigid ..... do ..

Broad-ribbed do .

Channeled. do ..

Subcordate do..

Redstreaked do ..

Furrowed - do ..

Montagu's - do ..

Scottish ... do ..

Devonshire do..

Reflected .. do ..

Hen .... . do ..

Compass .. do ..

Dirty white do ..

Compressed do ..

Whitish ... do ..

Clouded... do ..

Grained ... do ..

Oval ...... do ..

Despised... do ..

Flexuous .. do ..

Mactra ... do ..

Triple .... do ..

Triangular do..

Malabar .. do ..

Brown band do ..

Polished .. do ..

Ribbed ... do ..

South Sea - do ..

Money .... do ..

Icelandic .. do ..

Ceylon... do .. 
Scientific Name.

Lusoria

Chione

Maculata.......

Casta

Meretrix.......

Paradoxa .......

Læta..........

Pinguis

Triradiata......

Nebulosa........

Exilis ..........

Recens........

Japonica........

Striata........

Castrensis.......

Pectunculus.....

Lorenziana......

Ornata.........

Phryne.......

Meroe .........

Callipyga .......

Deflorata.......

Fimbriata.......

Reticulata......

Puerpera.......

Crenulata.....

Radiata........

Cincta ..........

Squamosa.......

Lapicida .......

Divergens ......

Plumbea......
Locality.

Amboyna, China .......

Asiatic Ocean, Mediterranean, Great Britain.

West Indies, Brazil, New

S. Wales .........

East Indies . . .......

Indian Seas, Mouths of

Rivers in Ceylon ......

Coast of Peru ..........

Mediterranean,Indian seas

East Indies . . . . . . . . . .

Tranquebar ............

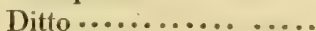

Malabar ............

Coromandel ........

Japan ..............

Nicobar Isles ..........

East and West Indies...

Red Sea, East Indies ....

Ceylon ..............

Tranquebar, Mauritius ..

So. Ocean, Persian Gulf .

East Indies, Brazil . . . . . .

Red Sea .............

GreatBritain, WestIndies,

Mauritius

E. Indies, Pacific Ocean.

Tranquebar, N. S. Wales

Fast Indies, China......

Ditto, Campeachy ......

.....................

.....................

Amboyna.............

West Indies, in corals....

Ditto

New Zealand ........
Common Name.

Sportive Venus .

Smooth brown do

Spotted ... do ..

Chaste ... do ..

Lipped .... do ..

Doubtful .. do ..

Globose... do ..

Sleek ..... do ..

Three rayed do ..

Clouded .. do ..

Abandoned do ..

Recent.... do..

Japanese .. do ..

Striated ... do ..

Camp .... do ..

Painted.... do ..

Lorenzo... do ..

Adorned... do ..

Phryne... do ..

Meroe..... do ..

Arabian ... do ..

Purple streaked..

Fringed ... do ..

Netted .... do ..

Spotted ... do .

Crenulated do..

Rayed..... do..

Girdled .. do ..

Scaly .. . do ..

Rock .... do ..

Ziczac ... do ..

Leaden.... do.. 
Drvision III,-Sub-orbicular.

Scientific Name.

Tigrina

Sinensis.

Prostrata.......

Punctata......

Excisa..........

Exoleta..........

Concentrica.....

Juvenis

Histrio

Undata ........

Tumidula .......

Borealis

Aculeata.......

Pectinata......

Discors .........

Dispar.........

Equivoca

Divaricata

Contraria

Corrugata

Scripta........

\section{Locality.}

West Indies, Britain ... .

China..............

Tranquebar..........

New South Wales....

Tranquebar........... Jamaica, Great Britain. .

North America, Jamaica,

Brazil

East Indies...............

Ditto................

Coast of Britain ........

Coast of Europe ........

Coast of Europe o.

Amboyna, South Sea...

Mauritius, China ......

South Sea ...........

East Indies ...........

Ditto

Guinea, West Indies....

Red Sea.............

Amboyna, Naples, S.Seas
Common Name.

Tiger Venus ..

Chinese... do ..

Compressed do..

Punctured - do ..

Defaced ... do ..

Antiquated do..

Concentric do.. Young.... do .. Party colored do . Waved .... do ..

Gibbous... do .. Northern .. do .. Acute ribbed do. . Pectinated. do .. Toothed ... do .. Unequal... do .. Equivocal - do .. Divaricated do .. Contrary .. do .. Corrugated do.. Written... do..

Drvision IV. - Shells inflected with a longitudinal furrow on the anterior end.

Pensylvanica.... Pensylvania, West Indies. Pensylvanian do.. Edentula ...... Jamaica, St. Croix ..... Toothless .. do .. Jamaicensis .... Jamaica ............ Jamaica .. do .. Spuria......... Britain, Mediterranean .. Spurious .. do .. Globosa...... Red Sea........... Globose... do .. 
Division V.-Shells sub-oval, and slightly angulated on the anterior side.

FAMILY 1.-Smooth or striated.

Scientific Name.

Gigantea....... Florida, Antigua

Literata ...... Amboyna............

Geographica .... Mediterranean .......

Rotundata ...... Indian Ocean, Ceylon ..

Undulata ...... East Indies, Mediterranean, Red Sea ....... Undulated . do .

Obsoleta....... Mediterrancan........ Obsolete . do ..

Decussata ..... Indian Ocean, Great Britain, Mediterranean ... Intersected. do ..

Senegalensis ... Senegal ......... Senegal ... do . Perforans ..... Plymouth, in limestone.. Piercing .. do .. Virginea..... East and West Indies, Great Britain, Adriatic Virgin .... do . .

Aurea ........ Great Britain .........

* Palustris......

Monstrosa.......
Golden... do .. .......... do do.

Distorted.. do ..

\section{Famror II.-Foliated.}

Agaracoides..... New Holland.......... Mushroom.. do .. 
BIVALVES - SPONDYLUS.

SPONDYLUS._Thorny OYSTER or ARTICHOKE:

DESCRIPTION OF PLATE XII.

Dr. 1.-.-Fam. 1. Fig. 1. S. gædaropus..-.Fig. 4. rariety.

Drv. I1...Fam, 1. Fig. 3. S. anacanthus. Fam.2. Fig.2. S. plicatus.

Shell hard, solid, with unequal ralves; one of the valves convex, the other rather flat: hinge with two recurved teeth separated by a small hollow.

THIS genus, though presenting innumerable varieties, contains only ten distinct species, and these, from their extreme irregularity of formation, and great similarity of appearance, may often be confounded with each other.

The most striking character of the Spondylus is, that its valves, which resemble those of the common oyster, have their outsides covered with longitudinal rows of erect spines or ramifications. The spines are usually round, and terminate in a point; the ramifications or branchings, on the contrary, are flat, and have jagged and patulous extremities. These peculiarities form the distinctions of the two families of the first division. Many species possessing these characters are also concentrically plaited on the lower valve. The second division is distinguished by its species being longitudinally striated or plaited.

The hinge is furnished with two recurved tecth, which are very strong and articulate, and separated by a small but deep hollow; the immer margin is usually crenulated, and highly colored with orange or purple. The lower valve generally protrudes much beyond the upper, 
and terminates in a curved and lengthened beak, which in most of the genus has ears on each side.

The usual colors are orange, red, purple, white, or brown, two of which are often blended in the same shell.

The Spondyli are met with in the American, Indian, Mediterranean, and other seas, adhering to rocks, corals, \&c. in groups, often forming large masses; others are also found attached to shells.

This genus has been named Spondylus, from the resemblance which sonte of its species bear to the head of

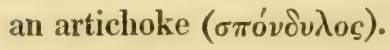

Division I.-Shell armed wath spines ov ramifications.

Famizy 1.-Sharp spines.

Scientific Name.

Locality.

Common Name.

Gædaropus...... Amboyna, West Indies.. Thorny red Spon.

Regius........ India ............. Royal .... do ..

Aurantius...... Mauritius........... Orange.... do ..

Citrinus........ East Indies .......... Yellow .... do ..

Histrix ....... Indian Seas ........ Hedgehog . do ..

Family 2.-Having palmated or foliated ramifications.

Palmatus ...... .................. Palmated .. do .

Spathuliferus.... ................. Pied .... . do ..

Ducalis ........................ Ducal.... do ..

Drvision II.-Shell unarmed.

Famrux 1.-Upper valve longitudinally striated.

Anacanthus..... Indian Seas .......... Spineless .. do ..

Fампт 2.-Valves longitudinally plaited.

Plicatus....... West Indies......... Plaited.... do .. 


\section{CHama._Clamp, Clam, or Gaper.}

\section{DESCRIPTION OF PLATE XII.}

Dr. 1.F Fam. 1. Fig. 1. C. gigas. Fam. 1. Fig. 2. C. hippopus. Fam. 2. Fig. 4. C. antiquata. Fam. 2. Fig. 5. C. rosea.
Fam. 3. Fig. 6. C. concamerata.

Fam. 6. Fig. 3. C. cor.

Drv. II.Fig. 7. C. gryphoides.

Fig. 8. C. arcinella.

Shell bivalve, rather coarse; hinge with a callous gibbosity, obliquely inserted in an inclined hollow; anterior slope closed.

THIS genus contains only twenty-seven species, but presents considerable diversity in character. It comprehends species the most dissimilar in form and magnitude, and some as remarkable for their symmetry as others are for their deformity.

It would be difficult, with the exception of the callous gibbosity of the hinge, to point out a distinction by which the shells of this genus might be recognised. The forms it exhibits are the suborbicular, reniform, cordate, and rhombic. The posterior slope gapes only in the $\mathbf{C}$. gigas and $\mathbf{C}$. hippopus, (and not always in the latter), but the anterior is universally closed, and the margin crenulated. Almost all the species are equivalve, and many of them are inequilateral. The exterior is usually ribbed or striated longitudinally; it is also scaly, or tuberculated; some specimens are richly foliated or spined; and others are nearly smooth.

There are two formations of the Chama which deserve particular notice, viz. the cordiform and concamerated. The first is exhibited in the C.moltkiana and C. cor, which 
bear a striking resemblance to a heart, excepting that the valves terminate in a graceful curve towards the hinge. The other is exemplified in the C. concamerata, which has, in the interior of each valve, an ovate chamber.

The species which compose the first division are detached; and those of the second aflix themselves to other substances, as rocks, stones, shells, \&c.

The colors are extremely various, sometimes elegantly blended. Of the $\mathrm{C}$. arcinella and $\mathrm{C}$. gigas the pink varieties are most valued by collectors.

The most rare species are the $\mathrm{C}$. moltkiana, C. semiorbiculata, and C. concamerata.

The American, Indian, and Atlantic Oceans, and the Mediterranean, Caspian, and Adriatic Seas, produce numerous varieties of the genus.

The Chama is named from the gaping ( $\left.x^{\prime} \mu \eta \eta\right)$ observable in two of its species.

\section{Division I.-Shell equivalve.}

The C. gigas is the largest shell in the order of testacer; the valves sometimes exceed four feet in length, and are of the enormous weight of five hundred pounds. So disproportionate are the varieties of this species, that specimens have been found measuring only half an inch. The cartilage of the hinge, which is of a dull brown color, when cut and polished, is so beautifully irridescent, that it even rivals the opal.

This species occasionally produces large and costly pearls. 
Famru 1.-With longitudinal ribs, gaping at the posterior slope.

Scientific Name.

Gigas ........ Red Sea,Ambayna, China,

New Holland ........ Giant Clam ....

Hippopus ...... East Indies, Amboyna,

China ............ Spotted... do ..

Famry 2.-With longitudinal vibs, posterior slope closed.

Antiquata...... Mediterranean, Gibraltar Antiquated do ..

Ajar.......... Mouth of the Niger,

Tranquebar .......... Ajar...... do ..

Trapezia ...... Norway.............. Trapeziform do ..

*Rosea ........ West Indies ........... Rose color'd do ..

Calyculata..... East Indies, Mediterranean, Senegal...$\ldots \ldots$ Variegated do..

Pectunculus ..... .................. Pectuncle.. do ..

Satiata.......................... Obsolete... do ..

Rugosa......................... Rugged.... do ..

FaмrL 3.-Shell longitudinally ribbed, having an ovate chamber in the interior of each valve.

Concamerata .... Cape of Good Hope..... Chambered do ..

Faminy 4.-Shell decussated or transversely striated, without ribs.

Semiorbiculata .. Arabia ............. Brown .... do ..

Cordata........ Ditto .............. Heart-shap'd do..

Oblonga ........ Guinea, Pulo Condore .. Oblong.... do ..

Coralliophaga... East Indies, in coral .... Coral .... do ..

\section{FamiLy 5.-Shell tuberculated.}

Plumbea....... South Seas........... Leaden.... do .. E 2 
Famry 6.-Heart shaped, umbones prominent and apices spirally recurved.

Scientific Name.

Cor

Moltkiana
Locality. Mediterranean, France, Bantry Bay ......... Heart Clam China
Common Name.

Moltkian's.. do ..

Divisron II.-Shell inequivalve.

Lazarus........ Mediterranean, West Indies, China ........ Lazarus .. do ..

Gryphoides .... East \& West Indies, Medi. terianean, Africa ..... Gryphus .. do ..

Cornuta ....... Mediterranean........ Horned.... do ..

Sessilis......... W. Indies, Mediterranean Scaly..... do .. Lamellosa....... .................. Lamellar .. do .. Punctata....... Guadaloupe.......... Dotted .... do .. Sinistrorsa...... East and West Indies.... Reversed .. do .. Arcinella....... Ditto, Brazils ......... Hedgehog . do .. * Ponderosa .... South Seas ............ Heavy.... do .. 


\section{ARCA.-ARK.}

\section{DESCRIPTION OF PLATE XIII.}

Dir. I. Fam. 1. Fig. 1. A.tortuosa. Drv. II. Fam.2. Fig.6. A. pectunculus.

Fam.2. Fig. 4. A. lactea.

Fam. 5. Fig. 2. A. barbata.
Fam.2. Fig. \%. A.glycymeris.

Fam. 4. Fig. 3. A. granosa.

Drv. III. Fig. 5. A. nucleus.

Shell bivalve, equivalve; linge with numerous sharp teeth, alter. nately inserted between each other.

THE genus Arca, of which there are forty-one species, is easily distinguished from other genera of Bivalves by the peculiarity of the hinge; which, without any exception, is composed of numerous sharp teeth, alternately inserted between each other. The line of direction of the hinge is in some species perfectly straight, and in others it is arched or curved. These characters form the distinctions of the first and second divisions.

The forms of the Arks vary exceedingly: the elongated is exemplified in the A. tortuosa, A. nox, and A. barbata, \&c.; the suborbicular in the A. glycymeris, \&c. (which are nearly smooth on the outside, and have the inner margin generally crenated); and the subcordate, in the A. senilis, \&c. which are also somewhat gibbous, and have usually smooth or muricated grooves. The shells of this genus are covered with a brownish or greenish-black epidermis.

Many of the Arks gape at the superior margin; others, on the contrary, are perfectly close. Some have the margin entire, others are crenulated, and several have 
the slopes prominent and angular, giving the shell an eared appearance; but the anterior slope is far the most prominent.

The A. concamerata, and A. tortuosa, are the most rare species of this genus.

The Arcs are found in the European, Indian, American, and Atlantic oceans; the Baltic, Northern, and Red seas also produce some species.

Drvision 1.-With the teeth of the hinge in a straight line.

\begin{tabular}{ccc}
\multicolumn{3}{c}{ FamiLY 1.-Shell twisted. } \\
Scientific Name. & Locality. & Common Nume. \\
Tortuosa........... Amboyna, Red Sea .... & Twisted Ark ...
\end{tabular}

FAMILY 2.-Shell rhomboidal.

Noæ.......... E. \& W. Indies, Britain . Noah's.... do ..

Imbricata....... W.Indies, G. Britain, Mediterranean, C.G. Hope Imbricated - do ..

Navicularis..... St. Domingo........... Boat...... do ..

Plicata......... Red Sea.............. Plaited .... dò ..

Candida ........ West Indies, Guinea..... White .... do..

Indica ......... Coromandel.......... Indian ... do ..

Lactea......... Britain, Mediterranean .. Milky .... do ..

Reticulata...... West Indies ........... Reticulated do..

FAMILY 3.-Shell oblong or transversely ovate.

Magellanica ..... Straits of Magellan .... Magellanic. do ..

Lacerata...... East Indies .......... Hairy ..... do ..

Fusca ......... West Indies, Madagascar Brown .... do ..

Bicolorata...... Red Sea.............. Party-color'd do

Modiolus....... Mediterranean, W. Indies Muscle.... do ..

Corbula........ Nicobar Isles, C. G. Hope Basket .... do ..

Senegalensis..... Mouth of the Niger..... Senegal ... do .. 
FamiLY 4.-Shell subcordate.

Scientific Name.

Locality.

Common Name.

Lrevigata ...... Nicobar Isles ......... Smooth Ark ..

Pella......... Mediterranean, Spain ... Brittle .... do ...

Antiquata...... E. \& IV. Indies, Africa .. Antiquated. do ..

Granosa ....... China, East Indies ..... Grained ... do ..

Rhombea...... E. \& W. Indies, Brazil .. Rhomboid. do ..

Senilis ........ Guinea ............ Rugose.... do ..

\section{Famis 5.-Gaping.}

Complanata.... Guinea, Madagascar .... Compressed do ..

Barbata....... Mcditerranean, Red Sea. Bearded.... do..

Nivea ....... Red Sea............ White... do .

Cancellata..... Curacoa............. Cancellated do .

Famru 6.-- I With an ear-shaped appendage in the interior of each valve.

Concamerata ... Nicobar Isles ........ Chambered do..

Drvision 1I.-With the teeth of the hinge in a curved line.

Famiry 1.-Subcordate.

Campechensis ... Campeachy, Carolina.... Campeachy do .. Equilatera ..... West Indies......... Equilateral do .. Angulosa....... W. Indies, Brazil, Africa Angular... do ..

FAMILY 2.-Suborbicular, margins crenated or plaited.

Pectunculus..... South America, Red Sea. Mottled ... do ..

Pectinata....... West Indies.......... Pecten .... do..

Decussata...... East \& West Indies .... Decussated do.. 
Pallens ........ India ............... Pale Ark.....

Undata........ W. Indies, Mediterranean Waved.... do ..

Glycymeris..... Red Sea, Guernsey, Mediterranean, Britain ..... Orbicular . do ..

Pilosa ....... . Mediterranean, Great Britain, Spain ......... Downy . .. do ..

Stellata ........ Portugal, Africa ....... Starred.... do ..

Scripta........ St. Domingo ......... Lettered .. do ..

Nummaria...... Mediterranean, Spain... Coin ...... do..

FAMrLY 3.-Suborbicular, margin entire.

Multistriata.... Red Sea ............. Manystriped do..

Divisyon III.-With the teeth of the hinge produced and sharply pointed.

Nucleus........ Britain, Mediterranean,

St. Domingo ......... Silvery .... do ..

Rostrata....... Norway, Scotland ..... Beaked.... do ..

Minuta ....... Baltic, Britain......... Minute... do ..

Tenuis......... Dunbar, Leith Roads... Thin ..... do .. 


\title{
OSTREA._Oyster, Scallop, or Pecten.
}

\section{DESCRIPTION OF PLATE XIV.}

\author{
Drv. I. - Fam. 1. Fig. 2. O. ziczac. \\ Fam. 4. Fig. 1. O. pleuroneetes. \\ Drr. II.-Fam. 1. Fig. 4. O. varia. \\ Fam. 2. Fig. 6. O. obsoleta: \\ Drv. IV.-Fam. 2. Fig. 5. O. folium. \\ Div. V. - Fig. 3. O. isognomon.
}

Shell bivalve, generally with unequal valves, and slightly eured;

hinge without teeth, but furnished with an ovate hollow, and usually with lateral transverse grooves.

THERE are no less than eighty-eight species in this genus, which present considerable variety in beauty and form.

The Ostrex are divided into several classes: the first and second (which are the most important) comprise the innumerable varieties of escallops or scallop shells, and are distinguished from each other by the proportion of their ears. The first is, for the most part, composed of very elegant species; their form is usually regular, and their surface is adorned with elevated divergent ribs, varying in number fiom five to forty, which proceed from the tip of the beaks to the extremity of the margins, there terminating in a scalloped outline.

The Scallops are usually equivalve, but a few, as the O. ziczac, O. jacobæa, and others of the same fanily, have invariably the upper valve flat, and the lower convex.

It is remarkable, that in many of the Scallops the colors 
of the upper valve are brighter than those of the lower, as may be particularly observed in the 0 . pleuronectes, which has one valve perfectly white, and the other of a brownish or reddish cast.

The beaks of the Scallops often vary considerably in position; some, as the O. maxima, O. jacobra, \&c. have them placed in the centre; while, in the 0. lima, O. glacialis, \&c. they are situated obliquely or on one side, which gives the outline of the shell an appearance of slight distortion, occasioned by one margin being straight and flattened, and the other round and inflated.

There is also considerable variation in the size and form of the ears, which in some species are nearly of the same dimensions, but in others are unequal; and some are so small as hardly to be discernible.

The ribs are variously diversified with beautiful colors, and delicate chequer-work; they are usually covered with undulated and transverse strix, not unfrequently assuming the appearance of elevated scales, as in the O. imbricata and $\mathrm{O}$. dubia. In others the striæ are crenated, as in the O. radula; and some, as the O. nodosa, \&c. have large knobs or tubercles raised upon the ribs. The margins of the interior of the Scallops are mostly crenated, and are often beautifully colored.

The hinge is universally without teeth, and is furnished with an ovate hollow; in the vicinity of which are placed lateral transverse grooves, which rum in a parallel direction in either valve, but do not lock into each other, as in the genus Arca.

The Scallops have the faculty of leaping out of the water, and are enabled to effect a very rapid motion by opening and closing their valves. 
These shells were formerly worn by pilgrims, on their hat or coat, as a mark of their having crossed the sea, for the purpose of paying their devotions at the holy shrine in Palestine: in commemoration of which they are still preserved in the armorial bearings of many families of distinction, whose ancestors had performed that ceremony.

The third and remaining divisions of Ostreæ consist of those which in construction, substance, and coloring, are more nearly allied to the common or eatable Oyster. The species are generally of a more irregular form than the Scallops. They are rough and plaited on the exterior, but the interior is smooth and glossy, and some of them have a steel-blue color or metallic lustre diffused over the surface. The most remarkable species of the third division is the 0 . malleus; in form it resembles a pick-axe: there are two varieties of it, viz. the white and the black, both of which, when in fine preservation, are highly esteemed, but the white variety is much more rare and valuable. Some species have the appearance of a dried leaf, as the $\mathrm{O}$. folium and others of the fourth division; these are parasitical, and often attach themselves to the roots and stumps of trees.

The hinge of a few of the species, as the $O$. perna and O. isognomon, has a perpendicular grooved line. Some, as the 0 . vulsella, \&c. gape at the hinge; others terminate in a long beak from the hinge upwards, as the $O$. cornucopire and $\mathrm{O}$. virginica.

The shells composing the third family of the fourth division, have been removed from the genus Mytilus to that of the Ostrea, to which they bear a much stronger resemblance. 
Varieties of Ostreæ are found in almost every part of the world, but the most rare in the Indian seas; among which may be mentioned, the varieties of the 0 . malleus, $\mathrm{O}$. pallium, and $\mathrm{O}$. spondyloides.

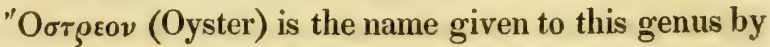
the antient naturalists.

Division I.-Valves with ears equal.

FamiLY 1.-Valves ribbed, upper valve fat.

Scientific Name.

Maxima ........ European Seas ........

Jacobæa........ Britain, Mediterranean..

Ziczac.......... West Indies, Red Sea....

Striatula....... Indian Ocean..........

Minuta.......
Common Name. Greatest Scallop Lesser..... do .. Zigzag .... do .. Sixteen rayed do. Minute.... do ..

FAMILY 2.-Valves ribbed, ears equal.

Hybrida ....... Norway............ Hybrid.... do .. Radula ....... Amboyna, China ..... Rasp..... do .. Imbricata...... Red Sea............. Imbricated do .. Plica .......... Amboyna, Indian Ocean. Folded .... do .. Hians ........ Norway.............. Gaping... do ..

FamiLY 3.-Valves flattish on one side and gaping.

Lima........ Ceylon, Mediterranean, Red Sea ........... File...... do ..

Vasciata ....... Britain, West Indies, Cape of Good Hope ........ Banded .... do ..

Bullata ........ Mediterranean......... Swollen ... do ..

Fragilis........ Nicobar Isles... ...... Brittle .... do .

Scabra ....... West Indies .. ........ Rough .... do .. Glacialis....... St. Domingo, Mediterran. Icy ...... do .. Excavata ...... Norway ............ Hollow ... do .. * Loscombia.... Devonshire ........... Loscomb's . do .. 
FAMILY 4,-Valves smooth or striated, and not closing.

Scientific Name.

Pleuronectes.....

Japonica.......

Magellanica.....

\section{Localaty.}

Amboyna, Moluccas .... Sole Scallop...

China, Japan .......... Japanese .. do .. Magellan ............ Magellanic do ,.

Division 11.-Valves with unequal ears.

FamiLY 1.-Valves ribbed.

Pes-lutræe.......

Pallium..........

Sanguinolenta...

Palliata.........

Nodosa .........

Pes-felis.........

Sulcata.........

Cinnabarica ....

Senatoria .......

Citrina .........

Pellucens

Obliterata.......

Sanguinea ......

Porphyria.......

Varia...........

Sauciata........

Pusio ...........

Sinuosa ........

Miniata ........

Triradiata .......

Solaris........

Glabra .........

Opercularis.....

Lineata .........

Nucleus.........
. Otter's foot do .. Amboyna, China ....... Ducal mantle do. Red Sea ............. Red spotted do .. Mediterranean ......... Variegated. do .. Africa, E. \& W. Indies .. Knobbed .. do .. Africa, Mediterranean .. Cat's foot .. do .. ................... Sulcated .. do .. Norway, Britain, America Red ...... do .. Moluccas ........... Senator.... do .. Indian Seas .......... Yellow.... do .. West Indies ........... Pellucid... do .. Moluccas, South Europe Worn ..... do... W. Indies, South Seas - Scarlet.... do .. Red Sea.............. Porphyry.. do .. Britain, Mediterranean .. Variegated do. Red Sea............. Unequal rayed do Nicobar Isles .......... Wrinkled.. do .. Britain ............. Distorted .. do .. ................... Vermilion.. do .. Norway, Denmark...... Three rayed do .. Adriatic ............ Solar..... do .. Mediterranean, Portugal. Glabrous - do .. Britain, America ....... Painted.... do .. Britain ............ Line.... do .. East Indies........... Kernel .... do .. 
Scientific Name.

Gibba........ South America, Africa,

West Indies ......... Gibbous Scallop

Turgida........ East \& WestIndies ..... Turgid.... do ..

Pyxidata ....... Malabar............ Box-like... do ..

Flavicans....... Southern Occan...... Yellow .... do ..

Fanicy 2.-Valves smooth.

Tigrina ...... Denmark ........... Tyger .... do ..

Fuci ......... Denmark ........... Fucus .... do ..

Exotica....... Red Sea ............ Exotic .... do ..

Vitrea....... Norway ........... Glassy .... do ..

Obsoleta...... Britain.............. Obsolete.. do ..

Lævis ....... Ditto .............. Smooth ... do ..

Proteus........ Mediterranean......... Variable .. do ..

\section{Drvision III.-Oblong, linear.}

FAMrLY 1.-With a transverse lobe on each side of the hinge.

Malleus........ Pulo Condore, South Seas,

Ceylon........... Hammer Oyster

FAMILY 2.-With a slight beak on one side the hinge.

Figurata...... Nicobar Isles ........ Figured ... do ..

FamiLy 3.-Rounded at the hinge.

Regula........ Red Sea ........... Tongue shap'd do

FAMILY 4.-Valves diverying at the hinge, and the inside vaulted.

Fornicata...... Red Sea.......... Vaulted ... do .. 
Divisron IV.-Parasitical, or attached to other substances.

Famis 1.-With one valve produced at the summit.

\section{Scientific Name.}

Cucullata .......

Virginea.......

Rostrata.

Forskalii ........

Cristata.........

Sinensis
Locality. Africa, Arabia, So. Seas . Hooded Oyster .. Virginia ............. Virginian... do .. Mediterranean......... Beaked.... do .. Coast of Egypt......... Forskael's - do .. ................... Crested .. do .. China........ Chinese.. do ..

FAMIL 2,-With the valves nearly equal.

Orientalis ...... Indian Seas ......... Indian .... do .. Folium.......... Amboyna, West Indies

Mediterranean........ Foliated .. do ..

Plicata....... W.Indies, Mediterranean,

Spain .............. Plaited.... do ..

Orbicularis ..... Indian Ocean ......... Orbicular . do .. Arborea ....... Atlantic \& Indian Seas.. Tree..... do .. Senegaleusis .... Senegal............. Senegal .. do..

Famux S.---With the valves strongly plaited longitudinally.

Crista-galli ..... Indian Ocean, China.... Cock's comb do .. Hyotis ......................... Horned.... do .. Frons......... West Indies .......... Crested.... do ..

Division V.-With the hinge composed of transverse furrows in a straight line.

*Crenatula..... Red Sea............ Crenated .. do.. Semiaurita ..... Méditerranean ....... Half-eared do .. Perna ........ East \&West Indies, China Oblong ... do .. Isognomon ..... Amboyna ........... Long-hinged do.. Ephippium..... Tranquebar, Africa.... Saddle .... do .. Alata ........ West Indies .......... Winged ... do .. Picta .... ..... Red Sea ............ Painted.... do .. Legumen ...... Nicobar Isles ........ Pod-shaped do.. 
Drvision VI. - Valves slightly striated, lower valve turning up at its sides, and the cartilage of the hinge placed in a deep narrow groove.

Scientific Name. Locality.

Common Name.

Spondyloidea.... Indian Ocean ........ Spondyloid O...

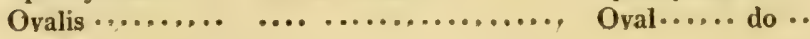

Division VII. -Valves coarse and rugged, and not comprehended in the former divisions.

The O. edulis (common Oyster) is too well known for its nutritious and palatable qualities to require description; the old shells are often covered with various adhesions, such as Anomiæ, Serpulæ, Lepades, Sertulariæ, and other marine productions. The interior has generally a pearly appearance, and some specimens have been found containing pearls.

They are to be met with in most seas, occasionally in clusters, affixed to rocks or other substances. In some places they are considered so profitable a branch of commerce, that they are frequently formed into large layers or beds, many miles in extent, in which, by proper attention to their increase and growth, their multiplication becomes immense.

The Roman historians assert that the tables of the great were supplied with this delicacy from the coasts of Britain.

Scientific Name.

Denticulata......

Edulis ...........
Locality.

Cape of Good Hope .... Toothed Oyster.. British and other Seas... Eatable... do . 


\section{ANOMiA._Anomia on Antique Lamp.}

\section{DESCRIPTION OF PLATE $\boldsymbol{x V}$.}

Drv. I.-Fig. 6. A. ephippium.

Fig. 5. Variety of do.

Fig. 7. Plug of fig. 6. by which

the shell attaches itself to

other substances.
Drv. I1.-Fig. 2. A. caput-serpentis. Fig. 3. A. psittacea.

Fig. 4. A. rosea.

Drv. III.-Fig. 1. A. placenta.

Shell bivalve, inequivalve, one of the valves flatish, the other gibbous at the base, with a produced beak, generally curved over the hinge; one of the valves often perforated near the base: hinge with a linear, prominent cicatrix, and a latcral tooth placed within, but in the flat valve, and on the extremety of the margin: two bony rays for the base of the animal.

OF this singular genus of Bivalves, there are thirty species, many of which are extremely rare and valuabie.

The Anomix differ materially in form: some resemble the shape of an Oyster, as the A. cepa, A. ephippium, \&c. all of which have the lower valve flat and perforated; others, again, are imperforated, and nearly orbicular, as the A. placenta, \&c.; and some are oblong, as the A. bifida, \&c. Many species, particularly the A. caput-serpentis, when seen in profile, resemble the form of an antique lamp; and a few, as the A. psittacea, \&c. are very similar to the hooked or curved beak of a parrot.

The shells are usually inequivalve, one of them often flattish, and the other gibbous at the base, terminating in a produced beak, which curves upwards over the 
hinge. There is frequently a small perforation in the beak, near the base, through which a strong ligament is protruded, whereby the animal affixes itself to different marine substances, as fuci, crabs, spines of echini, and especially to the stars of the Madrepora Prolifera.

The hinge of the Anomia admits of considerable variation; but its most leading character is that of being furnished with a linear prominent cicatrix, and a lateral tooth placed within. On the margin of the flattest valve in many species, are placed two cartilaginous substances, which serve as a base for the animal; but some have only one of these in each valve. The margin is fiequently crenated, notched, or toothed, but in many it is perfectly smooth.

The interior of the shells of this genus has often a silvery appearance; the prevailing color of the exterior is a dirty yellow, or dusky white, and some are bright yellow, as the A. electrica, \&c. The A. cepa, and the A. sella, have a bronze-like appearance; and the A. capensis and A. sanguinea exhibit a beautiful pink or red coloring. The A. psittacea, and other similar species, have a dingy or olive black color, and a few are found of a shining, jet black.

Some of the Anomiae are almost smooth; others, on the contrary, are marked with ribs and strix, which in the A. muricata are covered with scales, and hollow spines of considerable length.

The shells are generally thin and delicate, and usually semitransparent. The A.placenta, when in young state, becomes so transparent by the process of polishing, 
that it is frequently used by the ingenious Chinese, as a substitute for window-glass.

The A. sanguinea, A. rosea, A. psittacea, and most of the second division are extremely rare.

The European, Indian, American, and African oceans supply many species of the Anomia, as also do the Mediterranean and Northern seas.

This genus has probably been termed 'Avoria (Anomia), from its not possessing any determinate character.

Division I.-Lower valve flat and perforated.

Scientific Name.

Craniolaris.

Turbinata

Ephippium

Cepa.

E

Electrica....... France, Mediterranean, Africa ..............

Punctata ...... Ferroe Islands ........

Aculeata....... Norway, Britain .......

Muricata .... . Guinea .............

Undulata...... Britain, Norway, Mediterranean ............ Striated .. do ..

Patelliformis..... Norway............. Limpet shap'd do Squama ...... Ditto .............. Scaly .... do .. Bifida ......... Mauritius, Mediterranean Bifid..... do .. Cylindrica ..... Norway, Britain ..... Cylindrical do ..

Drvision II.-Having the umbo perforated, and yenerally a cartilaginous substance in the interior of the shell.

Scobinata ..... Mediterranean ........ Rough .... do .. Aurita....................... Eared ... . do .. Retusa ........ Norway ........... Blunt.... do .. Truncata...... Ditto, Mediterranean.... Truncated do.. Capensis...... Cape of Good Hope ... Cape..... do .. F 2 
Decollata...... Mediterranean ........ Semicircular A.

Pubescens ..... Norway ............ Downy ... do ..

Sanguinea ..... Indian Seas ......... Scarlet rayed do.. Caput-serpentis . Norway ............ Suake's head do..

Terebratula .... Ditto, Mediterranean... Lamp. ... do ..

Cranium ....... Norway ............. Brittle ... do ..

Cruenta ....... New Zealand......... Blood red.. do ..

Dorsata....... Magellan ........... Keeled .... do ..

Psittacea....... Newfoundland, Ind. Seas Parrot beak do..

* Rosea....... South Seas .......... Pink..... do ..

Division IIl.-Imperforated, and having a truncated triangulav. hinge.

Placenta...... Tranquebar, China..... Cake..... do ..

Sella ......... Ditto, Amboyna ....... Saddle .... do .. 


\section{MYTILUS. _MúscLE.}

\section{DESCRIPTION OF PLATE XVI.}

Drv, I. -Fig. 2. M. pellucidus. Drv. VI. Fam.2. Fig. 6. M. hiruodo. Drv. II.-Fig. 5. M1. discors.

Drv, VIII. Fig. 3. M. lingua.

Div. III.-Fig, 1. M. lithophagus.

Fig. 4. Interior of Fig. 3.

Shell bivalve, rough, nsually affixed by a byssus or beard of silky fivwents; hinge mostly without teeth, with gonerally a subulate excavated longitudinal line.

OF the gemus Mytilus forty-six species are enumerated; though some of these are rather indistinct in character, yet the greatest proportion of them bear a near alliance to the general form and habits of the common or eatable Muscle.

The hinge of the Mytilus is usually without teeth, having generally in their place a subulate excavated line. Some, however, have small denticulations, with alternate grooves, varying in different species from ten to fifty; in the M. niger, which has the greatest number, they amount to nearly one hundred.

A particular class posscsses the faculty of penetrating coral and calcareous rocks; from which, like the Pholas, the shell cannot be extracted withouit breaking the substance in which it is imbedled. Of this description are the M. lithophagus, M. rugosa, \&c. the latter of which is sometimes found in lakes, as wcll as the sea.

There are some species which are frequently mistaken as belonging to the genus Mya; such as the M. latus, M. discors, and M. amgulatus; but, hy a careful 
inspection of the hinge, the error will soon be discovered.

Muscles differ greatly in external appearance, some being perfectly smooth, and beautifully marbled and variegated with delicate colors; others elegantly radiated with purple and white; and a third class being of one color only, as black, blue, green, yellow, or brown, and coarsely ribbed and grained with minute tubercles. In the greater part the coloring is confined to the epidermis; when this is removed, and the shell polished, so different a surface is presented, that an adept would be puzzled to decide to what species it should be referred. In some specimens the epiderunis is shaggy or bearded.

Many exhibit internally a pearly appearance, and some, when uncoated and polished, display considerable brilliancy. The M.margaritiferus is celebrated for its iridescent colors, and is, moreover, valued for the beautiful and costly pearls it produces. The young shells of this species are sometimes so different to the adults in appearance, that they cau scarcely be recognised as - being the same.

The M. edulis is found in immense beds or layers, and invariably affixes itself to other bodies by means of its silky byssus.

The M. cygneus and M. anatinus, (both fresh-water species), frequently become the prey of birds: when the shell is too hard to be penetrated by their beaks, they mount with it to a considerable height, and by letting it fall, are enabled to pick out the fish from the broken shell. 
The M. discrepans, M. lingua, and M. arborescens may be particularised as rare species.

The Indian, Atlantic, American, and Northern oceans produce many species; some are also found in New Zealand, and in the Red, Mediterranean, and Russian seas. Mvridos (Mytilus) is the name given to this genus by the antient naturalists.

Division I. -Shell oblong, umbones or apices terminal and pointed, slightly angulated at one side, and rounded at the lower margin.

Scientific Name.

Edulis

Pellucidus .......

Vulgaris ........

Bilocularis .......

Ungulatus $\ldots . .$. .

Exustus .........

Striatulus ........

Niger........ .

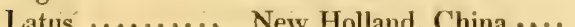

Perna ......... Straits of Magellan......

Smaragdinus ..... Tranquebar, Guinea.....

Confusus........................

Bidens......... America, South Seas, Mediterranean, Magellan Double tooth'd do

Puniceus ..... Goree............... Ventricose do..

Demissus .... .. Carolina, North America Silvery.... do ..

Ruber......... Southern Ocean ....... Red ..... do ..

Division II.-Transversely ovate, with longitudinal ribs on each side, and plain or striated in the middle.

Discrepans ..... Baltic, Britain......... Compartment do Discors ........ Norway, Britain ....... Discordant do .. Impactus....... New Zealand ......... Woolcoateci do .. 
Division III.-Found burrowed in rocks, corals, \&c.

Scientific Name.

Lithophagus .... Indian, European, \& Mediterranean Seas......

Aristatus........ Senegal $\ldots . . . . . . .$.
Ambiguus ..... Weymouth, Coast of Devonshire ........... Ambiguous do..

Rugosus ...... Britain, Norway ...... Rugged .. do .. Coralliophagu .. East \& West Indies .... Coral-piercer do Præcisus ....... Britain .............. 'I'runcated. do .. Fuscus........ East Indies .......... Brown .... do .. Plicatus ...... Nicobar Isles ........ Plaited .... do . Niveus........ Ditto.............. Snow white do .. Arborescens .... China, St. Domingo .... Dendritical do ..

Drvision IV.-Shell oblong, gibbous, with the posterior side dilated and elevated above the hinge, apex rounded.

Modiolus ....... Britain, W. Indies, Africa Great .... do ..

Drvision V.-Only found in fresh water.

Cygneus...... Europe............ Swan .... do ..

Fluviatilis ...... North America ... ... River .... do ..

Stagnalis ...... Lake of Schrvansee..... Stagnant .. do ..

Anatinus....... Europe............ Duck .... do ..

Fucatus ....... Wiltshire, North America Avon .... do ..

Dubius ........ Senegal, China ........ Doubtful .. do ..

*Americanus.... North America........ American.. do .. 
Division VI.-Eared.

FamLY 1.-Valves rather compressed.

Scientific Name.

Locality.

Common Name.

Margaritiferus... Amboyna, China....... Pearl Muscle ..

Radiatus ........ Tranquebar.......... Rayed .... do ..

Unguis ....... Mediterrancan....... Nail ..... do..

Family 2.-With one valve more convex than the other.

Hirundo ....... West Indies, Ceylon, Mau-

ritius, Britain ........ Stvallow ... do..

Morio ........ Red Sea............ Mulberry .. do..

Ala-corvi....... South Seas.......... Crow's wing do..

Drvision VII.-Shell suborbicular, longitudinally striated, and margin crenulated.

Faba ........ Greenland .......... Bean .... do ..

Division VIII.-Somewhat tongue-shaped, apices acute.

Lingua ....... Amboyna.......... Tongue ... do ..

Camellii ...... Japan ............. Camellius' . do .. 

PINNA._Fin Shell, Nacre, or Sea-Wing. DEsCRiption of PLATE XVII.

Fig. 2. P. cancellata.

Shell bivalve, fragile, upright, gaping at one end, and furnished with a byssus; linge without teeth, the valves united into one.

THE number of species contained in this genus is twenty-one; they are in general very brittle and fragile, and some are so similar to each other that they are with difficulty distinguished.

The usual form of the Pinnæe resembles that of the larger species of Muscles, being long and tapering, narrow at the beaks, and gradually expanding to a considerable breadth towards the opposite extremity: in a few instances the form is rather compressed, and sometimes subangular. They universally gape at one end.

The hinge is invariably without teeth, the valves, nevertheless, adhere so closely in the region of the beaks, that they appear as if united together.

The Pinnæe are usually covered with longitudinal ribs, and elevated transverse strix, often terminating in imbricated scales, and prominent tubular spines, as may be particularly observed in the P.rudis and P.muricata, but in the younger shells of these two species, the spines appear only as minute prickles; in other specimens, as the P. saccata, \&c. the ribs are less articulated, and perfectly free from scales or spines.

Some of the young shells of this genus are less 
than an inch in length, but the adults often exceed three feet.

The Pinna admit of some variation in color, though they usually have a horn-like appearance, which is often shaded with a steel-blue or copper-colored gloss.

This genus produces, in large quantities, a very fine sort of byssus or beard, which the Italians frequently fabricate into various articles of wearing apparel, vieing in appearance with the finest silk.

The Pimme are usually found in smooth water and bays; in some places they are esteemed excellent and luxurious food. The Mediterranean produces a great number; they are also to be found in the Indian, American, Atlantic, and European oceans, as well as in the Adriatic and Red Seas.

Пivva (Pinna), like the preceding genus, admits only of conjectural definition.

Drvision I.-Shells longitudinally ribbed.

Scientific Name.

Rudis

Pectinata .......

Inflata........

Carnea..........

Rigida

Nobilis ..........

Adusta ..........

Vexillum ......

Squamosa $\ldots . . .$. .

Vitrea ..........

Papyracea
Locality.

Mediterranean, Southern and Asiatic Seas .... Rough Pinna ..

Coromandel, Britain .... Spiny ribb'd do ..

Nicobar Isles.......... Inflated.... do ..

Dorsetshire, West Indies Flesh colored do

Curacoa............ Rigid .... do...

Mediterranean, Adriatic. Great .... do ..

E. Indies, Mediterranean Prickly.... do ..

South Seas, Manilla .... Pear shap'd do..

East Indies ............ Banner ... do ..

Mediterranean ........ Scaly ... . do ..

East Indies .......... Brittle ... do ..

Ditto ............... Paper ... do .. 
BIVALVES — PINNA.

Locality.

Indian Ocean ......... Satchel Pinna ..

Saccata.......

- Cancellata ....
Ceylon ............... Cancellated do ..

Drvision II.-Shell nearly smooth and plain.

Nigra ....... South Seas, Amboyna ... Black .... do ..

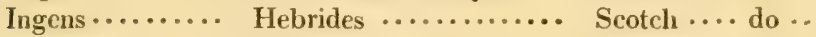

Rotundata ..... Mediterranean ........ Giant .... do ..

Bicolor ........ Red Sea ............ Two color'd do ..

Incurva....... Amboyna ............ Incurved .. do ..

Digitiformis .... Indian Ocean ......... Finger shap'd do

Lobata ....... Ditto............. Lobed .... do .. 



\title{
ORDER III.
}

\section{ชnivalbes.}

\begin{abstract}
I. SHELl OF ONE PART ONLY, AND HAVING A REGULAR SPIRE.
\end{abstract}

\section{ARgONAUTA. - Paper SaIlor.}

\section{DESCRIPTION OF PLATE XVIII.}

Drv. I.-Fam. 1. Fig. 1. A. argo. Fam. 1. Fig. 2. A. tuberculata.

Shell univalve, spiral, involute, membranaceous, one-celled.

THE shells of this genus are remarkable for their excessive thinness and brittleness, and are perhaps surpassed by none in the delicacy and elegance of their structure. The form resembles that of a scroll, with a very large aperture. The surface is ornamented with numerous canaliculated grooves, proceeding from the summit to the outer margin, which is in general bicarinated; but there is one species, the $A$. vitrea, in which the margin is single, and the summit exteriorly curved.

The species of the first division have the keel toothed, which is not the case with those of the second, and the distinction of the third division is, that the umbilicus is perforated. 
The color of the shells is mostly blueish, or dingy white, but the keel is often tinged with a brownish hue.

The size of the Argonautæe differs greatly : the A.argo often attains twelve inches in width; and the A. cornu and $\mathbf{A}$. arctica seldom exceed four lines in diameter.

The A. vitrea is the most rare, and one of the most beautiful species of the genus.

The Mediterranean and Indian seas produce some varieties; others are from the Cape of Good Hope, and some inhabit the Atlantic, Northern, and Greenland seas.

Argonauta is derived from 'A to the companions of Jason in his expedition to recover the golden fleece.

\section{Division I.-Keel toothed.}

Famix 1.-Summit interiorly curved.

Scientific Name.

Argo Tuberculata .... South Seas, Brazils..... Tuberculated do Hians ........ China, Red Sea ...... Gaping ... do .. Gondola .. .... Mozambique, Mauritius.. Boat..... do .. Haustrum ... . East Indies .......... Bucket... do ..

Famix 2.-Summit exteriorly curved.

Division II.-Keel not toothed.

Cymbium...... Mediterranean ........ Minute.... do... Cornu ......... Cape of Good Hope .... Horn shap'd do ..

Drvision III.-Umbilicus perforated.

Arctica ....... Greenland .......... Aretic .... do .. 


\section{NAUTiluS._Pearly Sailor.}

\section{DESCRIPTION OF PLATE XIX.}

Drv. I.-Fig. 1. N. scrobiculatus Dir.I.-Fig.2. N. pompilius.

Drv. II.-Fig. 3. N. spirula.

Shell enivalve, divided into several chambers, communicating with each other by an aperture.

THE species of the Nautilus strongly resemble each other in structure, and have usually a dingy white color, with yellow markings. The most striking character of the genus is, that the whorls are divided into separate compartments or chambers, which are connected by a slender syphon, rumning spirally through the shell. The syphon is sometimes central and sometimes contlguous to the surface.

The general form of the Nautilus is spiral or scrolllike, which is particularly exemplified in the shells of the first and second division: but in the third, the species are conical or dentiform, and bear some resemblance to the Dentalia. The whorls are contiguous in the species of the first division, and detached or separated in those of the second and third.

The N. pompilius, when bisected, displays the pearly concamerations for which the genus is celebrated. Fine specimens of this species are often converted by the inhabitants of the East into drinking cups, on the surface of which they engrave various devices and ornaments; they also frequently remove the outer coating entirely, by which the beautiful pearly appearance of the shell becomes visible. 
The Nantili differ exceedingly in size; some are so small that they can only be defined by the microscope, while others are nearly a foot in diameter.

The N. scrobiculatus is the most rare species of this genus.

Some species of the Nautilus are found adhering to coral rocks, particularly the N. siphunculus, which is often brought from the coral reefs on the Sicilian shores. The American and Indian Oceans, as well as the Mediterranean, Adriatic, and Red Seas, produce species of Nautili; but the greater number are found on the European and British coasts. The species from the last mentioned locality are minute.

This and the preceding genus, from a similarity in form, were originally included under the same generic name Naviìos, (sailor), so called by the early naturalists, from the nautical skill which the animal of the Argonauta was supposed to exert in directing its fragile bark. The great difference in internal structure induced subsequent conchologists to separate the genera.

In the following enumeration of the species of the genus, we have omitted the names of those which we have not found figured in any author. They are, with few exceptions, microscopic shells.

Division I.-Spiral, with contiguous whorls.

Scientific Name.

Locality.

Common Name.

Pompilius...... Africa, Amboyna, China, India ............... Gt. chambered N.

Scrobiculatus.... New Guinea......... Sunken spiredo..

Lacustris...... Kent, Denmark ...... Lake..... do .. 
Minute or microscopic Shells.

Scientific Name.

Calcar ...........

Rotatus ........

Lavigatulus ....

Depressulus .....

Crispus .........

Beccarii ....... Britain, S. Seas, Adriatic

Balthicus ...... Baltic . ............

Crassulus ....... Reculver, Kent ........

Umbilicatulus ... Kent, Devonshire......

Lobatulus ...... Britain, Norway ......

Rugosus ....... Southern Ocean .......

Umbilicatus .... Croatia ..............

\section{Common Name.} Spur Nautilus .. Wheel .... do .. Smooth.... do... Compressed do... Keel-edged do :. Beccaria's . do .. Baltic .... do .. Strong .... do .. Umbilicated do .. Lobed .... do .. Rugged ... do .. Oblique jointed do

Division II.-Spiral, with detached whorls.

Spirula...... E. \& W. Indies, America Ram's horn do ..

Minute Shells.

Spengleri ....... India ............. Spengler's . do ..

Unguiculatus.... Ditto ............ Nail-shap'd do ..

Drvision 1Il. Elongated and almost straight.

Minute.

Semilituus ..... Kent, Shores of Liburni - Halfcrozier do ..

Lituus........ Red Sea ........... Crozier ... do ..

Carinatulus ..... Kent ............... Keeled ... do ..

Obliquus ...... Britain, Mediterranean - Obliquely striated

Raphanistrum ... Mediterranean ........ Twelve striated

Raphanus ..... Adriatic, Mediterrancan. Seventeen striated G 2 
Scientific Name.

Costatus

Granum

Radicula

Spinulosus

Sub-arcuatus

Bicarinatus

Fascia

Inæqualis

Siphunculus

Legumen

Linearis

Rectus
Locality.

Kent ................. Ribbed Nautilus

Mediterranean......... Eight striated do

Kent, Adriatic ........ Bulbous jointed do

Britain .............. Spinous jointed .

Sandwich ............ Sub-arcuated do .

Ditto ................ Bicarinated do ..

Adriatic .............. Banded ... do ..

Red Sea.............. Unequal .. do ..

Sicily .............. Piped ..... do ..

Britain, Adriatic....... Pod ..... do ..

Dunbar............... Linear .... do ..

Sandwich ............ Straight $\therefore$ do $\cdots$ 


\section{CONUS. - CoNE.}

\section{DESCRIPTION OF PLATE $\mathbf{X}$.}

Drv. I. Fam. 1. Fig. 1. C. imperialis. Div. II. Fam. 1. Fig. 6. C. ebræus. Fam. 2. Fig. 2. C. monile. Drv. III. Fig. 4. C. striatus. Fam. 2. Fig. 3. C. generalis. Fig. 7. C. terebellum. Div. II. Fam. 1. Fig. 5. C. taniatus. Drv. IV. Fig. 8. C. tulipa

Shell univalve, convolute, turbinate; aperture effuse, longitudinal, linear, without teeth, entire at the base; pillar smooth.

THERE is, perhaps, no other genus which holds so important a station in collections as the Cones, a disinction to which it is eminently entitled, from the matchless beauty and endless variety of the species.

The numerous species of the Cones are so similar in form, that they have been arranged only into four divisions. Those which have a subtruncated base, as the C. marmoreus and C. imperialis, constitute the first division. The $\mathrm{C}$. betulinus may be instanced as an example of the shells of the second division, which are pyriform and rounded at the base, and have a thick structure. The third division comprises those species which are elongated, and have an acute and prominent spire, as the $\mathrm{C}$. generalis, \&c. The shells of the fourth division are easily distinguished by their ventricose shape and wide aperture.

Beneath the epidermis the Cones have in general a smooth surface, and in most instances a high natural polish; there are, however, some species, as the C.gra- 
nulatus, \&c. which are covered with granulated transverse striæ, and even globular tubercles.

The colors and markings of the Cones are extremely beautiful, and much diversified: in some species they are elegantly disposed in dots, stripes, bands, and reticulations; and in others, delicately blended in cloudings, veins, and marbling.

The most beautiful and rare species of this genus are the C. gloria-maris, C. cedo-nulli, C. thomæ, the varieties of $\mathbf{C}$. ammiralis, $C$. aurisiacus and others, which vary in value from five to twenty guineas.

The Conus derives its name from the resemblance which its species bear to the form of a Cone (Kw̃vos)

The greater number of species come from the Indian Ocean; some are found on the shores of Africa and America, and others in the South Seas.

\section{Drvision I.-Spire subtruncated.}

FAMILX 1.-Spire coronated.

\begin{tabular}{|c|c|c|}
\hline Scientific Name. & Locality: & Common Name. \\
\hline Marmoreus ..... & $\begin{array}{l}\text { East and West Indies, Asi- } \\
\text { atic Ocean .......... }\end{array}$ & Marbled Cone . \\
\hline cturnus ...... & Amboyna, Moluccas.... & Night ..... do . \\
\hline Nicobaricus ..... & East Indian Seas ....... & Nicobar... do .. \\
\hline Arachnoideus ... & Coromandel, Tranquebar & Spider-web do. \\
\hline Conatus.......... & Asiatic Ocean .......... & Zoned .... do .. \\
\hline Imperialis ...... & $\begin{array}{c}\text { Amboyna, So. Seas, Mau- } \\
\text { ritius ................ }\end{array}$ & Imperial.. do .. \\
\hline Fuscatus........ & $\begin{array}{c}\text { South Seas, Mauritius, } \\
\text { Tranquebar.......... }\end{array}$ & Clouded - do \\
\hline
\end{tabular}


Faurcy 2.-Spire plain or channelled.

Scientific Name.

Literatus .......

Eburneus .......

'Tessellatus .......

Generalis......

Monile .........

Canaliculatus ...

Radiatus........

Virgo.......

Capitaneus......

Chemnitzii .....

Mustelinus ......

Leopardus ......

Hyæna .........

Miles ..........

Centurio .......

Pusiformis ......

Spurius .........

Leoninus .......

Characteristicus .

Crerulescens.....

* Zebra .........
Locality.

Amboyna, S. Seas, Africa

East Indian Ocean ......

Batavia, Africa, Mauritius Amboyna, Mauritius, C.

of Good Hope ........

Nicobar Isles .........

Ceylon, Nicobar Isles ...

West Indies ...........

Africa, Amboyna, Mau-

ritius........ Virgin.. do.

Amboyna, Mauritius, East Indies .............

Ceylon ..............

Batavia, Philippines ....

E. \& W. Indies, Sumatra

New Zealand, Africa ...

Amboyna, Mauritius ....

St. Domingo, Martinico.

California.............

East and West Indies....

Amboyna, West Indies,

Mexico ............

St. Bartholomew .......

St. Thomas ...........

New Guinea ..........
Comimon Name.

Lettered Cone ..

Square spotted do

Mosaic ... do ..

General ... do ..

Necklace.. do ..

Grooved .. do ..

Radiated .. do ..

Captain .. do ..

Chemnitz's do..

Weasel ... do ..

Leopard .. do ..

Hyena .... do ..

Soldier ... do ..

Centurion : do ..

Fusifurm .. do ..

Spurious .. do ..

Lion ...... do ..

Arabic ... do ...

Blue ...... do..

Zebra... .. do.

Drvision II.-Pyriform, rounded at the base.

Fanily 1.-Spive coronated.

Cedo-nulli .... Caraccas, South America Matchless - do .. Aurantius ..... Philippines .......... Orange... do .. Leucosticus .... West Indies, Mauritius . Veined ... do .. Tæniatus ....... Africa, China, N. America American flag do Musicus ...... China ............ Music .... do . 
UNIVALVES - CONUS.

Scientific Name.

Miliaris

Luzonicus ......

Lividus ........

Mus

Distans

Caledonicus .....

Costatus ........

Ebræus

Princeps ........

Arenatus

Pulicarius.....

Obesus .......

Piperatus .......

Varius.........

Coronatus

Barbadensis ....

Roseus .........

Coccineus ......

Citrinus

Sponsalis........

Puncturatus.....

Ceylonensis .....

Exiguus ........

Pusillus ........

Lamellosus......

Sulcatus ........
Locality.

China

Philippines ...........

East \& West Indies, Cape of Good Hope .......

American Ocean, West Indies ............

South Seas, Nicobar....

New Caledonia ........

South Seas, China ......

East Indies, Amboyna,

China ............

Asiatic Ocean .........

Batavia, Mauritius, Cape of Good Hope........ South Seas, Moluccas .. Madagascar, China ..... Ind. Seas, African Ocean Mauritius, West Indies .. East Indian Seas ........ Barbadoes, West Indies . Antilles ............. St. Domingo, Martinico.. Curaçoa, Straits of Magellan .............

S. Seas, Isle of St. George Botany Bay ........... Ceylon

Asiatic Seas ...........

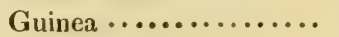

Ceylon ................ West Indian Seas ...... Grooved .. do ..
Common Name.

Millet Cone ... Spotted velvet do Livid .... do .. Mouse ... do .. Wide lined do.. Caledonian do .. Ribbed.... do ..

Hebrew .. do .. Persian robe do ..

Sandy .... do .. Flea spot .. do .. Fat ....... do .. Punctured - do .. Various ... do .. Coronated - do .. Barbadoes - do . Rose-color'd do .. Scarlet.... do .. Citron color do .. Pink spotted do.. Groove punctured Ceylonese - do .. Narrow ... do .. Dwarf .... do .. Plaited spire do ..

\section{FAMILY 2.-Spire plain or channelled}

Janus ........ East Indian Ocean ..... Janus .... do ..

Guinaicus ..... Guinea ............. Guinea.... do ..

Fulmineus ...... Africa, New Zealand.... Lightning - do ..

Lorenzianus .... E. Indian Seas, Africa .. Lorenza's - do .. 
UNIVALVES_CONUS.

Scientific Name.

Amadis ........

Acuminatus ....

Thomre .......

Ammiralis ......

Archithalassus ..

Vitulinus ........

Planorbis ........

Senator ........

Catus ..........

Nobilis .........

Siamensis .....

Genuanus .......

Papilionaceus....

Fluctifer

Glaucus ........

Suratensis

Monachus ......

Ranunculus .....

Anemone .......

Achatinus ......

Rusticus ........

Nisus........

Coffeac.

Vittatus.........

Classiarius ......

Mercator........

Betulinus

Figulinu

* Inornatus......

Quercinus ......

Lineatus ........

Eques.........

Ermineus .

\section{Locality.}

Bantam, China, Ceylon . Amiboyna, Red Sea, Moluccas ...............

Isle of Oma, Asiatic Ocean Amboyna, Ceylon, Ceram Indian Ocean, Amboyna. West Indies, Mauritius..

Guinea ...............

Guinea ...............

St. Domingo, C. G. Hope Amboyna, China, Moluccas...............

China, Siam ..........

Batavia, Senegal, E.Indies

S. Seas, Mauritius, West Indies . ..........

Java, Mozambique...... Amboyna, Moluccas .... East Indian Ocean ..... Mediterranean, Mauritius,

China ............ American Ocean ........ New Holland ......... Batavia, Mauritius ...... Amboyna ............. East Indian Ocean ...... American Seas......... Asiatic Ocean ........ . Ditto ................. Senegal, Mauritius, Cape of Good Hope ........ East Indies, Amboyna, Mauritius ......... Isle of France, NicobarIsles Sumatra............. South Seas, Cape of Good Hope, Madagascar ... Mauritius, Philippines .. New Zealand .......... E. Indies, Mauritius, China
Common Names

Amadis Cone ..

Sharp pointed do St. Oma's - do .. Admiral .. do .. Granulated do.. Spotted.... do .. Depressedspire do Senator... do .. Cat ...... do..

Noble .... do .. Siamese ... do .. Gartered .. do ..

Butterfly's wing

Prometheus do.. Brownish - do .. Surat .... do ..

Monk .. . do .. Ranunculus do .. Anemone.. do .. Tulip .... do .. Rustic .... do .. Brown throated do Coffee .... do .. Ribbon.... do .. Sailor .... do ..

Network .. do ..

Birch bark do .. Brown banded do Naked ... do ..

Oak ..... do.. Lineated .. do .. Equestrian do.. Ermine ... do .. 
UNIVALVES - CONUS.

Scientific Name.

Vexillum .....

Testudinarius....

Venulatus ......

Namocanus......

Stercus-muscarum

Cancellatus......

Portoricanus ....

Tinianus........

Taitensis ........

Scabriusculus ...

Rattus..........

Jamaicensis .....

Mediterraneus ..

Puncticulatus....

Mauritianus .....

Verrucosus .....

Columba .......

Madurensis......

Jaspideus .......

Japonicus ......

Mindanus ......

Festivus ........

* Reticulatus....

* Ferruginosus .
Locality.

Batavia, Malabar .......

Surinam,W.Indies, Guinea Manilla, American Seas..

Isle of Namoca, S. Seas .

Amboyna, Cape of Good

Hope, Ceylon .........

South Seas ...........

Porto Rico, American Seas

Isle of Tinian, South Seas

Otaheite..............

Guinea, Sierra Leone ...

Coast of America ......

Jamaica ............

Algiers, Mediterranean..

St. Domingo, Martinico .

Coast of Africa .......

Africa, Cape of G. Hope

Mauritius ............

Asiatic Ocean ..........

St. Domingo, Martinico .

Japan .... ...........

Philippine Isles ........

Molucca Isles ..........

South Seas ...........

Ditto.................
Common Nane.

Flag Cone ...

Turtle .... do ..

Veined.... do ..

Ashwood .. do ..

Fly-spotted do ..

Cancellated do ..

Porto Rico do ..

Red color'd do ..

Blackish violet do

Scabrous - do ..

Rat ..... do ..

Three banded do

Olive clouded do

Red dotted do ..

Mauritian - do ..

Warted ... do ..

Dove ..... do ..

Green cross do :.

Jasper .... do ..

Orange mottled .

White mottled do

Festive ... do ..

Netted .... do ..

Iron color'd do ..

\section{Division III.-Elongated and rounded at the base.}

Clavus.......... East Indies, Guinea .... Yellow veined do

* Gradatus ..... California ........... Stepped .. do ..

Aureus ....... China ............ Golden.... do ..

Circumcisus..... East Indian Ocean ...... Truncated . do ..

Terebellum .... Mauritius, Madagascar.. Chocolate.. do ..

Australis....... New South Wales, China Southern .. do ..

Lrvis ........ Africa............. Smooth ... do ..

Ochroleucus .... American Seas ........ Yellowish - do ..

Strigatus...... East Indian Seas....... Pale violet.. do ..

Mitratus...... Ditto............. Mitre.... do .. 
UNIVALVES _ CONUS.

Scientific Name.

Glans

Tenellus.......

Nussatella ......

Granulatus......

Fusus ..........

Aurisiacus ......

Terebra .......

Raphanus .......

Adansoni

Augur..........

Magus..........

Striatus ...... South Seas, Mauritius,

Gubernator .....

Gloria-maris ...

Pyramidalis .....

Textile ........

Abbas..........

Archiepiscopus ..

Canonicus ......

Episcopus …...

Pralatus........

Pannaceus ......

Rubiginosus ....

Omaria ........

Aulicus........

Elongatus
East \& .Vest Indies ..

Locality.

Mauritius, Africa, Mo-

luccas ..............

Moluccas .............

Nussatella ............

Africa, America, Brazils.

West Indies .......... .

Amboyna, Ceram ......

Batavia, Mauritius ......

Asiatic Ocean ..........

Senegal .............

Ceylon, Amboyna......

Mauritius, Amboyna ....

Asiatic Ocean ..........

Japan ...............

Torrid Zone ............

South Seas, China, Africa

Mauritius ............

East Indian Seas .......

Ditto .................

Ditto...........

Ditto ..................

Amboyna, China ......

Amboyna, Philippines ..

New Guinea, Madagascar

Mauritius, Amboyna, Cey-

lon, China ..........

Guinea ..............

\section{Common Name.}

Acorn Cone ..

Delicate... do ..

Nussatella - do ..

Grained .. do ..

Spindle ... do ..

Orange.... do ..

Whimble.. do ..

Radish .... do ..

Adanson's - do ..

Augur .... do ..

Magician .. do ..

Striated .. do... Pilot .... do ..

Glory of the sea Pyramid .. do .. Embroidered do Abbot .... do .. Archibishop do .. Canonical - do .. Bishop .... do .. Prelate.... do .. Plumose .. do .. Orange brown do Pearlbrown Cone Brunette -. do .. Lengthened do ..

Division IV.-Ventricose with a wide aperture.

Spectrum ...... Amboyna, China, New

Guinea ............ Spectre $\cdots$ do ..

Informis ....... New Zealand, American

Ocean ............. Misshapen do . 
UNIVALVES — CONUS.

Scientific Name.

Locality.

Common Name.

Ventricosus

American Ocean, Medi-

terranean .......... Ventricose Cone

Bullatus ...... Moluccas, China...... Bubble ... do ..

Timorensis ...... East Indian Ocean ...... Timor .... do ..

Nimbosus ...... Ditto.............. Rainy .... do ..

Tulipa ......... E. \& W. Indies, Africa.. Tulip ... . do ..

Geographicus ... Amboyna .......... Geographic do... 


\section{CYPRÆA._CoWrY.}

\section{DESCRIPTION OF PLATE XXI.}

Div. I. -Fig. 2. C. exanthema. Drv. III.-Fig. 4. C. ziczac.

Fig. 3. Do. in a young state. Drr. IV.-Fig. 5. C. cribraria.

Drv. II.-Fig. 1. C. pantherina. Dr. VI.-Fam. 1. Fig. 6. C. nucleus.

Shell univalve, involute, subovate, smooth, obtuse at each end; aperture effuse at each end, linear, extending the whole length of the shell, and toothed on each side.

THIS genus possesses one grand mark of distinction, the shells having, when arrived at maturity, the two lips always crenated with strong articulated teeth. The species differ little in formation, but their colorings and markings are very dissimilar.

There are six divisions in the Cypræa: the first includes those in which the spire is not quite concealed, as in the $\mathrm{C}$. exanthema, $\mathrm{C}$. arabica, \&c. Those, on the contrary, which have no manifest spire, as the $\mathrm{C}$. caputserpentis, C. mauritiana, \&c. form the second division. The third is composed of the umbilicated or perforated varieties; such as the $\mathrm{C}$. ziczac, C. asellus, \&c. Those species which are marginated, as the $\mathbf{C}$. moneta, C. annulus, \&c. form the fourth class. The shells of the fifth division have their surfaces covered with ribs, wrinkles, or tuberculations; and the sixth consists of those which are beaked at the extremities.

The Cowries are in general smooth, glossy shells, of great brilliancy of color, and elegantly marked with dots, ziczac lines, undulations, stripes, \&c. The C.aurantium, 
C. mappa, C. arg'us, and the C. testudinaria, may be adduced as examples of the beauty and variety of coloring for which the genus is remarkable. The C.nucleus, C. cicercula, and C. staphylaea, are, however, exceptions, as they have but little coloring, and are besides extremely rough, owing to the small globular tuberculations or warts, with which their surfaces are covered.

One of the largest and most valuable Cowries is the C. aurantium, which is found, though very rarely, at the Friendly Isles. The most rare of the smaller species are the C.rubiginosa, C. pustulata, and C.aperta.

The greater number of the Cypræa are produced in the Indian Ocean; many, however, are found in the American, African, and Mediterranean seas; and some also in the South seas.

This genus has been named after the Cyprian God-

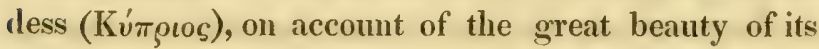
species.

Drvision I.-Spire not quite concealed.

Scientific Name.

Exanthema … American Ocean, West

Indies .............. False Argus ...

Mappa ........ Africa, Amboyna ..... Map Cowry ..

Arabica ... ... Amboyna, Madagascar .. Arabic . .. do ..

Histrio ........ South Seas, Indian Ocean Harlequin.. do ..

Argus ......... Amboyna, Guinea, West

Indies ........... Argus ..... do ..

Testudinaria .... Persian Gulf, Amboyna.. Tortoiseshell do..

Stercoraria..... Coast of Guinea ....... Livid ... do ..

Aurora................ South Seas ........ Orange ... do

Carneola....... Amboyna, East Indies .. Flesh color'd do .. 
UNIVALVES _ CYPR EA.

Scientific Name.

Talpa

Lurid.

Vanelli

Lota.

Guttata ........

Sanguinolenta .

Undata $\ldots . . .$. .

Teres

* Apería .......
Locality.

Asia, Madagascar .....

Mediterranean, Senegal,

Brazils ............ Lurid .... do ..

Barbadoes, Jamaica .... Saffiron throated .

Sicilian Seas .......... White .... do ..

.................. Dotted .... do ..

..................... Sanguine .. do

Mauritius............ Waved.... do ..

.................. Long ..... do ..

Wide-mouth'd do

Drvision II._Obtuse, spire quite concealed.

Achatina ... ... South Seas, New Holland Agate ... do .. Caput-serpentis.. Ditto, Mauritius, E. Indies Snake's head do.. Mauritiana ..... Persian Gulf, Mauritius.. Blackish brown do

Vitellus ....... Amboyna, South Seas .. Whitc spotted do Mus.......... Mediterranean, Africa... Mouse .... do .. Tigris ......... R. Sea, S. Seas, Amboyna Tiger .... do .. Pantherina..... Red Sea........... Panther .. do ..

Lynx ......... Mauritius, Madagascar .. Lynx .... do ..

Felina ........ Maldives ........... Feline .... do ..

Cinerea ....... Barbadoes, Jamaica .... Ash-color'd do ..

Isabella ... ... Amboyna, Mauritius, Madagascar............ Yellow ... do ..

Cylindrica ....................... Cylindric . do .. Indica ....... Eastern Ocean........ Green spotted do

\section{Division UII.-Umbilicated.}

\begin{tabular}{|c|c|}
\hline & \\
\hline $\begin{array}{l}\text { Onyx .......... } \\
\text { Subflava } \ldots \ldots \ldots\end{array}$ & Coast of Asia $\ldots \ldots \ldots \ldots$ \\
\hline landestina ..... & $\ldots \ldots \ldots \ldots \ldots \ldots \ldots$ \\
\hline
\end{tabular}


Scientific Name.

Succincta .......

Ziczac..........

Zonata.........

Hirundo

Ursellus ........

Lutea .........

Asellus

Errones ........

Pyrum..........

Punctata .......
Locality.

................... Banded Cowry .

East Indian Ocean ...... Ziczac .... do ..

Coast of Guinea ........ Zoned .... do ..

Maldives, Antilles ...... Swallow .. do ..

................... Brown spot do ..

...................... Yellow do..

Amboyna, Senegal, Mal-

dives . ............. Three banded do

East Indies ........... Olive mottled do

Sicily, Africa ......... Pear ..... do ..

.....................

Dotted .... do ..

\section{Division IV. - With the margin thickened.}

The C. moneta of this division is collected by the negro women of the Indian Islands, three days before and after full-moon, and transported into Bengal, Siam, and Africa; where it is used by the natives in commerce, as a substitute for money.

Scientific Name.

Moneta.........

Annulus .........

Caurica ........

Dracæna ........

Cruenta .......

Cribraria .......

Erosa $\ldots . . . . . .$.

Flaveola

Spurca $\ldots$

Stolida....... .

Tabescens .......

Helvola .........

Angustata ......
Locality.

Indian Islands

Amboyna, East Indies .

Madagascar, Amboyna .

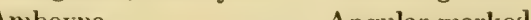

Ditto ................ Ferruginous do ..

China ............. Umbilicated do ..

Mauritiıs, Bengal ...... Bordered .. do ..

.................... Ochreous.. do ..

Mediterranean ....... Narrow margin'd

Eastern Occan......... Square spotted do

Amboyna, Madagascar.. Slender ... do ..

Ditto, Maldives ........ Star...... do ..

................... Narrow ... do .. 
Scientific Name.

Locality.

Common Name.

Ocellata...... Indian Ocean, China... Eyed Cowry ...

*Albuginosa.... California ........... Bird's eye - do ..

Poraria ........ Jamaica ............. White spot do..

Gangranosa .... China .............. Gangrene.. do ..

Fimbriata ...................... Fimbriated do ..

Tessellata...... ................. Mosaic .... do ..

Division V.-With the backs ribbed, wrinkled, or tuberculated.

Oniscus ....... Adriatic Sea ........ Woodlouse do..

Sulcata ....... Jamaica, Barbadoes .... Sulcated .. do ..

Europea ...... Britain, North of Europe European - do ..

Madagascariensis Madagascar ........... Madagascar do..

Pustulata ..... Acapulca, China ..... Pustulated. do ..

Division VI.-Beaked at the extremities.

Famuy 1.-Having raised dots on the back.

Nucleus ...... East Indian Ocean ..... Wriukled . do ..

Staphylea ..... Ditto ............... Groove back'd do

Cicercula...... Mediterranean, Amboyna,

China............ Vetch ... do ..

FamiLy 2.---With the back smooth.

Margarita ..... Amboyna ............ Pearl .... do ..

Globulus..... . Ditto, Asia ......... Globular .. do .. 



\section{BULLA. - Dipper or Bubble.}

\section{DESCRIPTION OF PLATE XXII.}

Drv. 1.-Fig. 3. B. verrucosa.

Div. II.--Fig. 1. B. volva.

Fig. 2. B. gibbosa.

Drv. VI.-Fig. 4. B. terebellum.
Drv. III.-Fam. 2. Fig. 5. B. amplustre.

Drv. IV.-Fig, \%. B. ficus.

Drv. V. -Fig. 6. B. virginea.

Shell univalve, convolute, unarmed with teeth; aperture a little straitened, oblong, longitudinal, very entire at the base; pillar. oblique, smooth.

THIS genus is so nearly allied in form to the preceding, that much caution is necessary in order to prevent confusion in its classification; so great indeed is the difficulty of distinguishing the young shells of the Bulla and Cypraea, that the two genera have been intermixed by some authors.

This difficulty may, however, in a great measure be removed, by an attention to one very striking character of the Bulla, that the pillar lip of the shell, in every state of its growth, is invariably free from the slightest denticulations; while, in the Cypraea, both the pillar and outer lips are crenated with strong articulated or prominent teeth. This distinction constitutes the character of the first of the divisions, into which the genus is separated. The other divisions are in general disting uished by the form, of which the Bulla presents a considerable variety. The second division comprehends the species which are elongated: in these the length is increased by two produced beaks, conspicuously observable in the B. volva. In the third di- 
vision the shells are less beaked, and more gibbous; the $\mathrm{C}$. naucum and $\mathrm{C}$. ampulla may be mentioned as illustrative examples: they are without teeth or spire, and the greater part umbilicated. The species of the fourth division are pyriform; of which the B. ficus and B. rapa strongly resemble some of the Murices. The fifth division being composed entirely of land shells, and the animal inhabiting them being oviparous, they might with greater propriety be classed with the genus Helix. The B. terebellum, the only species of the sixth division, is a remarkable exception to the general form of the Bulla; it is a long and slender shell, and not unlike a lengthened olive.

Some species of this genus, particularly those of the fifth division, are banded with party-colored streaks, but by far the greater number are colorless.

The B. volva or true Weaver's Shuttle, is one of the most rare shells of the genus. The B. imperialis, which has a pink interior, is also considered rare. The reverse varieties of the fifth division are also highly valued.

The different species of Bulla are found in almost every part of the world.

This genus derives its name from the resemblance which some of the lesser species have to a bubble of water (Bulla).

Division I.-Shell resembling the Cypraa genus, but toothed on the outer lip only.

\section{Scientific Name. Locality. Common Name.}

Ovum ......... Amboyna, India, China . Egg Dipper ...

Imperialis ...... South Seas ........... Crumpled . do ..

Nucleus ....... Mediterranean, Africa .. Wrinkled . do ..

Verrucosa ..... Amboyna, China..... Warty ... do ... 
Division II.-Shell oblong, beaked at the ends.

\begin{tabular}{|c|c|c|}
\hline Scèntific Name. & Locality. & Common Name. \\
\hline Volva ........... & Japan, China ........ & Weaver's shuttle \\
\hline Lepida.......... & Africa, Leghorn........ & Orange.... do .. \\
\hline Birostris ....... & Java, China ............ & Lesser .... do . \\
\hline Secale...... & Americau Seas, Jamaica & Rye shap'd do .. \\
\hline Spelta ......... & Mediterranean......... & Oblong.... do .. \\
\hline Gibbosa ......... & 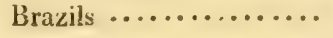 & Belted .... do .. \\
\hline
\end{tabular}

Drvision III.-Shell thin, gibbous, and aperture large.

FAMrLY 1.-Apex generally umbilicated and without a spire.

\begin{tabular}{|c|c|c|}
\hline Natucum ....... & Amboyna, Africa, Asia .. & a nut $\cdots$ do \\
\hline Aperta ........ & Cape of G. Hope, Britain & Wide..... do \\
\hline Catena........ & Devonshire ........... & Chain ..... do \\
\hline Plumula....... & 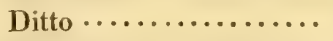 & Feather... do \\
\hline Hydatis ........ & Mediterranean, Britain .. & Pap \\
\hline Ampulla....... & a, East Indies ... & t's.egg do \\
\hline Amygdalus...... & West Indies, Niger...... & nd... do \\
\hline Lignaria ........ & Adriatic, Britain ....... & Bro \\
\hline Pectinata ....... & Denmark ........ & lated $\cdot$ do \\
\hline Soluta......... & Ceylon ......... & aled .. do \\
\hline Akera......... & Norway, Britain ........ & Elastic ... do \\
\hline Cylindrica ..... & South Seas........... & Cylindric . \\
\hline
\end{tabular}

Shells Minute.

Cylindracea .... Britain ............ Cylindrical do ..

Umbilicata ..... Ditto .............. Umbilicated do ..

Retusa........ Ditto ............. Blunt .... do ..

Obtusa ........ Ditto.......... Obtuse ... do ..

FıMILY 2.-Having a spire.

Physis ........ East Indies, South Seas .. Striped ... do .. Amplustre ..... China, Molıccas....... Banded.... do .. 
Scientific Name.

Zonata..........

Undulata........

Scabra
Locality.

Tranquebar............ Zoned Dipper...

................. Undulated do .

Java ............... Rough .... do ..

Division IV.-Shell pyriform, with produced beak.

Ficus......... Indian Ocean, Amboyna Fig ..... do .. Pyrum .......................... Pear .... do .. Rapa ........ Ámboyna, Asiatic Ocean Turnip shap'd do Canaliculata .... ............... Channelled do..

Drvision V.-Shell generally thin, spire prominent, and body whorl inflated.

Voluta......................... Volute ... do ..

Dominicensis .... St. Domingo ......... Nine whorl'd do..

Crassula ...... Virginia, West Indies .. Reversed .. do ..

Fontinalis ..... Britain ............. Fresh water do ..

Rivalis........ Ditto............. River.... do ..

Hypnorum ..... Ditto .............. Slender ... do ..

Gelatinosa ..... Denmark ............ Gelatinous do ..

Virginea ...... West Indies .......... Ribbon ... do ..

Fasciata ....... East and West Indies .... Banded ... do ..

Strigata ...... ................ Yellow streaked

Striatula ...................... Striated .. do ..

Exarata...... Guinea .......... Wrinkled . do ..

Truncata ....................... Truncated. do ..

Priamus ....... Guinea, West Indies .... Priam .... do ..

Zebra ........ Ditto.............. Zebra.... do ..

Achatina ...... E. Indies, Africa, America Broad strip'd do ..

Purpurea....... Africa ............. Purple mouth'd do

Sinistrorsa ..... Ditto ............. Great revers'd do.

Division VI.-Shell cylindrical, with a subulate spire and truncate base.

Terebellum .... Amboyna ........... Aw shap'd do .. 


\section{VOLUTA._VOLUTE OR WREATH.}

DESCRIPTION OF PLATE XXII.

Drv. I. - Fig. 5. V. glabra. Drv. V. - Fam. 1. Fig. 7. V. papalis.

Div. II. -Fig. 3. V. marginata. Drv. VII.-Fam. 1. Fig. 8. V. vexillum.

Drv. III.-Fig. 2. V. persicula. Drv.VIII.-Fam. 1. Fig. 1. V. ethiopica. Drv. IV.-Fig. 4. V. cruenta. Drv. IX. -Fig. 6. V. cancellata.

Shell one-celled, spiral; aperture without a beak, and somewhat effuse; pillar twisted or plaited, generally without lips or perforation.

THE genus Voluta is as remarkable for the beauty, as for the variety of its species; it also presents a great diversity in form, but the shells may easily be recognised by an attention to the following distinctive character.

The Volutes have, without any exception, several teeth or plaits on the columella or pillar lip. The number of teeth is by no means uniform: on some there are only four or five, while in others, particularly in those of the fourth division, they fiequently amount to fifty; and it may be remarked, that the teeth are less articulated according as they are more numerous.

The divisions of this genus are founded principally on the great diversity of external character. The first comprehends those species which have an ovate form, and the aperture entire, resembling the shape of the liuman ear: the greater part of which are land-shells. The distinction of the second division is, that the outer margin is thickened, and the aperture not quite entire. In the third the aperture is effuse and linear. The shells of 
the fourth division have a subcylindrical form, and ines clude the numerous varieties of Olives. The shells of the preceding divisions are generally smooth, but in the folm lowing they are more or less striated or ribbed. The fifth is by far the most numerous class-it contains the fusiform Volutes, usually known by the name of Mitres, some of which are very elegantly formed and finely tinted in their coloring; the most distinctive species are the $\mathbf{V}$. sanguisuga and $V$. papalis. The $V$. mercatoria is a characteristic example of the sixth division, which is distinguished by having the outer lip denticulated. The seventh contains some of the most interesting' shells of the genus, among which the V. musica, and V. ebræa, are conspicuous for their markings, which in the former resemble the notes used in music, and in the latter are similar to oriental characters. The papillary summit of the shells of the eighth division, which are usually called Melons, is a very marked distinction. The species are generally of a large size, and some of them, as the V. ethiopica, have their whorls surrounded with elevated hollow spines, encircling the spire with a crown. Of the remaining divisions the tenth forms an exception to the general smoothness of the Volutes, its species being extremely rugged and nodulous.

Among the more beautiful species of the genus the V. vexillum or Orange Flag Volute, is most to be admired. The V.junonia, V. lapponica, V. scapha, and V. magellanica, are highly valued for their rarity and beauty.

There is a considerable difference in the dimensions of the Volutes, some being very minute, while others attain to a great size.

The different species of the $\mathrm{Voluta}$ are met with in vari- 
ous parts of the world; the Indian seas produce the most, and some are found in the Atlantic, Pacific, Northern, and European oceans.

The form of the shells of this genus has suggested the name of Voluta, signifying rolled up cylindrically.

Dovision 1.-Shell ovate, with the aperture generally car-shaped and enitive.

\begin{tabular}{|c|c|c|}
\hline Scientific Name. & & \\
\hline Auris-Midæ..... & $\begin{array}{l}\text { E. Indies, Salt marshes, } \\
\text { Ceram ............. }\end{array}$ & Midas' ear Vol \\
\hline uris-Judæ .... & Moluccas, Fens in India. & do .. \\
\hline ...... & nd, N. Caledonia & N. \\
\hline Achi .... & ............. & $\mathrm{Ma}$ \\
\hline ....... & & \\
\hline$i \ldots$. & $\cdots$ & Sil \\
\hline ..... & Aus & \\
\hline is ... & East Indies ............ & \\
\hline Alpina ... & St. Helena $\ldots \ldots \ldots \ldots$ & \\
\hline ti $\ldots . .$. & ....................... & $\mathrm{C}$ \\
\hline ....... & England $\ldots \ldots \ldots \ldots$ & Do \\
\hline (n...... & ........ & \\
\hline$\cdots$ & ern Ocean, China . & \\
\hline a........... & Africa $\ldots \ldots \ldots \ldots \ldots$ & \\
\hline Coffea......... & Barbadoes.............. & Coffee-color do \\
\hline
\end{tabular}

Minute Shells.

Minuta....... Barbadoes ........... Minute.... do .. Flava ........ East Indies .......... Yellow ... do ..

Denticulata ..... Great Britain ......... Toothed .. do .. Triplicata ..... Guernsey ............ Three-tooth'd do Pusilla........ ................. Small oval - do .. Bidentata ...... Scotland, Devonshire ... Double-tooth'd .. Alba ......... Sandwich, Sheppy 1sland White.... do .. Pellucida ...... Salcomb Bay, Devon ... Pellucid .. do .. Unidentata..... Devonshire ......... Single-tooth'd do 
Scientific Name.

Interstincta.....

Insculpta........

Plicatula........

Ambigua .......
Locality.

Bigberry Bay, Devon .. Divided Volute .

Devonshire ........... Engraved . do ..

Ditto ............. Plaited ... do ..

Ditto .............. Doubtful .. do ..

Drvision II.-Shell ovate, smooth, outer margin thickened, aperture nearly entire.

\begin{tabular}{|c|c|c|}
\hline legans ...... & & rant $\cdots$ \\
\hline llida ......... & , Britain .... ... & Pallid .... do \\
\hline xilis ......... & Senegal.......$\ldots$. & Brown banded \\
\hline onilis ........ & 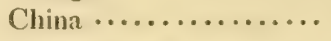 & Nec \\
\hline ia $\ldots \ldots \ldots$ & erranean ........ & $\mathrm{Mi}$ \\
\hline uttata $\ldots \ldots \ldots$ & $a \ldots \ldots \ldots \ldots \ldots$ & Do \\
\hline Marginata ..... & $\ldots \ldots \ldots \ldots \ldots$ & \\
\hline 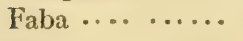 & $y \ldots \ldots \ldots \ldots$ & Bea \\
\hline trigata.... & 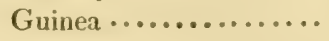 & \\
\hline$m \cdots \cdots$ & G & \\
\hline nitzii ..... & ea $\ldots \ldots \ldots \ldots$. & $\mathrm{Ch}$ \\
\hline la $\ldots \ldots \cdot \cdots$ & $\ldots \ldots \ldots \ldots \ldots$ & \\
\hline Picta .......... & Brazils...$\ldots \ldots \ldots$ & d $\cdots$ \\
\hline astanea ....... & Ditto $\ldots . . . \ldots \ldots \ldots$ & \\
\hline
\end{tabular}

Division III.-Shell ovate, smooth, spire flat, aperture effice and linear.

Porcellana ..... Indian Ocean ......... Porcelain.. do .. Persicula...... African Ocean ....... Red spotted do .. Cingulata...... Cape Verde, Goree .... Red-lined . do .. Bullata ....... East Indies ......... Bubble ... do .. Lævis ........ Devon, West Indies .... Smooth ... do .. Catenata ..... England, West Indies .. Chain-spotted do 
Division IV.-Shell sub-cylindrical, enamelled, and emarginuted.

Family 1.-Spire rather obtuse.

Scientific Name.

Porphyrea .....

Erythrostoma .. Amboyna, Mauritius, S.

Seas...$\ldots \ldots \ldots$ Orange mouth'd

Oliva ....... Ditto, South Seas, Brazils,

East \& West Indies .. Olive ..... do ..

Ventricosa ..... Mindana, Moluccas .... Ventricose do ..

Incrassata ..... Moluccas, Brazils ..... Thickened do ..

Pinguis ....... Brazils ............ Quaker ... do ..

Tigrina ....... Eastern Ocean ........ Tiger .... do ..

Carneola ....... Moluccas ........... Carnelian . do ..

Micans ....... Ditto, Mauritius ..... Little.... do ..

Faмux 2.-Spire prominent or conical.

Cruenta ....... Amboyna, Mauritius .... Orange-throat do. Annulata ...... Ditto ............... Ringed ... do ..

Gibbosa ....... Coromandel, Madagascar Gibbous .. do .. Ispidula ....... Moluccas ........... Enamelled . do .. Hiatula ....... Africa............. Gaping ... do .. Ampla......................... Large $\ldots .$. do .. Nivea ........ West Indies ......... Snowy ... do .. Jaspidea ....... Philippines .......... Jasper .... do .. Ancilla ......................... Damsel ... do .. Nitidula ....... Ditto, Moluccas, Mauritius Delicate .. do .. Oryza ........................... Rice.... do

Drvision V.-Shell fiesiform, generally striated or ribbed, either longitudinally or transversely.

Famuy 1.-Spire less than half the length of the shell. Crenulata...... East Indies ......... Crenulated do.. 
Scientific Name.

Fenestrata .....

Dactylus........

Conus

Texturata ......

Microzonias ....

Tringa .........

Fissurata........

Barbadensis ....

Spadicea .......

Decussata ......

Variegata......

Caffra ..........

Leucozonias ....

Morio ..........

Aurantia ........

Vitulina ........

Olivaria ........

Nubila.........

Pertusa .......

Spiralis .......

Patriarchalis ...

Muriculata ....

Paupercula .....

Pica ...........

Ferrugata .....
Common Name.

$\begin{array}{ll}\text { Indiau Seas ......... Eight-plaited V. } & \text { Eix-plaited do . } \\ \text { Bengal, India, China ... } & \text { Six- }\end{array}$ .................. Conic ... do ..

................... Four-plaited do ..

Indian Ocean ......... White banded do

Mediterranean......... Decorticated do

................. Straw-color'd do

Barbadoes ............. Striped ... do ..

Five-plaited do ..

Decussated do ..

Variegated do..

Caffre .... do ..

West Indies .................... Tawny .... do .

................... Orange.... do ..

Indian Seas ......... White-banded do

................... Two-banded do .

Friendly Isles ......... Clouded .. do ..

East Indies ........... Punctured do ..

Indian Seas .......... Spiral .... do ..

East Indies .......... Patriarch . do ..

Indian Ocean .......... Walled.... do ..

Mediterranean ........ Zebra .... do ..

St. Bartholomew ..... Magpie ... do ..

Bellied.... do ..

\section{FaMiLy 2.-Spire half the length of the shell.}

Cornicula ..... Mediterranean, W. Indies Horn-color do Schroeteri ..... Guinea ............. Schroeter's do.

Crenifera ...... Indian Seas .......... Crenated .. do ..

Seabricula ..... China ............. Roughly-striated

Ruffina ....... East Indies .......... Reddish yellow

Vulpecula ..... Amboyna ........... Foxy .... do ..

Castellaris ..... East Indian Ocean .... Chequered do ..

Subdivisa ...... ................. Subdivided do ..

Melongena ..................... Fine ribbed do ..

Plicaria ...... China ............. Folded ... do ..

Rugosa ...... Indian Ocean ........ Rugose .... do ..

Scutulata ..................... Scutcheon do.. 
UNIVALVES—VOLUTA.

Scientific Name.

Nigra

Casta ..........

Serpentina ......

Digitalis ......

Episcopalis......

Papalis .........

Thiara

Coronata
Locality.

Guinea

Amboyna

Indian Ocean .........

Ditto ..............

Ditto, China, Mauritius .

Amboyna ............

Madagascar ..........

West Indies
Common Name.

Black Volute ..

Brown.banded do Serpent ... do .. Fingered .. do .. Mitre.... do .. Pope .... do .. Thiara ... do .. Crown .... do ..

Shell less than half an inch in length.

Maculosa........

Biplicata

Turricula

Lineata ........

Sulcata ......

Discors .......

Striata ........

Lavigata .......

Ocellata

Nasuta.........

Marmorea

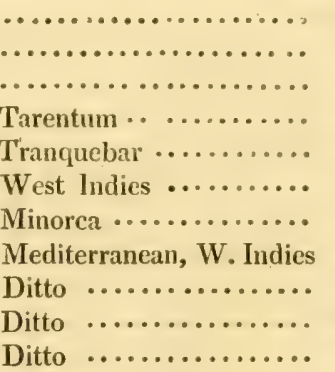

Spotted ... do .. Two-plaited do .. Tower ... do .. White-lined do .. Sulcated .. do .. Discordant do.. Striated .. do .. Smooth ... do .. Eyed .... do .. Black-spotted do Marbled .. do ..

\section{FaniLy 3.-Spire more than half the length of the shell.}

\begin{tabular}{|c|c|c|}
\hline Acuminata ...... & Tranquebar ........... & Sharp pointed do \\
\hline Virgo .......... & 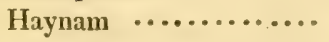 & Virgin $\ldots$ do .. \\
\hline Filaris ......... & 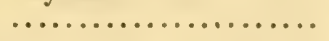 & Narrow ... do .. \\
\hline Filosa ......... & East Indies .......... & Threaded - do \\
\hline Clathrus ........ & 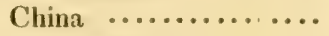 & Cancellated do \\
\hline Exasperata ..... & East Indies ........... & Granulous - do \\
\hline Costata ..... & $\ldots \ldots \ldots \ldots \ldots \ldots \ldots$ & ed ... do \\
\hline Granosa ....... & East Indian Ocean ...... & Grained .. do \\
\hline Nodulosa ....... & West Indies .......... & Nodulous - do \\
\hline Sanguisuga $\ldots$. & $\begin{array}{c}\text { Amboyna, Mediterranean, } \\
\text { Sonth Wales ....... }\end{array}$ & Leech \\
\hline Polygona ....... & $\ldots \ldots \ldots \ldots \ldots \ldots$ & Polygonal · do \\
\hline Taeniata ........ & 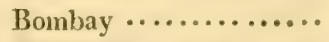 & Ribbon.... do \\
\hline Cruentata .... & Indies ........... & notty ribbed \\
\hline
\end{tabular}


Scientific Name.

Turrita

Acus

Abbatis
Locality. .................. Turreted Volute

................... Needle $\ldots$... do ..

East Indies ........... Abbot.... do ..

Drvision VI.-Shell small, thick, strong, having the outer lip denticulated, and rather angular.

Mercatoria..... Mediterranean ........ Clouded .. do .

Ziervogelii ...................... Thick-lipped do

Rustica....... Mediterranean,Barbadoes

Africa ............ Rustic.... do ..

Torva ......... Barbadoes .......... Rough ... do ..

Mendicaria ..... Mediterranean ........ Black \& white do

Nana ........ Mediterranean ....... Dwarf ... do ..

Division VII.-Shell emarginate, effuse, and spire rather papillary.

FamiLy 1.-Whorls nodulous or plain.

Musica ........ American Ocean, E.\& W.

Indies ............ Music .... do ..

Virescens ...... Guinea ............ Grcenish .. do ..

Plicata ....... East Indies ......... Plaited .... do ..

Ebræa........ Asiatic Ocean, Jamaica.. Hebrew-character

Vespertilio ...... Amboyna, E.\& W. Indies Bat...... do ..

Flavicans ...... East Indies .......... Yellowish do..

Nivosa ....... New Holland ........ Snow-spotted do

Vexillum ...... Amboyna, Ceylon, E. Ind, Banner ... do ..

Lapponica..... American Ocean, East \&

West Indies ......... Spotted .. do ..

Junonia ....... South Pacific Ocean ... Peacock ... do ..

* Harpa ...... Ditto ............. Lyre .... do ..

Magnifica ..... New Holland, South Seas Magnificent do.. 
UNIVALVES — VOLUTA.

Scientific Name.

Locality.

Common Name.

Volva

Guinea

(n)

Whitish .. do ..

Undulata ...... South Seas ......... Undulated do ..

Magellanica .... Magellan, Falkland Isles Magellanic do..

Rupestris ..... Japan ............ Lightning . do ..

Pacifica ....... South Seas ......... Pacific.... do ..

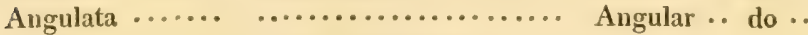

Scapha ........ Cape of Good Hope ... Clouded .. do ..

Colocynthis .... Brazils ............. Coloquint . do ..

Famry 2.-Whorls crowned with spines.

Imperialis ..... Moluccas, Philippines .. Imperial .. do ..

Vespertilio ..... East Indies .......... Bat.... do ..

Drvision VIII.-Shell ventricose, and the summit of the spire papillary.

FamrLy 1.-Spive coronated or nodulous.

Ethiopica ..... P. Gulf, China, Amboyna Ethiopic .. do ..

Diadema....................... Diadem .. do ..

Tessellata ...................... Tessellated do ..

Corona ....... Indian Ocean ......... Ducal-crown do..

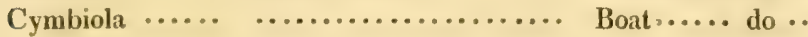

Famisy 2.-Spire chonnelled.

Olla ......... W. Indies, Mediterranean Melon .... do ..

Rubiginosa..... Coast of Peru ........ Ochreous.. do ..

Cymbium ..... Spain, Senegal, Guinea - Cup like .. do ..

Neptuni ....... Persian Gulf, Africa ... Neptune's - do .

FamiLx 3.-Spire truncated.

Porcina....... Spain, Africa ......... Keel-margin do.. 
FamiLy 4.-Shell formed by one broad whort.

\begin{tabular}{|c|c|c|}
\hline ntific Name. & Locality. & Common Name. \\
\hline & $\ldots \ldots \ldots \ldots$ & \\
\hline
\end{tabular}

FamiLy 5.-Spire nearly buried in the body whorl.

Melo ......... East Indies, China..... Melon .... do..

Drvision IX.-Shell nearly entire, longitudinally or transversely ribbed and subumbilicated.

Reticulata ..... Africa, Jamaica ....... Reticulated do..

Cancellata...... Mediterranean ........ Latticed - do ..

Nassa ......... Guinea .............. Ribbed ... do ..

* Fusca ....... South Seas ........... Tawny.... do ..

Nucea.......................... Nut ... .. do ..

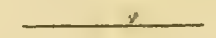

Division X.-Shell spinous, or rugged and nodulous.

Turbinellus ..... Amboyna............. Turbinated do..

Capitellum ..... Indian Ocean ......... Ridged ... do ..

Rhinoceros ..... New Guinea .......... Rhinoceros do..

Muricata ..... Jamaica, Madagascar .. Prickly ... do ..

Ceramica ...... Ceram, Indian Ocean .. Horned ... do ..

Globosa ......................... Globose .. do ..

Drvision XI.-Shell with a somewhat produced beak.

Pyrum ........ Ceylon ............... Pear-shaped do..

Gravis ........ Moluccas ............ Solid ..... do ..

Scolymus ...... Florida .............. Artichoke . do .. 
BUCCINUM. - W HELK.

DESCRIPTION OF PLATE XXIV.

Drv, I. - Fam. 1. Fig. 3. B. dolium.

Drv. IV.-Fam.2. Fig. 1. B. decussatum.

Drv. V.-Fam.2. Fig. 2. B. papillosum.

Div. VI.-Fam. 1. Fig. 5. B. pullus.

Div. VII. -Fig. \%. B. harpa.

Drv. VIII.-Fam. 1. Fig. 6. B. monodon.

Drv. XIII._Fig. 4. B. spiratum.

Drv. XVI.-Fam. 1. Fig. 8. B. maculatum.

Shell univalve, spiral, gibbons; aperture ovate, terminating in a short canal, leaning to the right, with a retuse beak or projection: pillar-lip expanded.

THIS genus is rendered difficult to separate from the Murex, by a striking similarity of form in some of its species. The leading distinction of the Buccintim is its beak or canal, which is usually much shorter than that of the Murex, and also inclines to the right: the shape of the former being more gibbous, constitutes another distinctive character.

Of the numerous divisions of this genus, the first is composed of those shells which are commonly known by the name of Tuns; they have a brittle and light structure, and although some of them grow to a large size, they retain their characteristic fragility and thimness; their form is almost invariably globose.The B. dolium, B. olearium, and B. galea, are the most common species; the latter of which sometimes exceeds ten inches in diameter. 
The Helmets, which compose the fourth division, are nearly allied to the Tuns, but they may be distinguished from them by having both of their lips (with few exceptions) furnisher with a number of strong and articulated teeth; the exterior is also covered with prominent protuberances or knobs. Among the species of this description may be enumerated the three following: B. plicatum, B. cornutum, and B. rufum, the latter of which is remarkable for the glowing rerl color of its mouth.

The shells of the seventh have their exterior longitudinally ribber, they include the species usually called Harps, of which the most beautiful and rare is the $B$. costatum, more frequently called the Many-ridged Harp.

In the eighth division, the aperture being very wide and open, as in the B. monodon, B. persicum, and B. patulum, the species have been designated Scoops.

The form of the B. undatum (the common English whe!k) characterizes the tenth division; the B. spiratum is remartmhle for laving its whorls channelled or spirally grooved, and the B. lapillus for the durable purple dye which its animal produces.

The frtcenth division contains only two species; which have their whorls sumonnted with rows of foliations. The sixteenth division is more distinct than any hitherto enumerated ; it comprises those shells which are generally known by the name of Needles; they are remarkable for their sharp, lengthened, and spiral form. 
The B. maculatum, which is often nine or ten inches long, may be adduced as an illustrative specimen.

Many of the species are extremely rare; but the most beautiful and valuable is the B. costatum.

The African, American, Indian, Eniopean, and Southern oceans, produce the greater number of Buccina, and many are found in the British and Mediterranean Seas.

This genus derives its name from some of its species being formed like a trumpet (Buccinum).

Divisron I.-Shell infated, rounded, thin, slightly transiarent und brittle.

FamiLy 1.-Aperture without teeth.

Scientific Name.

Olearum .........

Galea

Perdix

Doliun

Caudatum

Locality. East Indies, China ..... Tun .......... Mediterranean ........ Brown Tun ..... America, South Seas,

Amboyna .......... Partridge.. do .. Mediterranean, Amboyna Spotted.... do .. ................... Beaked ... do .

FAмILY 2.-Outer lip toothed.

Sulcosum ..... Coromandel, China .... Flat ribbed do .. Chinense ...... China, Java ........ Chinese .. do ..

Divisıon II.-Shell ovate, ribbed, aperture rather contracted, pillar lip thickened and strongly wrinkled, and outer lip toothed, thickened, and marginated.

Pomum ........ Amboyna, China ...... Thick lipp'd do Ringens ..................... Grinning . do .. 
Drvision 1Il.-Shell with tuberculated belts or ribs, pillar lip spread, and beak much produced and reflected.

Scientific Name.

Locality.

Common Name.

Echinophorum .. Mediterranean ........ Tuberculated Tun

Nodosum ...................... Belted ... do ..

Rugosum ...... Mcditerranean ....... Rugged ... do ..

Division IV.-Shell with an exserted reflected beak, pillar lip spread, and the outer lip unarmed outwardly.

FamLY 1.-With the spire truncated, aperture rather linear, pillar lip much spread, the pillar slightly wrinkled, and outer lip thickened.

Corrugatum .... ................. Wrinkled Helmet

Plicatum ...... Jamaica, Ascension Island Plaited .... do ..

Tlammeum ..... Jamaica, West Indies ... Triangular do ..

Rufum ....... Madagascar ......... Red ..... do ..

Testiculus ..... Jamaica ........... Bonnet ... do ..

Fanil 2.-With the spire rather clevated, pillar lip thinly spread, pillar slightly wrinkled, and outer lip thickened.

Decussatum .... Mediterranean ........ Decussated do..

Areola ........ Ditto, E. Indies, Amboyna Draft-board do ..

Strigatum ...... Ditto ............. Yellow striped

Saburon ....... Mediterranean, Goree .. Grey .... do ..

Abbreviatum ... ................. Shortened do..

Fanily S.-Resembling the serond, except having the pillar lip granulated.

Granulatum .... Mediterranean, W. Indies Granulated do .. Undulatum .... Ditto, Barbadoes ..... Undulated . do .. 
Fanux 1.-Resembling the third, but having the pillar lip granulated and wrinkled.

Scientific Name. Locality. Common Name.

Inflatum ....... Indian and African Seas , Inflated Helmet Tessellatum ..... Amboyna, S.Seas, Guinea Tessellated do .. Bilineatum ..... Weymouth .......... Smooth net do .. Cicatricosum .... Indian Ocean ........ Cicatrix .. do ..

Famis 5.-With the pillar lip smooth.

Recurvirostrum .. Barbadoes ........... Recurved beak do Cassis ........ Bay of Naples ....... Helmet ......

Division V.-Shell resembling the last division, but the outer lip, on the outside, is muricated at the base.

Fanrux 1.-With the spire short.

Erinaceus ..... Tranquebar, China, American Ocean ......... Hedgelıg do ..

Biarmatum ....................... Knobbed .. do .. Fimbria ....... East Indies ........... Bordered .. do .. Glaucum ....... Amboyna, China ....... Yeliow ... do .. Vibex ....... East and West Indies, Tranquebar .......... Agate...... do..

FamiLy 2.-With the spire elevated.

Papillosum ..... Indian \& Asiatic Oceans . Prickly lip do .. Glaus ........ Ditto .............. Thread girded do Mutabile ...... Senegal ........... Changeable do .. Gibbum ....... Mediterrancan, Amboyna Hunchbacked do 
Division VI. - Shell with the pillar lip dilated and thickened, and aperture wide.

Famiry 1.-With the pillar lip mueh thickened and dilated.

\begin{tabular}{|c|c|c|}
\hline Scientific Name. & Locality. & Common Name. \\
\hline reularia ........ & $\begin{array}{c}\text { China, Amboyna, Mau- } \\
\text { ritius ................ }\end{array}$ & Broad lipped B. \\
\hline ronatum ...... & Madagascar ............. & Crowned.. do .. \\
\hline epaticum ....... & Dorsetshire $\ldots . . . \ldots \ldots$ & Small knobb'd dc \\
\hline llus....... . & $\begin{array}{c}\text { Mediterranean, Malacca, } \\
\text { Senegal .............. }\end{array}$ & Young .... do .. \\
\hline & Asiatic Ocean .......... & Pale olive $\cdot$ do. \\
\hline errucosum ..... & Ceylon, Madagascar .... & Warty... do.. \\
\hline Gibbosulum .... & $\begin{array}{l}\text { Mediterranean, Asiatic } \\
\text { Ocean .............. }\end{array}$ & Gibbous .. do .. \\
\hline th & East Indies......$\ldots$. & Latticed .. do . \\
\hline & Tranquebar ........... & Cancellated do .. \\
\hline & East Indies ......... & Acuminated do .. \\
\hline
\end{tabular}

FaMILY 2.-With the pillar lip spread, but not very thick.

Textum

Reticulatum … Britain, Mediterranean,

Azores............. Reticulated do ..

Ambiguum ..... Britain .............. Small plaited do

Macula........ Norway, Britain ...... Spot-lipped do ..

Stolatum........ Tranquebar........... Brown-banded do

Plicatulum ..... East Indies .......... Plaited .... do ..

Piscatorium ..... Ditto ............... Knobbed . do ..

Mauritii ........ Mauritius ............ Six-toothed do ..

Armillatum ..... .................. Brown ... do .

Nitidulum ..... Mediterranean, Goree .. Thin banded do .

Ventricosum .... St. George's Bay ..... Ventricose do..

FaMiLy 3.-Obtuse, convex, depressed, and smooth.

Neriteum ...... Mediterranean ........ Nerite-shaped do 
Division VII.-Shell with longitudinally keeled, mucronated ribs, pillar smooth.

Scientific Name.

Locality.

Common Name.

Harpa........ East Indies, Mauritius, Amboyna........ Harp......

Cancellatum .... Tranquebar.......... Latticed Harp ..

Crenatum ..... Mauritius........... Crenated . do ..

Costatum ..... Philippine Isles ...... Many-ridged do

Division VHI.-Pillar lip appearing as if worn flat, aperture very vide and open.

Faminy 1.-Armed with a subulate tooth at the base.

Monodon ....... South Seas, Cape Horn - One-toothedScoop Imbricatum .... South Seas .......... Imbricated do .. Crassilibrum .... .................. Thick-lipp'd do .. Narval ....... South Seas ......... Unicorn ... do .. Cingulatum .... Peru .............. Belted .... do..

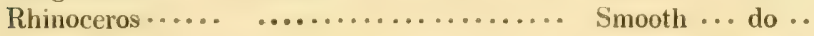

Family 2.-Without the tooth, and the outside striated.

Haustrum ..... New Zealand ........ Scoop .......

Persicum ...... Asiatic Ocean, Amboyna Persian ... do ..

Sertum ....... Ditto, Red Sea ....... Chesuut .. do ..

${ }^{*}$ Vexillum $\ldots \ldots$. ................ Flag $\ldots .$. do ..

Famixy 3.-With the outside tuberculated.

Patulum ....... E. \& W. Indies, America Wide-mouth'd do Luteostomum ... South Seas, China .... Pallid .... do .. Hæmastoma .... European, Mediterrancan, and Asiatic seas ...... Red-lipped do ..

Armigerum .... South Seas........... Armed .... do ..

Dentex ...................... Toothed .. do .. 
Division IX. - Shell with spire obliquely recurved, aperture vory large, outer lip reflected, and pillar lip with two obsolete teeth at the base.

Scientific Name. Locality.

Common Name.

Concholepas.... Peru, Magellan ...... Limpet-shap'd S.

Division X. -Shell coarse, spire acute, aperture ovate, pillar lip smooth and flattish.

Lapillus ....... Britain, Norway, Azores Common Whelk Varium ....................... Varied ... do ..

Undatum ..... Britain, Norway ...... Wave-ribbed do

Ciliatum ...... Greenland .......... Ciliated .. do ..

Solutum ...... ................ Unequal ribbed

Porcatum ...... Mexico ............. Rugged .. do ..

Papyraceum .... Norway ............. Paper .... du ..

Otaheitense .... Otaheite ............ Otaheite .. do ..

Glaciale ....... Northern Ocean ....... Keel-ridged do ..

Carinatum ..... Spitzbergen ......... Carinated . do ..

Filosum ....................... Threaded . do ..

Sulcatum ..... Tranquebar.......... Grooved .. do ..

Smaragdulus .... Ditto .............. Emerald ... do ..

Undosum ...... Amboyna ........... Undulated do ..

Affine ......... South Seas, Moluccas ... Brown-striped do

Fumosum ..... ................. Smoky .... do ..

Tranquebaricum Tranquebar .......... Tranquebar do...

Cruentatum .... . ................ Red-spotted do ..

Pyrozonias ...................... Double.streaked

Versicolor ..... East Indies .......... Lurid .... do ..

Lamellosum .... New Zealand ........ Lamellar . do ..

Lamellatum .... ................ Lamellated do ..

Crispatum .................... Wrinkled . do .. 


\section{Drvision Xl._Shell strongly ribbed transversely.}

Scientific Name.

Orbitum $\ldots . . .$. .

Scala $\cdots \cdots$. . .

Indicum
Localty.

New Zealaud ......... Globose Whelk

East Indies ........... Broad-belted do

Ditto........... Indian .... do ..

Division XII.-Shellsub-globose, ponderous, aperture large, pillar lip very thick.

Plumbeum ..... California .......... Double-groov'ddo

Crassum ..................... Thick .... do ..

Drvision XIII.-Shell with the pillar abrupt and strongly umbi-

licated.

Spiratum ...... E. Indies, Mediterraneau, Arabia ............. Acute spire do..

* Eburneum .... China ............. Spotted ... do ..

Zeylanicum ..... Ceylon .............. Ceylon ... do ..

Glabratum ..... Tranquebar........... Glossy .... do ..

Division XIV.-Shells somewhat polished and not enumerated in the former divisions.

Tigrinum ...... New Zealand ........ Tiger.... do ..

Turgitum ..... Ditto .............. Red-spotted do ..

Scutulatum .... Ditto .............. Streaked .. do ..

Testudineum .... Ditto.............. Tortoise-shell do

Cochlideum .... South Seas ........... Indented spire do

Catarracla ..... N. Zealand, C. G. Hope Long-striped do . 
Scientific Name.

Lrevissimum ...

Cyaneum .......

Læve ........

Igneum .......

Lyratum $\cdots . .$. .

Plumatum .......
Locality.

East Indian Seas ...... Polished Whelk

Greenland .......... Blueish.... do ..

East Indies ......... Emooth ... do ..

$\ldots \ldots \ldots \ldots \ldots . . . . . . \quad$ Red streaked do

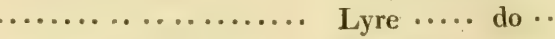

Jamaica............ Painted ... do ..

Iinute Shells.

Glaberrimum ...

Nucleus ...... N. Zealand, Madagascar

Lineatum...... Britain, West Indies ....

Exile ................................

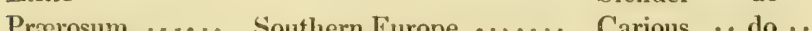

Cinctum ...... Britain ............ Minute... do ..

Minimum ........................... Lesser ... do ..

Division XV.-Shell roundish, spive flat, whorls lamellated or spinous, beak produced and umbilicated, and aperture large.

Bezoar ..........

China

Bezoar's .. do ..

Bulbosum ...... Tranquebar .......... Bulbous ... do ..

Division XVI.-Shell turreted, subulate, and slightly polished.

FamiLy 1.-Whorls entire.

Maculatum. ... Africa, E.Indies, Amboyna Spotted Needle .

Oculatum ..... East Indies .......... Oculated .. do ..

Subulatum ..... Ditto, Amboyna, China . Awl-shap'd do ..

Felinum .......................... Cat .... do

Vittatum ...... Ceylon ............. Ribbon ... do ..

Digitale ....... Bombay, Senegal ..... Bluish-banded do

Concinnum ..................... Belt-spotted do .. 
UNIVALVES — BUCCINUM.

Scientific Name.

Cinereum

Locality.

Succinctum ....

Lanceatum .....

Murinum... .

Hastatum $\cdots .$. .

Sinuatum $\ldots . .$. .

Bifasciatum

Radiatum ......

Virgineum .......

Acicula
Amboyna ........... Steel-grey Needle

East Indies .......... Girdled .. do ..

Ditto, Amboyna ........ Lancet .... do ..

Africa $\ldots . . . . \ldots \ldots$ Mouse-color'd do

................... Javelin ... do ..

East Indies ........... Twisted .. do ..

Ditto ................ Two-banded do

Coast of Naples ....... Radiated .. do ..

Virginia .............. Fresh water do ..

Britain, Paris ......... Minute-pointed do

Famix 2.-Whorls divided by a transverse line or furrow.

Crenulatum .... China ............. Crenulated do ..

Hecticum ..... Africa ............ Hectic .... do ..

Geminum ..... ............... Divided ... do ..

Proximatum .... ................. Glossy .... do ..

Monile ........................ Necklace - do ..

Strigilatum .... Asiatic Ocean ......... Strigilated do ..

Duplicatum .... Indian Ocean, Haynam - Double whorl do

Acus ........................ Needle .......

Dimidiatum .... China .............. Orange \& White

Pertusum .................... Hollow dotted do 

UNIVALVES —STROMBUS.

STROMbUS. - Wraged or Claw-Shell.

\author{
DESCRIPTION OF PLATE XXV. \\ Div. I. -Fig. 4. S. cliragra. \\ Drv. II.-Fam. 1. Fig. 2. S. polyfasciatus. \\ Fam. 1. Fig. 3. S. granulatus. \\ Drv. V.-Fam. 2. Fig. 5. S. palustris. \\ Div. VI.-Fig. 1. S. oniscus.
}

Shell univalve, spiral; aperture much dilated; the lip expanding, and produced into a groove leaning to the left.

THE distinguishing character of this genus consists in the position of its beak, which inclines to the left; but this distinction cannot always be relied upon, as the younger shells are sometimes wholly destitute of any beak, and hence a confusion with many other genera has often taken place.

The greater part of the shells which constitute the first and second divisions, have their outer lip extended either into the form of an expanded wing, (hence called Alate or Winged-shells), or projecting in distinct linear divisions or pointed claws; but these appearances are only manifest in adult shells. The most remarkable of those species which have the lip terminated by claws are the S. chiragra, S. scorpius, S. lambis and S. millepeda. The number of claws in the different species, (with the exception of the S. pes-pelicani, which has only four,) varies from six to ten. In some the claws are nearly straight, and often smooth, while in others they are very much curved, and covered with nodules. The growth of thése shells particularly deserves nofice: it has alrealy bem stated that the very youme 
shells have no appearance of claws; which first present themselves in the form of short and open cainaliculated fissures; when the shells are farther advanced in growth, the claws assume their proper shape, but are thin, hollow, and imperfectly closed; but become filled up and solid, when the shells hare arrived at their full growth. Of the winged class the S. gallus, S. auris-dianæ, S. latissimus and S. gigas have the lip most expanded. The $\mathbf{S}$. luhuanus, and a few others, have some of their whorls very gibbous, and are on that account generally known by the name of Pouters. The colors of the interior are usually extremely vivid and beatiful. The fourth and fifth divisions consist of turreted shclls, the former being distinguished by a longitudinal fissure, extending from the aperture to the summit; and the latter by its lengthened spire, which gives the shells a resemblance to some species of the Murex, and is exemplified in the S. fusus. The S. oniscus, the only shell of the sixth division, is destitute of a winged termination.

The S. latissimus and S. fusus, are two of the most rare species of the genus.

The African, Indian, American, and European oceans produce many species of this genus, and some few are found in the Mediterranean, Red, and Arctic seas.

This genus derives its name from the resemblance which some of its species bear to a whipping-top (бтро́ $\mu$ ○ос).

Drvision I.-Shell with linear segments, or claws, at the margin of the outer lip.

Scientific Name.

Chiragra ........

Scorpius
Localty.

China, Mauritiu Amboyna, China ...... Scorpion .. do .. 
UNIVALVES — STROMBUS.

Scientific Name.

Locality.

Common Name.

Lambis ....... South Seas, Asia, Red Sea Spider Claw-shell

Millepeda ..... China,Ceylon, Coromand. Millepede - do ..

Purpureus ...... .................. Purple mouth do

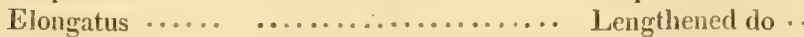

Truncatus ..... East Indies, China .... Truncated . do ..

Pes-Pelicani .... Britaiu, Mediterranean,

Norway .......... Pelican's foot do

Division II.-Shell with the outer lip much expanded.

FAnnLY 1.-With the murgin of the outer lip thickened or lobed.

Gigas ........ West Indies, America .. Giant Wing-shell

Accipiter...... Asiatic Ocean ........ Heavy .... do ..

Gallus........ West Indies ......... Plough .... do ..

Tricornis ...... Ditto, Red Sea ........ Three-horn'd do

Pugilis ....... Ditto, Florida ......... 'Thick-spin'd do ..

Fasciatus ...... Jamaica, Goree ...... Banded ... do ..

Lentiginosus .... Amboyna, China, Mauritius $\ldots . . . . . .$. Pink-lipped do ..

Papilio ....... East Indies ......... Butterfly .. do ..

Auris-Dianæ .... Amboyı, China, Asiatic

Ocean .............. Diana's ear do..

Pacifica ...... South Seas ......... Pacific .... do ..

* Granulatus ... California .......... Cramulated do ..

Polyfesciatus .... Red Rea ........... Many bauded do

Luhuanus ..... South Seas .......... Luhoe ... do ..

Cantrium … . E. Indies, R.Sea, Amboyna Partridge .. do .

Famis 2.-Tith the outer lip curved i moards.

Latissimus ..... Asiatic Ocean, Amboyna,

China .............. Broad-winged do

Laciniatus ..... East Indies ......... Sinuated .. do .. 
FAMrLY S.-Spire elevated, and outer lip rounded and short.

Scientific Name.

Vittatus ...... Asia, China, Red Sea,

Amboyıa ......... Ribbon Strombus

Epidromis .... . Ditto ............. Mainsail .. do ..

Sulcatus ...... China ............ Sulcated .. do ..

FamiL 4.-With both lips pointed, and attuched to the whorls of the spire.

Marginatus .... China ............. Margined - do .. Minimus ....... E.Indies, Amboyna, China Least .... do .. Accinctus ..... Amboyna, Batavia, ditto Girdled ... do ..

Drvision III.-Shell smooth or plaited, outer lip striated within, and but slightly expanded.

Gibberulus ..... Asiatic Ocean, Mauritius,

China............. Pouter .... do ..

Urceus ........ Ditto ............... Pitcher ... do ..

Erythrinus ..... Red Sea ........... Nodulous .. do ..

Samar ......... Amboyna, East Indies .. Samar .... do ..

Dentatus ...... Mauritius ........... Toothed .. do ..

Division IV.-Shell turreted, with a longitudinal fissure extending from the aperture to the summit.

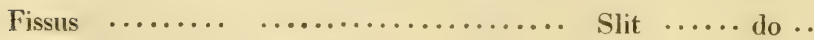

Fissurella ..... East Indies ......... Fissure .... do .. 
Drvisros V.-Shell turreted, with a very long spire.

FamLy 1.-The aperture ending in a long beak, and the outer lip toothed.

Scientific Name.

Fusus

Unicornis
Locality.

Red Sea

East Indies
Common ams.

Spindle Strombus Unicorm ... do ..

FAMiLx 2.-Without the beak and the aperture not toothed.

Tuberculatus.... Mediterranean ....... Tuberculated do Palustris ....... East Indies .......... Marsh .... do .. Ater ......... Marshes in Amboyna .. Black .... do .. Auritus........ Guinea ............ Eared .... do .. Lividus ........................ Livid .... do .. Costatus ....... Britain ............ Ribbed .... do ..

Divisiox VI.-Shell ob-ovate, with transverse nodulous belts, pillar lip granulatcd, and the outer lip thickened and toothed within.

Oniscus....... West Indies ........ Wood-louse do.. 



\title{
MUREX._Rock or Trumpet-Shell.
}

\author{
DESCRIPTION OF PLATE XXVI. \\ Drv. 1. - Fam. 1. Fig. 2. M. tribulus. \\ Drv. III.Fam. 2. Fig. 8. M. rota. \\ DrF. IV. - Fam. 1. Hig. 5. M. rana. \\ Drv. VI.-Fig. 4. M. fimbriatus. \\ Drv. IX-Fam. 1. Fig. 1. M. babylonius. \\ Drv. XII.-Fig. 6. Ml. asper.
}

Shell univalve, spiral, rough, with membranacous sutures; aper.. ture oval, ending in an entire, straight, or slightly ascending canal.

THE most prominent character which distmguishes the species of this genus from those of the two preceriing genera, consists in the beak being almost invariably straight, and very much produced, sometimes turning a little upwards.

The Murices are shells of irregular form, arising from their surfaces being usually armed with spines, knobs, striae, or foliations. The shells of the first division have the beak considerably produced, and are distinguished from those of the second by the spines with which their surfaces are armed; the most remarkable species is the M. tribulus, of which there are two varieties; (the more common being called the Thorny-Woodcock, and the rarer Venus's Comb;) the latter is one of the most elegant shells of the genus. When perfect its exierior is most beautifully adorned with regular rows of thin and delicate spines.

K 2 
The next division comprises those species which are commonly known by the name of Triplices, or more properly Purpuræ, as the animals inhabiting most of the shells of this class produce a liquid of a rich purple color, hence the whole genus has by some authors been called Purpura: the species are foliated, and have a much shorter beak than those of the preceding. The sutures are composed of crisped foliations, and acute angular ramifications, which are most strikingly marked in the M. radix, and the pink and yellow mouthed varieties of the M. saxatilis. The number of rows in these sutures differs considerably, some, as the M. ramosus, \&c. have but three, the M. scorpio has four, and the M. saxatilis five.

The fourth division is composed of those species that have their sutures thick, protuberant, and rounded; such are the M. rain, M. femorale (or Gadroon-whelk) and M. lyratus. The fifth division consists of only two species, which are of irregular form.

In the species of the sixth division, the form is more abbreviated and gibbous, they are also more or less spinous, and withont a manifest beak: as the M. ricinus, M. hippocastanum, M. neritoideus.

The ninth division is composed of such shells as have a long, straight, subulate, closed beak, and unarmed with spines. The M. babylonius, and others of the first fanily, have a sinall fissure or incision on the extremity of the outer lip, close to the termination of the first whorl, a peculiarity solely confined to these species. 
In the tenth division the spire is rather depressed, and the beak so much shortened, that in some of the species, and particularly in the $\mathrm{M}$. ficus, a resemblance to the Bulla ficus may be observed.

The eleventh division is composed of the species which have a ventricose and oblong form, with a dilated aperture: the most remarkable is the M. tritonis which is used by the natives of New Zealand, and by the Africans and many nations of the East, as a horn or trumpet; it sometimes exceeds two feet in length.

The last division of the Murices includes those species that are tapering and subulate, having a very short beak: among them may be noticed, the M. vertagus and M. aluco.

Of the rarer species may be enumerated the M. perversus, M. prismaticus, M. stramineus, M. radix, M. aruanus, M. regius, M. pinata, \&c.

The numerous species of the Murex are found in the European, Northern, and Southern Seas; India, and in the Mediterranean, Adriatic, and Atlantic.

This genus derives its name from many of its species heing rough, like the sharp crags of a rock (Murex).

\section{Drvision I.-Shell spinous with a produced beak.}

Fanicy 1.-With three varices.

Scientific Name.

Tribulus a...

Scolopax ........

Motacilla .......

\section{Locality.}

Asiatic Ocean ......... Thorny Woodcock

Red Sea ............ Thorny Snipe M.

East Indian Seas ...... Nightingale do.. 
FAmLY 2.-With seven varices.

Scientific Name.

Cornutus ........

Brandaris
Locality.

Africa, Amboyna ...... Horned Snipe M.

Guinea........ Short beak'd Snipe

Drvisron II.-Shell with a produced beak similar to the first division, but not spinous.

Haustellum .... Asiatic Ocean, Red Sea,

China........ Snipe... do ..

Spirillus ....... Tranquebar, Malabar .. Blunt tipped do ..

Drvision III.-Shell foliated, with a short beak.

Famry 1:-With three varices.
Ramosus...... S. Seas, E. \& W. Indies,
Amboyna ............. Branched .. do ..
Foliatus ...... New Zealand ......... Foliated . . do ..
Lingua ...... Goree ............ Sheep's tongue do
Tripterus ...... Batavia ........... Subtriangular do
riqueter...... Tranquebar, China .... Three warted do

FAMILY 2,-With more than three varices.

Scorpio ...... Amboyna, China ..... Scorpion .. do ..

* Rota ........ Red Sea ........... Wheel ... do ..

Saxatilis ....... Mediterranean, Guinea,

Asiatic Ocean ....... Endive ... do ..

Trunculus ...... Mediterranean ........ Tyrian dye do ..

Rosarium ...................... Rosary ... do ..

Pomum ....... Mediterrauean, Senegal - Appleshap'd do..

Miliaris ....... Nicobar Isles ......... Scabrous .. do ..

Radix ......... Peru ............. Root ...... do.. 
UNIVALVES _ MUREX.

135

Seientific Name.

Locality.

Common Name.

Melanomathos .. East Indian Seas ...... Black-spined M.

Lamellosus .... Straits of Magellan .... Lamellar .. do ..

Clathratus ..... Iceland, Norway ...... Ribbed ... do ..

Erinaceus ..... Britain, Mediterranean .. Rough ridg'd do

Scala ........ East Indies ......... Ladder ... do ..

Drvision IV.-Shell with thick protuberant rounded varices.

FamiLY 1.-With two opposite varices.

Rana........ Africa, China, Amboyua Frog .... do..

Crassus ....... Madagascar.......... Thick frog do..

Spinosus...... Tranquebar.......... Spiny frog do ..

Gyrinus ....... Scotland, Mediterranean, India .............. Whorled .. do ..

Bufonius ....... South Seas ........ . Toad shap'd do ..

Lampas ....... Mediterranean, Madagascar, East Indies ..... Granulated do ..

Scrobilator .... Mediterranean, Senegal - Violet throated do Reticularis ..... Carolina, West Indies,

Mediterranean .....: Reticulated do :-

FAMILY 2.-With twa subalternate varices.

Argus......... Amboyna, Mediterranean Argus .... do ..

Olearium ...... Africa, Mediterranean,

South of Europe .... Oil jar ... do ..

Rubecula ...... Red Sea ............ Footman .. do ..

Femorale ..... Guinea, E. \& W. Indies : Triangular do ..

Lotorium ..... Jamaica, Amboyna .... Angulated do ..

Pileare ....... Mediterranean ........ Nodulous . do ..

Candisatus ..... .................. Mottled .. do ..

Maculosus ..... Amboyna, Mauritius .... Spotted ... do ..

Spengleri ..... New South Wales...... Spengler's . do ..

Pyrum ........ Coromandel ......... Pear .... do ..

Clavator....... Ceylon ............. Club shap'd do ..

Caudatus ...... Coromandel ......... Caudated . do ..

Dolarium ...... Portugal ........... Narrow belt do .. 
Family 3.-With a single varix.

Scientific Name.

Parthenopus ....

Cutaceus . .....

Clandestinus ....

Lyratus
Locality.

Bay of Naples ...

Africa, W. Indies, Corom

.....................

New Zealand .
Common Name:

Tawny yellow M.

Rough skin do.. Double lipp'd do Lyre shap'd do..

Division V.-Shell with unequally gibbous whorls, decussated ribs, and the aperture surrounded by a thin dilated membrane.

Anus......... As. Ocean, Mediterranean Grimace Whelk

Mulus........ Coasts of Hitoe ....... Mule .... do ..

Division VI.-Shell somewhat spinous and without a beak.

Ricinus ........ Asiatic Ocean, China ... Spur..... do ..

Nodus........ Jamaica ............ Chesnut .. do ..

Neritoideus .... Guinea, South Seas.... Mulberry . do ..

Fimbriatus ....................... Seal-skin .. do ..

Hystrix....... E. Indies, ditto ....... Porcupine - do ..

Mancinella..... Amboyna, Madagascar . Mancinella do ..

Hippocastanum . Batavia, Banda........ Horse chesnut do

Sacellum ...... Nicobar Isles ........ Corded ... do ..

Nodatus ....... New Holland ......... Knobbed.. do ..

Lacerus ....... Guinea ............. Carinated . do ..

Virgatus ....... East Indies ............ Nodulous .. do ..

Columbarium .. South Seas ........... White belted do

Senticosus ..... China, South Seas ..... Cancellated do ..

Drvision VII.-Shell nodulous or longitudinally plaited, with a short beak.

Plicatus ....... East Indies ......... Plaited ... do... 
UNIVALVES MUREX.

Scientific Name.

Morbosus......

Consul .........

Undatus........

Fiscellum .......

Dubius .........

Fenestratus
Locality.

West Indies ...........

Fast Indies

Tranquebar............

Pulo Condore ..........

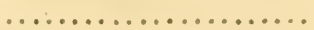

Amboyna .............
Common Name.

Diseased Whelk

Ventricose do..

Waved ... do ..

Short beak'd do

Doubtful .. do ..

Latticed .. do . .

Drvision VIII.-Shell ovate, aperture wide, inner lip thichened and spread, outer lip thich and undulated.

Stramineus .... New Zealand ......... Straw-color'd do Australis...... South Seas ......... Southern .. do ..

Division IX. - Shell with a long, straight, subulate beak, unarmed.

FamiLY 1.-Turreted, outer lip having a notch at the summit.

Babylonius .... Asia, Amboyna, China .. Tower of Babel M. Clavatulus ...... Guinea ............. Crowned tower do Gibbosus...... Red Sea........... Gibbous ... do .. Virgineus ..... Guinea ............. Virgin tower do .. Javanus ....... Java, Tranquebar, China Javanese .. do .. Tornatus ...... Tranquebar, Magellan . White tower do..

Famux 2:-With the column plaited.

Tulipa........ West Indies, South Seas . Tulip .... do .. Nassa ........ West Indies.......... Rough .... do .. Amplustre ..... America, South Seas ... American flag do Trapezium ..... R. Sea, Amboyna, China Striped tower do Polygonus ..... Isle of Frauce, B. of Naples Many angled do Infundibulum ... West Indies .......... Funnel shap'd do Lancea ........ Amboyna............ Lanceolate do .. Ocellatus ...... West Indies......... Eyed .... do .. Craticulatus .... Mediterranean ........ Plaited ... do .. 
Family S.-With the outer lip entire, and the columin smooth.

Scientific Name.

Colus

Striatulus ......

Versicolor... .

Verrucosus .....

Aruanus

Tuba

Canaliculatus ...

Carica...... .

Perversus .......

Ternatanus......

Pardalis

Maroccensis ....

Cariosus ........

\section{Locality.}

Amboyna........... Spindle M.

.................. Transversely str.

East Indian Seas ....... Changeable do ..

Red Sea ............. Warty .... do ..

China, Isle of Aru, Africa Aru Trumpet do

China ............. Trumpet .. do ..

Canada, Virginia ...... Channelled do .. ................... Keeled ... do ..

Mexico,Jamaica, N.Amer. Reversed .. do .. lsland of Ternate ....... Ternate .. do .. .................. Leopard .. do ..

Morocco ............. Morocco .. do .. .................. Carious ... do ..

Drvisron X.-Shell with the spire rather depressed, aperture dilated, nearly the length of the shell, and beak short.

Melongena..... America, Amboyna, Jamaica ............. Open mouth do ..

Calcaratus ..... Amboyna, China ..... Brownish white

Ficus ........ Red Sea........... Fig shaped do ..

Spadiceum ..... West Indies......... Lineated .. do ..

Umbilicatum .... Red Sea........... Umbilicated do ..

Candidum ...... Red Sea ............. White.... do ..

Corona ........ Gulf of Mexico ....... Crowned .. do ..

Morio ......... Africa,W.Indies, Magellan Moor..... do ..

Pugilinus ........ Tranquebar, Moluccas ... Reddish brown do

Cochlidium .... East Indies ........... Brown streaked .

Harpa ....... .................... Harp.... do .. 
Drvision XI.-Shell oblong, ventricose, aperture dilated and ovate, spire produced and beak short.

Scientific Name.

Antiquus ...... Norway, Britain,Denmark

Magellanicus....

Norwegicus... .

Fornicatus ......

Despectus ......

Subantiquatus ..

Tritonis ........

Nerei .........

Vulpinus ........

Pusio

Corneus ........

Lineatus ......

Lignarius .....

Syracusanus ....

Perron .........

Prismaticus .....

Bamffius ........

Gracilis ........

Attenuatus......

Nebula ........

Costatus........

Proximus .......

Septangularis ...

Turricula .......

Rufus .........

Sinuosus ........

Linearis ........

Purpureus ......

Muricatus ......

Minutissimus ...

Arenosus .......

Scriptus .......

\section{Locality.}

Straits of Magellan .....

Nórway ...............

Greenland $. . . \ldots \ldots . .$.

Northern Ocean, lceland

Britain ...............

Mediterranean, Amboyna,

America .......... Triton .... do ..

South Seas........... Musical ... do ..

.................. Fox ..... do ..

Mediterranean ........ Wreath ... do ..

Gt. Britain, S. of Europe Slender horn do ..

New Zealand ......... Lined .... do ..

Southern Europe ....... Woody .... do ..

Mediterranean ......... Syracuse .. do ..

South Seas ........... Shelving ... do ..

Ditto, Pulo Condore .... Prismatic .. do ..

Scotland, England ..... Bamff .... do ..

Britain ............. Elegant ... do ..

West of England ....... Lengthened do ..

Britain .............. Clouded .. do ..

Ditto, Norway ......... Ribbed ... do ..

Scotland ............ Many ribbed do .

West of England ...... Seven sided do ..

Britain ............. Turreted .. do ..

Ditto ................ Red ... do

Weymouth ........... Sinuated .. do ..

West of England ...... Lineated .. do ..

Devonshire ........... Purple .... do ..

Ditto ................ Thorny.... do ..

Pembrokeshire ......... Very small do ..

India .............. Sea sand .. do ..

Mediterranean ....... Written .. do .. 
Division XII.-Turreted and subulate, with a very short beak.

Scientific Name.

Obeliscus

Vertagus..... .

Plicatulus.....

Aluco...... .6 .

Tuberosus $\ldots .$. .

Adausoni.....

Clava

Uncinatus $\ldots . .$.

Atratus .......

Alucoides ......

Ebeninus .......

Fuscatus ........

Torulosus .......

Radula

Marginatus .....

Serratus ......

Asper .........

Granulatus ....

Sulcatus ........

Literatus ......

Hexagonus......

Reticulatus......

Tubercularis ....

Adversus ......

Subulatus ......

Decollatus ......
Locality.

West Indies

Amboyna, East Indies .. Curved beak do .

East Indies .......... White plaited do

Mediterranean, Amboyna Caterpillar do ..

Amboyna, Red Sea ....

River Gambia ..........

Pulo Condore ..........

..................

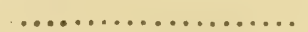

Mediterranean, Adriatic .

South Seas ...........

Mediterranean, Senegal .

East Indies ...........

Africa, West Indies .....

East Indies .......... Margined . do ..

New Zealand ......... Serrated .. do ..

West Indies ........ Rough grain'd do

Asiatic Ocean ........ Grained ... do ..

Marshes in Moluccas ... Grooved .. do ..

Guadaloupe ......... Lettered .. do ..

South Seas .......... Six ribbed . do ..

Britain ............. Reticulated do ..

Ditto.............. Tuberculated do .

Ditto ............... Left banded do ..

Scotland...$\ldots \ldots \ldots$. Awl shap'd do ..

Decapitated do .. 


\section{TROCHUS. - TOP-SHELL.}

\section{DESCRIPTion OF PLATE XXVir.}

Drv. 1.- Fam. 1. Fig. 5. T. concarus.

Fam. 1. Fig. 1. T. solaris.

Dr. II.-Fam. 1. Fig. 4. T. cookii.

Fam. 1. Fig. 2. T. iris.

Drv. III. - Fam. 1. Fig. 3. T. telescopium.

Shell univalve, spiral, more or less conic; aperture somewhat angular or rounded; the upper side transverse and contracted; pillar placed obliquely.

THE leading characteristic of the Trochus is the conical shape of its species, the base being broad and the whorls gradually tapering towards the apex. This form prevails with very few exceptions throughout the genus; some, however, have so strong a resemblance to the Turbo, that ifrequent mistakes have been made in their classification.

A fow species of this genus lave their surfaces almost smooth; but the greater number are covered with knobs, spines, tuberculations, or undulations, of which the $\mathbf{T}$. solaris and the T. imperialis are striking examples. The former has its margin beset with long spines, placed at regular distances, and, when the shell is perfect, re sembling the rays of the sum, as represented in carved work. Many, when uncoated, present a brilliant motherof-pearl appearance; others have only a pearly aperture, and a few oxhibit a bronze-like hue. The aper- 
ture of the shell in this as well as in many other genera of univalves, is closed by a stony or horn-like operculum, affixed to the animal.

Of the divisions of the Trochus the first is the most numerous; it comprehends those species which have their pillar perforated, and is divided into five families, distinguished by the peculiarities of the pillar and umbilicus: the T. niloticus, T. maculatus, T. pharaonis, T. cylindraceus, and T. perspectivus, may be mentioned as illustrative examples of each family.

The T. conchyliophorus, or Carrier Trochus, is a very remarkable species; it is invariably covered with extraneous substances, strongly adhering to the whorls of the shell. There are two distinct varieties: one of which is familiarly called the Conchologist, from its being loaded with perfect shells or fragments; and the second, the Mineralogist, as its adhesions consist of stones, ores, \&c. When the former variety is loaded with corals only, it is called the Zoologist or Coralcarrier.

The second division consists of those Trochi which are imperforated, or have their umbilicus closed, as in the T. tuber, (which greatly resembles a Turbo) T. labio, and $T$. vestiarius. The $T$. iris of this division deserves particular notice, on account of the iridescence and splendid metallic lustre which its surface exhibits when uncoated.

The thind division includes those species which are much elongated, and greatly resemble screw or needle shells. Unlike the rest of the genus, they have an exserted pillar; and, when placed on their base, they fall 
on one side. The most prominent species are the $\mathbf{T}$. telescopium and the T. dolabratus.

The T. conchyliophorus, T. imperialis, T. solaris, T. perspectivus, \&c. are highly valued for their beauty and rarity.

The Trochus derives its name from the resemblance

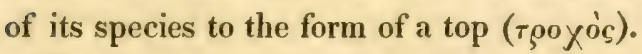

The Trochi are found in almost every part of the world.

Drvision 1.-Shell umbilicated, erect.

FAmixy 1.--With the pillar and umbilicus smooth.

Scientific Name.

Niloticus ........ Ind. Ocean, China, S. Seas

Conus ......... East Indies, New Guinea

Spinosus ....... New Zealand .........

Jujubinus...... Mauritius, West Indies..

Concavus ....... Coromandel, N. Zealand

Vernalis ....... East Indies ..........

Conspersus .... East Indian Ocean .....

Ochroleucus .... Ditto ..............

Stellatus....... Ditto ..............

Spengleri $. . . \ldots . . . \ldots \ldots \ldots \ldots \ldots$

Costatus ........

Inæqualis .......

Regius .........

Verrucosus ......

Radiatus ........

Viridis........ New Zealand .........

Fanulum ...... Pernambucca ........

Strigosus ....... Moroceo .............

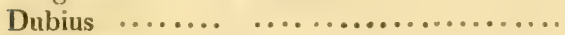

Depressus ......

Lavis ........

Groenlandicus .. Norway, Greenland ....

Magus .........
Common Name.

Large marble ' $\mathrm{T}$.

Conic ... do ..

Thorny ... do ..

Mottled .. do ..

Concave .. do ..

Green .... do ..

Poppy .... do ..

Whitish brown

Starred ... do ..

Spengler's - do ..

Ribbed.... do ..

Unequal .. do ..

Royal .... do ..

Warty .... do ..

Radiated .. do ..

Green .... do ..

Pagoda ... do..

Black lipp'd do ..

Doubtful .. do ..

Depressed - do ..

Smooth ... do ..

Grcenland do..

Tuberculated do . 
Scientific Name.

Variegatus ......

Afer ..........

Muricatus ......

Roseus .........

Patholatus ......

Scaber..........

Quadratus ......

Croceus ........

Varius..........

Obliquatus ......

Cinerarius ......

Neritoideus .....

Albidus .........

Vittatus ........

Divaricatus .....

Fuscatus .......

Umbilicaris .....

Cinereus........

Fasciatus........

Planus.........

Solaris ........

Inermis ........

Imperialis ......

Conchyliophorus

Tectum .........

Pumilio ........

Terrestris .......

Bidens

Fragilis

Carinatus ......

Flumineus ......
Locality.

Cape of Good Hope ...

Cape Dakar in Senegal . .

Mediterranean .......

C. of Good Hope, Naples

West of England .......

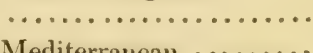

Morocco..............

Mediterranean .........

Ditto, Britain ........

West Indies, Norway,

Mediterranean .......

Greenland ............

...................

Mediterranean, Norway

...................

Mediterraneau .........

Ditto

.....................

..................

East \& West Indies, India,

South Seas .........

West Indies ...........

New Zealand .........

St. Domingo, China ....

West Indies, Mauritius .

Africa .............

Britain, Italy, Tunis ....

Botannic Garden, Strasburgh ............ ....................

Saxe Weimar .........

River Huines ..........
Common Name

Variegated T. ..

Grey marble do . Prickly ... do ..

Rose-color'd do.. Tumid ... do .. Rough .... do .. Square spotted do Saffron color'd do Varied .... do .. Umbilicated do ..

Ashy color'd do. Reddish color'd do White .... do .. Ribbon ... do .. Divaricated do .. Brown .... do .. Obliquely rayed Cinereous - do .. Banded ... do .. Flat ..... do ..

Sun ...... do .. Short-spined do .. Imperial .. do .. Carrier.... do .. Arch-lipp'd do .. Dwarf .... do .. Land .... do ..

Double-tooth'd do Brittle .... do .. Keeled .... do .. River.... do..

Family 2.-With pillar toothed or plaited, and umbilicus smootí.

Maculatus

Madagascar Spotted ... do . Alveare ....... Mauritius .......... Bee-live .. do . 
UNIVAIVES_TROCHUS.

Scientific Name.

Tentorium ......

Agrestis

Niger

Cruciatus $\ldots . .$. .

Modulus ........

Declivis ....... Red Sea ............

Viridulus .......

Perlatus

Locality.
.................. Pavilion Trochus

China ............. Rustic .... do ..

Ditto............... Black .... do ..

Mediterranean ........ Cross-rayed do ..

West Indies, Red Sea ... Keel-swhorl'd do .

Red Sca ........... Egyptian .. do ..

................. Necklace-grained

.................... Pearly $\ldots$... do..

Family 3.-With pillar smootih, and moilicus tooithed or cronated.

Cylindraceus ....

Carneus .........

Areola .........
Sub-conical do .. Flesh-color'd do . . Red square-spotted

FAMILY 4.-With pillar and umbilicus crenated.

Pharaonis..... Red Sea, Mediterranean,

East Indies ........ Strawberry do ..

Corallinus ..... Magdalen Isles........ Coral bead. do ..

Guineensis..... Guinea ............. Guinea.... do ..

Urbanus ....................... Purple-striped do

Famux 5.-Shell depressed, with the unbilions large, pervious, and crenated, in which the conrse of the whorls is strongly marked.

Perspectivus .... Amboyna............ Staircase .. do ..

Perspectiviunculus ................. Small staircase do

Infundibuliformis $\ldots \ldots \ldots \ldots \ldots \ldots \ldots$............. Funnel-formed do

Hybridus ...... Mediterranean ........ Mongrel .. do ..

Stramineus...... Tranquebar........... Straw-color'd do

Indicus ....... East Indies ......... Indian ... do .. 
Drvision II.-Shell imperforate, erect.

Fanis 1.-With the pillar smooth.

Scientific Name.

Grandinatus ....

Tuber

Melanastomus ...

Striatus ........

Minutus ........

Punctulatus .....

Conulus ........

Zizyphinus......

Papillosus

* Undatus

Granatum .....

Virgineus ......

Diaplıanus ......

Selectus ........

Purpurascens....

Imbricatus ......

Cælatus.........

Gibberosus .....

Virgatus . ......

Cookii ...........

Iris ............

Elegans ........

Notatus .......

Ziczac .........

Obtusus ........

Crocatus........

Hortensis .......
Locality.

South Seas

Mediterranean, W. Indies

Southern Ocean ........

Mediterranean, Britain .

Britain, France, Morocco

W. Ind., France, Morocco

Mediterrancan ........

Ditto, Britain, Red Eea.

Britain, Mediterranean, E.

Indies ............

California ............

New Zealand .........

Magellan, New Zealand.

New Zealand ..........

Ditto ...............

................... so...

West Indies ...........

Ditto ................

New Zealand .........

East Indies, Amboyna ..

New Zealand ..........

Ditto ................

Ditto ...............

South Seas ...........

Britain, West Indies ....

East Indies

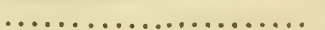

Southern Climates......
Common Name.

Studded Trochus

Large mottled do

Black throated do

Striated ... do ..

Crimson tip do..

Rose-color'd do...

Conical ... do ..

Livid ..... do ..

Granulated do .. Undulated - do ..

Tiger .... do ..

Ringed .... do ..

Thin ...... do ..

Red \& white do ..

Purple.... do .. Imbricated do .. Scaly .... do .. Olive-green do .. Rose-striped do .. Cook's .... do ... Iris ....... do .. Elegant ... do .. Marked ... do .. Ziczac .... do .. Blunt .... do do. Saffron color'd do Garden ... do ..

Family 2.--With the pillar toothed.

Labeo ......... Amboyna, South Seas .. Double-lipp'd do

Asper ........ New Zealand ........ Rugged ... do ..

Quadricarinatus . Mediterranean ....... Four-keeled do .. 
UNIVALVES-TROCHUS.

Scientific Name.

Tessellatus .....

Turbinatus......

Argyrostomus ...

Merula ........

Crassus .........

Americanus ....
Locality.

St. Croix, Naples ...... Tessellated Troch

Mauritius, Mediterranean 'Turbinated do ..

New Zealand, Arabia... Silver-mouth'd do

China, South Seas..... Chinese ... do ..

Britain ............. Heavy .... do ..

America ............ American . do ..

Family 3.-With the pillar twisted.

Mauritianus..... Mauritiıs, New Guinea - Great-tooth'd do

Fenestratus..... Amboyna, Frederick's 1sl. Small-tooth'd do

Pyramis ....... South Seas, East Indies.. Obelisk ... do ..

Dentatus ...... Red Sea, Guinea ...... Sugar-loaf - do ..

FaniLy 4.-Shell convex, smooth, with a thich vitreous matter which covers the centre of the base,

Vestiarius....... Mediterranean, Cape of

Good Hope, India ... Flattened .. do ..

Division III.-Shell tapering, with the pillar exserted, and the shell falling to one side whenplaced upon its base.

Famiry 1.-With pillar twisted.

Telescopium .... East Indies .......... Telescope - do .. Terebellus ..... West Indies ......... Little augur do..

Dolabratus..... Africa.................. Zebra... do ..

FamiLy 2.-Pillar straight.

Minute Shells.

Punctatus...... Mediterranean ........ Dotted .... do .. Striatellus ..................... Violet lipp'd do ..

L. 2 
Reversed Shells.

Scientific Name. Locality. Common Name.

Perversus...... Mediterranean ........ Reversed Trochus

Pusillus ...... East Indies .......... Minute ... do ..

Undulatus ..... Ditto.............. Waved ... do ..

Ventricosus ..... Ditto .............. Bellied ... do ..

Annulatus ..... Ditto................ Annulated . do ..

Lunaris ......................... Horn-color'd do.. 


\section{TURBO. - Wreath, or Turban-Shell.}

\section{DESCRIPTION OF PLATE XXVIII.}

Drv. II.-Fam. 6. Fig. 1. T. chrysostomus.

Drv. III. Fam.2. Fig. 5. T. muricatus. Div. V. Fam. 1. Fig. 2. T. scalaris. Div. IV. Fig. 4. T. delphinus.

Drv. IX. Fig. 3. T, archimedis.

Shell univalve, spiral, solid; aperture contracted, orbicular, entire.

THE greater number of the shells of this beautiful genus are solid and ponderous, and many, when decorticated, exhibit splendid iridescent colors. They are distinguished from the Trochi by the suborbicular form of the aperture.

The first division las the pillar margin of the aperture dilated, and the pillar imperforate. Among the leading species may be mentioned the T. obtusatus, $\mathbf{T}$. neritoideus, and T. littoreus, or common Periwinkle.

The next division comprises the solid and imperforated species, of which the most characteristic are the $T$. petholatus, T. smaragdus, T. chrysostomus, T. pagodus, and T. calcar. The T. marmoratus and T. olearius sometimes attain a considerable size.

The third division differs from the preceding, in having the pillar perforated or umbilicated: the T. pica being a common shell, and well known, may be referred to as strikingly illustrating the character of this 
class: the T. margaritaceus and $\mathbf{T}$. argyrostomus are remarkable for the delicate coloring of their mouths.

The T. delphinus may be adduced as an example of the species of the fourth division.

The fifth division contains some of the most beautiful species of the genus: they are in general thin and transparent, and strongly marked by rows of elevated continuous ribs. The T. scalaris (the True Wentle-trap *), on account of its beauty and rarity, deserves a particular description. The shape of the shell (which is extremely elegant) is a spiral cone, formed by gibbous whorls, gradually decreasing from the base to the apex, unconnected by a columella; this circumstance, so completely opposed to the regular structure of other turbinated shells, bas occasioned considerable doubt as to its classification, and some authors have even placed it among the Serpulæ. The whorls are divided, at regular distances, by rows of elevated, suboblique, longitudinal ribs, which in young shells have a semipellucid appearance. The color is usually a yellowish or brownish white. The T. clathrus, or False Wentletrap, is a very common shell, and much more taper and elongated than the T. scalaris. It has no umbilicus, and the whorls are closely united.

The sixth division greatly resembles the preceding in form, and is only distinguished by its whorls not being surmounted with elevated cancellations.

* Wentle-trap is derived from a German word, Windle-treppe, signifying a winding stair-case. 
The shells of the seventh division are celebrated for the beauty and variety of their coloring; the T. phasianus in particular, has its colors disposed in resemblance of the plumage of the Pheasant.

A considerable variation in form characterizes the eighth division; the shells being obtuse at both ends.

The similarity which exists between the shells of the ninth division and those of the corresponding class in the Strombus and Buccinum, is strikingly observable in the T. imbricatus, T. replicatus, T. acutangulus, T. duplicatus, and T. terebra; but the circular form of the mouth distinguishes them from the turreted species of the other two genera: their shape is that of a well proportioned spire, with thirty or forty whorls gradually diminishing, and terminating in a very acute point.

The last division contains the depressed species, of which may be particularised the $T$. nautileus: this shell is often found affixed to plants in stagnant waters.

Among the rare and beautiful species of the Turbines the T. scalaris and T. phasianus are the most conspicuous. The value of the $\mathbf{T}$. scalaris depends upon its size and perfection, choice specimens having been sold for

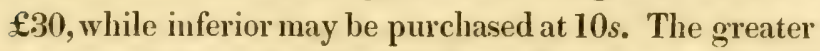
number of those species which are found in the South Seas are extremely rare.

The generic name, Turbo, is derived from the Latin, and has the same signification with the Greek derivative of the preceding genus. 
The American, African and Indian Oceans, produce the greater number of species; a few only are found in the Mediterranean, European, and Northern Seas.

\section{Division I.-Shell imperforate, and the pillar lip fat.}

FAMiLY 1.-With a smooth exterior.

Scientific Name.

Obtusatus .....

Neritoides ...... Mediterranean ....... Nerite shaped do .

Nicobaricus .... Nicobar Isles .......... Nicobar ... do ..

Nigerrimus .... New Zealand ......... Black .... do ..

Rudis ........ Norway, Britain ....... Sordid .... do ..

Punctatus....... Goree ............... Punctured . do ..

Petræus ....... Dorset, Devon ......... Small rock do .. Fulgidus ........ Pembroke, Cornwall ... Bronze-bauded do

FAMLY 2.-With the exterior striated or ribbed.

Littoreus....... Britain, Norway ....... Periwinkle ...... Tenebrosus ..... England .............. Chocolate . do .. Crassior....... Ditto............... Coarse ... do .. Jugos!s........ Ditto............... Lineated .. do .. Ethios: ....... New Zealand ......... Black \& white do

Division 11.-Shell imperforate, solid.

FAMILY 1.-With a smooth exterior.

Personatus ....................... Convex ... do.. Petholatus ..... Amboyna, Mauritius ... Serpent's skin do Cidaris ........ Moluceas........... Turban .... do .. Helicinus ...... ................... Green \& purple Imperialis ..... China ............. Imperial ... do .. 
FamiLy 2.-With the exterior striated.

Scientific Name.

Locality.

Cimex

Calathiscus

Cochlus ....... Mauritius, Asia, China ..

Smaragdus...... New Zealand
Common Name.

Bug Turbo ....

Cancellated do ..

Cameleopard do .

Green ... do ..

FAnm 3.-With the exterior granulated.

Castaneus ..... West Indies.......... Chesnut ... do .. Crenulatus...................... Crenulated do..

Papyraceus .... East Indies ........... Paper..... do ..

\section{FAMILY 4.-With the exterior nodulous.}

Trochiformis .... Southern Ocean ....... White grain'd do Marmoratus .... Asiatic Ocean, China ... Marbled .. do .. Sarmaticus...... Moluccas, C. of G. Hope Large knobbed Olearius ....... India, Coromandel ..... Large keeled do . Coronatus ..... Moluccas, Nicobar Isles.. Coronated . do ..

\section{FAMILY 5.- With the exterior ribbed or grooved.}

Canaliculatus ... Moluccas, Philippines .. Grooved . do .. Setosus ........ Mauritius ........... Leopard ... do .. Sparverius ..... East Indies .......... Pearly mouth'd do Spenglerianus .. Ditto............... Spengler's . do ..

FAmix 6.-With the exterior somewhat spinous.

Chrysostomus .. S.Seas, R. Sea, Amboyna Golden-mouth'd Tectum-persicum Asiatic Ocean ......... Little pagoda do. Pagodus ....... Ditto, Amboyna....... Pagoda.... do .. Calcar ........ Amboyna, China ..... Spur .... do .. Stellaris ...... South Seas ......... Starred ... do 
Scientific Name.

Aculeatus ......

Stellatus ........

Armatus ........

Rugosus ........

Cornutus .......

Radiatus ........

Moltkianus
Locality.

Nicobar Isles

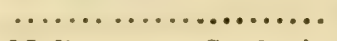

Mediterranean, Scotland.

East \& West Indies .....

China

Red Sea ............
Common Name.

Painted Turbo ..

Spined .... do .. Armed ... do .. Rugged ... do .. Large-horned do Radiated .. do .. Moltkian's - do ..

\section{Minute Shells.}

Semicostatus .... Devon, Scotland ..... Ribbed .... do .. Ruber ......... Pembroke, Cornwall ... Red ..... do .. Vitreus ....... Cornwall ........... Glassy .... do .. Punctura ...... West of England ..... Punctured . do .. Arenarius ...... Salcomb Bay ........ Sand ..... do .. Unifasciatus .... Britain ............ Banded ... do ..

Nivosus ...... Devonshire ......... White .... do ..

Labiosus ...... Britain ............. Lipped ... do .. Ulvæ........ Ditto.............. Sea-weed .. do .. Ventrosus ..... Ditto.............. Bellied .... do ..

Subumbilicatus.. Weymouth .......... Yellow .... do .. Cingillus ...... Britain ............ Girdled ... do .. Interruptus ..... England \& Wales..... Streaked .. do .. Semistriatus .... Devonshire ........... Semi-striated do. Albulus ....... Greenland Seas ....... Pellucid ... do ..

\section{Division III.-Shell umbilicated and solid.}

FAMILY 1.-With the umbilicus toothed.

Pica.......... West Indies, Sardinia .. Magpie .. do ..

Nodulosus ..... Ditto ............. Nodulous .. do .. 
Family 2.- The umbilicus vothout teeth.

\section{Scientific Name.}

Dentatus

Muricatus .......

Auricularis .....

Vinctus

Quadrifasciatus..

Sanguineus .....

Atratus ..........

Anguis ........

Diadema ........

Undulatus ......

Argyrostomus ...

Margaritaceus...

Porphyrites .....

Mespilus .......

Granulatus .....

Cinereus .......

Torquatus
Locality.

.................. Toothed Turbo ...

Southern Europe ...... Prickly .... do ..

Southampton ......... Eared.... do ..

Devonshire ........... Brown banded do

Cornwall, Swansea .... Four banded do ..

Mediterranean, Algiers . Scarlet .... do ..

Nicobar Isles ......... Black grained do

Sonth Seas .. ........ Snake .... do ..

New Zealand ......... Diadem ... do ..

Van Dieman's Laud, New

Holland .......... Waved ... do ..

Indian Ocean, Red Sea,

Cape of Good Hope - Silver mouth do

Frederick's Island ...... Pearly .... do ..

New Caledonia ........ Porphyry .. do ..

South Seas .......... Medlar ... do ..

Ditto, Nicobar Isles .... Granulated do ..

..................... Aslu-color'd do ..

New $/$ ealand....... Thready.. do ..

Drvision IV.-Shell depressed, foliated, spinous or nodulous, and umbilicus large, pervious, and armed within.

Delphinus ..... Asiatic Ocean, Mauritius,

Amboyna ........... Dolphin .. do ..

Exasperatus .... East Indies .......... Granulated do ..

Distortus ...................... Distorted .. do .. 
Division V.-Cancellated.

FamiLy 1.-Umbilicated.

Scientific Name.

Scalaris........

\section{Locality.}

Clina
Common Name.

Wentle-Trap ...

\section{FamuY 2.-Imperforated.}

Principalis ..... Coromandel .......... Many-ribbed do . Clathrus ...... Europe, America ...... Latticed .. do .. Clathratulus .... Britain ............ Little .... do .. Lacteus ...... Mediterranean ....... Milky .... do .. Pulcher ....... West Indies.......... Beautiful .. do .. Ambiguus ..... Mediterranean ........ Doubtful .. do ..

\section{Minute Shells.}

Elegantissimus ..

Simillimus ......

Parvus.......

Striatulus ........

Reticulatus......

Bryereus .......

Britain

Elegant Turbo .. Island of Jura ........ Similar ... do .. Britain ............. Guernsey .. do .. Mediterranean, England. Wrinkled . do .. Pembroke, Kent ...... Netted .... do .. Coniferus ...... Weymouth .......... Marginated do .. Denticulatus .... Ditto .............. Toothed ... do .. Arcuatus ...... Guernsey ........... Margined.. do ..

Striatus........ Cornwall, Devonshire, Ireland ........... Striated.... do ..

Costatus ...... England, Wales...... Ribbed ... do . Unicus ....... Sandwich .......... Convex ... do ..

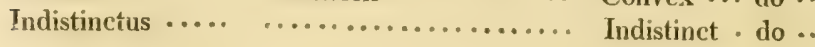


Drvisron VI.-Shell with subcylindrieal whorls, similar to the last division, but not cancellated.

\section{Family 1.-Umbilicated.}

Scientific Name.

Crenellus

Thermalis ......

Labeo..........

Ligatus $\ldots \ldots$

Foliaceus

Limbatus .......

Carinatus ......

Separatista......

Niveus .........

Helicoides ......
Locality.

Denmark, Britain, Pisa.

Jamaica .............

.....................

..............

Coromandel ..........

Jamaica ..............

Indian Seas ...........

Nicobar Isles ..........

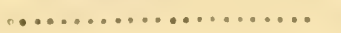

Common Nume.

Crenated Turbo

Fresh water do ..

White lipp'd do .

Ligature .. do ..

Leafy .... do ..

Shouldered do...

Keeled .... do ..

Three-keeled do .

Snowy .... do ..

Brown aiczac do

Family 2.-Imperforate.

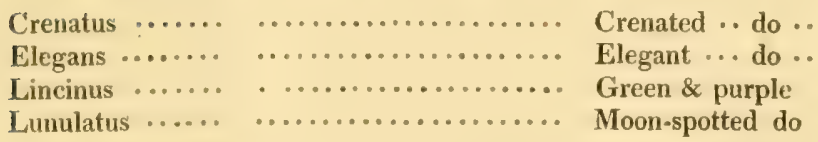

Divisrox VIl.-Shell oblong, glossy, beautifully marked with various colors, and aperture sub-ovate.

Phasianus ..... Van Dieman's Land ... Pheasant .. do .. Inflatus ...... Ditto .............. Inflated $\ldots$. do .. Pullns ......... Britain .............. Painted ... do .. 
Drvision VIII.-Shell subcylindrical, obtuse at both ends, and aperture semi-ovate.

Famicy 1.-Aperture toothed.

Scientific Name.

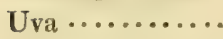

Mumia .........

Alvearia ........

Quinquedentatus.

Tridens ........

Juniperi ........

Muscorum ......

Sexdentatus ....

Carychium .....

\section{Locality.}

Coast of Bretagny

America.............

St. Domingo, Guadaloupe

France ...............

Britain ..............

Britain, Paris, Saxony .. Juniper ... do ..

Europe, under moss .... Moss...... do ..

West of England .. ... Six-tooth'd do ..

Britain .............. Minute-tooth'd do

\section{Reversed Shells}

Bidens ....... Britain, France, Italy ... Double-tooth'd do Lamiuatus ..... England, Europe .... Laminated do .. Biplicatus ...... Ditto ............. Double-plaited do Corrugatus .... Languedoc, Provence .. Wrinkled . do .. Nigricans ...... England, France .... Black .... do .. Labiatus ...... Britain ............ Reversed .. do .. Perversus ..... England ........... Reversed .. do .. Quadridens .... Paris, France ........ Four-tooth'd do .. Vertigo ....... Sandwich, Denmark .... Vertigo ... do ..

Famix 2.-Aperture wilhout teetle.

Cylindrus...... Jamaica ........... Cylindrical do.. Croceus ....... ................. Orange $\ldots$... do .. Sulcatus ....... Ceylon ........... Sulcated .. do .. Corneus ....... .................. Horny $\ldots$. do .. Reflexus........................ Reflected ... do .. Auriscalpium ... Mediterranean ........ Ear-picker do.. 
UNIVALVES —TURBO.

Scientific Name.

Politus.........

Subulatus......

Decussatus .....
Locality.

Britain

Ditto
Common Name.

Polished Turbo..

Awl-shap'd do ..

Decussated do ..

\section{Drvision IX.-Shell turreted.}

\begin{tabular}{|c|c|c|}
\hline is $\ldots .$. . & & \\
\hline catus ...... & Tranquebar .......... & Large ... do . \\
\hline ingulus $\ldots$. & Ditto...$\ldots \ldots \ldots \ldots$ & \\
\hline atus.... . & Britain, Persia, Mediter. & \\
\hline $\operatorname{aris} \ldots .$. & & \\
\hline Obsoletus $\ldots .$. & & \\
\hline Exoletus ...... & h of Europe, Britain & \\
\hline$\cdots \cdots$ & pean Seas, Sweden & \\
\hline dis $\ldots . .$. & China $\ldots . . . . . . .$. & \\
\hline us $\cdots \cdots$. & $\cdots \cdots \cdots \cdots \cdots \cdots \cdots \cdots$ & Vai \\
\hline 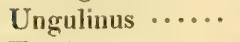 & gean Ocean ....... & Dc \\
\hline $\operatorname{lum} \cdot \ldots$ & ar Isles $\ldots \ldots \ldots$. & $\cdots$ \\
\hline the & $\cdots \ldots \ldots \ldots$ & \\
\hline urris Thomæe .. & St. Thomas ............ & Tower .... do \\
\hline
\end{tabular}

Division X.-Shell depressed.

Nautileus ..... Britain, Germany ..... Nautilus Turbo ..

Cristatus ...... Denmark, Britain ..... Small crested do .

Depressus ..... Cornwall, Devonshire .. Minute flattish do

Serpuloides .... Devonshire .......... Serpula ... do ..

Ludus ........ South Seas .......... Green-spotted do

Marginellus .... ................. Reflected lip do .. 



\section{HELIX. - SNaIl or Spiral.}

\section{DESCRIPTION OF PLATE XXIX.}

Div. I. - Fam. 3. Fig. 3. H. gualteriana.

Div. IV.-Fam. 1. Fig. 1. H. dextra. Div. VI.-Fig. 5. H. glauca.

Div. V.-Fig. 2. H. amarula. Div. VII.-Fig. 4. H. scarabæus. Drv. XII.-Fam, 1. Fig. 6. H. decollata.

Shell univalve, spiral, subrliaphanous, brittle; aperture contrated, semilunar, or roundish.

THE numerous species which compose this extensive genus are principally land or fresh water shells, a very few only being the produce of the ocean. They are generally of a delicate and brittle structure, and sometimes transparent.

Among the carinated Helices, which constitute the first division, may be particular.sed the $H$. lapicida, $H$. marginata, and H. cicatricosa. The more compressed or flattened species are usually called Antique Lamps; the H. lampas, H. carocolla, and H. lucerna are illustrative specimens.

The $H$. cornea and $H$. vortex are characteristic of the two families of the depressed species of the second division.

The third division is distinguished by the sub-lunate form of the aperture, and contains some of the most rare and beautiful species of the genus. Of these the H. sultana and H. hrmastoma are most celebrated, the latter, in particular, for its elegant bandings and rosecolored lip. The H. pomatia is an inhabitant of the 
woods of Europe, and was first introduced into this country by Sir Kenelm Digby, for medical purposes. The animal (which was considered a luxury by the Romans) is oviparous, and very tenacious of life; towards winter it covers its aperture with a calcareous lid, resembling an operculum, and remains in a torpid state until the spring.

The shells of the fourth division have a ventricose form, and resemble those of the sixth division of the genus Bulla, as is there observed. The $H$. ovalis and $H$. oblonga are the most characteristic; the eggs of the animal are perfectly elliptical, and are nearly the size of those of the common sparrow.

The H. amarula of the fifth division is the only coronated species of the genus.

The shells of the sixth division are very globose, and have their whorls much produced: the $H_{\text {. ampullacea }}$ may be referred to as an example.

The animal of the $H$. ianthina, of the eighth division, has the property of emitting a phosphorescent light, and stains the hand of a purple color, not easily removed: they are found in great numbers, floating on marine substances.

The eleventh division contains those species which are usually found in stagnant waters; they have a ventricose form, and are remarkably fragile and pellucid.

This genus has also its turreted class, forming the twelfth division. The H. decollata and H. columna are illustrative of the two families.

The most rare and beautiful species are the H.ringens, H. tricarinata, H. otis, H. hæmastoma, and H. columua.

There are many species of this genus which inhabit 
aquatic plants, others are found on trees and shrubs, and some harbour in decayed wood.

The term $\varepsilon_{1}, \xi_{\xi}$ (Helix) as applied to this genus, is extremely indefinite, it refers only to the spiral form of the shell, and might with equal propriety be applied to any of the other turbinated genera.

Drviston 1.-Shell with a carinated margin on the body-whort.

FAмILY 1.-Umbilicated and depressed.

Scientific Name.

Lapicida

Marginata .......

Cicatricosa .....

Albella ........

Albina..........

Rotundata .......

Lrvipes .........

Exilis ..........

Cantiana .........

Rufescens.......

Crenulata $\ldots . .$.

Annulata .......

Fontana ........

Turcica ........
Locality.

Europe .............. Rock Suail ...

Jamaica ............. Margined . do ..

S. Seas, China, Jamaica - Reversed.. do ..

Europe, North America - Whitish .. do ..

................... Minute-white do

England,Denuark, France Small radiated do

Guinea, Tranquebar .... Reverse-whorl'd

Tranquebar .......... White-striped do

Britain,(particularlyKent) Kent .... do..

Eugland, Saxony ... ... Reddish .. do ..

England, France ....... Black-tipp'd do ..

................... Ringed ... do ..

England ............. Fresh-water do ..

Mogadore, Morocco .... Turkish ... do ..

FaniLy 2.-Umbilicated and convex.

Cornu ........ New Zealand ........ Large horn do ..

Oculus-capri .... Asia, Pulo Condore .... Goat's eye. do ..

Involvulus ..... ................ White-reflected .

Striatula ...... Algiers ............ Striated .. do .

Algira......... Africa, Amboyna,Jamaica Yellowish . do ..

Leucas ........ Africa ............. Purple-lined do ..

Trochoides..... East Indies............ Angular-mouth do

Incarnata ...... Denmark, Germany .... Flesh-color'd do.. 
Scientific Name.

Maculosi .......

Corrugata ......

Pellis-serpentis ..

Avellana........
Locality.

\section{Common Name.} Spotted Sunil .. Otaheile, Lucania ...... Wrinkled . do .. Sontlı America ......... Suake s-skin do... New Zealand ......... Hazel sut. . do ..

FAmrLy S.-Imperforated and depressed.

Lampas

Carocolla $\ldots . .$.

Gualteriana... .

Faba
Orange-lip do .. America.............. Large brown do . Spain ............... Gualter's .. do .. Otaheite ............. Bean-shap'd do ..

FamxLy 4.-Imperforated, and convex or ventricose.

Vermiculata.... Italy, Portugal ....... Rough dotínd do Cornu-militare .. Germany ............ Buyle-horn do .. Gothica ....... Sweden ............ Donbtful .. do .. Scabra ....... Janıica .......... Rough .... do ..

\section{FAmixy 5.-Umbilicated, and aperture tonthed.}

Punctata...... Virginia, Saxony ...... Punchured . do.. Unidentata..... Ceylon ............. One-tooth d do ..

\section{Famiry 6-Imperforated and aperture toothed.}

Simuata ....... America, Barbad Jamaica Sinuous ... do .. Lncerna ....... East Lndies, Jamaica .... Lamp .... do .. lychucus ..... Janaica ............. T'op-shap'd do .. Cepa........ Jmaica ............ Onion .... do .. Nux-deuticulita . ................. Nut .... do . * Verruca ........................ Wart-lipped do ..

Famis 7.-Imperforate and convex, with the apesture toothed sand turned upwards. 
Famrux 8.-Umbilicated and depressed, aperture ear-shaped, distorted, toothed, and simated, with a marginated lip.

Scientific Name.
Otis $\ldots \ldots \ldots \ldots$ East Indies.......... Plaited Lamp ..

Drvision II.-Shell depressed, and whorl coiled horizontally.

\section{Family 1.-Umbilicated.}

Cornea ........ Stagnant watersin Europe Horn Snail ... Similis ....... Denmark, Berliu ...... Dotted ... do .. Spirorbis ...... Britain, France ........ Small concave do Polygrata ...... ................. Many-whlorl'd do Coutorta....... Europe............ Coiled ... do .. Alba ......... Fighand, Dennark ... White... do .. Crystalliua..... Ditto, ditto....... Crystal ... do .. Cormu-arietis ... An boyna............ Rams horn do.. Cormu-venatorium ................. Hunter's horn do

Famíу 2.-Imperforate and keeled.

Planorbis ...... Europe............. Notch-lipp'd do.. Complanata .... Ditto.............. Flat-umbilicated

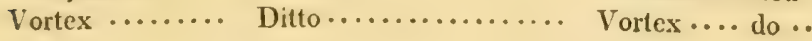

Division III.-Shell with the aperture sub-lunate.

Famix 1.-Umbilicated and depressed.

Ericetorum .... England, France, Italy .. Heath .... do .. 
Scientific Name.

Strigata ........

Incisa ..........

Pisana ..........

Nitida

Tenuis .........

Cellaria ........

Obvoluta .......

Zonaria ........

Striata.........

Ungulina .......

Itala .........

Citrina ........

Rapa..........
Locality.

Italy, England ....... Girdled Snail ..

East Indies ........... Slit margin'd do

England, France, Spain .. Pisa ..... do ..

England,France,Denmark Pellucid .. do ..

Penzance, Newbury .... Thin .... do ..

Inhabits cellars ....... Cellar .... do ..

France, Saxony, Italy ... Small whitelipp'd Barbary, South of Europe Zoned .... do ..

Saxony .............. Striated .. do .. India ............... Tawny-horn do .. Europe .............. Brown-banded do Jamaica ............. Citron .... do .. ................. Single band do ..

\section{Minute Shells.}

Minima........

Hispida

Umbilicata ......

Costata........

Pulchella .......

Trochulus ......

Aculeata .......

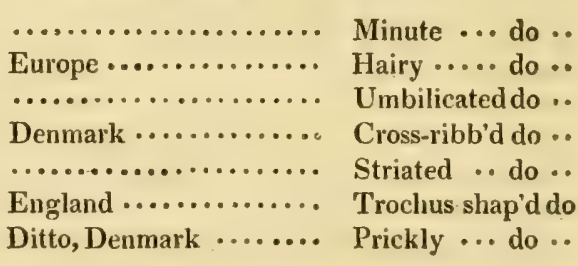

FAMхч 2.-Umbilicated and sub-globular.

Castanea

Globulus .......

Lucana

Arbustorum ....

Fruticum .......

Fulva .........

Nemorensis .....

Vittata .........

Lusitanica .....

Hispana ........

Vitrea ..........

Pomatia
Chesnut ... do ..

Globular .. do .. Transparent do .. Single streaked do Six-whorl'd do .. Amber.... do .. Polished .. do .. Ribbon ... do .. Lusitanian - do .. Spanish ... do .. Brittle .... do .. Edible.... do .. 
Scientific Name.

Cincta........

Rosacea

Extensa
Locality.

Common Name. Red-banded Snail Flesh-color'd do Four-whorl'd do

FamrLy 3.-Imperforate and sub-globular.

Jamaicensis .... Jamaica ............ Jamaica .. do ..

Rhodia ....... Island of Rhodes ..... Rhodian .. do ..

Albolabris ...... .................. White lipped do .

Nemoralis ..... Europe............. Varied .... do ..

Cartusiana ..... Near Paris .......... Carthusian do ..

Lucorum ....... Europe ............. Brown lipp'd do

Grisea........ Europe............ Grey .... do ..

Sultana ....... New Zealand ......... Variegated do..

Hrmastoma .... Ceylon ............. Rose-lipped do..

Lactea ........ Jamaica ............ Milky .... do ..

Picta ......... Amboyna, China..... Painted ... do ..

Versicolor ....................... Diversified do..

Aperta ........ St. Croix ............ Gaping ... do ..

Fusca ..................... Britain .... Brown ... do

Pellucida ...... Saxony, Denmark ..... Transparent do ..

FAMLY 4.-Imperforate, and spive rather produced.

Vivipara....... Britain ............ Viviparons do ..

Fasciata ...... Italy ............. Banded ... do ..

Dissimilis ....... Tranquebar.......... Black-lipped do .

Angularis ....... Canton ............. Angular .. do ..

FamiL 5.-Umbilicated and spire produced.

Scalaris ....... France ............. Produced . do ..

Division IV.-Shell ovate, oblong, ventricose, and aperture ovate

FaMiLY 1.-Umbilicated.

Ovata ........ East Iudies, Tranquebar. Oval ..... do .. 
Scientific Name.

Lutaria

Oblonga .......

Flammen .......

Kambeul ........

Pileus

Trifusciata ......

Bontia .........

Labiosa ........

Otaheitana......

Læva .........

Dextra .........

Stagnorum .....

Obscirra.......

Lackhamensis ..

Detrita ........

Guadaloupensis .

Substriata ......
Locality.

East \& W. Indies, Africa

Guinea.............

Senegal .............

...................

Tranquebar ............

Dillo

India

Otalseite ............

East Indies

West Indies 0.000 .00 .0 .

West Indies .............

Holland .............

Britain

......................

Italy ................

Guadaloupe ............

Britain ..............
Common Name.

Mud Suail ...

Oblong . . do ..

Zebra .... do ..

Kambeul .. do ..

Red\& yel'w strip'd

Three-banded do

Brown monthid do

Lipped ... do ..

Otaheite .. do ..

Party-color ${ }^{\circ} d$ do

Yellow.... do ..

Barley-corn do ... Small brown do

Lackham's do ..

Smooth rayed do

Guadaloupe do ..

Substriated do ..

Famix 2.-Imperforate.

Recta .........

Interrupta ......

* Papyracea ....

Arenaria.......

Aspera ........

Sub-cylindrica ..

Pella ...........

Pupa..........

Barbara

...................

Straight... do ..

Tesselated . do .

Rio Janciro ........... Fragile ... do ..

Rimini .............. Minute sand do ..

Coromandel .......... Rough-striated do

Europe.............. Sub.cylindrical .

Iceland .............. Small red brown

Mauritiana .......... Little .... do ..

Algiers.............. Barbary ... . do ..

Drvision V. - Shell orate-oblong, with the whorls transversely keeled and coronated.

Amarula

Asia, Gauges

Mitre.... do.. 
Drvision VI.-Shell sub-globular, ventricose, umbilicated, and aperture ovate-oblong.

Scientific Name.

Lorality.

Common Name.

Ampullacea ..... East \& West ludies .... Smooth-girdled .

Urceus ....... America............. Cocoa-ıut . do ..

Glauca ........ Guadaloupe.......... Greyish brown do

Lacuna ....... Britain ............. Gutter lipp'd do .

Drvisron VII.-Shell with the whorls longitudinally angulated on both sides.

Scarabæus .... A Asia, Amboyna, China - Cockchafer do .. Afra.......... Goree............. African ... do ..

Drvision VIII.-Shell umbilicated, roundish, obtuse, diaphanous, brittle, and aperture sub-triangular.

Ianthina ....... \$. Seas, Madagascar.... Violet .... do .. Globosa ....... Madagascar .......... Globose... do ..

Drvision IX.-Shell conical, obtuse, distorted, the side opposite the aperture gibbous, aperture compressed.

Lyonetiana .... Isle of France........ Lyonet's .. do ..

Division X.-Shell sub-ımbilicated, pyramidal, and summit obtuse.

Epystylium ..... South Seas .......... Bce-hive.. do ..

Papillz ........ ................. Nipple... do.. 
Drvision XI.-Shell ventricose, pellucid, and aperture ovate.

\begin{tabular}{|c|c|c|}
\hline Scientific Name. & Locality. & Common Name. \\
\hline Stagnalis ....... & Britain .............. & Lake Snail .... \\
\hline Fragilis ........ & 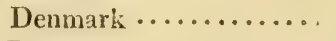 & Brittle.... do .. \\
\hline Palustris ........ & 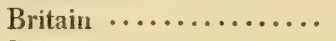 & Marsh .... do .. \\
\hline Fossaria ........ & Britain .............. & Ditch .... do .. \\
\hline Albicans.... . & Hamburg ........... & White ... do .. \\
\hline Putris ......... & Britain .............. & Thin yellowish $d_{0}$ \\
\hline Peregra......... & Fredericksburg, Seine .. & Horny .... do .. \\
\hline Limosa ........ & Europe.............. & Rough .... do .. \\
\hline Truncatula ...... & 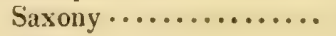 & Truncated . do .. \\
\hline Inflata...$\ldots \ldots$ & Ditto............ & Inflated ... do .. \\
\hline Opaca.......... & Hamburg............. & Opaque ... do .. \\
\hline Tentaculata.... & Europe ............... & Dusky .... do .. \\
\hline Lutea .......... & Devonshire ........... & Yellow.... do... \\
\hline Sicula......... & 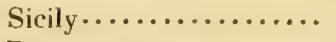 & Sicilian .... do .. \\
\hline Glutinosa...... & 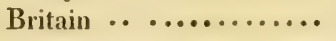 & Membranous do \\
\hline Lavigata ....... & 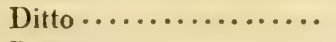 & Smooth flesh color \\
\hline Balthica ........ & Baltic...$\ldots \ldots \ldots$ & Baltic.... do .. \\
\hline Neritoidea ...... & $\ldots \ldots \ldots \ldots \ldots \ldots \ldots$ & Nerite-shaped do. \\
\hline
\end{tabular}

FAMILY 2,-Umbilicated.

Repanda ....... Thangelstadt ........ Ventricose - do . Canalis ........ Britain ............ Channelled do.. Auricularia .... Britain ............. Eared ... do ..

Drvision XII. -Turreted.

FamiLY 1.-Apex truncated.

Consolidata .... Surinam ............ Flat tipp'd do ..

Decollata ..... South of Europe ...... Truncated . do ..

Truncata...... St. Domingo ......... Flag ..... do .. 
UNIVALVES _ HELIX.

Scientific Name.

Calcaria

Contorta.plicata.

\section{Locality.}

East Indies

Denmark

FamiLy 2.-Apex acute。

Cuspidata ..... India $\ldots . . . . . . .$. Pointed .... do ..

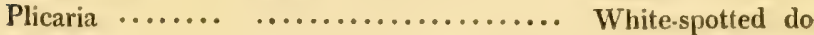

Undulata ...... ................ Waved .... do..

Vibex ........................ Red-marked do ..

Crenata ....... Madagascar.......... Crenated .. do ..

Fuscata ...... East Indies ........ Brown clouded do

Peregrina...... Britain, West Indies .... Eight-whorl'd do

Octona ....... West Indies .......... Slender ... do ..

Columna....... Guinea, Jamaica ...... Column ... do ..

Incumbens ..................... Tawny-strip'd do

Acuta ......... Britain, France, Barbary Donble-banded do

Undata ....... New Holland ........ Undulated . do ..

Fluviatilis...... Coromandel ......... River ..... do ..

Turbinata ..... Danube ............ Turbinated do ..

Cariula....... Guadaloupe.......... Brown lin'd do..

Drvisıon XIII.-Shell depressed, spire flattish, aperture very largc, exposing the whole inside.

Perspicua ....... Mediterranean ........ Large mouth do . Haliotoidea ..... ................. Veluus' ear. do .. 

UNIVALVES - NERITA.

NERITA._Nerite or Hoof-Shell.

DESCRIPTION OF PLATE XXX.

Div. I. - Fam. 1. Fig. 5. N. vitellus.

Fam. 2. Fig. 6. N. canrena.

Fam. 3. Fig. 4. N. albumen.

Drr. II.-Fam. 1. Fig. 2. N. corona.

Fam. 2. Fig. 3. N. fluviatilis.

Drv.1II._Fam.2. Fig. 1. N. polita.

Fam. 2. Fin. 7. N. peloronta.

Shell univalve, spiral, gibbous; aperture semiorbicular or semilnear; pillar-lip transversely truncate, flattish.

THERE is considerable variation in the form and markings of the Neritæ: some are spiral, with prominent whorls; others have their whorls partly or wholly concealed: some again are umbilicated, while others are perfectly entire and solid; and many have the unbilicus partially covered by a repand lip, or fissurated nodule.

The back of the shell is sometimes covered with strong, elevated ribs; and in a few species with spines; it is often only minutely striated, and has frequently a perfectly smooth surface, and a brilliant polish.

Among those species which are umbilicated, and form the first division, may be mentioned the N. vitellus, $N$. canrena, (of which there are many beautiful varieties), N. cancellata, N. glauciua, and N. mammilla: 
the most common variety of the latter shell is entirely white, and has the appearance of porcelain; but the rarer inclines to a brownish orange.

The species which constitute the next division are imperforated and toothless: of these the N. corona, which has its whorls crowned with spines of unequal length, and the N. fluviatilis, may be adduced as examples.

The species of the third division are distinguished from those of the preceding, by having one or both of the lips toothed. The N. pulligera, N. polita, N. undulata, N. exuvia, and N. chamæleon, are characteristic of the several families.

The most beautiful species of the genus is the $\mathrm{N}$. polita, of which the most rare variety has three or four bright crimson bands, on a dark mottled ground, running in a parallel direction with the convolutions of the shell; they are frequently worn as ornaments by the Indians.

The different species of Nerita are principally produced in the African, American, Indian, and European seas.

This genus has received the name of Nypirns from its species having been supposed by the antient naturalists to have the power of swimming in the ocean. 


\section{Drvisron I.-Shell umbilicated.}

Famix 1.-With the umbilicus rather large, nearly pervions.

Scientific Name.

Vitellus ....... Mauritius, Amboyna, Asia

Punctata....... Mediterranean .........

Cruentata....... Tranquebar............

Viltata

West Indies

Morocco

Pallidula..... England
Common Name.

Clouded yellow $\mathrm{N}$. Punctured - do .. Red-spotted do .. Wrinkled , do .. Pibbon ... do .. Pallid .... do ..

FaniLY 2.-With the umbilicus bifid.

Canrena ....... All parts of the world ... Taby-cat .. do .. Cancellata ...... West Indies .......... Latticed .. do .. Sulcata.......................... Grooved .. do .. Spadicea....... Mauritius............ Chesnut .. do .. Rufa ......... East \& West Indies .... Reddish... do ..

FaMiLy 3.-With the umbilicus nearly closed by a callus, or by the inner lip.

Glaucina ....... Europe, Africa, America, East Indies......... Livid .... do ..

Orientalis ..... E. Indies, Bay of Naples Eastern ... do .. Maroccana..... Africa, W. Indies, Naples Wave-striped do Arachnoiden .... ................... Spider's web do . Albumen ...... Amboyna, C. G. Hope, Molúccas ........... Liver color'd do Mammilla ..... Do.Mauritius, Tranquebar Breast .... do .. Papilla ........ N. Zealand, Tranquebar Nipple .. do .. Melanostoma.... Mauritius, West Indies .. Brown pillar do . Ambigua ...... Mediterranean ......... Ambiguous do ..

FAMILY 4.-With the umbilicus toothed.

Fulminea ...... Senegal, Moluccas .... Z Ziczac ... do .. 


\section{Drvisron II.-Shell imperforate and toothless.}

\section{FaMILX 1.-Spinous.}

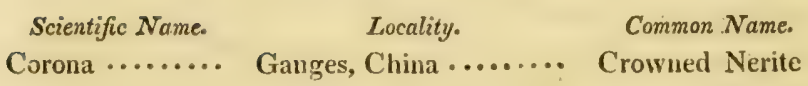

Famriy 2.-Without spines.

Radula ........ Amboyna, Tranquebar - Rough-ribbed do. Magdalena..... Magdalen Isles........ Magdalen • do .. Coruea ........ Red Sea ............. Horny .... do .. Fluviatilis .... Europe ............. River ..... do .. Littoralis ...... Europe ............. Strand .... do .. Lacustris ...... Ditto............... Lake .... do .. Dubia............................ Black mark do .. Marginata....................... Margined . do ..

Divisron III.-Shell imperforate and toothet.

FamiLx 1.-With the imer lip toothed.

Pulligera ...... India, Amboyna, So. Seas Reddish ... do .. Aculeata....... East ludies ........... Spinous ... do .. Pupa.......... Jamaica ............. Black \& white do Bidens ........ New Zealand ......... Double toothid do Flavescens ..... Nicobar Isles ......... Yellowish. do .. Viridis........ West Indies ........... Green .... do .. Virginea....... Mediterranean, W. Indies Guinea-fowl do . Turrita........ West Indies........... Turreted . do .. Piperina ...... Malabar.............. Triangular spott'd Larva .................... Amboyna Broad band do .. Ascensionis .... Island of Ascension ..... Ascensiou . . do .. Malaccensis..... Malacea ........... Malacca .. do .. Hieroglyphica .. East Indies ........... Hieroglyphic do 
Fanrux 2.-With both lips tostherl or crenated.

Scientific Name.

Polita

Peloronta ..... Asia, South Seas . Bant, W.

Maxima .........

Histrio .........

Lineata ........

Versicolor $\cdots . .$. .

Pica...........

Stella .......... Tessellata ..... W. Indies, Magdalen Isles Tessellated. do ..
Common Name. Smooth Nerite . Bleeding-tooth do Great ..... do ... Harlequin - do . Lined .... do .. Many color'd do . Magpie.... do .. Star ..... do ...

Faмгу 3.- With the inner lip toothed and wrinkled.

Atrata ....... West Indies, Goree .... Smooth black do

Nigerrima ..... South Seas .......... Black .... do ..

Antillarum ..... West Indies......... W rinkle-lip do .. Plicata ........ Mauritius, Tranquebar .. Horse-tooth do .. Flammea ...... West Indies.......... Flame .... do .. Grossa ....... Asiatic Ocean, Moluccas - Red thrush do .. Undulata ...... East Indies .......... Thin wav'd do .. Quadricolor..... Red Sea............. Four-color'd do ..

Famicy 4.-With the inner lip toothed and tuberculated.

Albicilla ...... Manilla, China, Hitoe .. Pimple-lip do .. Exuvia....... Jamaica, Asia, America - Exuvia ... do .. Fulgurans..... West Iudies .......... Lightning . do ..

Famux 5.-With the inner lip toothed, wrinkled, and tuberculated.

Plexa ......... Tranquebar, Ceylon, Nicobar............ Thrush ... do ..

Costata....... Nicobar Isles......... Ribbed ... do .. Chamæleon .... Banda, Moluccas .... Chameleon do.. Undata....... East Indies, Africa .... Waved .... do .. 



\section{HALIOTiS. - Sea-ear or Ear-Shell.}

\section{DESCRIPTION OF PLATE XXXI.}

Drv. I. F Fam. 1. Fig.2. H. chracherodii.

Fam. 1. Fig. 5. H. pulcherrima.
Fam. 1. Fig. 4. H. iris.

Fam. 2. Fig, 3. H. asinina.

Drr. II.-Fig. 1. H. imperforata.

Shell univalve, dilated, ear-shaped, generally with a longitudinal row of orifices along the surface; spire lateral, and nearly concealed.

THE general form and appearance of the shells of this beautiful genus are so similar, that it is often difficult to distinguish and arrange the species. In shape they greatly resemble the human ear; the only exception is the $H$. asinina, which has received its name from being more elongated than any of the other species.

The exterior is generally composed of rugæ or tuberculations, over which pass approximate, elevated strix: but as it is usually loaded with marine substances, or much decayed and worn, this character is seldom olservable. The interior of the Haliotis is remarkable for its natural and splendid iridescence, which forms a striking contrast with the sombre appearance of its exterior. The iridescent colors are exhibited in the highest splendor, in the $H_{\text {. iris, }} \mathbf{H}$. rufescens, and $\boldsymbol{H}_{\text {. }}$ splendens.

The back of the Haliotides of the first division is furnished with a row of orifices near the margin, varying in number from eight to thirty-eight; of these from 
three to seven are generally open, and the others perfectly closed. The $H$. parva is remarkable for the large elevated rib or angle on its back.

The second division consists of the imperforated species. The H. imperforata, which has an ovate form, with an exserted spire, and prickly ribs, is a characteristic specimen.

The species which may be noticed as rarieties of the genus are the H. pulcherrima, H. glabra, H. australis, H. parva, H. imperforata, and H. impertusa.

The Haliotides are found on the shores of Europe, Africa, and India, where, like the Limpets, they adhere to the rocks, from which they are with difficulty removed.

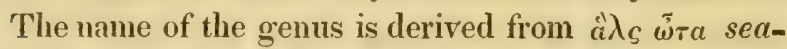
ears, in reference to the liabitat and form of the shell.

Divisiox 1.-Shell perforated.

Family 1.-Roundish or ovate.

Scientific Name. Locality.

Common Name.

Midæ .......... East Indies, Mauritius, Cape of Good Hope - Midas' Ear ...

Pulcherrima.... King George's Sound .. Beautiful .. do ..

Virginea...... New Zealand ........ Iridescent . do ..

Tuberculata .... Europe, West Indies .... Common .. do ..

Striata......... Asiatic Ocean, Barbary - Wrinkled . do ..

Bistriata ....... Africa ............ Double-lined do..

Varia ........ East Indies.......... Rongh. striated do

Marmorata..... Africa, East Indies .... Marbled .. do ..

Glabra .. ..... South Seas ......... Smooth mottled

Australis ..... New Zealand ........ Rough plaited do

Gigantea ...... N. Holland, N. S. Wales Gigantic .. do ..

Iris ....... New Zealand ........ Iris ..... do ..

Cracherodii ..... Califomia .......... Cracherode's do 
UNIVALVES - HALIOTIS.

Scientific Name.

Ovina

Parva ........ Africa, Mauritius, China

Rufescens . .... South Seas

* Splendens.... Califormia

* Corrugata ....
Locality.

Ditto ............... Corrugated do..

Asinina ....... I. Ocean, Amboyna, China Ass's Ear . do ..

Drvision 11.--Shell imperforate.

Imperforata ... East Indies, Red Sea ... Carinated . do ..

Impertusa ..... E. Indies . ......... Imperforate do ..

* Dubia ....... South Seas .......... Doubtful .. do . 



\section{ORDER III.}

\section{Etmivalueg.}

II. WITHOUT A REGULAR SPIRE.

\section{PATELLA._Limpet or Dish-Shell.}

DESCRIPTION OF PLATE XXXII.
Drv. I. -Fig.4. P. testudinaria. Div. IV.-Fig.2. P. ungarica.
Fig. 7. P. clealandi. Dir. V.-Fig. 1. P. fissura.
Drv. III.-Fig. 5. P. caffra. Drv. VI.-Fig. 3. P. equestris.
Drv. VII.-Fig, 6. P. porcellana.

Shell univalve, subconic, shaped like a bason, without a spire.

THE Patellæ, though a very numerous genus, present but little variation in form, the species, with very few exceptions, generally approximating to the shape of a cone, with its apex a little blunted. The colors and structure of their exterior are extremely diversified; some being perfectly smooth, while others are strongly granulated; and many are deeply striated, or cover-ed with elevated tuberculated ribs.

The distinctions of the divisions are strongly marked: the first comprises the species which have the margin entire, and are not pointed at the summit. Those 
most deserving notice are the P.testudinaria, which has generally its interior of a silvery hue; the $P$. areolata, P. flammea, and P. compressa, the latter being remarkable for its narrow and lengthened form.

The shells of a compressed form, and having their margins angularly or irregularly toothed, constitute the second division; such are the P. saccharina, P. granularis, P. granatina, and $\mathbf{P}$. sanguinolenta. The $\mathbf{P}$. vulgata is the Common Limpet, so abundantly found on the British and European shores.

The third division includes those species which, on account of the perforation in the summit, are usually called Key-hole Limpets. The principal are the $\mathbf{P}$. græca, P. nimbosa, P. caffra, P. picta, P. perforata, and P. macroschisma.

The next division comprehends those species which have the summit pointed and recurved: the P. ungarica, the most remarkable, is a beautiful shell, and, from its similarity of shape, called the Fool's-cap:the exterior is usually of a pale fawn color, and the outer margin is bordered with a fringed epidermis; when the interior is of a very bright pink color, this Limpet is considered more valuable. The P. lutea has some resemblance to an Haliotis, but the flatness and ear-shaped form of the latter genus, is a sufficient distinction.

The shells of the fifth division have a marginated fissure, which is most conspicuous in the $\mathbf{P}$. fissura.

The curious internal appendage which characterizes the shells of the sixth division, is strikingly observ- 
able in the P. equestris, P. sinensis, and P. duplicata; these are commonly designated Cup-and-saucer Limpets.

The last division has a very peculiar character, the interior being furnished with a transverse partition, giving the shell the appearance of a slipper; the P.neritoidea, P. porcellana, and P. fornicata resemble Nerites.

The rarest shells of this genus are the P. personata, P. trochiformis, P. mytiliformis, and P. macroschisma.

The Limpets are usually found adhering by their base to rocks, stones, fuci, and other marine substances, from which they are not easily detached. They inhabit the Indian, Southern, European, Northern, and Mediterranean seas, the American and Indian Islands, the Atlantic, and the shores of China, Greenland, and lceland.

The Patellæ derive their name from their resemblance to a little dish or buson (Patella).

Division I. - Shell with the summit obtuse, and the margin entive.

Scientific Name.

Pellucida ...... Britain, Norway, Mediterranean ..........

Lrevis........ England, Northeru Ocean Radians ....... New Zealand, 'Terra del Fuego ............. Grey-mottled do Rota ......... E. \& W. Indies ....... Roundish .. do .. Testudinaria .... Norway, East Indies.... Tortoise-shell do. Clealandi ...... Bangor, Ireland ....... Clealand's . do .. Testudinalis ... Norway, St. Domingo .. Small tortoise-shel 
Scientific Name.

Compressa

Mytiliformis ....

Afra .........

Rustica ......

Jamaicensis ....

Stellifera ......

Fusca .........

Areolata .......

Flanmea .......

Indica .........

Vitellina

Lrevigata

Surinamensis ...

Punctulata $\ldots . .$.

Notata........

Cruciata

Reticulata .....

Creca ..........

Virginea ........

Tessellata ......

Fulva ..........

Ambigua .......

Umbellata ......
Locality.

Common Name.

Mauritius, S. Seas, C. G.

Hope ........... Flat-sided Limpet

Ferroe Islands ......... Muscle ... do ..

Cape Manuel, Goree ... African ... do ..

Portugal, Jamaica, China Narrow ribbed do Jamaica ............ Jamaica ... do ..

South Seas .......... Starred ... do ..

Magellan, Falkland Isles Sugar-loaf . do . .

Magellan ............. Pyramidal . do ..

Falkland Isles ........ Agate .... do ..

East Indian Seas . . . . . . Indian .... do ...

Yellow .... do ..

White-tipp'd do

Surinam ............ Surinam .. do ..

Dotted .... do ..

Mediterranean, W.Indies,

Africa .............

Wheat-sheaf do . White cross do.. Mediterranean ........ Reticulated do .. Norway ............. White border'd do Ditto, Swansea ........ Purple rayed do Norway ............ Tessellated do.. Norway ............ Orange tawny do New Holland ......... White duck's bill China, Mauritius ...... Parasol ... do ..

Division II. - Shell with the margin angular, or irvegularly toothed.

Laciniosa .......

Plicata .........

Monopis .........

Saccharina.....

Angulosa .......

Repanda ........

Tenuis .........

Margaritacea ...
Amboyna .............

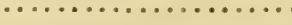

West Indies ..........

Amboyna, China, C. G.

Hope .............

Provence .............

Island of Cerigo ........

.....................

Iceland, Patagonia .....
White-eyed do .. Plaited .... do .. Chesnut streaked Star ...... do .. Angular .. do .. Small sun - do .. Thin amber do .. Great sun - do .. 
UNIVALVES — PATELLA.

Scientific Name.

Barbara .......

Cypria ..........

Oculus-Capri ...

Pentagona ......

Granularis ......

Granatina ......

Chlorosticta ....

Tigrina .........

Ornata.........

Melanogramma

Ferruginea .....

Crenata ........

Sanguinolenta...

Ulyssiponensis ..

Radiata ........

Lugubris ........

Vulgata..... .

Crerulea........

Tuberculata ....

Cochlear ........

\section{Locality.}

Falkland Isles......... Mauritius, New Zealand

Mediterranean, Africa,

France .............

.................. Five-angled do ..

Mauritius, C. G. Hope.- White-grained do

S. Europe, Mauritius, do. Garnet ... do ..

Jamaica ............. Pigeon's throat do

................... Tiger..... do ..

New Zealand .......... Adorned ... do ..

Black ribb'd do

Magellan, Falkland Isles Rusty .... do ... Africa, Lisbon, Mediter. Little grey do .. Africa, Mauritius ...... Rose-streaked do Lisbon ............. Buckler... do .. Nicobar \& Molucca Isles Radiated ... do ... Provence, Cyprus ...... Black ..... do .. Europe .............. Common .. do ... Ditto, Mediterranean .. Blue ...... do .. .................. White pimpled do New Zealand .......... Horse shoo do ..

Drvision IIl.-Shell with the summit perforated.

\begin{tabular}{|c|c|c|}
\hline 1a....... & & \\
\hline Pustula ........ & Mediterranean, W. Indies & Dou \\
\hline Græca ......... & West Indies, Africa ..... & $\mathrm{Ca}$ \\
\hline Atricapilla ...... & Barbadoes ............. & . do. \\
\hline$\ldots \ldots \ldots$ & West Indies ......... & Tube \\
\hline ta $\cdots \cdots$ & …........... & \\
\hline$\ldots \ldots \ldots$ & ope $\ldots \ldots \ldots \ldots$ & . do \\
\hline us $\cdots \cdots$. & ... & ap.. do \\
\hline llum ...... & Fal & Seu \\
\hline$\ldots \ldots \ldots$ & Iagellan ...... & Pai \\
\hline . & W.Indies, Africa,S.Euro & -ribb'd do \\
\hline Nubecula ....... & Mediterranean, Jamaica. & egated do \\
\hline ozonias . & North America ........ & Porphyry $\cdot d$ \\
\hline Tacroschisma ... & Japan ............... & Keyhole $\therefore$ do \\
\hline
\end{tabular}


Division IV.-Shell with the summit pointed and recurved.

\begin{tabular}{|c|c|c|}
\hline Scientific Name. & Locality. & Common Name. \\
\hline Ungarica ....... & anean, Britain .. & Fool's-cap Limper \\
\hline Militaris ........ & st ludies, Engla & Hooked $\because$ do. \\
\hline Antiquata ...... & Ditto $. . . \ldots \ldots \ldots . . . .$. & ated do .. \\
\hline Cochleata ..... & South Seas .......... & White-ridged do \\
\hline Calyptra ........ & N. W. Coast of America & Helmet ... do .. \\
\hline Intorta ........ & S.Seas, W.Indies, England & lo $\cdots$ \\
\hline Cassida ......... & S. Seas, France ....... & Lentil-seed. do .. \\
\hline Tranquebarica .. & Tranquebar, Batavia .... & Brilliant . do .. \\
\hline & $\begin{array}{l}\text { So. Seas, Mediterranean, } \\
\text { West Indies ......... }\end{array}$ & Nip \\
\hline Leucopleura .... & West Indies ........... & \\
\hline ata $\ldots$. & $1 \ldots \ldots \ldots$ & keeled do \\
\hline Pectinata ....... & Mediterranean ........ & d $\cdots$ do. \\
\hline Fuseo-Lutea .... & . $\ldots \ldots \ldots \ldots \ldots$, & wish brown \\
\hline Lutea .......... & Amboyna............ & ow $\cdots$ do $\cdots$ \\
\hline rsa $\ldots \ldots$ & Africa $\ldots \ldots \ldots \ldots \ldots$ & Reverse tipp'd do \\
\hline Lacustris ....... & Lakes in Europe ....... & Lake .... do .. \\
\hline Oblonga........ & Rivers in Europe ....... & Oblong ... do . \\
\hline
\end{tabular}

Division V.-Shell with a marginal fissure.

Fissura ....... Britain, Algiers ...... Slit ..... do .. Incisa ........ Falkland Isles ........ Reticulated slit do Fissurata ..... N. Zealaud, Ceylon .... Rose-color'd do .

Drvision VI.-Shell with an internal appendage at the summit.

Equestris ...... E. \& W.Indies, Amboyna Cup-\&-Saucer L. Neptuni ....... So. Seas, St. Domingo . Neptune's Cap do Tectum....... Batavia, China....... Chinese roof do.. Sinensis ...... Britain, Mediterranean, Batavia........... Chinese bonnet . 
UNIVALVES - PATELLA.

Locality.

Scientific Name.

Auriculata ...... Batavia, W.Indies, Borneo

* Duplicata....
Common Name.

Ear-shap'd do ..

Double.... do ..

Drvisron VII.-Shell with an internal transverse partition.

Trochiformis .... Falkland lsles, Tranquebar Trochus-shap'd do Trochoides ...................... Wave-ribbed do .

Neritoidea ..... Mauritius, Indian Ocean Chambered do ..

Porcellana ..... Indian Ocean, Goree ... Brown spot do ..

Fornicata...... Mediterranean, ditto.... Slipper ... do ..

Aculeata ...... Mauritius, W. Indies.... Spiny ribbed do .

Goreensis...... Goree ............. Sandal .... do ..

Crepidula ...... Mediterraiean, Barbary Trausparent white 



\section{DENTALIUM._- ToOTH OR TUSK-SHELL,}

\section{DESCRIPTION OF PLATE XXXIII.}

Fam. 1. Fig. 1. D. aprinum.

fam. 1. Fig. 2. D. striatum.

Fam. 1. Fig. 3. D. dentalis.
Fam. 1. Fig. 4, D. elephantinum. Fam. 2. Fig. 6. D. politum.

Fam. 3. Fig. 5. D. entalis.

Shell univalve, tubular, straight, or slightly curved, with an undivided cavity open at both ends.

THE shells of this singular genus resemble an elephant's tusk in miniature. The principal distinctions are in magnitude, curvature, and the number of ribs and grooves with which some of the species are marked.

The species of the first family are distinguished by longitudinal ribs, which in the $\mathbf{D}$. elephantinum generally amount to ten. The D. striatum differs from the D. elephantinum, in having eight ribs, and the interstices striated.

The D. rectum, though nearly allied to the $\mathbf{D}$. elephantinum, is a straight shell, and therefore easily distinguished from it.

The next family comprehends those which are striated ammularly : of these may be mentioned the $\mathbf{D}$. politum, which is finely pointed, solid, and often of a rosy or pinkish color; and the D. eburneum, which is generally an inch and a half long, of a reddish or pale yellow color, with the tip frequently tinged with orange or pink.

The shells of the third family are smooth, or covered with striæ, so minute that they cannot be discovered without the aid of a magnifying glass. The D. pellu- 
cidum is very narrow and thin, and is of a pale topaz color; it is remarkable that this shell does not effervesce in acids.

The Dentalia are principally found in the Indian and European oceans; and a few in the Mediterranean and Northern seas.

The term Dentalium has been applied to this genus, from the marked resemblance which its species bear to a tooth (Dens).

\section{FAnrex 1.-With longitudinal ribs.}

Scientific Name.

Rectum ....... Indian Seas ..........

Elephantinum ... Indian \& European Seas,

Mauritius .......... Elephant's. do ..

Aprinum ...... Indian Seas .......... White ribbed do

Striatum ....... Sicily, Cornwall....... Striated .. do ..

Dentalis ........ Mediterranean,Amboyna,

West of England .... Curved striated do

Fasciatum ...... Sicily ............. Banded ... do ..

Imperforatum ... Sandwich, Falmouth ... Minute-truncated

Family 2.--With annular stria.

Politum ....... India, Sicily ........ Ring-striated do .

Eburneum ...... India .............. Smooth-ivory do .

Trachea ....... Milton in Devonshire .. Minute Windpipe

FamiLY S.-Smooth.

Entalis ....... Britain, India, Norway ... Common .. do .. Corneum ....... African Ocean ........ Horn-color'd do.. Gadus......... British Channel ....... Hake's .... do .. Minutum ...... Mediterranean, Devon .. Minute.... do .. Pellucidum .... North Sea ......... Pellucid ... do.. 


\section{SERPULA._WORM-ShELL.}

\section{DESCRIPTION OF PLATE XXXIV.}

Drv. I.-Fig. 4. S. contortuplicata.

Drv. II.-Fig. 1. S. lumbricalis.
Drv. I1.-Fig. 2. S. anguina. Drv. II.-Fig. 5. S. retorta.

Drv. 1II. -Fig. 3. S. aquaria.

Shell univalve, tubular, gencrally adhering to other substances.

THE construction of the Serpulæe is extremely irregular, and the groups they form are no less diversified. They are invariably tubular, and sometimes present themselves detached, either straight or twisted, but more frequently in clusters spirally entwined, adhering to a variety of other substances.

The colors of the Serpulæ are generally brown, purple, yellow, tawny, pink, or white, and sometimes tinged with green. Of the species which are attached to extraneous substances and form the first division, some are isolated and others collected into large masses, containing many hundred spiral and twisted tubes, curiously interwoven: the shells of the former class have their whorls nearly contiguous, and resemble some of the Helices: such are the S. spirillum and S.spirorbis. The $S$. vermicularis is an illustrative example of the aggregated species.

The second division has also its isolated and aggregated species; to the former belong the S. protensa and S. lumbricalis, which is a flexuous shell, with a spiral 
acute tip, and very much resembles a cork-screw. One of the most remarkable species is the $\mathbf{S}$. anguina, which has a slit or jointed cleft along the spiral convolutions of the shell. The S. muricata has also a longitudinal fissure, and is armed with short spines or prickles; it is usually of a rosy or pink color, and sometimes has its aperture margined.

The well known but rare species the S. aquaria, forms the third division. The larger end of this shell is closed by a convex disk, with numerous small perforations, and generally a longitudinal one in the middle; the whole encircled by a dilated margin of elegant papyraceous tubes, resembling a beautifully plaited ruff or frill; the smaller end is open.

The Indian, African, American, and Northern oceans, supply many species; as also the European, Mediterranean, Adriatic, and Red seas.

Serpula is derived from Serpo, to creep, in reference to the vermiform character of some of the species.

Division I.-Attached to other substances.

Scientific Name.

Spirillum .......

Triquetra .......

Intricata......

Corrugata ......

Contortuplicata .

Goreensis .......

Glomerata.....

Conica .........

Vermicularis ....

'Tubularia ......
Locality.

Europe............ Minute-spiral S.

Ditto, America ....... Three-sided do ..

Mediterranean, Britain .. Intricate .. do ..

Devonshire .......... Wrinkled . do ..

Europe, Mediterranean .. Twisted .. do ..

Goree ............... Goree .... do ..

European Seas ........ Glomerated do .

America, Amboyna .... Conical ... do ..

Britain ............ Round ... do ..

Devonshire ........... Tubular ... do .. 
Scientific Name.

Denticulata .....

Ocrea ...........

Gigantea .......
Locality.

Europe ............. Toothed Serpula .

East Indian Seas ...... Boot-shaped do ..

Caribbee Isles ........ Great.... do ..

\section{Minute Shells.}

Stellaris

Greenland

Rayed pin's-head

Planorbis

Europe

Flat ...... do ..

Minuta

Ditto

Minute.... do ..

Spirorbis .......

Ditto

Tapering .. do ..

Carinata.......

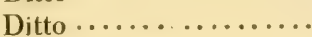

Granulata .....

Cancellata.....

Greenland .

Keeled .... do ..

Heterostropha ...

Britain

Grained ... do ..

Lucida .........

Vitrea

Ditto .................

Grooved .. do ..

Reversed • do ..

Greenland

Shining .. do ..

Glossy ... do ..

\section{Division II.-Detached.}

Semilunum .....

Britain . ...........

Small reed do ..

Incurvata .....

Cereolus .........

Nebulosa ........

Lumbricalis ....

Arenaria .......

Afra ..........

Volvox.........

Anguina ........

Muricata .......

Annularis.......

Retorta

...................

Incurved ... do ..

West Indies .......... Bougie.... do ..

American Seas ......... Clouded tawny do

Amboyna ............ Cork-screw do ..

India ............... Sandy .... do ..

Goree .............. Smooth brown do

E. Indies ............. Caterpillar do ..

Ditto, China, Sicily .... Serpent ... do ..

Indian Ocean .......... Prickly ... do ..

................... Ringed snake do

Mediterranean ......... Retort-shap'd do .

Cornu-copir.... Mauritius, in stones .... Cornucopia do ..

Decussata ..... Barbadoes, America .... Decussated do ..

Proboscidea .... ................ Proboscis .. do ..

Protensa ....... Amboyna .......... Lengthened do ..

Division III.-With a radiated border and perforated disk.

Aquaria ....... Amboyna, Red Sea .... Watering-pot do

02 



\section{TEREDO._SHP-WORM.}

\section{DESCRIPTION OF PLATE XXXV.}

Fig. 1. Section of the T. navalis, exhibiting its chambered structure. Fig. 2. Tubular valve of the same.

Fig. 3. The animal which inhabits the tubular part, shewing the head and terminating valves affixed to it.

Fig. 4. A valve detached from the head, illustrating its interior formation.

Fig. 5. Ditto, terminating valve.

Fig. 6. A group of the T. navalis embedded in wood.

Shell tapering, flexuous, and capable of penetrating wood.

THERE are but four species of this genus at present discovered.

The T. gigantea* is the largest species known, having been found exceeding five fect in length: it is nearly straight, and tapers towards one end, at which an interior tube is visible. It is a native of the Island of Sumatra, where it is found embedded in indurated mud. Some of the largest specimens seen in this country are said to have been thrown up by an earthquake.

The next species is the T. navalis, or common Shipworm, a very thin, cylindrical, and smooth shell, varying in length from four to eight inches; it is generally a little twisted, and rather obtuse or blunt at the tip. It Las the faculty of penetrating the stoutest oaken planks of ships' sides, by means of two valves affixed to the

* Sir E. Home has written a very scientific and interesting description of this siugular shell.-See Phil. Tran. Fc b. 13, 1806. 
head of the animal, resembling the Pholas; it also has two smaller valves of an ovate form, at the other extremity. The destructive effects of this little animal would frequently occasion the loss of the largest vessels, were it not from the singular fact of their generally perforating the wood in the direction of the grain.

The T. utriculus is also cylindrical, undulated, and solid; it is usually about seven inches in length, and found in wood that has lain some time under water. It is white, subpellucid, very much bent, and gradually tapering; the aperture is ovate, divided in the middle by a partition.

The last species is the T. clava, which is found in the seminal vessels of the Xylocarpus Granatum; one end is clavate, the other incurved, narrower, obtuse, and perforated in the middle: the shell is generally flexuous, and has a brownish color; the exterior is rough, but within it is perfectly smooth. It is nearly two inches long, and about half an inch in diameter.

The generic name 'T $\varepsilon_{\rho} \eta \delta$ (in (Teredo) is derived from

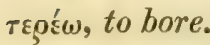

Scientific Name.

Gigantea ...... Sumatra, Ceram ......

Navalis ........ Sides \& bottoms of Ships

Utriculus ...... Wood in the Sea ......

\section{Common Name.}

Gigantic Teredo

Ship..... do ..

Timber ... do ..

Club-shap'd do . . 


\section{SABELLA._SABELLA.}

\section{DESCRIPTION OF PLATE XXXVI.}

Fant. 1. Fig. 1. S. alveolata.

Fam. 1. Fig. 2. S. belgica.

F'am. 1. Fig. 3. S. chrysodon.

Fig. 4. A fragment of a gigantic specimen of the preceding species.

Shell tubular, composed of particles of sand, broken shells, and vegetable substances, united to a membrane by a glutinous cement.

THE covering of the animal of this very extrandinary genus is composed of fragments and particles of elifterent marine and vegetnble productions, adhering to a tubum lar membrane: some are detached, and others are affixed by the base. The S. ammoniatn is covered with fragments of the Comn-Ammonis; the $\$$. Indica, with particles of quartz; and the S. clavatit, with various small stones. The S.alveolata cousists of numerous parallel tubes, communicating by an aperture, forming when in mass the appearance of an lioncy-comb; the tulues are nearly straight, and from two to three inches loing: it arlheres to rocks in extensive clusters. The S. rectangula is one of the largest of the gुomus, amd often measures nine inches in length.

The $S$. vegetabilis, and $S_{\text {. alrundinacea are covered }}$ with fragments of twigs, the bark of stems, and broken pieces of the Tellina Cornea.

The greater number of the species inhahit the rivers and fresh waters of Thuringia and Belgium, and the remainder the Indian, American, Northern, and European seas.

Sabulum, whence Sabellat is derived, signifies fine 
gravel, of which the habitations of most of the species are composed.

FaMILY 1.-Composed of grains of sand, stones, or shells.

\section{Scientific Name.}

Scruposa ....... India, American lslands .

Scabra

Alveolata

Chrysodou.....

Belgica .........

Rectangula... .

Capensis ........

Nigra

Stagnalis .......

Conica .........

Uncinata.....

Sabulosa $\cdots . . .$. .

Ammoniata .....

Helicina ........

Dimidiata ......

Fixa.......

Clavata.....

Marsupialis .....

Norwegica .....

Lumbricalis .....

Indica .........
White sandy S.

America ............. Rough .... do ..

Europe............... Honeycomb do ..

European \& Indian Seas. Pebble ... do ..

European Coasts ...... Tubular .. do ..

.................. Rectangular do ..

Cape of Good Hope .... Cape .... do ..

Thuringia ........... Black ... do ..

Ditto............... River .... do ..

Jena .............. Conic .... do ..

Thuringia ........... Hooked .. do ..

Ditto, Belyium ...... Gravel .... do ..

................... Ammonites do ..

Thuringia ........... Helix ..... do ..

Ditto............... Divided .. do ..

Ditto ................ Stony ... do ..

Ditto .............. Club-shap'd do ..

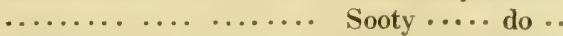

Norway ............. Norway ... do ..

Greenland Seas ....... Coarse ... do ..

Indian Ocean ......... Indian .... do ..

\section{Famixy 2.-Composed of vegetable substances.}

Vegetabilis .... Thuringia ........... Vegetable . do .. Corticalis ...... Ditto............. Bark ..... do ..

Arundinacea .... Ditto............. Reed ..... do ..

Aculeata ...... Ditto............. Twig ..... do .. 


\section{GLOSS A R Y}

or

TERMS USED IN CONCHOLOGY.

Acuminated, terminated in a sharp point.

Anterior, (in Univalves) the part which forms the spire:(in Bivalves), see Margin.

Aperture, the orifice or opening of the shell; it is called angular, when its circumference has several angles: $b i$ marginated, when the right lip forms a double margin: coarctate, contracted: compressed, flattened: yaping, when one of the extremities is wider than the other: linear, when narrow, and the length greatly exceeds the breadth : transverse, when the breadth is greater than the length.

Apex, the tip or small end of a shell.

Articulated, (applied to Multivalves), when the different pieces of which the shell is composed are so strongly united, that they appear to form one shell: (when applied to Bivalves), see Teeth.

Auriculated, having ears.

Base, (applied to Multivalves), the part on which the shell is supported: (to Univalves), the most elevated part of the shell opposite to the spire. 
Beak, Beuked, having the extremity of the base of the shelt elongated and contracted in the form of a beak.

Bearded, when the epidermis is of a bristly or hairy nature, (see plate 18. fig. 2.)

Bifid, forked.

Byssus, a hair-like substance formed by some of the animals of Bivalves, by which they attach themselves to extraneous bodies.

\section{Callons, indurated.}

Callus, a thick excrescence.

Canal, the prolongation of the mouth in a kind of groove or gutter, as in the Murex and Strombus.

Canaliculated, channelled or grooved.

Cardinal, see Teeth.

Carinated, having the form of a boat's keel.

Cartilage, see Ligament.

Cartilaginous, resembling a ligament.

Chambered, when the shell is internally divided by partitions, parallel to the aperture.

Ciliated, surrounded with parallel filaments.

Clavate, club-shaped.

Columella, that part of the shell round which the whorls turn.

Compressed, (in Bivalves), when the valves are nearly flat, or flattened.

Concamerated, see Chambered.

Convolute, when the whorls turn round a lengthened cone, nearly vertical to each other.

Cordiform, heart-shaped.

Coronated, having the apex surrounded with a row of tubercles or spines.

Crenated, Crenulate, having blunt teeth.

Decollated, having the spire or upper part of the shell truncated transversely. 


\section{GLOSSARY.}

Decussated, intersected by striæe at acute angles.

Dentated, having teeth.

Diaphanous, transparent.

Digitated, having projecting claws.

Divaricated, ohliquely striated.

Dorsal, belonging to the back.

Ears, external projections on the sides of the hinge, (see plate 14. fig. 2.)

Effice, having the lip separated by a gutter.

Emarginate, having the margin excavated by a canal.

Epidermis, the outer skin or covering of a shell.

Equilateral, when the anterior and posterior parts of a shell are exactly similar.

Equivalve, (applied to Multivalves), when the two principal valves have the same form, size, and position: (to Bivalves), when the two valves are exactly similar.

Exserted, very thin or slender.

Fissure, a notch or slit, (see plate 32. fig. 1.)

Furrow, a gutter or groove running parallel to the hinge in Bivalves.

Fusiform, spindle-shaped.

Gaping, (in Bivalves), when the valves do not shut close: (in Univalves), when the lower part of the lips is distended.

Gibbosity, a swelling.

Gibbous, swelled.

Glabrous, smooth.

Hinge, the part where the valves are united, and generally furnished with one or more teeth: it is said to be compress. ed, when it is formed of one compressed tooth: lateral, when placed on one side of the shell: reflected, when its edges are folded over the exterior margin: terminal, if situ- 
ated at the extremily of the shell: and truncated, if the beaks of the shell appear to have been transversely cut off, and the teeth of the hinge fixed to this part.

Hispid, covered with hairs, as in the Helix Hispida.

Imbricate, when the surface is covered with scales partially covering each other.

Imperforate, having no umbilicus.

Inequilateral, when the anterior and posterior parts of the shell are dissimilar.

Inequivalve, when the valves are dissimilar.

Involute, without a spire, as in the Patellæ.

Keeled, see Carinated.

Labium, see Lip.

Lenticular, when the valves are round, and diminish in thickness from the centre towards the edges.

Lid, see Operculum.

Ligament, a membranous substance which counects the valves: it is both interior and exterior in the generality of Bivalves.

Linear, when the length of the shell is greater than its breadth, and its form not cylindrical.

Linguiform, tongue-shaped.

Lip, (in Univalves), the sides of the aperture: (in Bivalves), the exterior edge of the valves.

Lunar or Lunate, having a crescent form?

Margin, the edge of the shell: anterior, the space in which the ligament is situated: posterior, the space on the other side of the hinge: superior, the space between the anterior and posterior parts.

Marginate, (in Univalves), having the sides of the shell thickened: (in Bivalves), surrounded with an elevated margin.

Mouth, see Aperture. 
Muscular Impressions, are the marks made by the muscles with which the animal adheres to the shell, as in the Common Oyster:

Obovate, nearly oval.

Obsolete, obliterated.

Obtuse, blunt pointed.

Operculum, (in Multivalves), the stellular valves which shut up the superior orifice: (in Univalves), the part which exactly fits into the aperture and encloses the animal.

Orbicular, forming an entire circle.

Papillary, having the apex rounded.

Papyraceous, of the thinness of paper.

Patulous, gaping.

Pectinated, when the longitudinal ribs on the anterior surface form acute angles with the transverse strix.

Peduncle, a tendinous substance belonging to some of the Multivalves, by means of which they adhere to solid bodies. Pillar, see Columella.

Pillar-lip, that side of the aperture in which the columella is situated.

Pisiform, pea-like.

Plaited, when the columella is toothed, as in Volutes.

Posterior, sce Margin.

Reticulated, like net-work.

Retuse, when the lower whorls are pressed into the body.

Rostrum, see Beak.

Rugose, wrinkled.

Scabrous, rough.

Serrated, toothed like a saw.

Semilunar, like a half-moon. 
Sessile, low, dwarf.

Sinuous, waved.

Sinus, a deep cut, as in the lip of the Murex Babylonius.

Slope, the side from the beaks.

Spinous, having prickles or thorns.

Spire, is formed by the whole of the upper whorls.

Stria, lines, flat or slightly raised: they are called longitudinal, when they run from hinge to margin: transverse, when in a contrary direction: and concentric, when they form segments of circles.

Subcordate, approaching the form of a heart.

Subpellucid, not quite clear.

Subulate, tapering.

Superior, see Margin.

Suture, a toothed joint.

Syphon, a prolonged tube running through the partitions of chambered shells.

Teeth, (in Univalves), angular plaits, as on the pillar lip of Volutes: (in Bivalves), pointed protuberances within the hinge, by which the valves are united. They are called: alter: nate, when the teeth of one valve are received betwcen the teeth of the other valve: articulated, when the tooth is received into a corresponding cavity in the opposite valve: cardinal, the central tooth or teeth of the hinge: compressed, when flattened: erect, perpendicular to the plane of the hinge: forked, having the point divided into two: longitudinal, when it extends along the margin.

Tubercle, a protuberance or knob.

Tuberculated, having elevations resembling warts.

Tubular, (applied to Multivalves), when the greater part of the shell is cylindrical.

Turbinated, when the belly of the shell is large in proportion to the spire, which seems to proceed from the centre. 
Valves, the different pieces which compose the shell.

Varix, Varices, longitudinal elevations or ribs, formed by the junction of the different additions the shell has received.

Ventricose, bellied.

Vermiform, having the form of worms.

Vertex, the top or point of a shell.

Umbilicated, having a hole in the base of the pillar.

$\boldsymbol{U} \boldsymbol{m b}$, the summit.

Undulated, waved.

Whorl, a spiral convolution. 
LONDON:

PRINTED BY W. M'DOWALL, PEMEERTON ROW, GOUGH SQUARE. 


\title{
FOLLOWING WORKS
}

\author{
IISE BEEN \\ RECENTLY PUBLISHED,
}

BY MESSRS. LONGMAN AND CO. PATERNOSTLR-ROW;

AND

BY THE AUTHOR, MR. MAWE, 149, STRAND.

1. FAMILIAR LESSONS on MINERALOGY and GEOLOGY, with numerous coloured Plates, price 7s. The Descriptions of Minerals and Rocks are accompanied with References to the Plates, and illustrated in an easy and agreeable Manner, so that the Learner may become immediately acquainted with the Characters of the various Substances to which his Attention is directed. Fifth Edition.

2. NEW DESCRIPTIYE CATALOGUE of MINERAIS, with Diagrass of their simple Forms, after the late Professor Clarke's System. Fourth Edition, price 7s, entirely re-written, on a Plan calculated to facilitate the Arrangement of Collections.

3. INSTRUCTIONS for the MANAGEMENT of the BLONPIPE, ACIDS, and CHEMICAL TESTS; explaining the best Mlode of employing them in the Analysis of Minerals. With an Appendis from Berzelius. Third Edition. Embellisbed by an explanatory Frontispiece, price 4s.

4. The SHELL-COLLECTUR'S PILOT, or VOYAGER'S COMPANION, with an elegant coloured Frontispice, and Plate of Insects. This little Work is peculiarly adapted for Voyagers in general, pointing out the Places where the best Shells were found in a Voyage round the World, and during a period of Sixteen Years which the Author passed at Sea. Price 5s. Third Edition,

6. TRAVELS in the INTERIOR of BRAZIL; with Notices on its Climate, Natural Productions, Agriculture, Commerce, Population, Manners, and Customs: and a particular Account of the Gold and Diamond Districts. Including a Voyage to the Rio de la Plate. Second Editiun, illustrated with Coloured Plates and a Map, 8vo. price 18s. bds.

7. TREATISE on DIAMIONDS and PRECIOUS STONES; their History, Natural and Commercial. With coloured Frontispiece, and numerous Plates, including the celebrated Diamonds in Europe, and coloured fac simile of the Blue Diamond, lately purchased by His Majesty. Just Published, Sccond Edilion. Price
15s. 


\section{MINERALOGY AND GEOLOGY.}

Mrnerats, Select Specimens, the greatest Variety, price marked on each.

Collectrons, calculated for Learners, at various prices, from Three Guineas to Twenty; classed and arranged according to the New Descriptive Catalngue.

Colrectrons, more extensive, from Twenty to One or Two Hundred Guineas.

** Practical experiments will be shewn, and every information given to assist the learner in his pursuits.

Grological Collectrons, censisting of Specimens belonging to the Primitive, Transition, Secondary, Floctz Formations, \&c. with the Alluvium from the Gold Mines in Brazil, shewing the nature of the soil in which Gold and Diamonds are found, from Two to Ten Guineas.

Geologrcal Coliections, from Frihurg, consisting of from 150 to 200 Specimens.

Cifmical Tests for ascertaining Minerals.

Blow-Pipes, One Shilling each. Fragments for the Blow-Pipe or Microscope, A trate Mortars, Stcel do., Platiad Forceps and Spoons, Mlagnets, Llectrometers, Knives, Glass 'T'ubes, Returts, Hammers of various sizes and forms: and whatever is requisite to the Mineralogist and Geolugist.

Fluor, Strontian, Barytes, Molybdena, Uranium, \&c. for Clsemical purposes.

Lapidaries' Apparatus, complete, for cutting, slitting, and polishing hard stones. With tools for polishing soft substances, as Sir elLs, \&ic.

Amatesr Lapidary, or, a Practical Description of the use of the Lapidaries' Apparatus, with coloured Frontispiece.

Gentlemen abroad, desirous of exchanging Shells or Minerals, Mr. M. will be happy to correspond with them, and receive consignments.

\section{SHELIS.}

As extensive variety of the finest speeimens, price marked on each.

Cozlections of Sirelis for students, shewing the Genera, at various prices, from Thiee Guineas to Twenty, as the Specimens are more or less Numerous and Select.

Secondary Shells, a great variety, f:um One to Three Stillings each. Inferior Shells for Grottues. 


\section{CATIIION}

PLI.

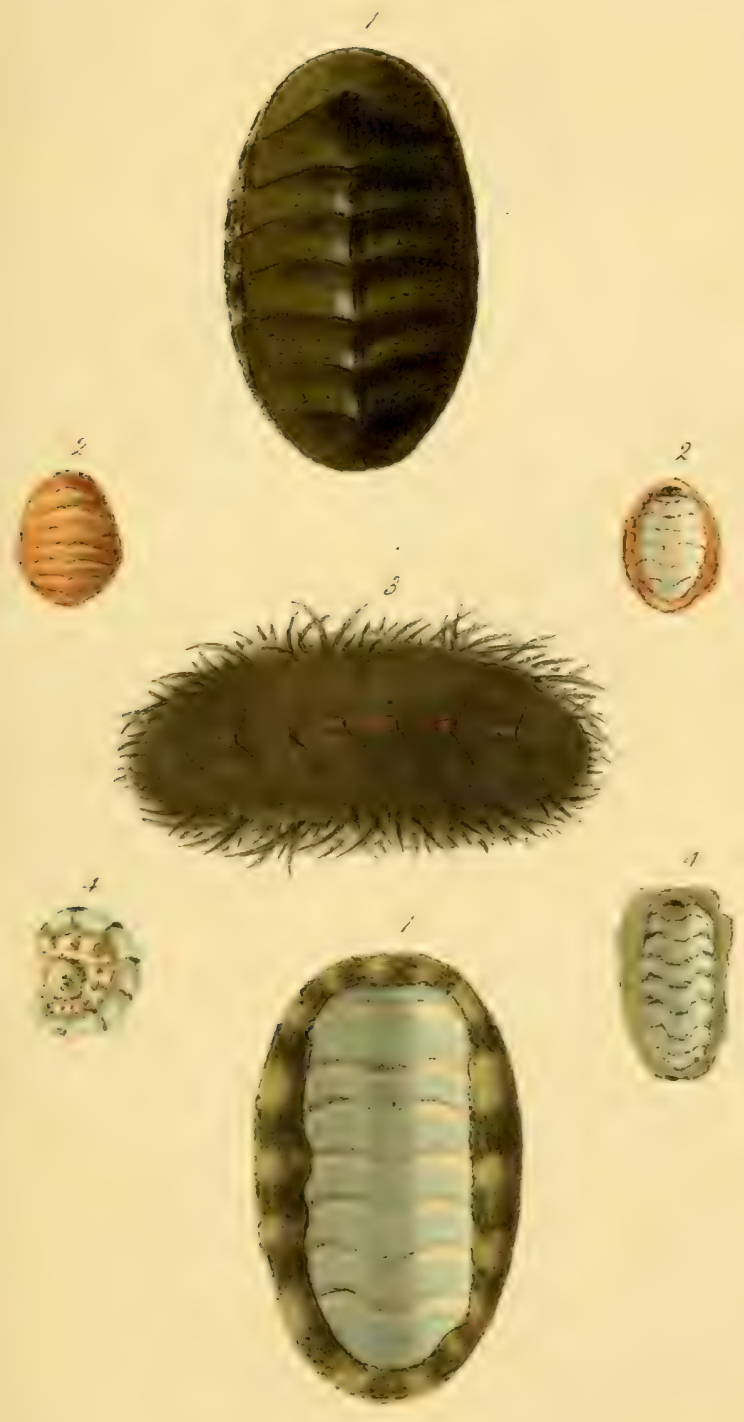





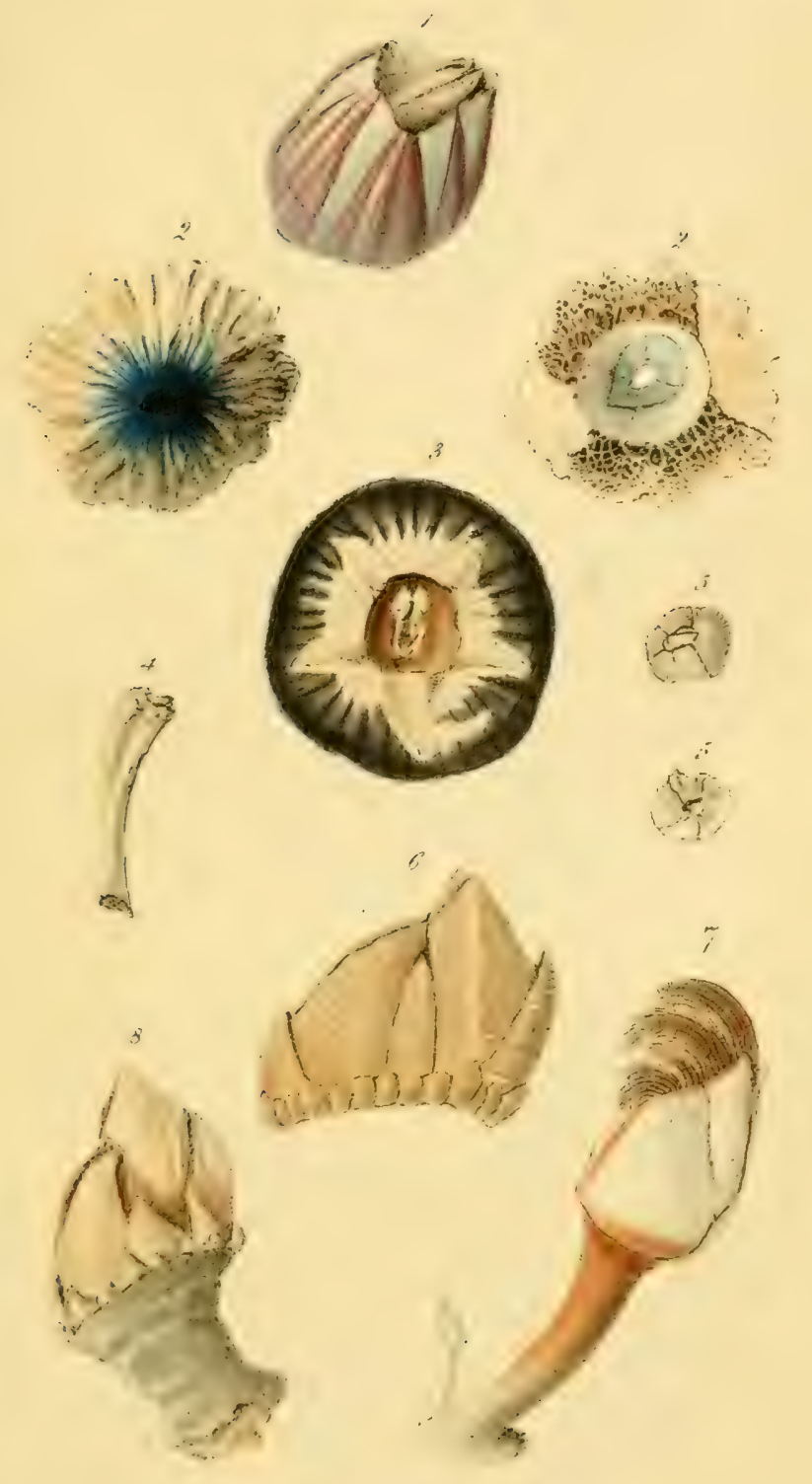





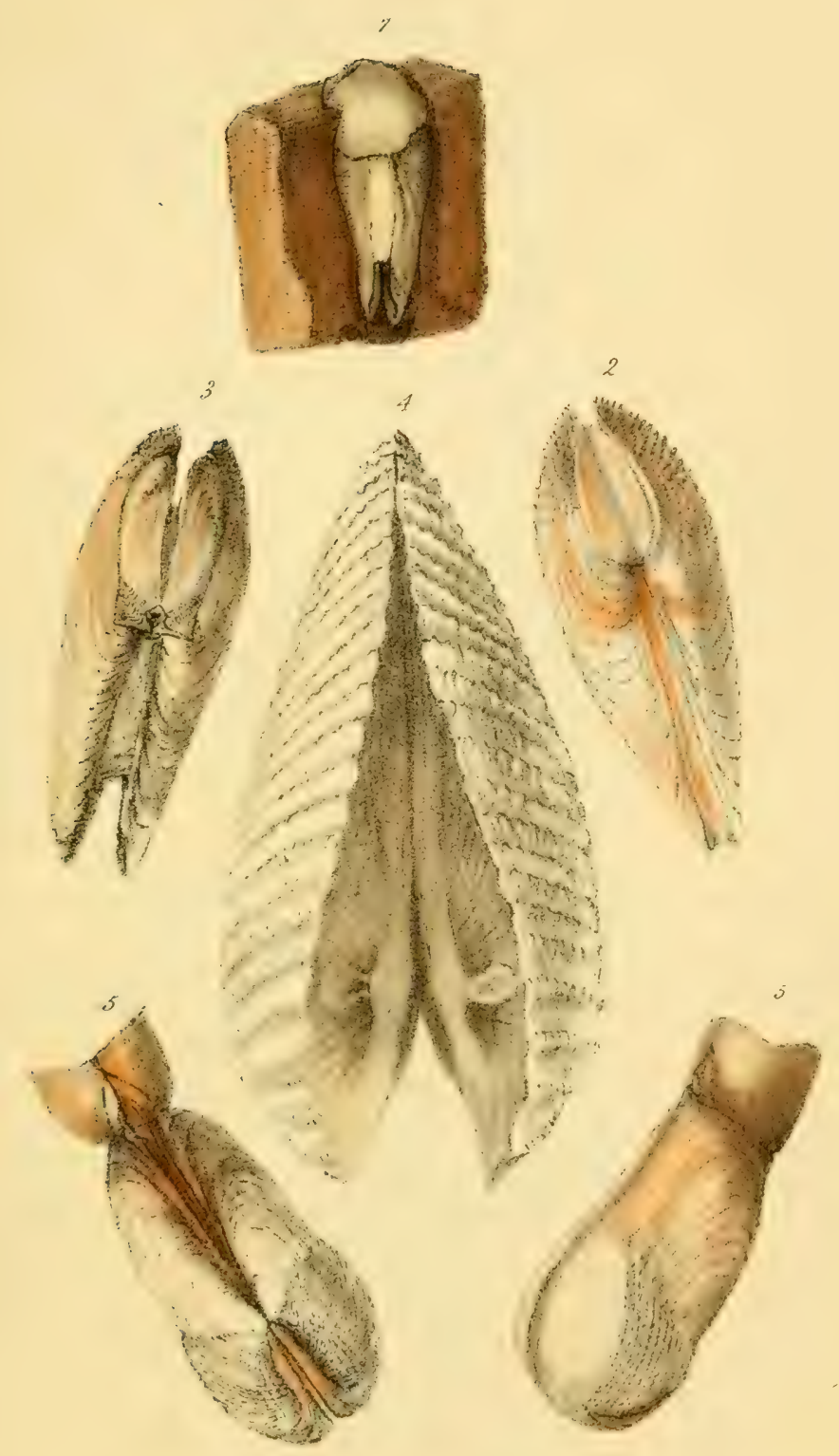





\section{MIIA}

$27 \cdot 1$
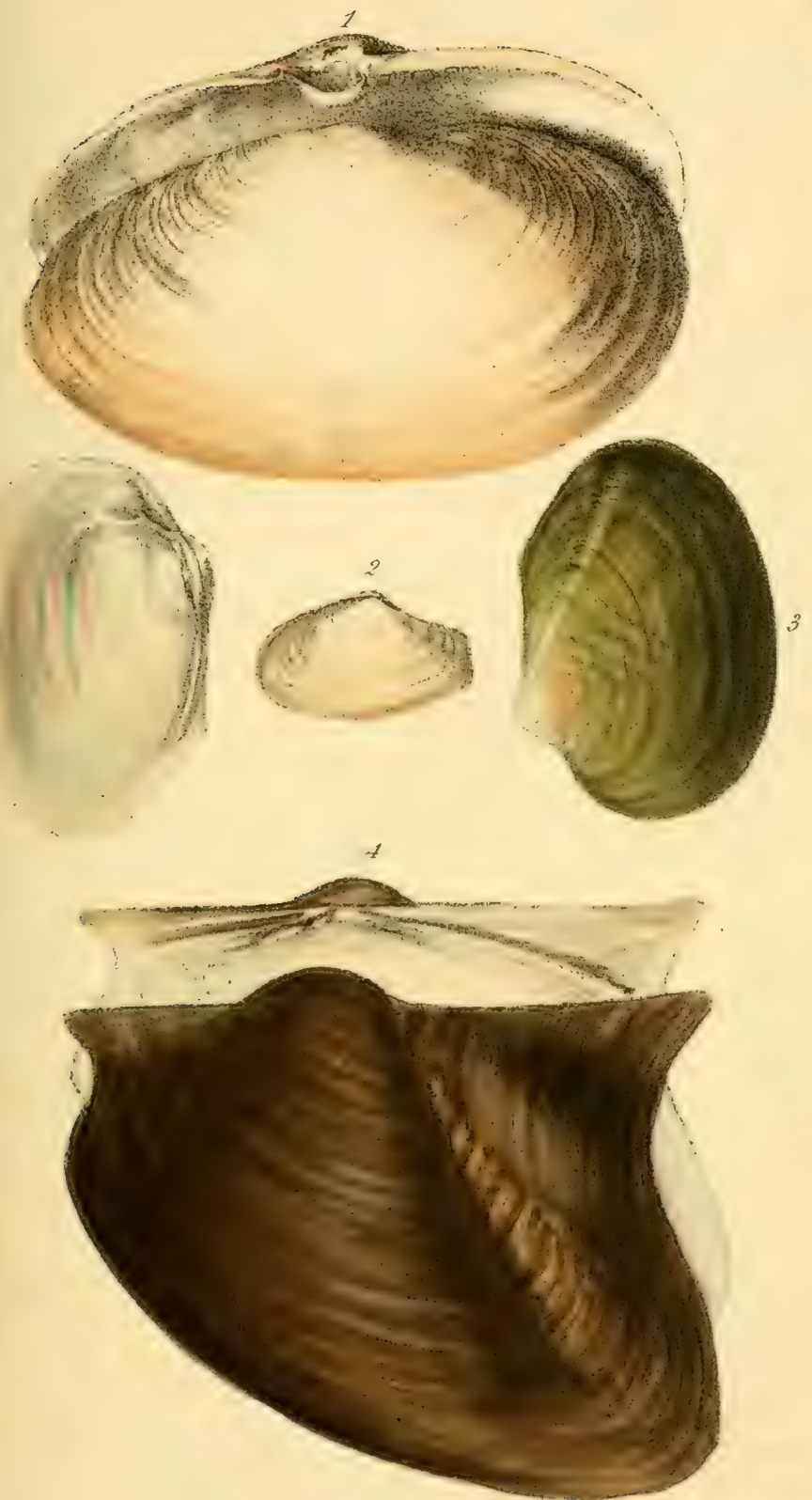

E.4. Crouch Lithoes.

Drinmel Row'rey \& Forlter 

PU.

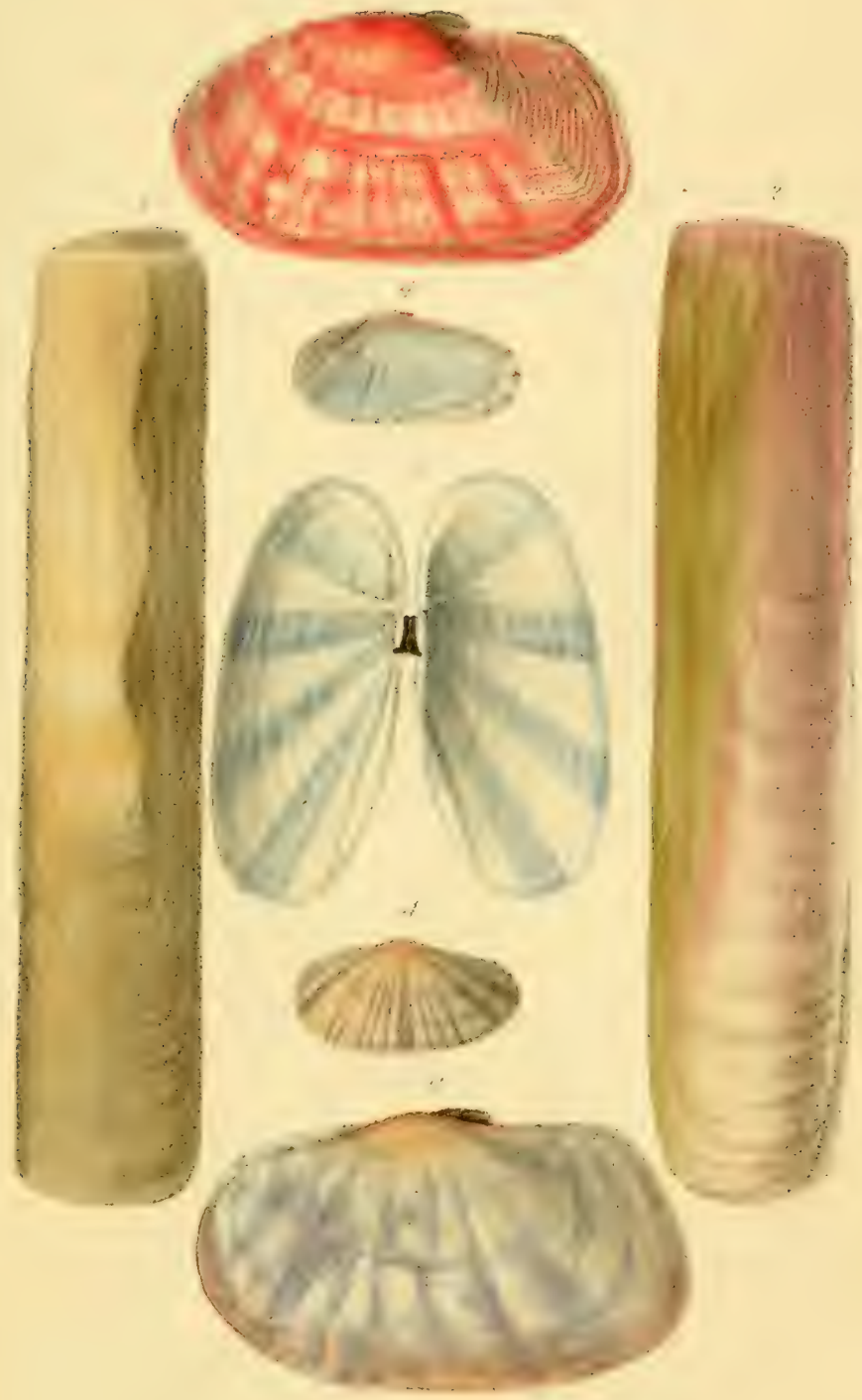





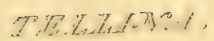

PV. 6 .
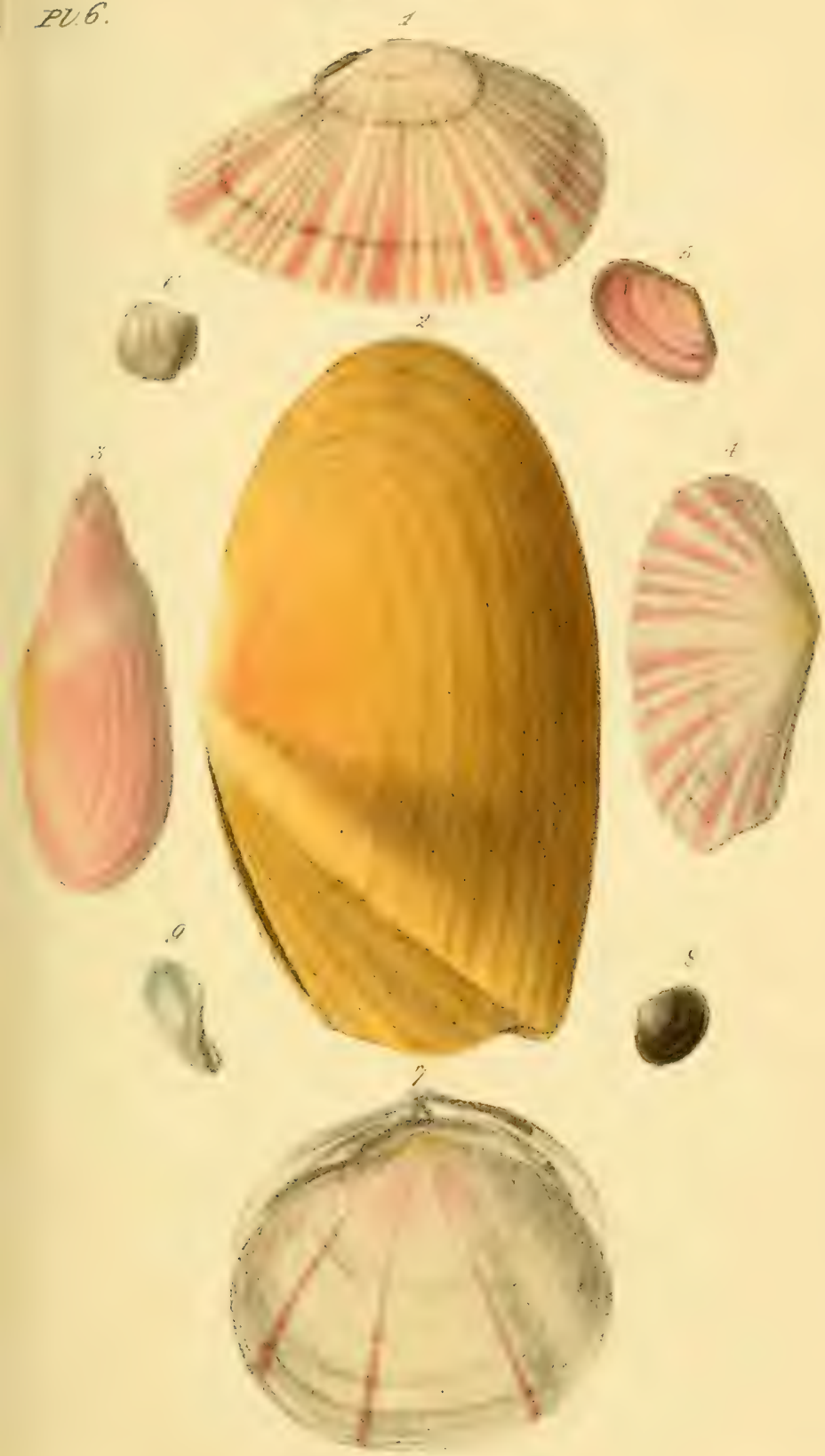


MAACTRRA.

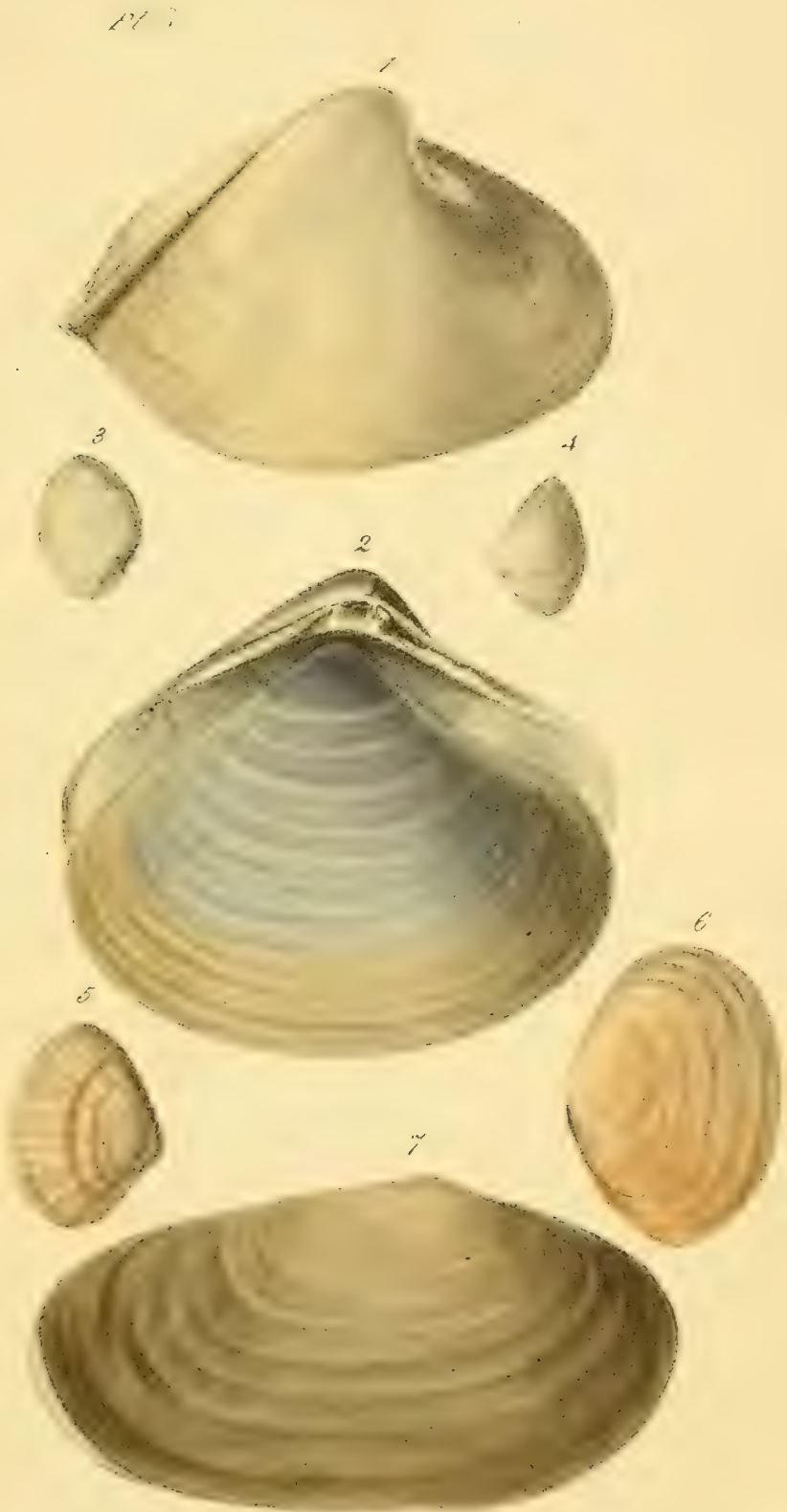



DO. $121 \pi^{\circ}$

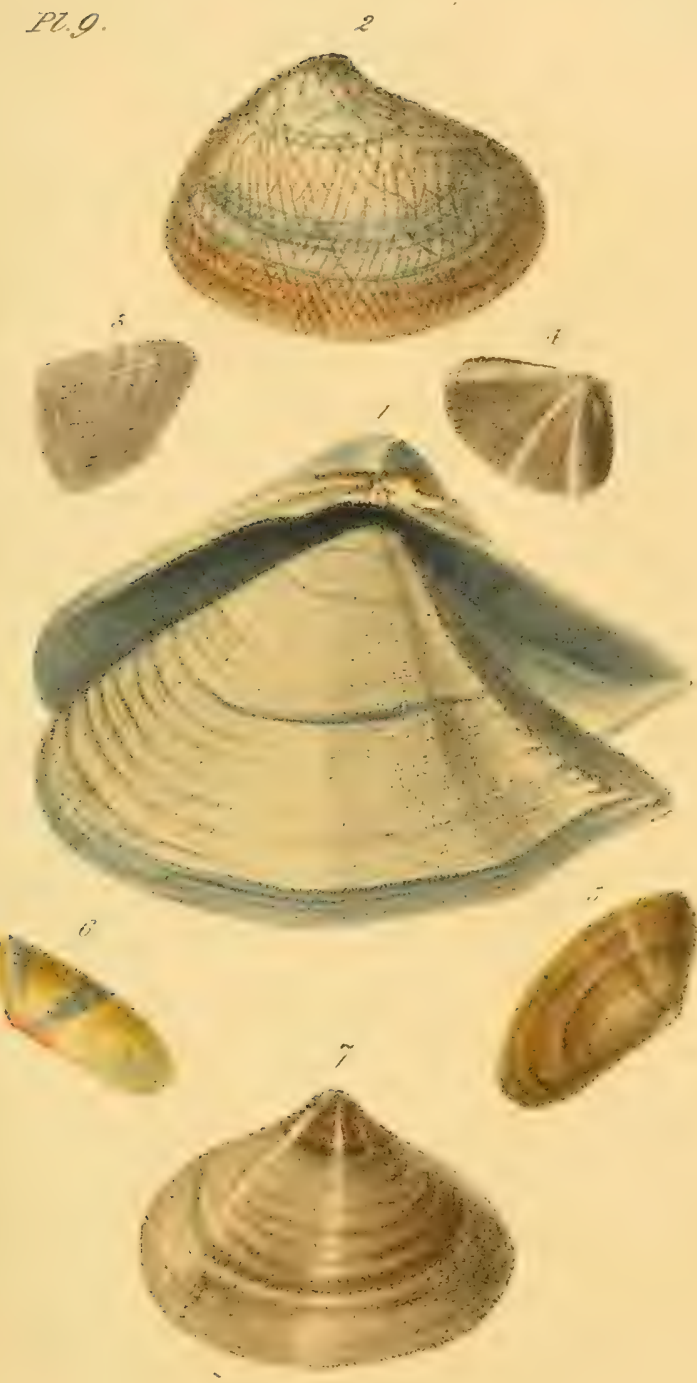




UPONDIZZW

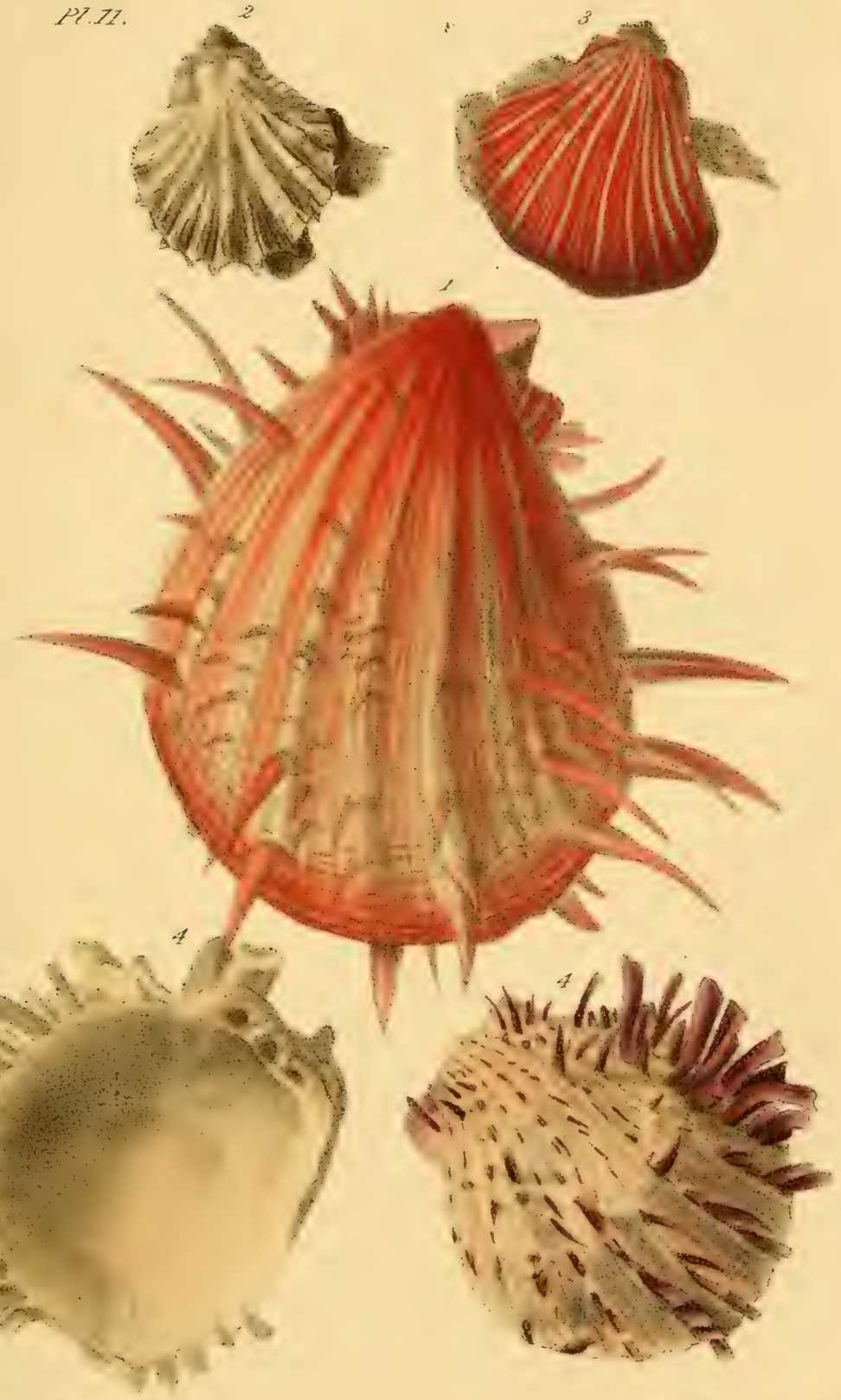



CHAANAA.

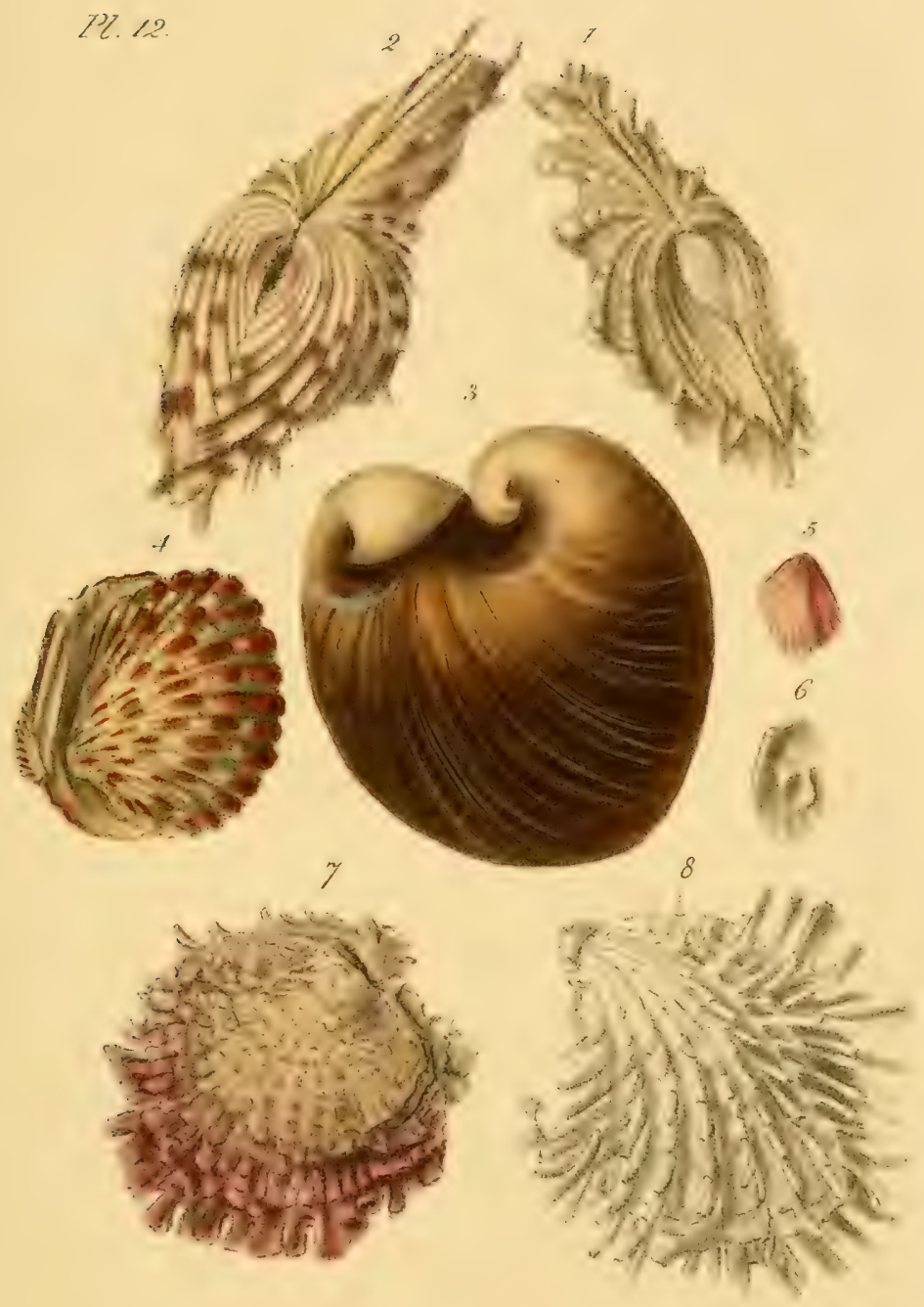

E. A. Crouch Lithog:

Perinted bu Rowney \&porfer

By F.WATI: 7tg Strand. 

PQ13. 7
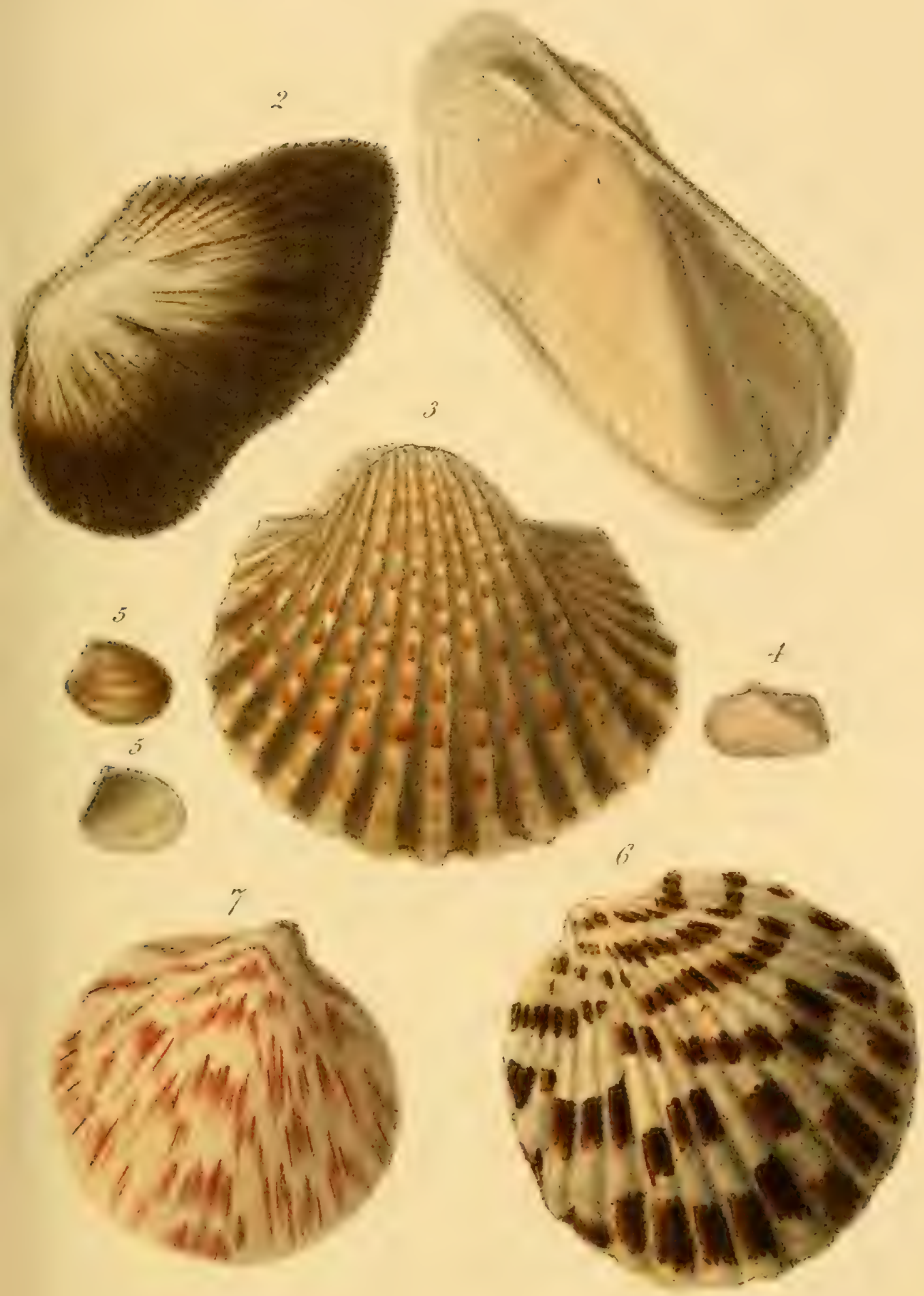

E.A. CronctuZithos 



\section{D.FIRTIA.}
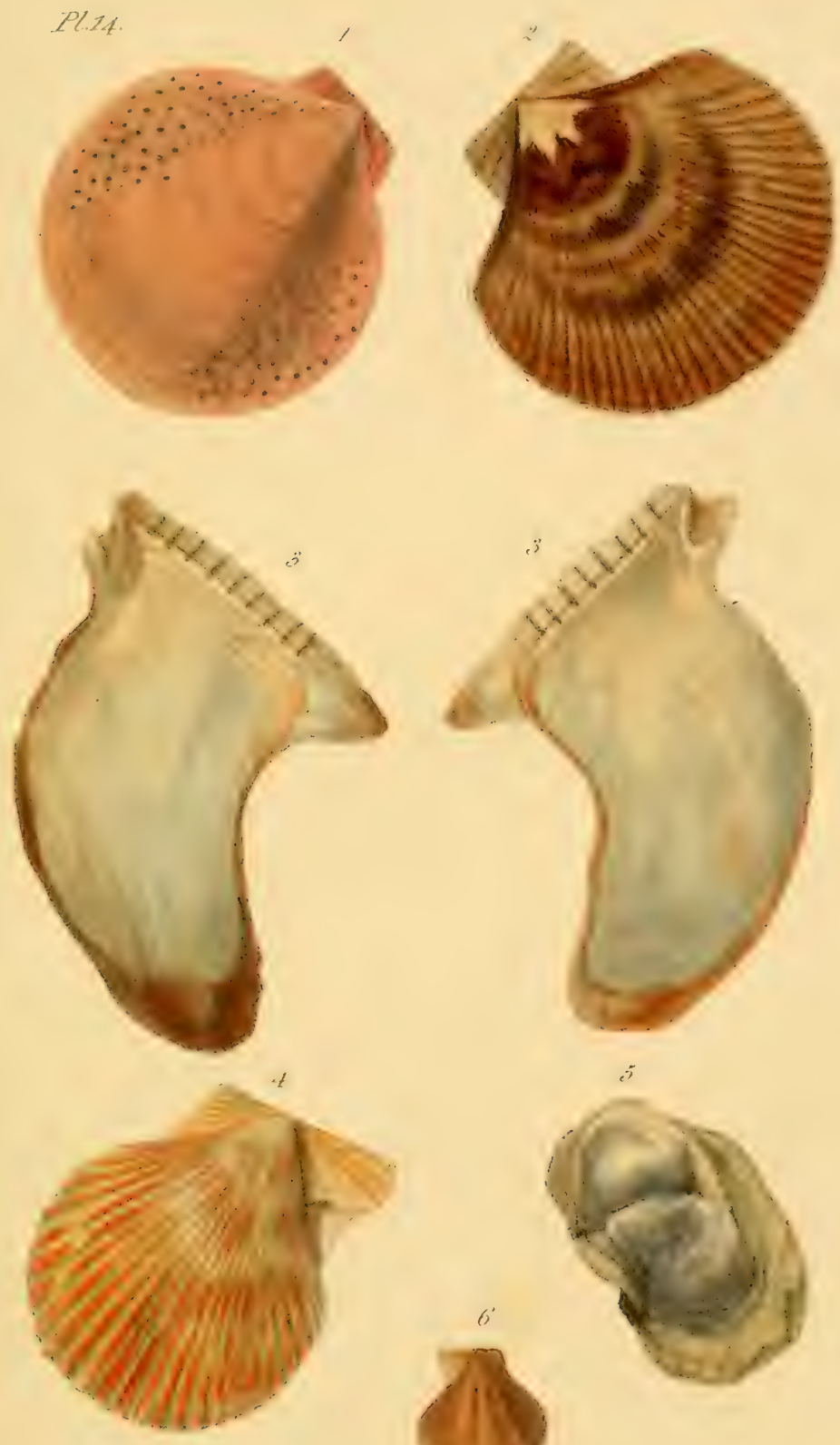

E. A. Crouch Zithos.

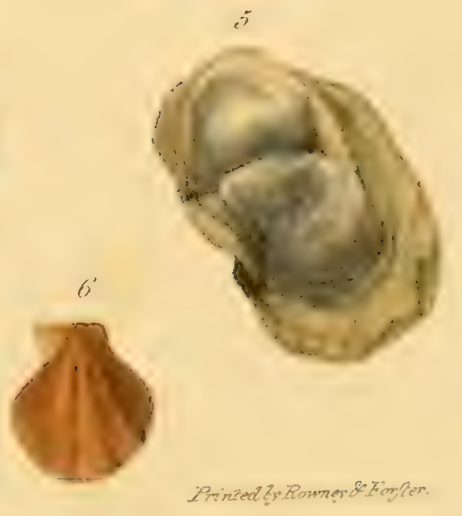

BJ T. ALAWE YAO Strand. 

At MTOAiItAil.

PI 15.
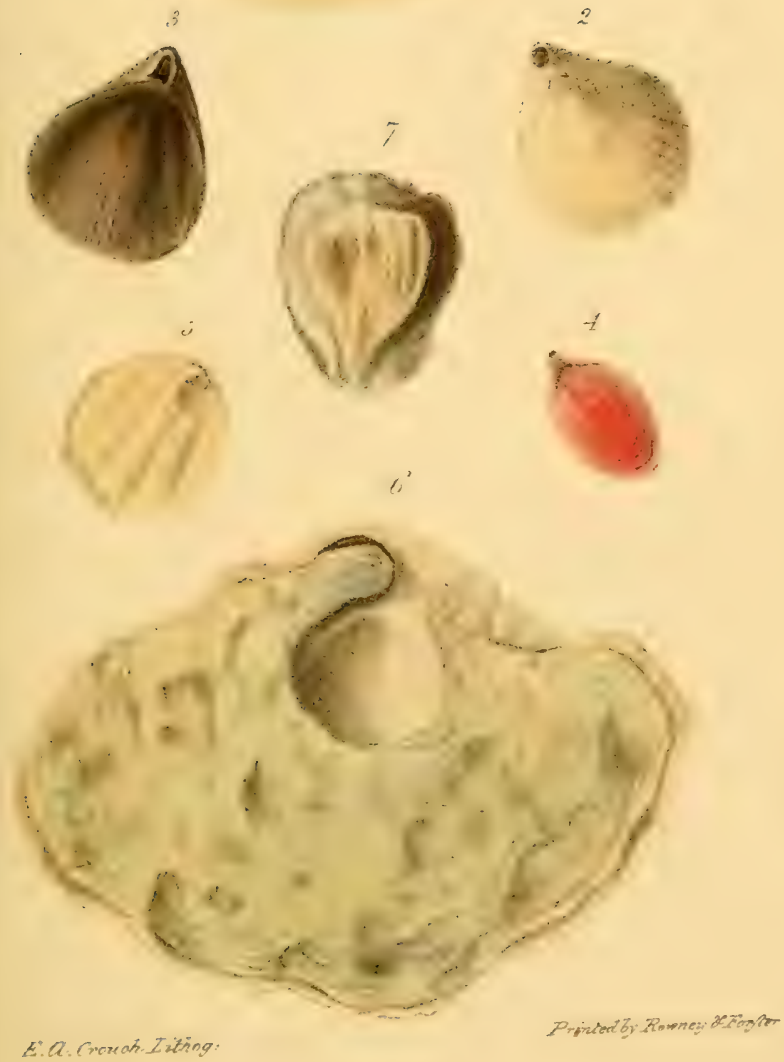

By. T.NAIIE 149 efrand. 



\section{AITIYIITVS.}
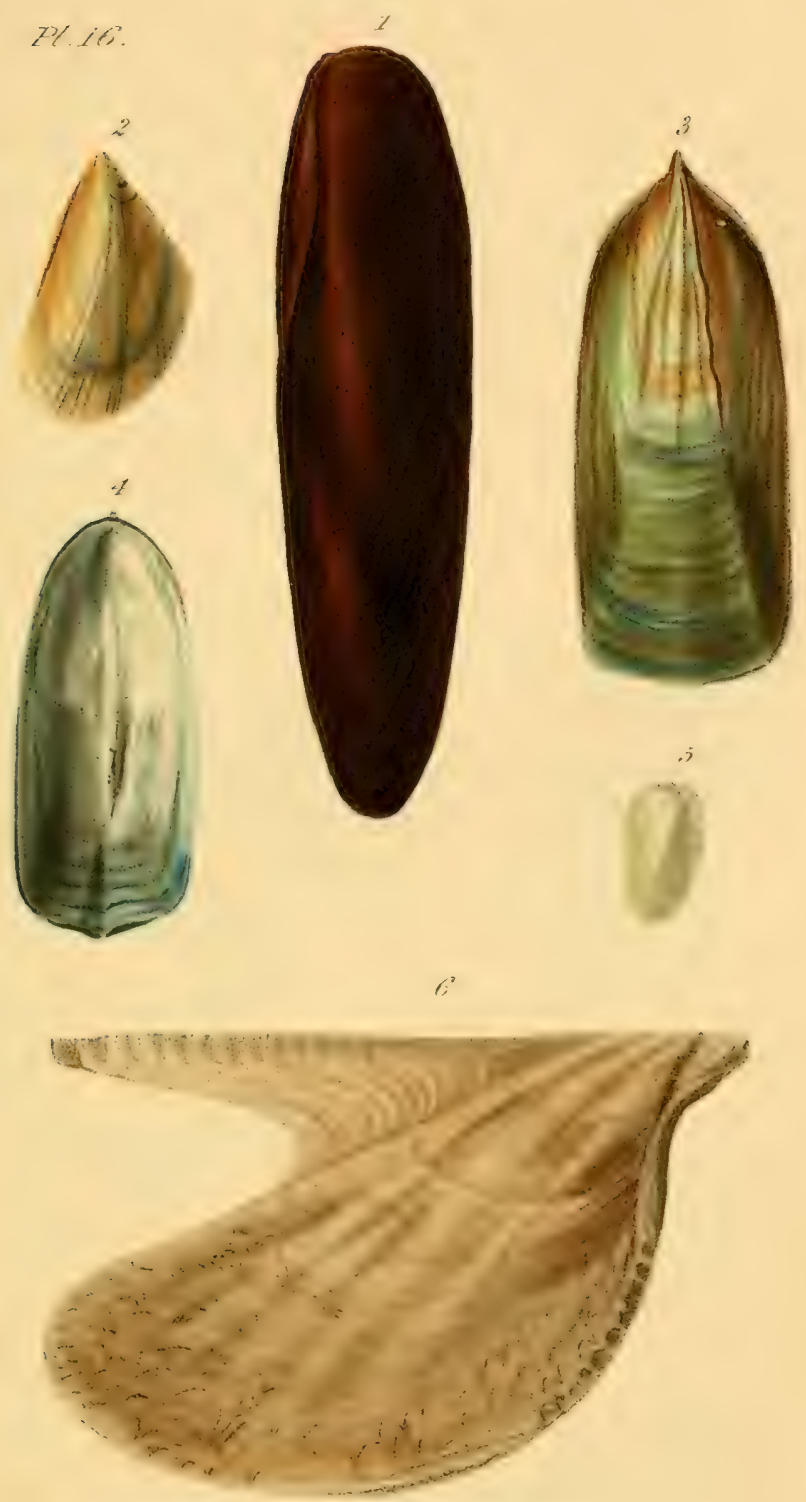

Z. A.Croush Lizkog: Printedzy Rowng \&fojper

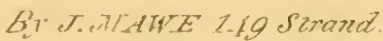



PPINDA.

IY.Y.

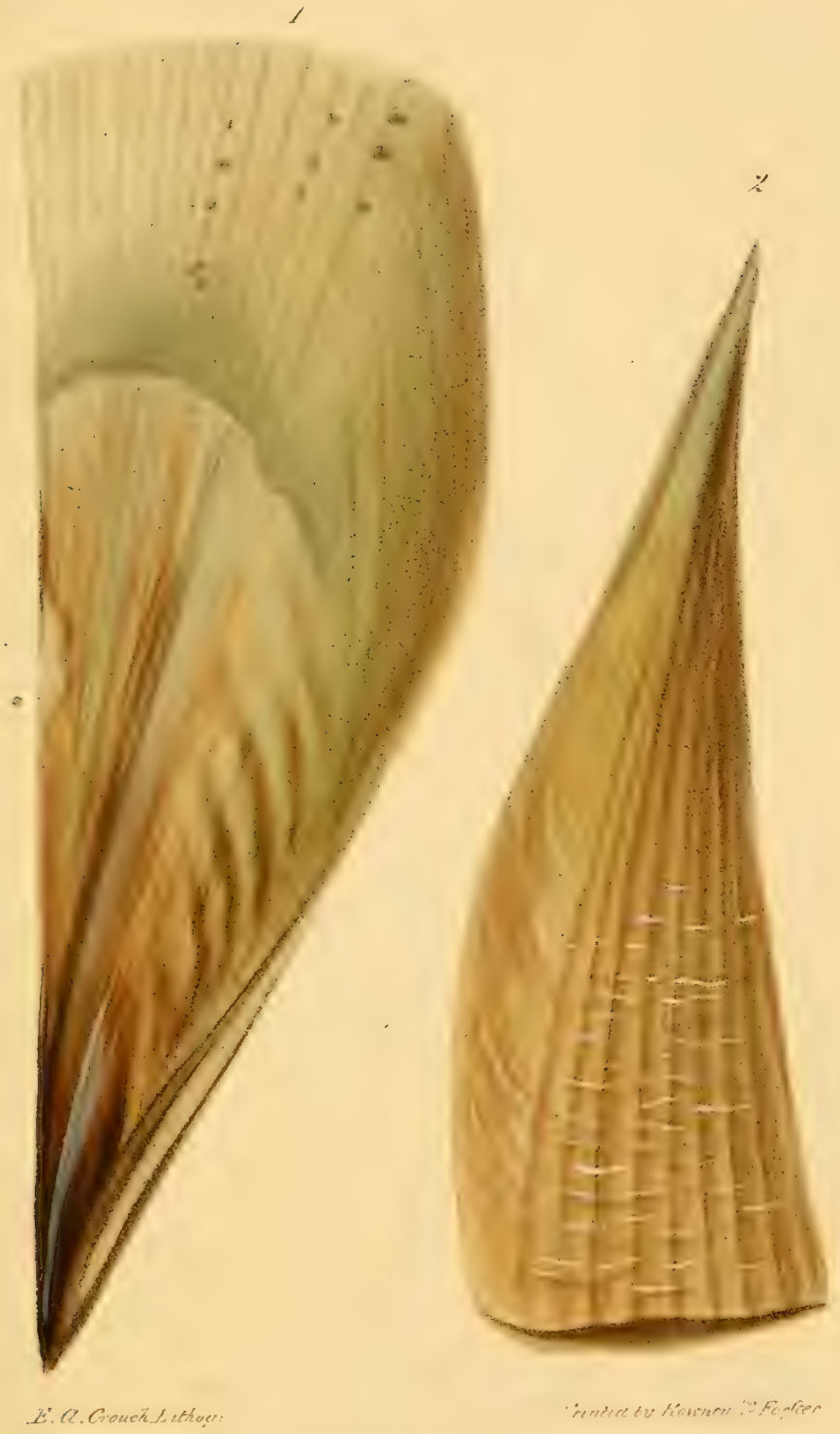

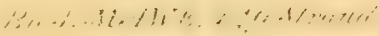



\&.

ARGONAITIAL.

I\%.

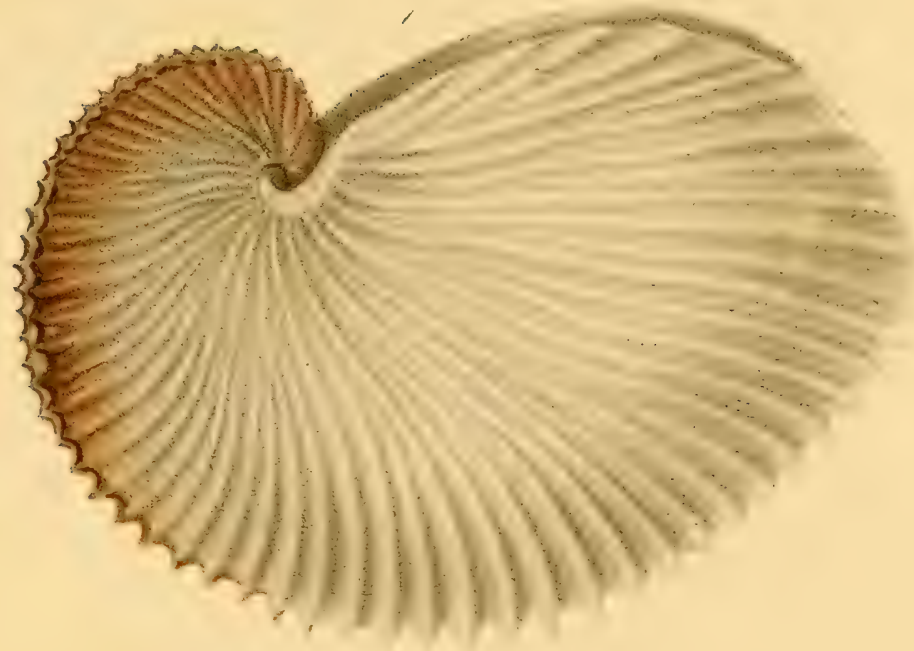

$\because$

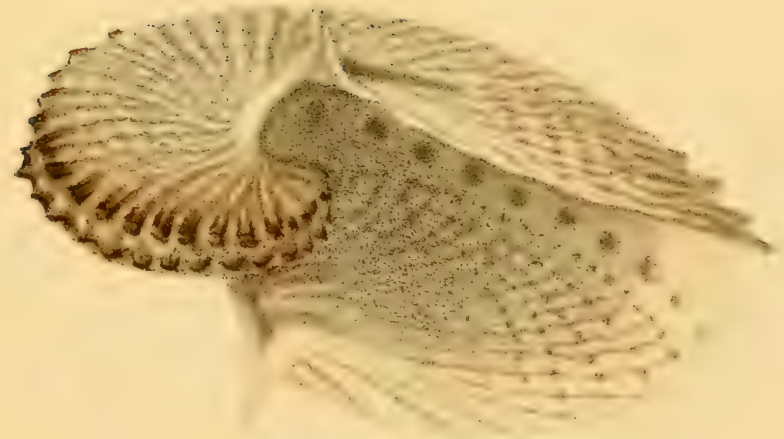

E. A. Cronot tietsog.

Thinked bu Remongy BeForper.

By T.MLWE, 140 Strand. 

$P \%$

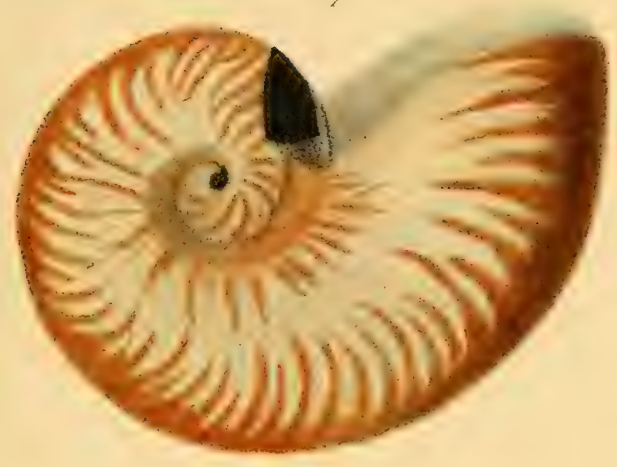

;

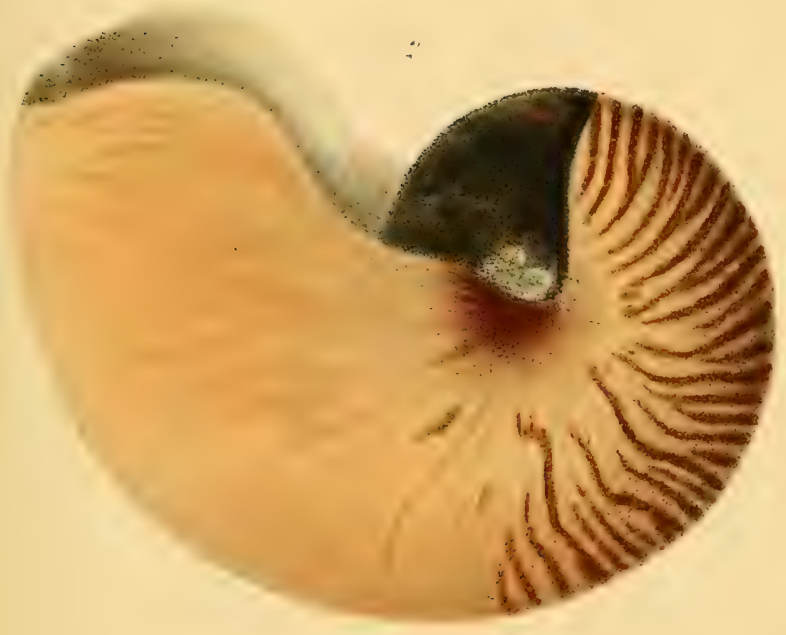





$$
\text { (") }
$$
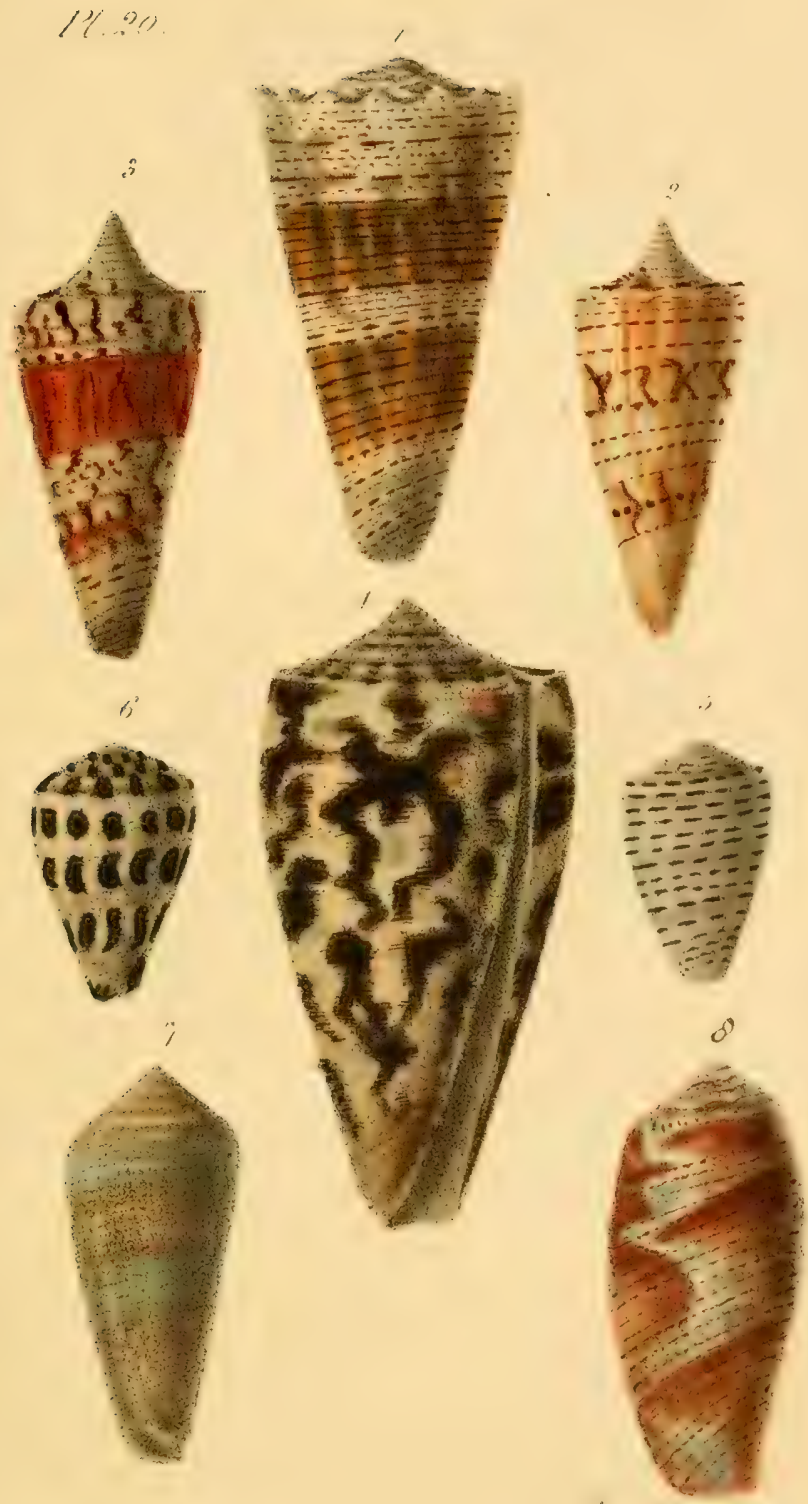


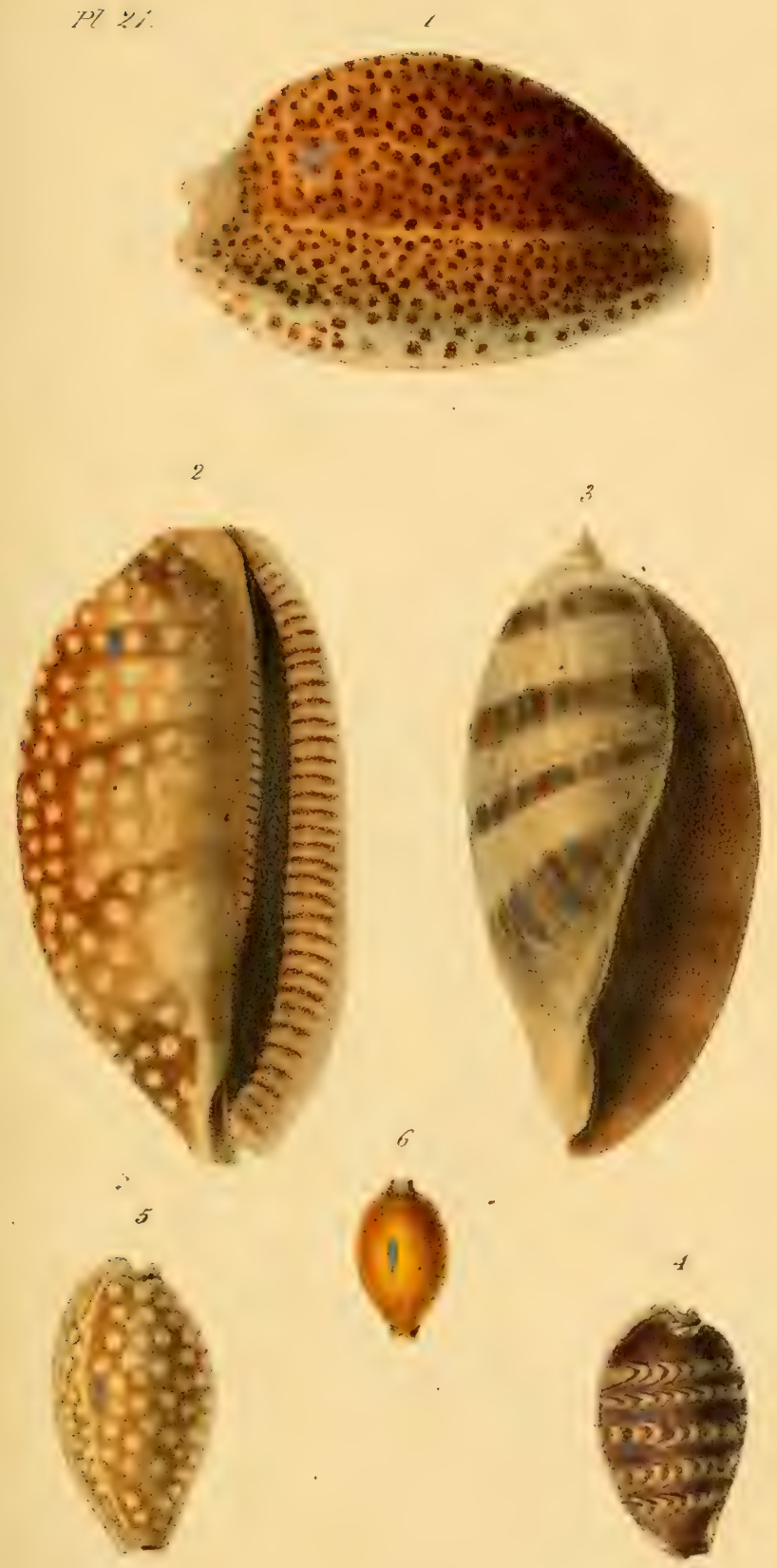

I. A. Crouch titheg

Irinted'bufiowny STorthor.

By J. WAWE, 149 Strand. 



\section{BDTULA}

PY.22.
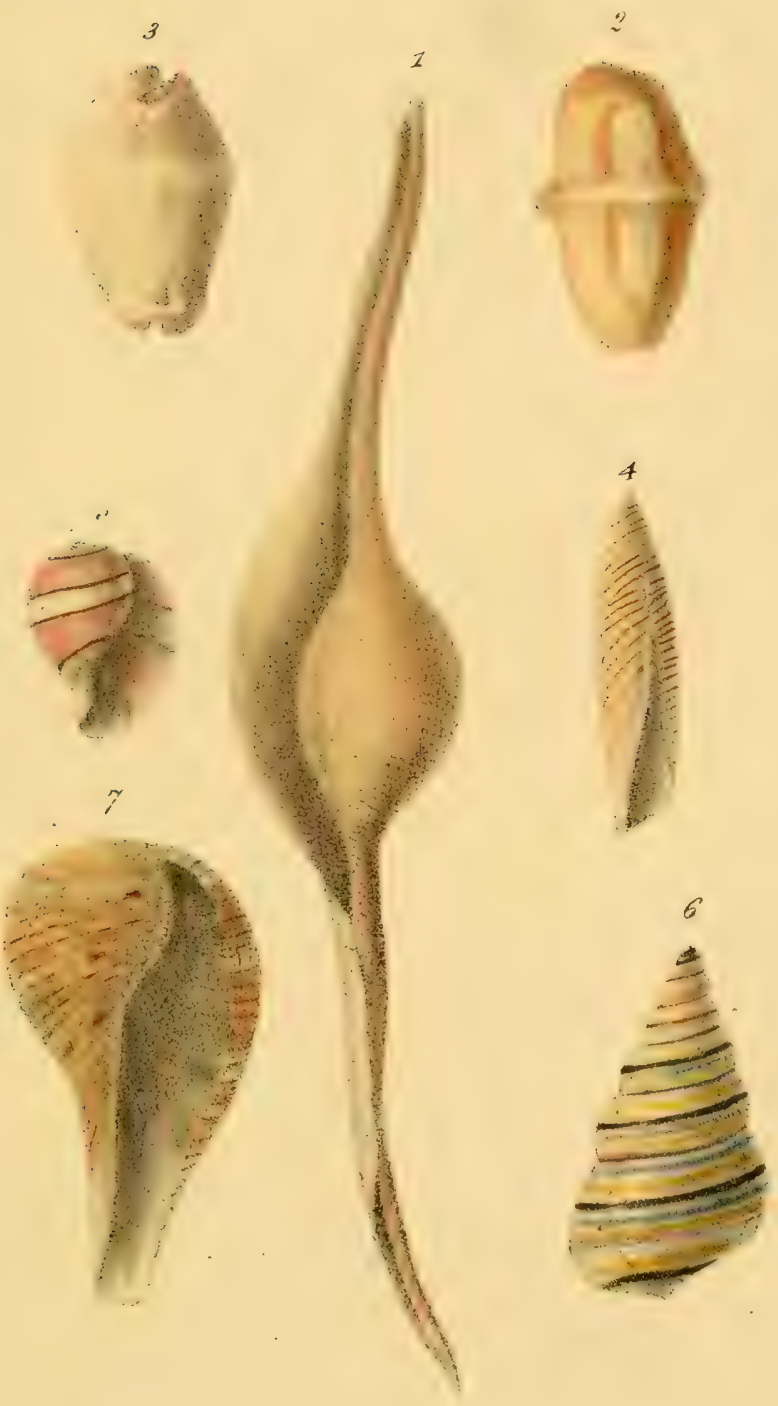

Li. A. Crouch Zithog. 

VYOZTYTA.
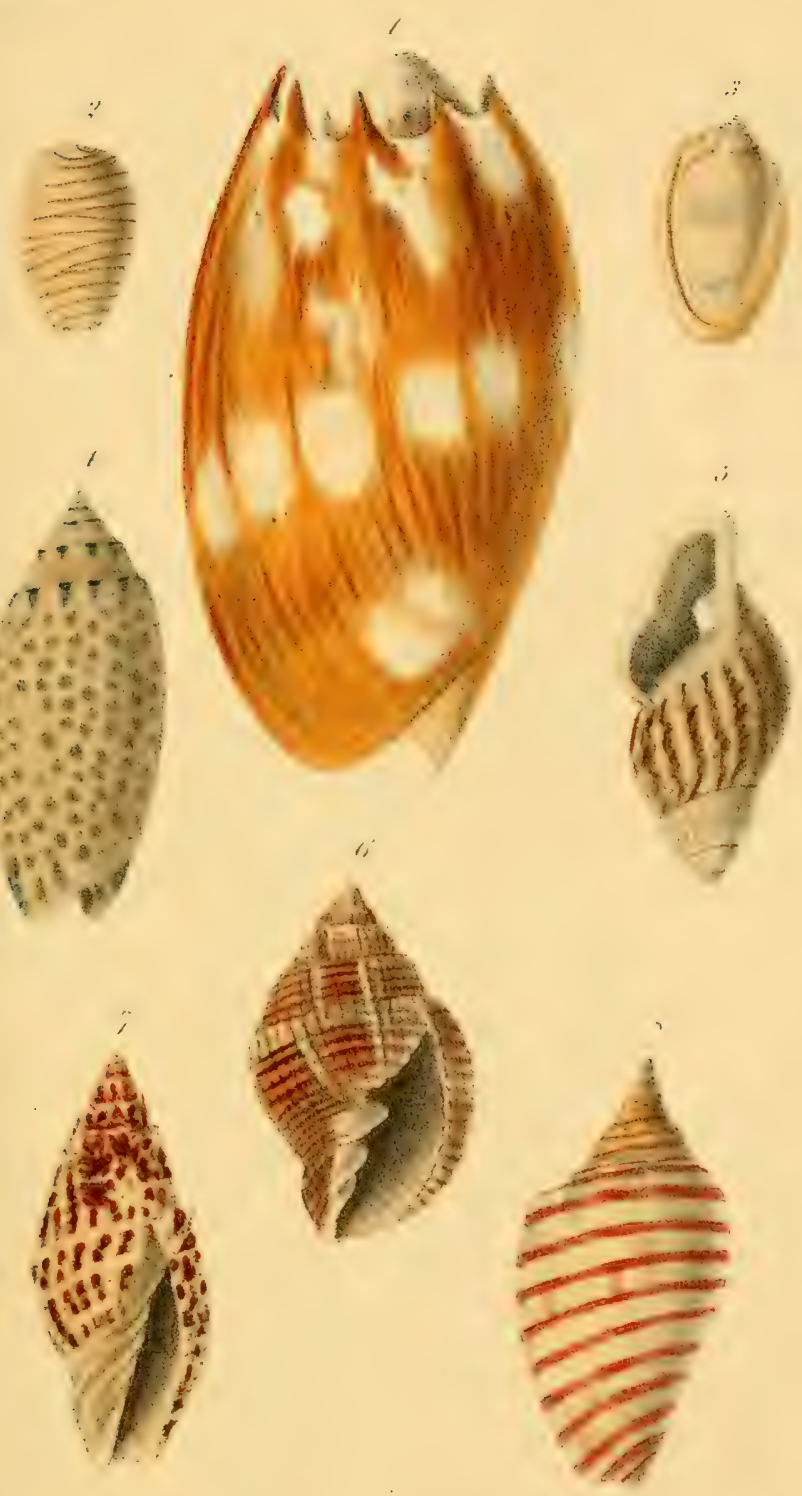

PI: 21
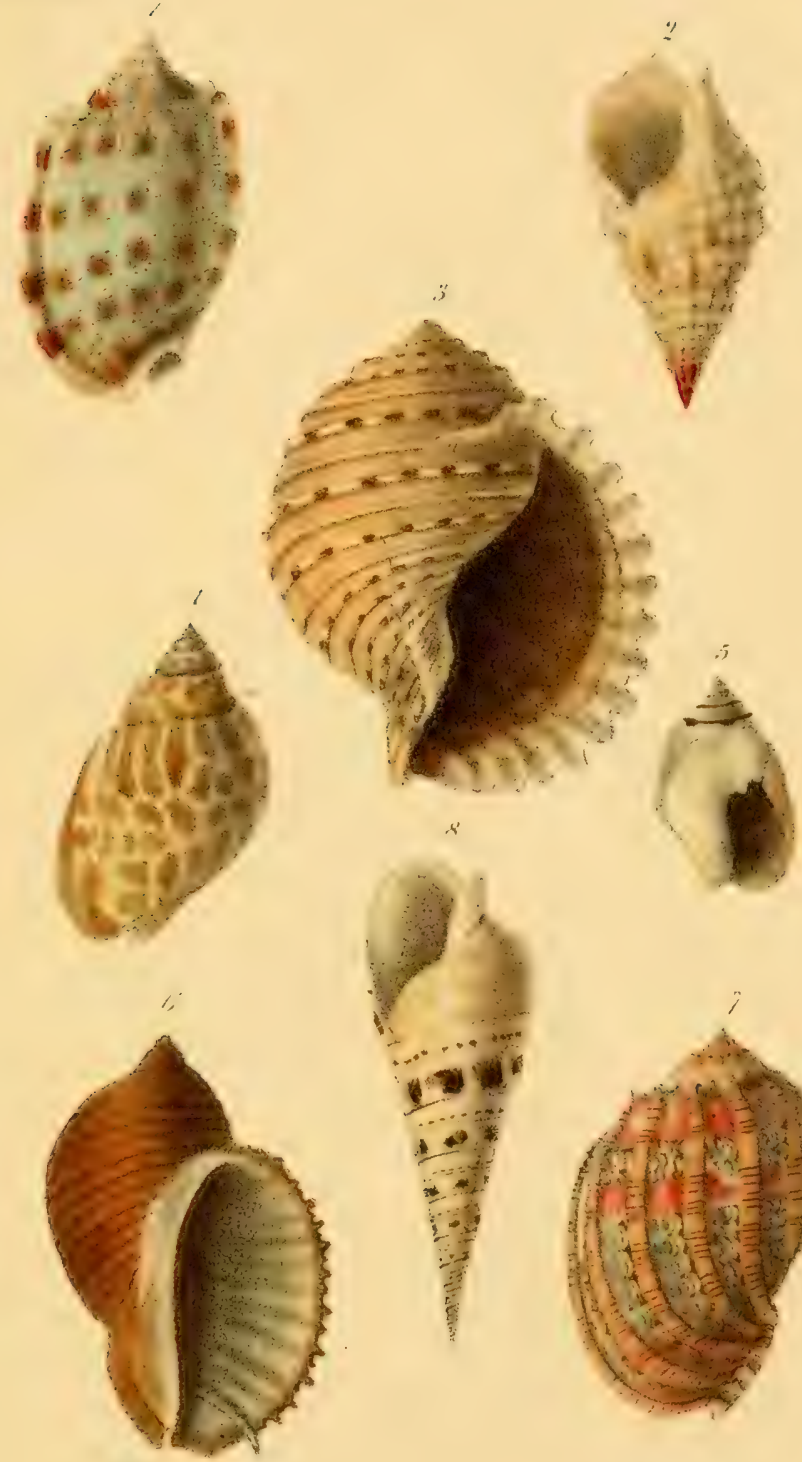

$\because *$

is

$\because \frac{1}{2}$

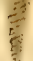

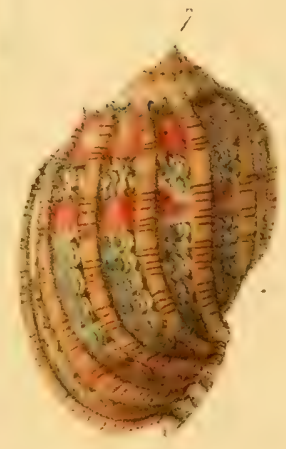






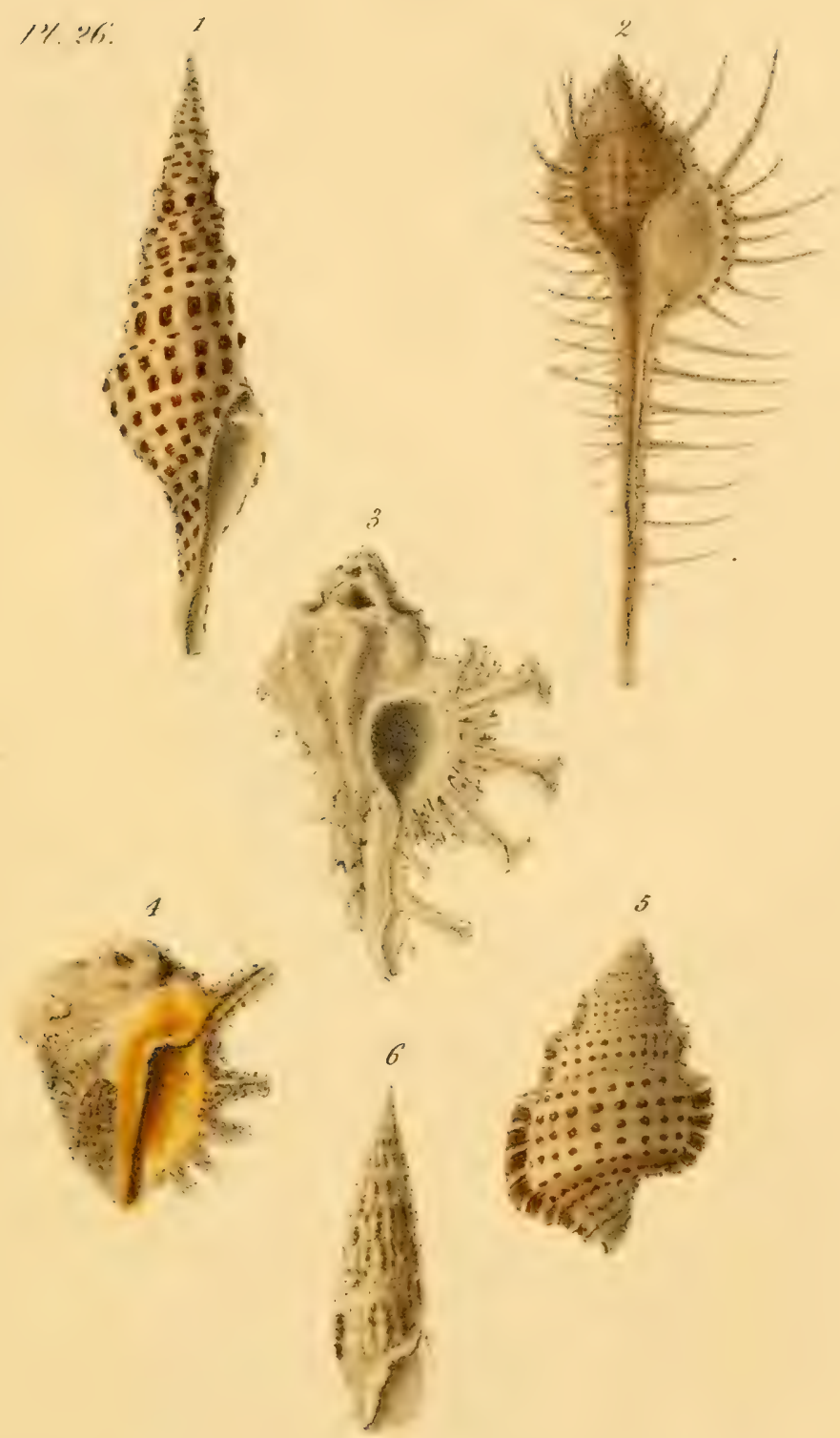



TRORATES

$T P: \because$
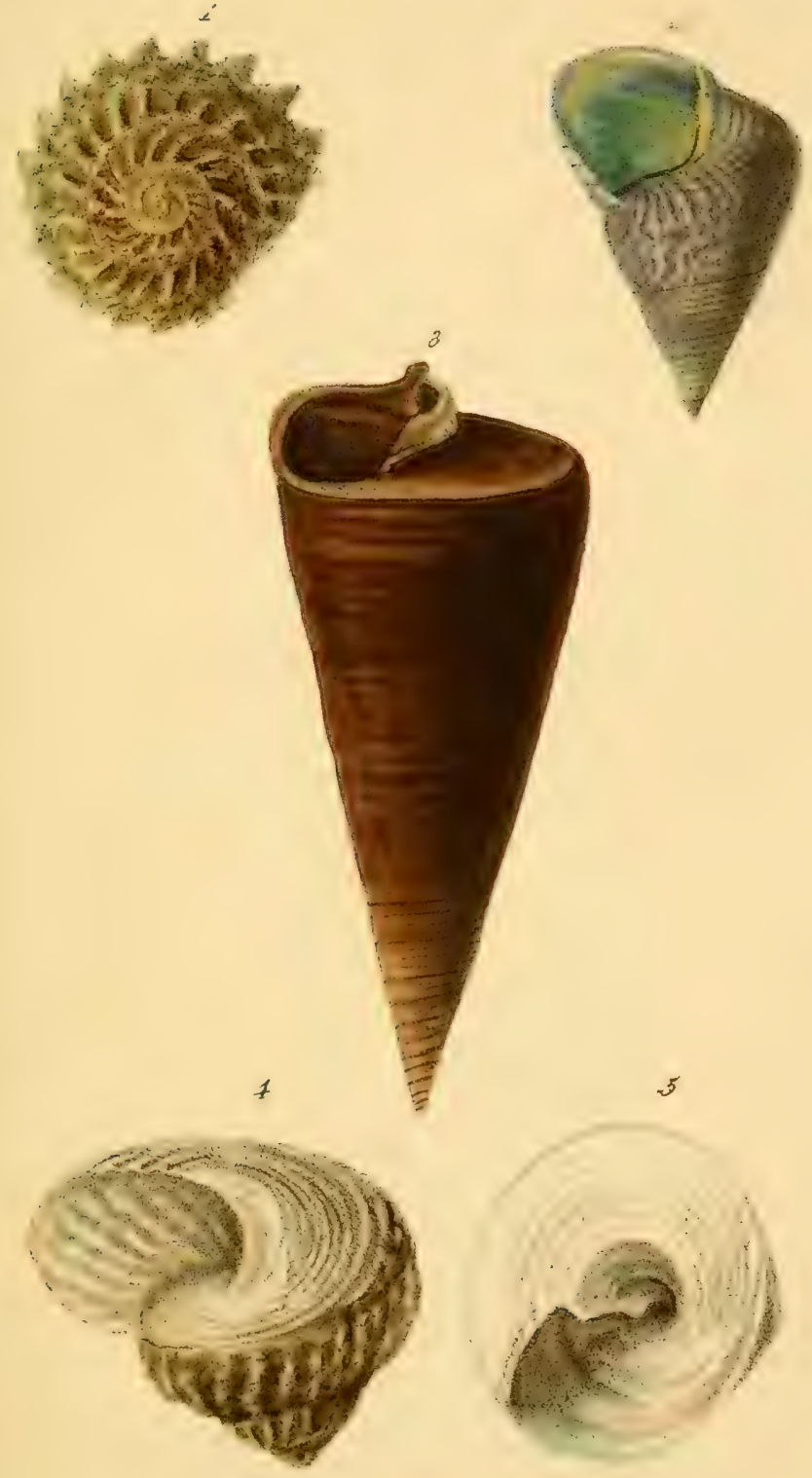

TEXIBO

138.
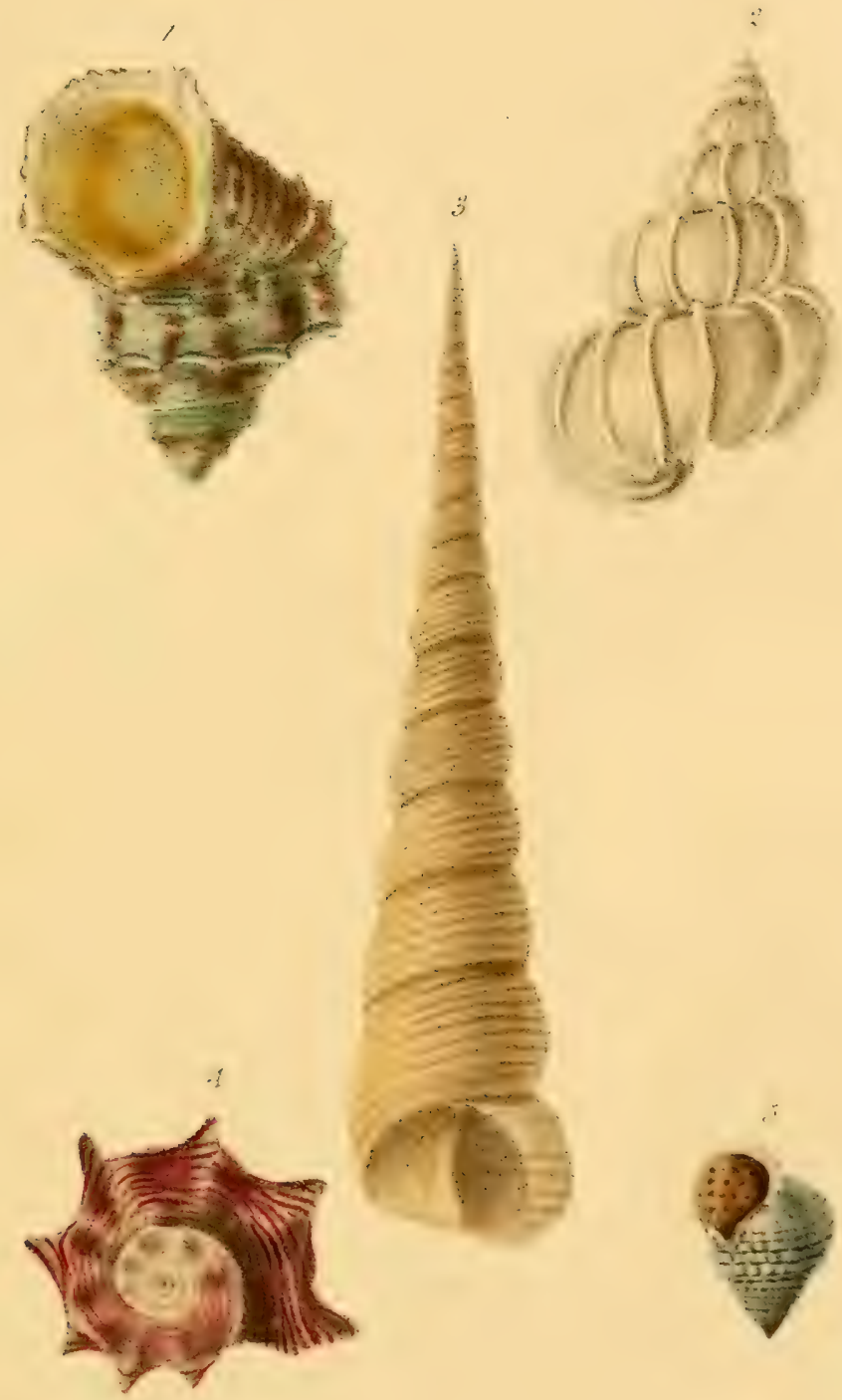

El Ca Crinch Zithog:

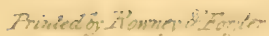

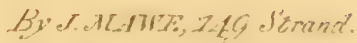





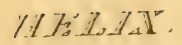

$17 \%$

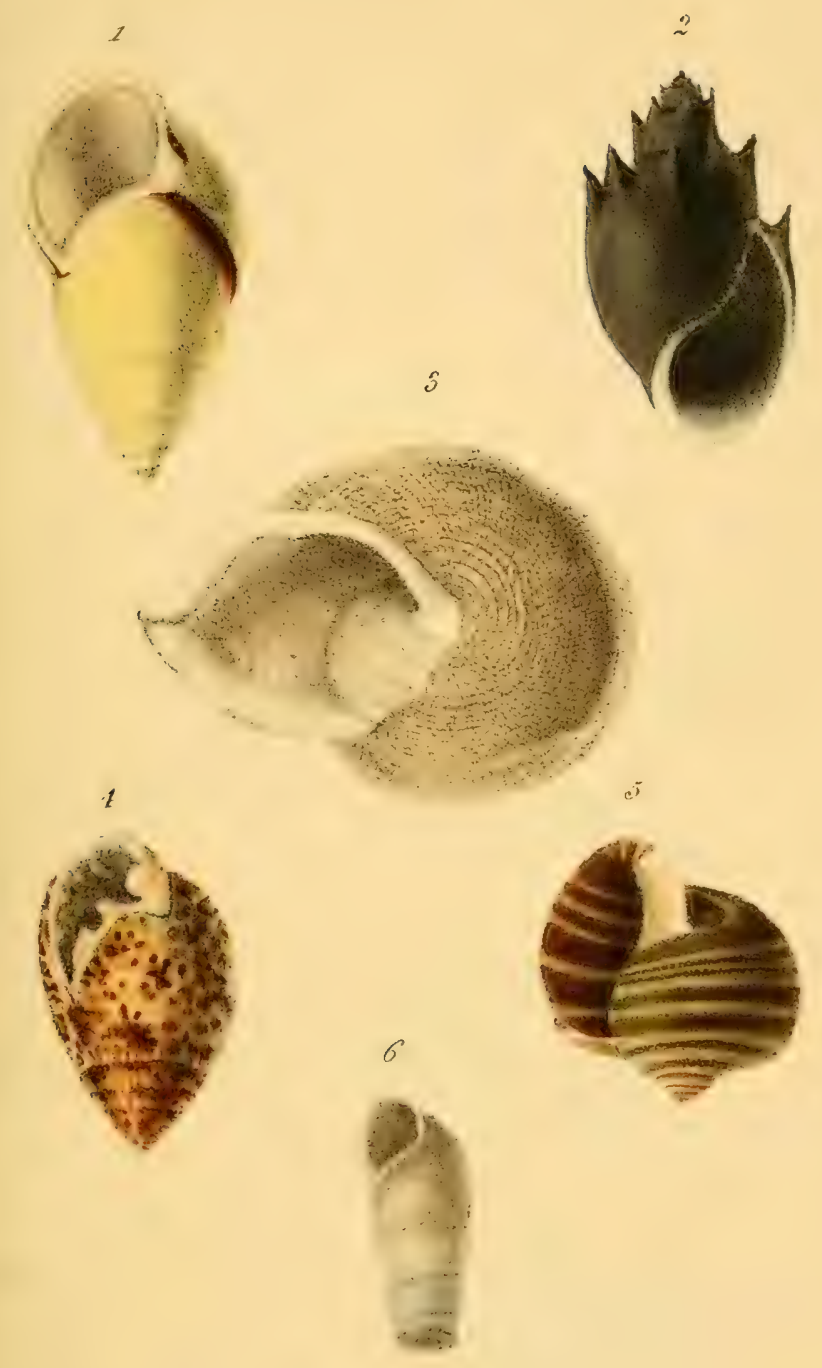

E.R. Crouch Lizhoo

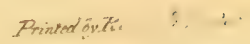

By.S. MIIIE 119 Strand. 



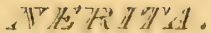

M.
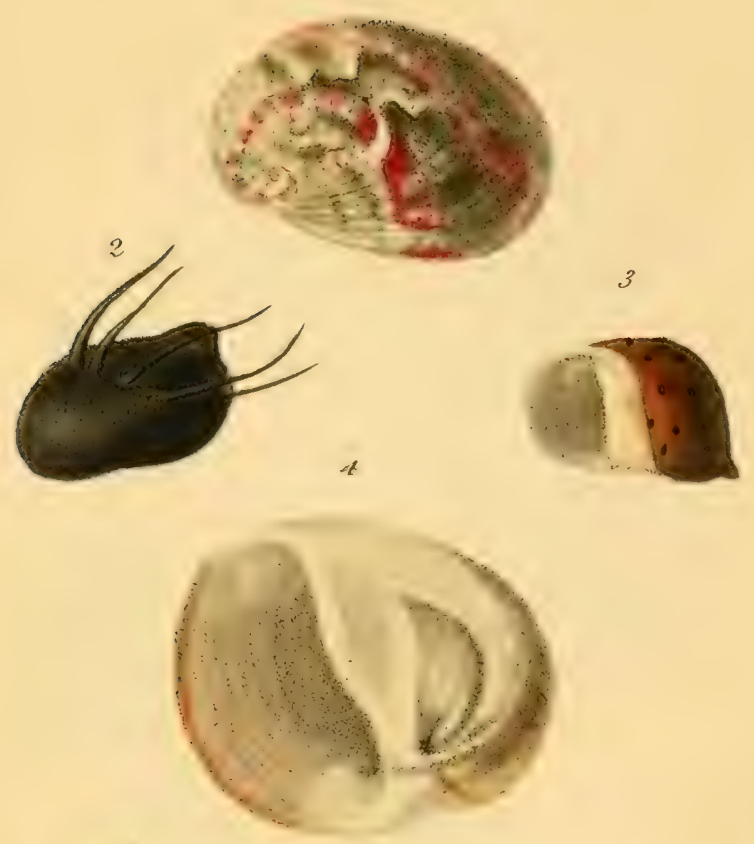

ก)
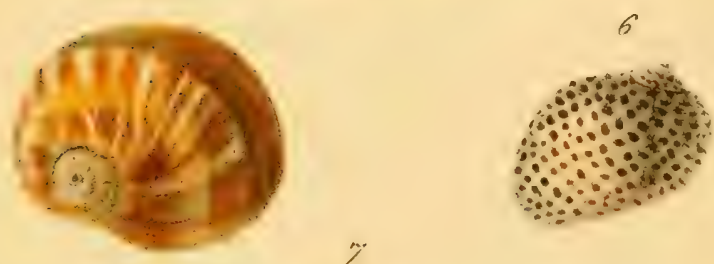

y

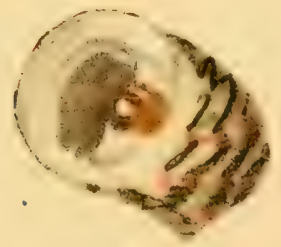

E. C. Cincechloth

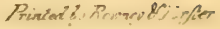
By J.MAIE, 14 S Strand? 

$P \%: \because \%$
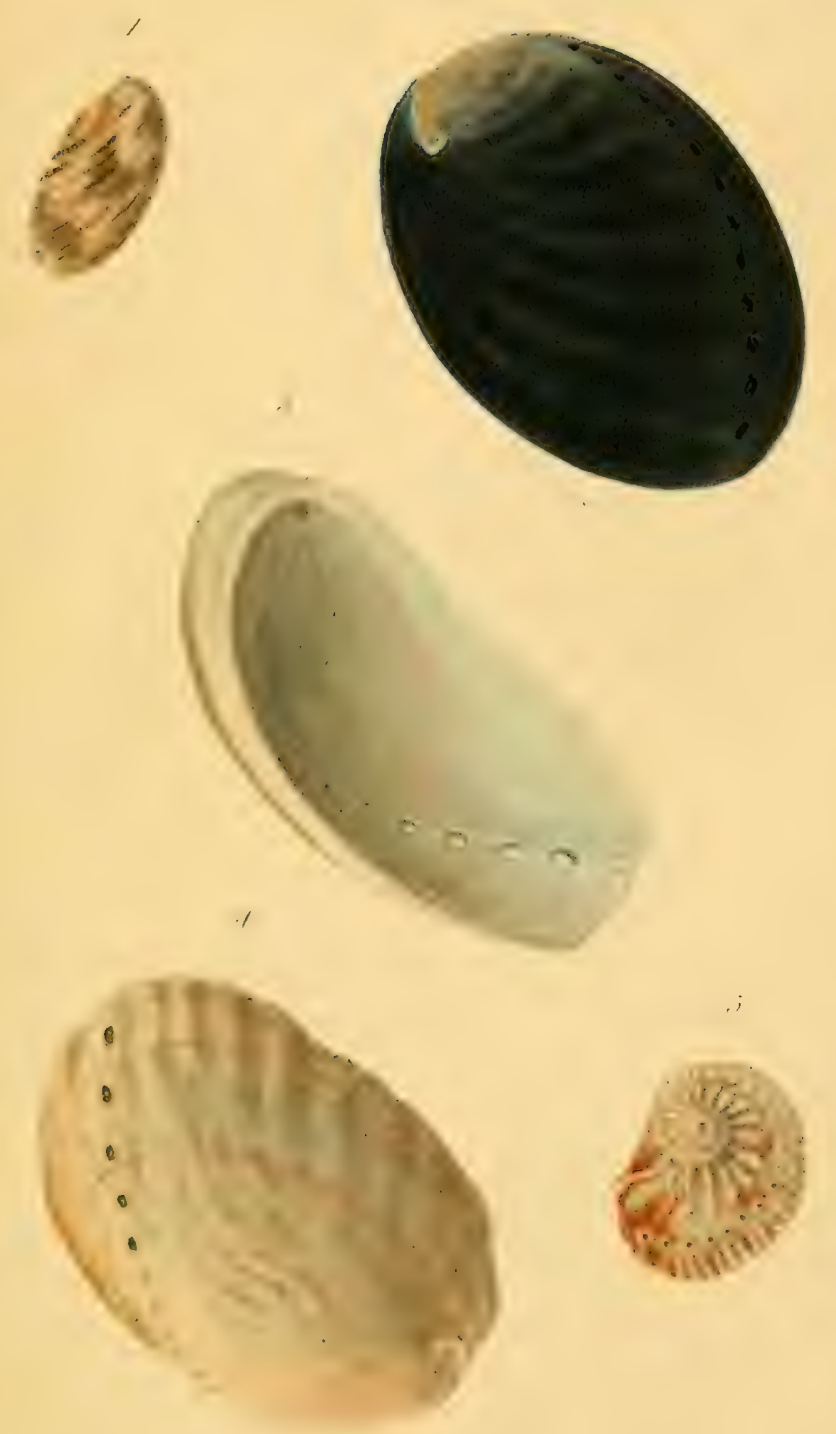

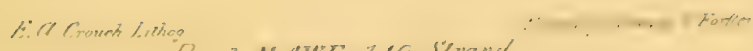

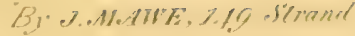



PU.32
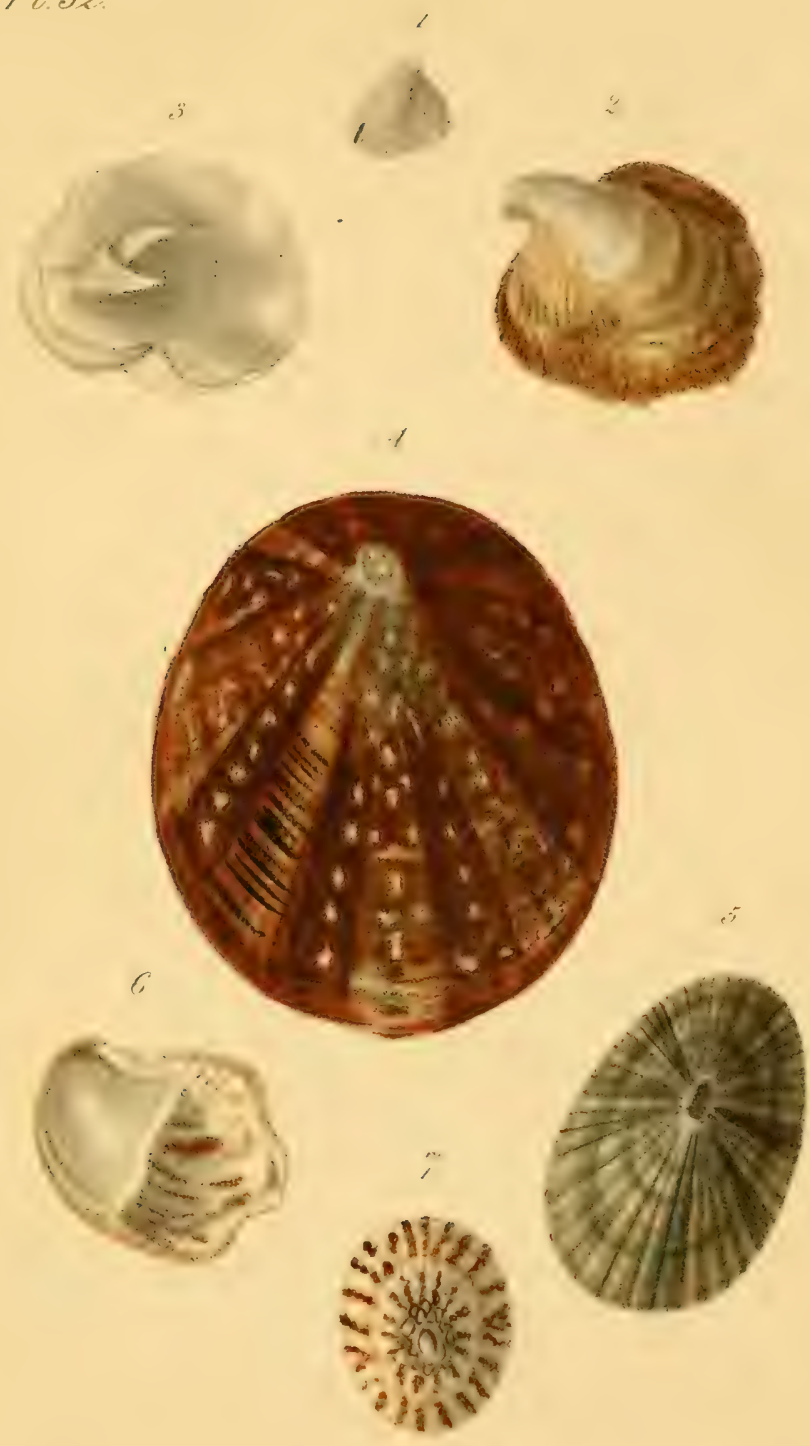

E. Cl. Croweh Lithog. 



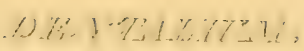

PI. .3.
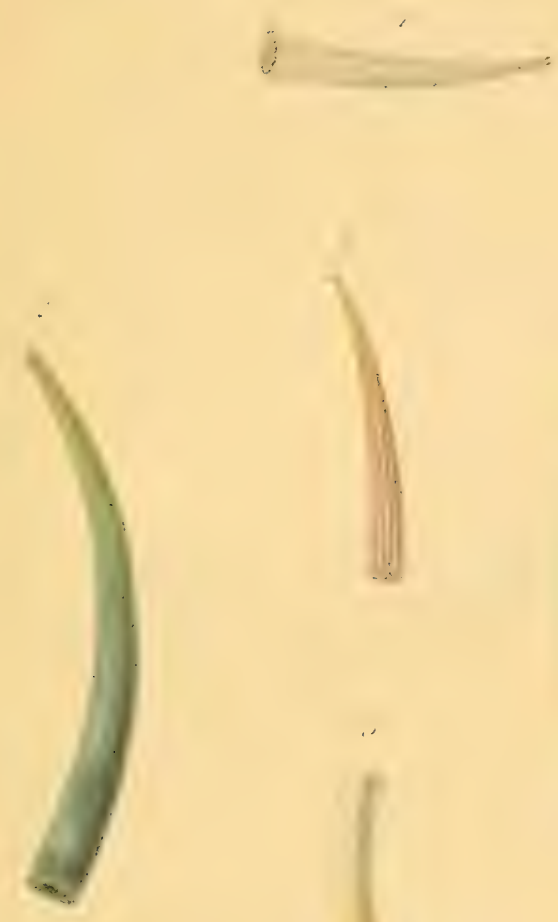

i

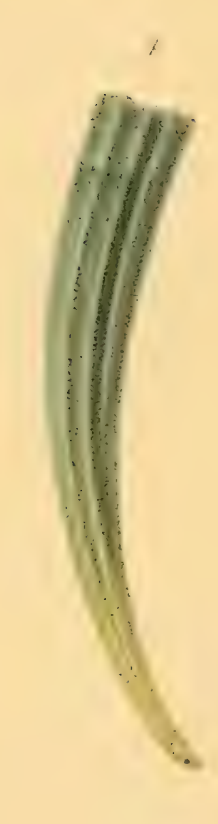

$\because$
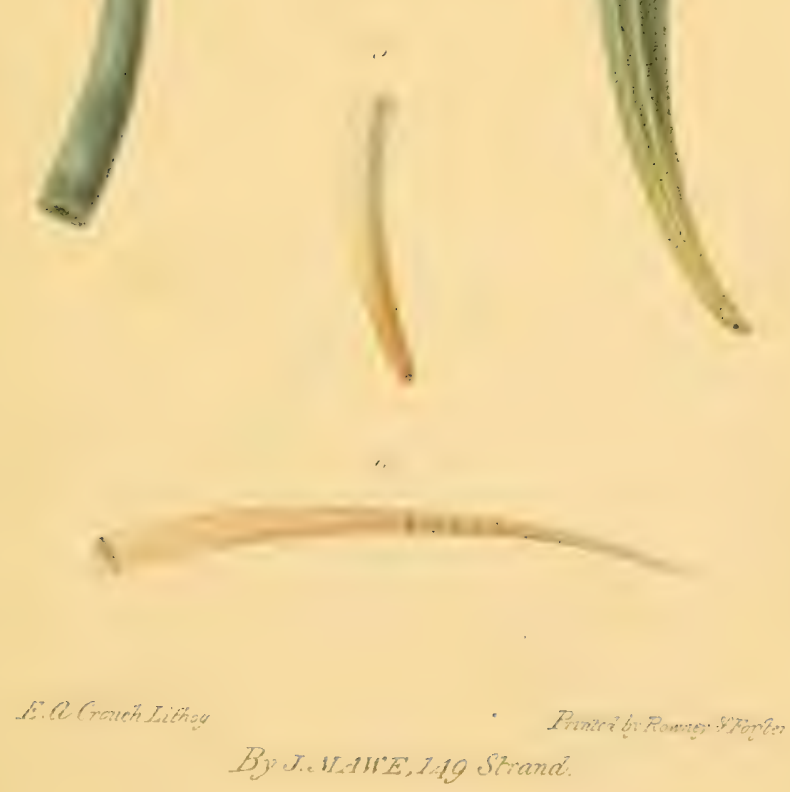



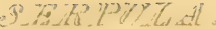
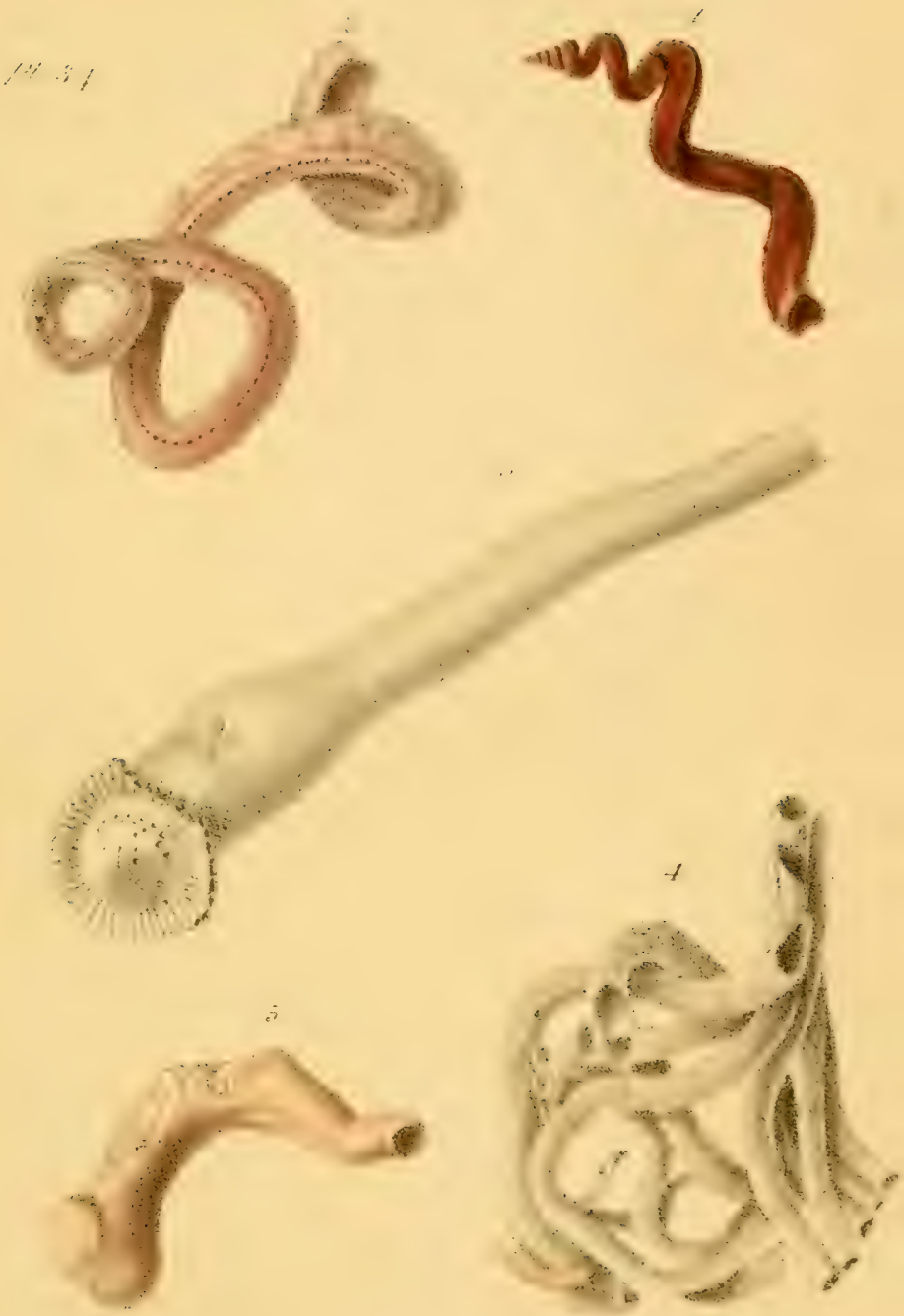

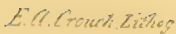

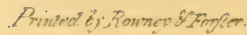
BY.T.11AHE 1.70 Sirand. 



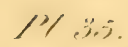
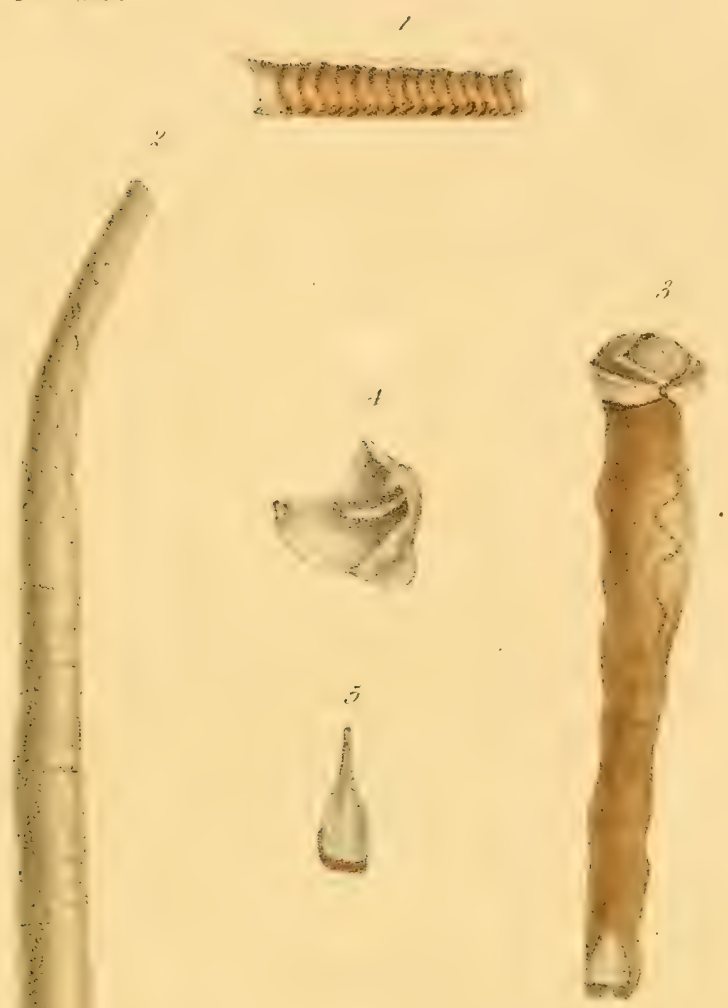

,

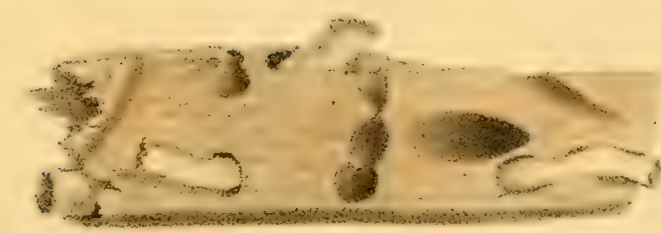



Pl. 36 .
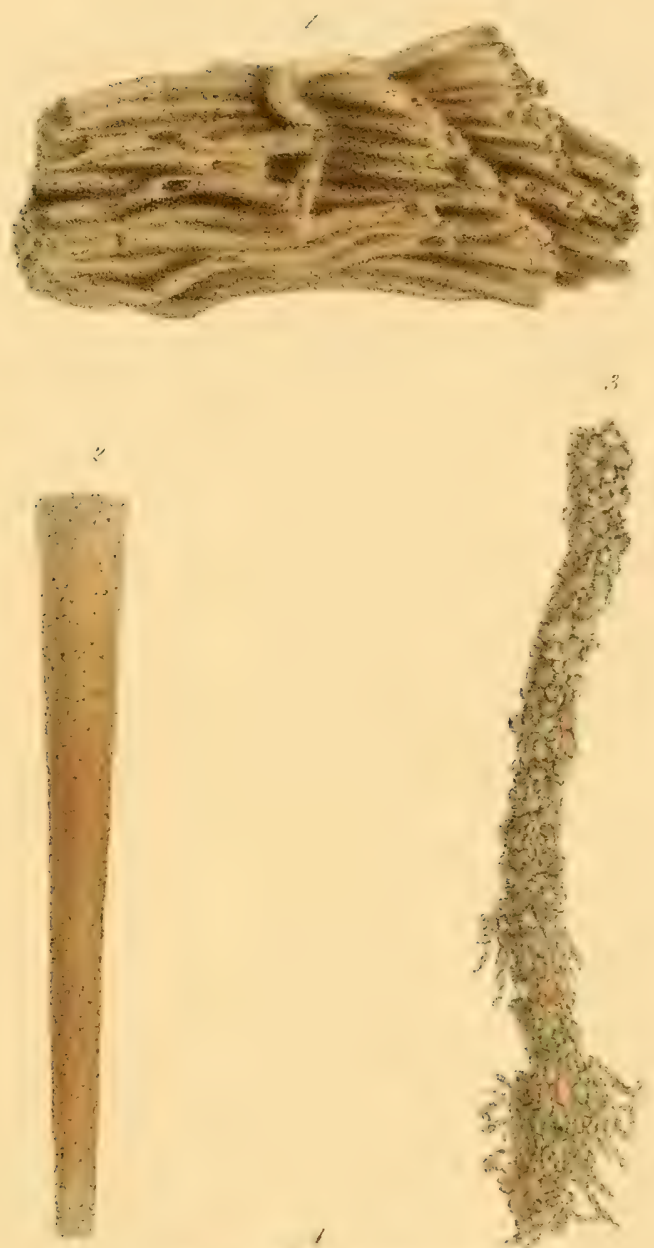

.3

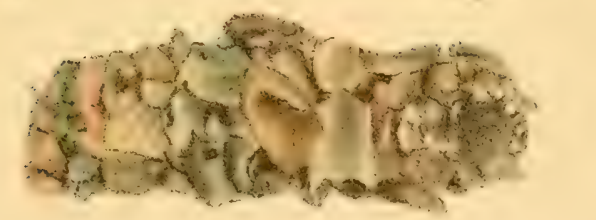








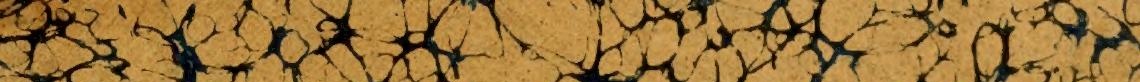

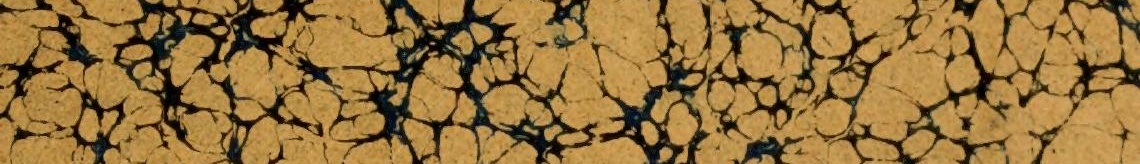

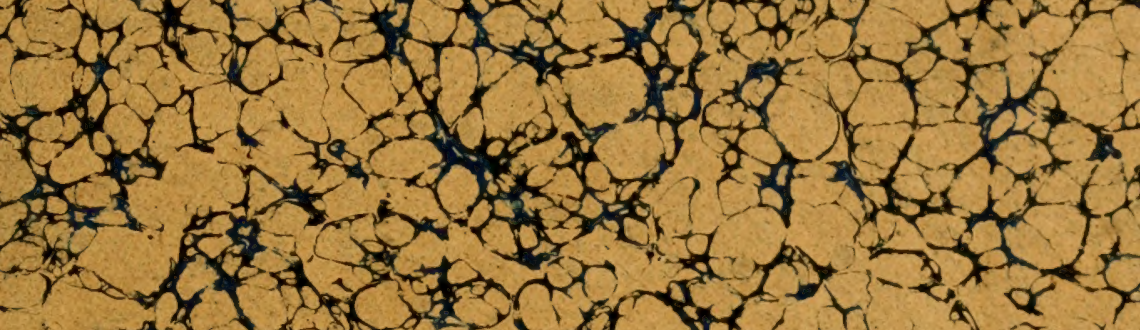

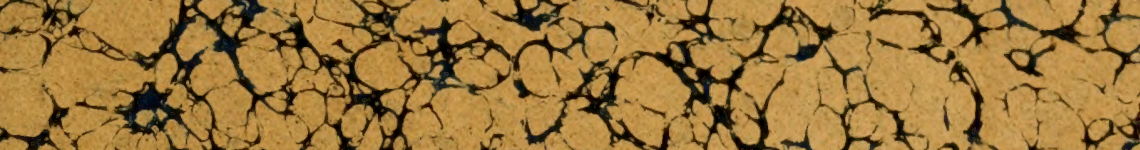

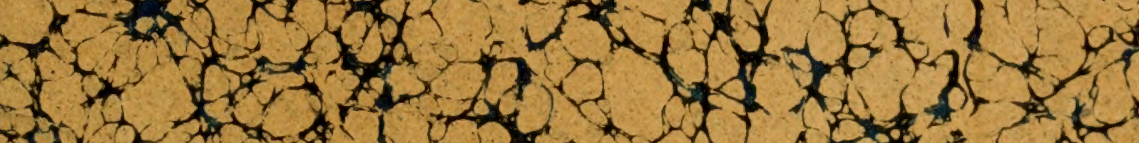
$30-3-1, x+1$

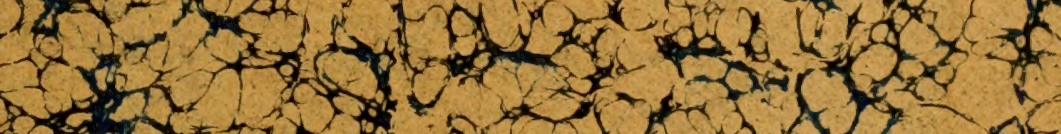

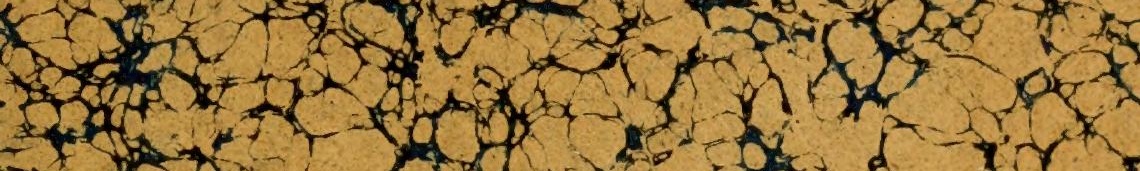

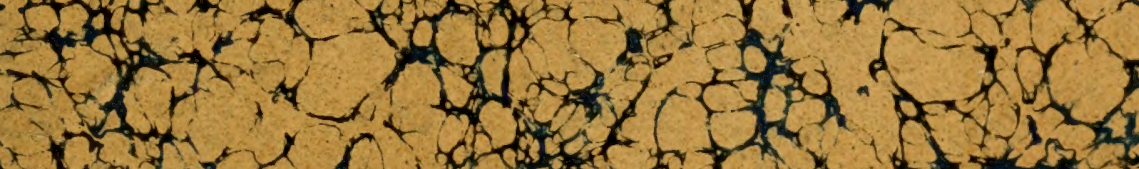

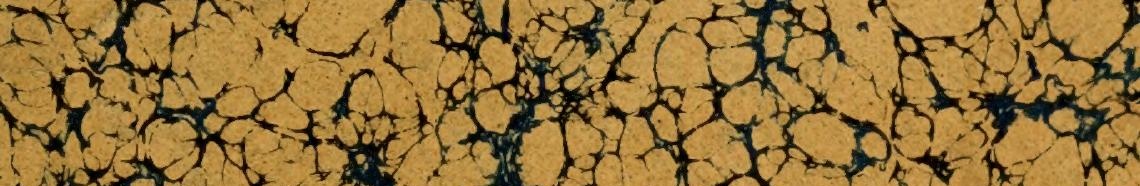

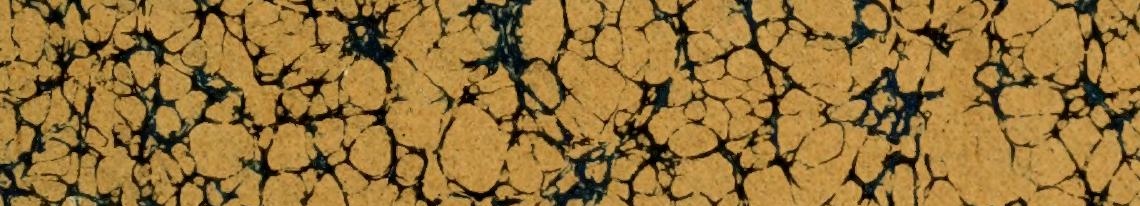
$3 \times(x+2+2+2 \times$

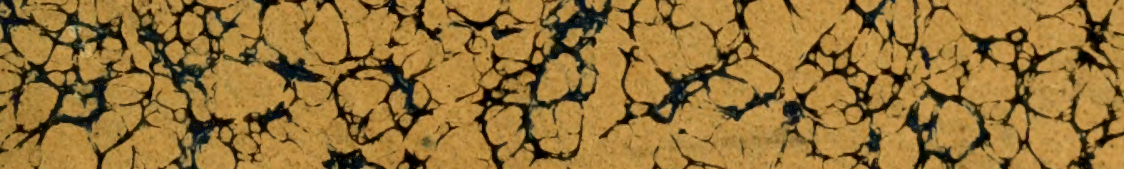

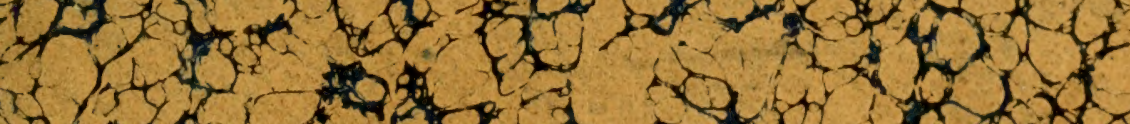

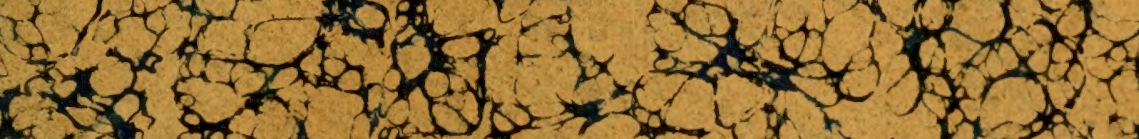

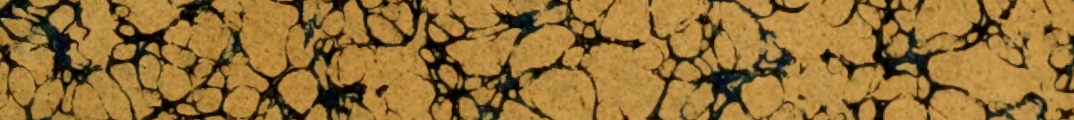

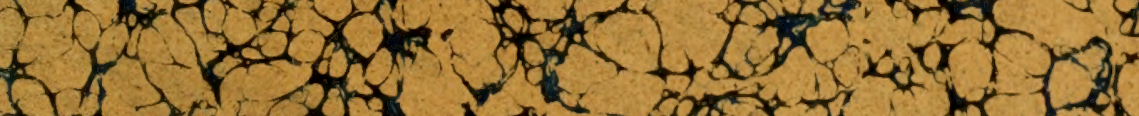
$x-6 x^{2}-3 x+2$

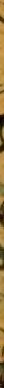




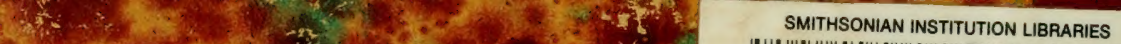

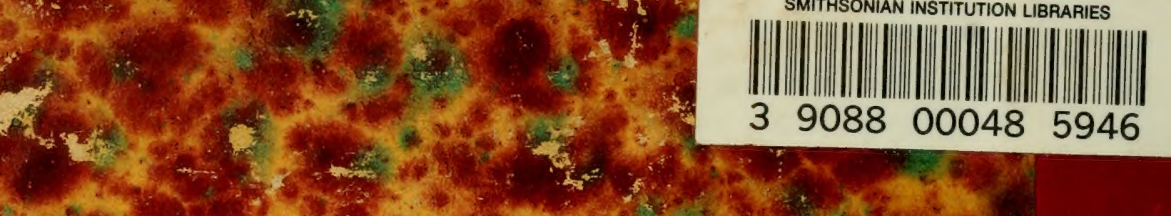

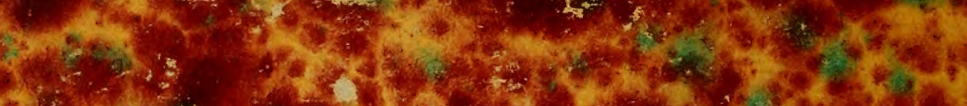
W. -

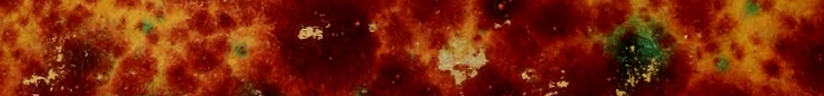

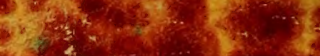

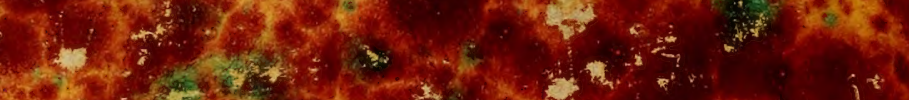

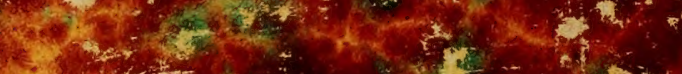

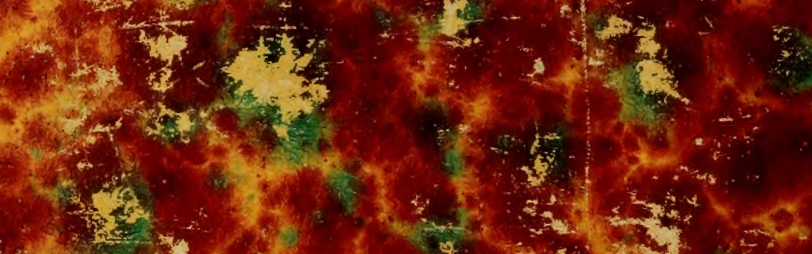

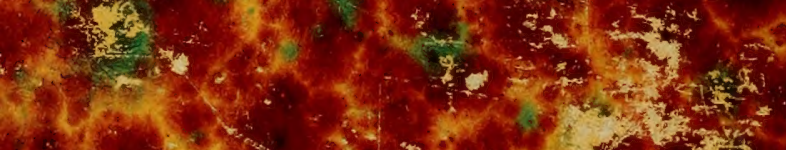

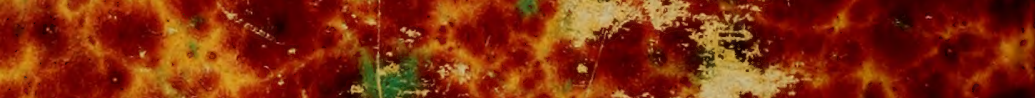

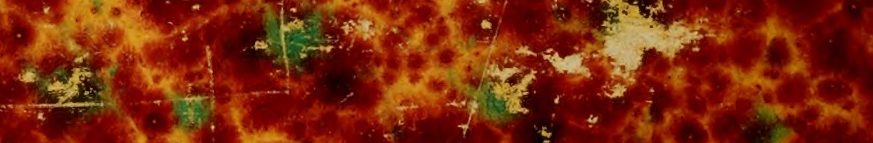

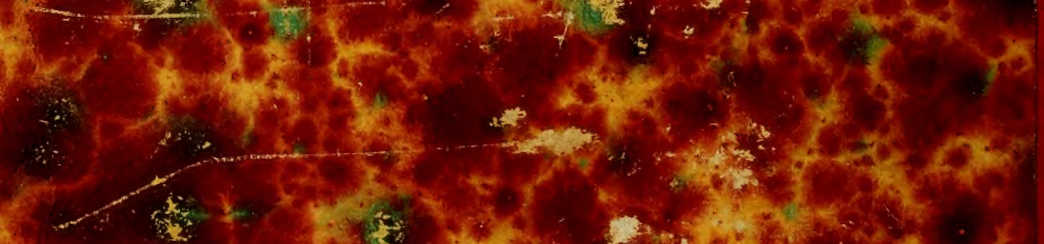
(2)

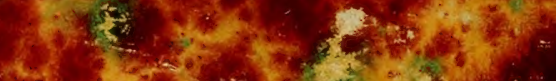
1. (a) $\therefore$ (5)

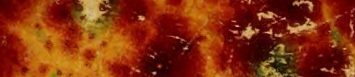

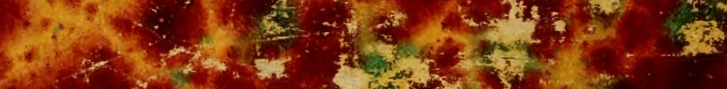

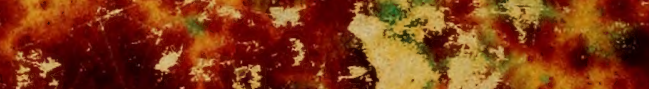

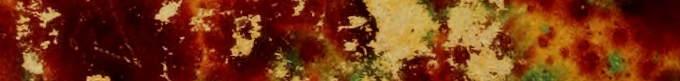
s.

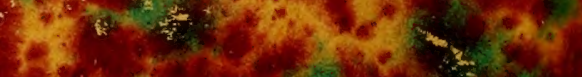

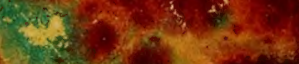

is H. $x^{4}$ A.

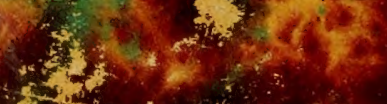

